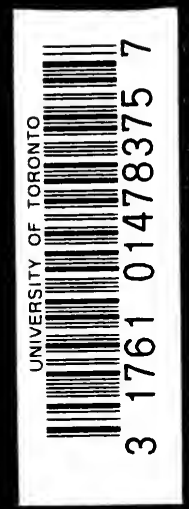



Digitized by the Internet Archive in 2007 with funding from Microsoft Corporation 


\section{DICTIONARY OF THE \\ HAUSA LANGUAGE}




\section{BY THE SAME AUTHOR}

A Dictionary of the Hausa Language. Vol. I. Hausa-English. Crown 8vo. 3rd ed. 12s. net. Vol. II. English-Hausa. Crown 8vo. 3rd ed. 10s. net. (Cambridge University Press.)

Specimens of Hausa Literature. Small 4to. 10s. Translation, Transliteration and Notes, without Facsimiles. 58. (Cambridge University Press.)

Hausa Grammar, with exercises, readings and vocabulary. 4th ed. 58. (Kegan Paul, Trübner \& Co.)

Magana Hausa. Hausa Stories and Fables collected by J. F. SchöN, D.D., re-edited by C. H. Robinson, D.D. - 2s. 6 d. (S.P.C.K.)

The Interpretation of the Character of Christ to non-Christian Races: an apology for Christian Missions. Seventh thousand. 2s.6d. In paper covers. 1s. (Longmans.)

The Missionary prospect, including a survey of Christian Missions in the past. 5s. net. (Partridge.) 


\section{DICTIONARY}

OF THE

\section{HAUSA LANGUAGE}

by

\section{CHARLES HENRY ROBINSON D.D.}

SOMETIME LECTURER IN HAUSA IN THE UNIVERSITY OF CAMBRIDGE HONORARY CANON OF RIPON

VOLUME II

ENGLISH-HAUSA

THIRD EDITION

Cambridge

at the University Press

I 9 I 4 


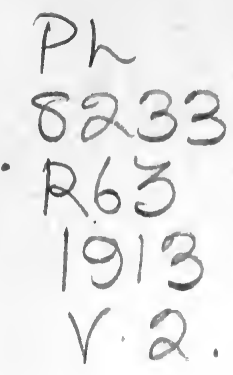

\section{$\frac{639295}{27.7 .56}$}

- CAMBRIDGE UNIVERSITY PRESS

C. F. CLAY, MANAGER

Zloñon: FETTER LANE, E.C.

edimburgh: 100 PRINCES STREET

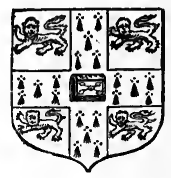

Berlin: A. ASHER AND CO.

Zeipzig: F. A. BROCKHAUS .

fetw gork: G. P. PUTNAM'S SONS

bombay and Calcutta: MACMILLAN AND CO., LTD.

Toronto: J. M. DENT AND SONS, LTD.

Tokngo: THE MARUZEN-KABUSHIKI-KAISHA

First Edition 1900

Second Edition 1907

Third Edition 1914

All rights reserved 


\section{PREFACE TO THE THIRD EDITION}

IN preparing this third edition of the English-Hausa 1 Dictionary for the press I desire to express my gratitude for much valuable assistance received from Major Frank Edgar, author of three volumes of Hausa stories (tatsuniyoyi), Mr W. J. Gowers, the Resident at Kano, Captain Roland Fletcher, author of Hausa Folklore, Dr Walter Miller, of the C.M.S. Mission, Zaria, the chief translator of the N.T. into Hausa, Dr J. M. Dalziel and others who have supplied corrections and additions to the former edition. To Major Edgar I am specially indebted for many suggestions in regard to the transliteration of Hausa words, and to Dr Dalziel I am indebted for much help in compiling lists of plants and animals.

The system of transliterating Hausa which has been adopted in this volume and in the fourth edition of the Hausa Grammar recently published, differs in several respects from that followed in Vol. I. The changes have been made in order to render the system of transliteration uniform with that which has recently been adopted by the English Government authorities in Nigeria. It is impossible by any system of transliteration to represent the exact sounds of many Hausa words. Thus we might almost equally well write yanka or yenka ' to cut,' kwai or kwoi ' egg,' hanya or hainya 'road,' bakwai or bokkoi 'seven.' In each case the sound to 
be represented lies between the sounds suggested by the alternative forms. The Hausa script affords no help in deciding between $e$ and $a$ in a word such as yanka ' to cut,' as the script contains no symboll for a short $e$. In order to bring the system adopted in this dictionary into line with that of the books issued by the Government of Nigeria I have adopted the former alternative in each of these cases which are typical of many others.

Several changes have also been made in respect of the divisions between nouns or pronouns and prepositions. Prepositions will be found written as separate words except in cases where the words to which they are attached cannot be used as independent words apart from the prepositions. 'Thus we have ma shi or masa 'to him.' The possessive pronouns are joined to the nouns to which they belong. In some cases, e.g. wurinsa ' in his place,' where the pronoun is really possessive the noun although used as a preposition cannot be separated from the pronoun: the same rule would apply to a use such as ina binsa 'I follow him.' In a few cases a preposition followed by a noun has become so closely united that it would be pedantic to separate them, e.g. dayawa, cf. English 'forasmuch,' 'overmuch' etc.

There are many instances in which it is impossible to say whether a double consonant should be used for purposes of transliteration. In the former edition of this dictionary in such doubtful cases the second consonant was placed in a bracket, e.g. $\operatorname{dag}(g) a$ 'from.' As this method of transliteration is clumsy and is otherwise unsatisfactory the use of brackets has been abandoned. In a considerable number 
of cases a word may be written either with a single or a double consonant. Thus we may write dăga or dagga, tăfi or taffi 'to go,' bisa or bissa 'top." The general rule is that wherever a consonant is doubled both consonants should be pronounced: thus amma 'but,' should to pronounced am-ma.

In accordance with the use adopted by the majority of Hausa students I have avoided the use of chch, shsh and tsts, as, although in a word such as chikache 'full,' the sound chikachche may be heard when the word is pronounced with unusual deliberation, the double $c h$ is not heard when the word is used in ordinary rapid conversation.

As this dictionary is intended for the use of those who desire to speak the ordinary colloquial Hausa, I have omitted rare words and rare plurals or other formations.

June, 1914.

\section{CHARLES H. ROBINSON.}




\section{ABBREVIATIONS}

\begin{tabular}{ll|ll} 
ans. & answer. & neut. & neuter. \\
art. & article. & obj. & objective. \\
coll. & collective. & part. & participle. \\
comp. & comparative. & pass. & passive. \\
concr. & concrete. & pers. & person. \\
conn. & connective. & phys. & physically. \\
dem. & demonstrative. & possess. & possessive. \\
diff. & different. & pregn. & in a pregnant sense. \\
expr. & expression, also=ex. & prep. & preposition. \\
& pressed. & pr. $n$. & proper noun. \\
fem. & feminine. & pron. & pronoun. \\
fig. & figuratively. & rel. & relative. \\
foll. & following. & rep. & repeated. \\
fut. & future. & sep. & separate. \\
gent. & gentilic. & spec. & specially, also=special, \\
id. & the same. & & special term or terms. \\
impers. & impersonal. & suff. & suffixed. \\
instr. & instrumental. & techn. & technical. \\
interj. & interjection. & tr. & transitive. \\
interrog. & interrogative. & trop. & tropically. \\
intr. & intransitive. & v. & verb, also=see. \\
loc. & of place. & verbs. \\
neg. & negative. & & \\
& & &
\end{tabular}

The letters (K.), (S.) or (Z.) placed after a Hausa word denote that the word is specially used in the districts of Kano, Sokoto or Zaria. 


\section{ENGLISH-HAUSA DICTIONARY}

When more than one Hausa equivalent is given it is not intended to suggest that the Hausa renderings are synonyms. For the exact meanings of the Hausa vords the student is referred to the HAUSAENGLISH Dictionary.

Words to which * is attached are not in general use amongst the Hausas, and should not be employed without reference to the HAUSA-ENGLISH Dictionary.

a, 1. indef. art.; there is no word generally used in Hausa corresponding to the English indefinite article, the simple noun sufficing, e.g. $b a$ ni goro give me a kola nut.

2. as indef. pron. taking the place of an art., daya one and wani, fem. wata, pl. wansu, vasu or wadlansu are sometimes used, e.g. wani gari ke nan there was a city, akwai wata mache sunanta Amina there was a (certain) woman named Amina.

3. a-, found as a prep. prefix with Engl. words, as ashore $a, d a$, e.g. afoot $a$ kafa, alive da rai.

aback, 1. adv., see back.

2. fig. e.g. I was taken aback (i.e. I was staggered or surprised) at this wannan ya ba ni mamaki. abandon, tr. v. bari, bar.

abandoned, adj., see profligate.

abase, tr. v. maida or yin lkarami ; refl. with kai (= self), e.g. he abases, or humbles, himself ya maida kansa $k a$ rami, or ya tankwasa kansa. abash, tr. v. $s a, b a$ or $b a d a$ kumya; I feel abashed na ji kumya (or kunya).

abate, tr. v. raga, rage, ragi; intr. ragu, ragi.

abatement, n. (decrease) räge$w a$, raguwa; = amount deducted from price of anything rangwame, grant me an a. ka yi ma ni rangwame. abattoir, n. wurin fawa. abdicate, intr. v. (used of a king) kawu, maida rawani. abdomen, n. chiki; jiki, pl. jikuna (lit. body) is sometimes employed in this sense. 
abhor, see hate.

abide, intr. v. (dwell) zamna ; see abode.

ability, n. 1. (power) iyawa, $i k o$, a. to do what one likes samun dama.

2. (mental power, understanding) cf. hankali, dubara, dabara, dibara, lura, wayo.

abject, adj., see despised. able, to be, v. iya, $i m a$, isa, e.g. I am a. to do this work ina iya yin aikin nan, you can do this $k u$ isa yin wannan, or ku isa ku yi wannan; to be unable or not able is expr. by gaza, or the neg. of the above, e.g. we are unable to lift this $b a$ mu isa mu dauka wannan ba, I cannot na gaza or ya faskare ni (lit. it surpasses me).

able, (clever) gwani.

ablutions, ceremonial, n. alwalla, arwalla; a. made with sand taimama; to make a. shafe, shafo.

abode, n. mazamni, gǐda.

abolish, tr. v., see take away, destroy.

abominable, adj. mugu, fem. mugunya, pl. miyagu, or mugaye.

abominate, tr. v., see hate.

abomination, n. abin mugu, abin ķazamta, abin haram. aborigines, n. habe.

abortion, ashara, to produce

a. bata chiki, yasda diya.

abortive, adj. babu anfani, banza.

abound, intr. v. faye, ķāru, yin girma; see abundance, abundant.

about, adv. and prep. 1. (a. so much, nearly) ko, kwatamchin (kwatanchin, kăza).

2. (around) kewaye; a. him kewayensa.

about, to be, v. $z a$ followed by the personal pronouns, e.g. I am a. to start $z a$ ni tashi; yin kŭsa, kŭsata, e.g. su kŭssata in yi haka; cf. makāda. above, adv. and prep. b̌sa, a b̆sa, dăga b̌̌sa, birbishe (S.), darap ; as prep. b̌sa ga, and, when followed by personal pronouns, gare, e.g. b̌sa ga tudu but b̆sa gare shi; cf. biz-biz.

abreast, adv. ajere, ajera, gaba daya, dabara, daura.

abroad, adv. a waje, daga waje; (at a distance) daga nesa.

abrogate, tr. v. kauda, kawas $d a$; to a. a law gushe. abrupt, adj. (precipitous) $d a$ gangara.

abruptly, adv. (suddenly) $d a$ sauri, da samri. 
abscess, n. kurji, ḳureji, ḳirchi, gurje, pl. kuraje, maruru, gyambo, pl. gyambuna, hantukuriya (K.), jambade.

absence, in his bayansa. absent, see under present. absorb, tr. v. sha, shanya; (used of cloth, etc.) tsotsa; to be absorbed in thought or business (so as to forget all else) yin shagalchi, e.g. I was so absorbed that I forgot this na yi shagalchi har na manta wannan.

abstain from, tr. v. daina, denc; bari, bar.

abstract, tr. v. debe, fitasda; (to purloin) sache, sata, yin sata.

absurd, adj. banza.

Abubekr, pr. n. Abubakar, also contracted form Bube.

abundance, n. yava, yawanchi, auki*, yalwa, yayalwachi, kāri, malala, rufogo, walcuwa, tululu, tilli, tulli, rikumbu*; (a. of food) zari, machiya, tinjim*.

abundant, adj. dayawa, mayawa, mai-yawa.

abundantly, yālwache.

abuse, n. (i.e. abusive words) habaichi, pl. habaitai, kazaf, kazap, zambo.

abuse, tr. v. 1. (to revile) zage, zagi, birga, burga; (to a. behind one's back) yin habaichi, chim baya.

2. (to make ill use of) turn by yin with abin wofi, etc.

acacia, bagarıwa, gabaruwa, dakwara, dushe, fura kaya, farchin shafo, gaba chara, gardayi, gawo, pl. gawake, kwarkwara, karkara, kakkara, kwandariya.

accede to, v. 1. yarda, e.g. abin nan da ya fada ma ka mun $y a r d a=$ we a. to the terms he mentioned to you ; amsa.

2. (as heir) gāada.

3. (to the throne) chin sarauta, chi, yin sariki.

accelerate, to hamzarta, see hasten.

accent, he has an a. bakinshi yana da kwata.

accept, tr. v. karḅa, karḅi, samu; cf. also prec. 1.

acceptable, adj., it is a. to me, periphr. ya gamshe ni, da or abin da ya gamshe ni.

acceptance (receipt), amsa. accident, n. kure, pl. kurakuri, subăbi, tsautsayi; an a. happened to him sabăbi yc same shi.

acclamation, n. guda. See shout.

accompany, tr. v. raka, răki, 
rake, yin rakiya, chi $m a$, I will a. thee $z a$ ni tare da kai.

accompanying, act of, $\mathbf{n}$. rakiya (S.), rako (K.).

accomplish, v. iyas, iyas da, kare, chika, gama, yi.

accomplished, particip., see finished.

accord, to a. with yin baki daya, yin kăma da.

according as, adv. particle

kăma da, kqman da, kanda, tamkan da, tamkar da, tamkad $d a$, yadda.

accordingly, see therefore. accouchement, jego.

account, n. 1. lisafi, lesafi, kidaya, kida, kididiga; to render an a. yin lisafi, yin kidaya, to take a. of $z \tilde{a} n a$.

2. fig. e.g. he held of no a. ba ya kula or ba ya yi kula constr. with $d a$ or ga.

3. (narration) labari, to give an a. bada, ba or gaya labari; I will give you an a. of the war zan gaya ma $k a$ labarin yaki.

account, on a. of, prep. săba $d a$, săbad $d a, s a \breve{b o} d a *$, a b̌sa, don, domin, e.g. on a. of this săbad da wannan, on a. of what? wherefore? don mi, dommi, or domi. accoutred, one who is a. mai-daurin jiki.

accoutrements, i.e. arms, etc. kayan dāga, kayan yaki.

accrue, v. 1. (of gain) see profit.

2. (happen, ensue) faru. accumulate, see gather. accurate, adj. and adv. $n a-$ kwarai, fem. ta-kwwarai, daidai, sosai; to be a. yin daidai.

accursed, adj., e.g. it is accursed ya yi la'ana.

accusation, n. sara, abin sara, rada*, kāra; false a. rinto, kage.

accuse, v. sare, sara, kai kă̄ra (lit. bring an accusation, constr. with $g a$ ), e.g. they a. this man sun kai ḷära ga mutumen nan, l̦aga ma*.

accuser, n. mai-sara, pl. masusara, mai-kawon kâiva, dankara, mai-ḳara.

accustom, v. 1. to be accustomed saba, e.g. I am accustomed to this na saba da wannan, domestic animals are accustomed to men, bisashen gida sun saba da mutane.

2. (to be wont, used) employ the verbal form with $k a n$, e.g. he was accustomed to do thus shi kan yi haka. 
3. tr. I accustomed him to this food na sa shi shi saba da abinchin nan.

ache, n. chiwo ; I have a headache na ji (or na yi) chiwon kai.

achieve, v. aikata, samo*, yi, see accomplish.

acid, adj. da tsami, da tsamiya, da yami.

acidity, n. tsami, tsamiya, yami.

acknowledge, see confess.

acquaint, tr. v.(i.e. tell, inform

of) gaya, fadi, sanas da, sanan da, sanar da, sanashe.

acquaintance, an, n. masani, pl. masana; he is no a. of mine, I am not acquainted with him ba shi ne masanina ban san shi ba.

acquainted with, 1. see prec.

2 . (versed in); see accustom 1.

acquiesce, v. yarda; I a. in this na yarda wannan.

acquiescence, yarji.

acquit, v. (used of a judge) chechi, bada gaskiya; to be - acquitted barra, kubuta.

acrid, see acid.

acrobat, dan foto.

across, prep. 1. e.g. a. the sea ketaren (or daga ketaren) gulbi.

2. (beyond) bayan. act, n. aiki; phr. a bad a. mugunta, mugun aiki; a good or kind a. alheri.

act, to aikata, yi.

active, karsani*.

actually, adv. hakika, da gaskiya, ko ; the last is emphatic (=even), e.g. this man a. surpasses a lion in strength mutumen nan ya $f i$ ko zaki karifi.

Adansonia digitata (the baobab or monkey-bread tree), kuka.

add, tr. v. ḳāra, jimilla.

adder, putf-a. kasa.

addicted, to be a. to faye, e.g. the boys are a. to (or fond of) play yara suna faye yin wargi.

addition, in a. to bam da, ban $d a$.

address, to a. to, v. ambata, ambache.

adduce, tr. v., e.g. to a. testimony kai (or kawo) shaida.

adept, n. gwani, pl. gwanaye ; he is an a. at... shi ne gwani $n a . .$. ; also ya saba $d a .$. adhere, to a. to, v. rike, dafe, like, lazumche, lazumta, nana, nane, the last is used of things stuck together with gum etc.; those who a. to the commandments of God 
masu-riken hakumtai na Allah.

adhering, n. nani.

adhesive, adj. mai-yauki.

adieu, interj. sai wata rana;

a. for the present sai an jima,

a. till to-morrow sai gobe.

adjoin, intr.v. kusata, kusanta, kusache, yin kusa.

adjure, v., I a. thee by God na gama ka da Allah.

administer, tr. v. (to give to, e.g. medicine) $b a, b a d a$; to a. justice or law yin shari' $a$; to a. government, cf. mallaka, hakumta; an administrator of law and justice maraban shari'a da gaskiya.

admit, tr. v. 1. I admitted him, periph. na bav shi shi shiga.

2. to a., e.g. error, guilt etc., see confess.

admonish, see warn.

adoption, n. yanchi.

adoptive, a.-father uban rana. adorn, tr. v. gyarta.

adorned, adj. gyartache, fem. gyartata, pl. gyartattu.

adornment, n. sha'awa, ado, the last used of trinkets, etc., also of dress.

adulteration, algus, algusu, tsirariya, tsinariya, hä̈nchi. adulterer, n. kwarto, fem. kwartuwa, mazinachi, mazinanchi, mai-zina. adulteress, n. mazinachiya, mazinanchiya, farka, falka, fasika.

adultery, n. zina, kwartonchi, $z a m b a^{*}$.

advance, intr. v. yin găba, to get in a. of chin găba, riga, rigaya, rigayi, e.g. he outran us ya riga mu.

advantage, n. anfani; of no a. babu anfani.

advantageous, adj. da anfani, mai-anfani.

adversary, n. makiyi, pl. makiya, abokin-gaba, mai-kin-ji. advice, n. dabara, dubara, dibara (S.), shawara, my a. is abin da na gani.

advisable, adj. see advantageous.

advise, v. yin dabara.

advocate, n. (helper, defender) mai-taimako.

afar, adv. nesa, dăga nesa, e.g.

I saw him from a. na hange shi dăga nesa.

affair, n.abu, abin, pl. abubuwa, sha'ani, shăgali, e.g. a sad a. mugun abu, abin mugu; avoid deceit and falsehood in your affairs a bar (or bari) tsalumchi da kariya ga abubuwanka; al'amari, e.g. a wonderful affair al'amaringa; the affairs (=the vicissitudes or changes) of this world 
al'amarin duniya; zamanchi, zama(i.e. condition of affairs), e.g. how are affairs with you in the city? ina zaman gari? ans. we have reason to be thankful for the condition of affairs zaman gari da godiya. affect, to săbe; the heat of the fire affected her wuta ta săbe ta.

affection, see love.

affinity, (by marriage) surkunta.

afflict, tr. v. yin wahala. afflicted, adj. (one who endures affliction and toil) mai-wahala, pl. masu-wahala.

affliction, n. wahala, masība, matsuwa, see pain.

affright, 1. n. tsoro.

2. tr. v. bada tsoro, tsorata. afoot, adv. a kafa, da ḳafa. afraid, adj. I am a. na tunzera, or na firgita; he made him a. ya ba shi tsoro; to be a. jin tsoro.

afresh, adv., see again. after, 1. prep. baya, bayan, baya ga.

2. adj. na-baya, fem. tabaya.

afternoon, n. la'asar, see under rana.

afterwards, adv. (after this) bayan wannan, bayan haka. again, kuma, haryo, har yau, na sābo, dăda, dai, de; the v. kara (add), e.g. I did not do so a. ban kara yin hăka; a and a. (i.e. repeatedly) maimaiche; go again $k a$ sake tafiya.

against, prep. gaba ga, ga; to stumble a. tuntube da; a. his will (perforce) da tilas. agate, a brooch of talhatina. age, n. 1. (period or time) yayi, e.g. in the a. of the prophet da yayin annabi.

2. (time that a person has lived) shekarce or pl. shekaru, e.g. what is your a.? shekarunka nawa? or shekara nawa kana da rai? or shekara nawa tun haifuwarka? I am eighteen years of a. shekarata ishirin biyu babu.

aged, adj. 1. (of a certain age), see prec. 2.

2. (advanced in years) tsofo, fem. tsofuwa, pl. tsoffi, tsofaffi, or tsofoffi; he is a. yayinsa ya wuche, lit. his time is past; see old.

agent, n. naïbi*; nouns denoting the a. may be formed from verbs, substantives or adjectives by prefixing mai or $m a$, e.g. gudu to run, mai-gudu a fugitive, sassaka to smooth wood, masassaki a carpenter; for further 
illustrations see under mai and $m a$.

aggressor, to be an harzuka. agitate, tr. v., see shake.

ago, adv. tun, tun $d a$, e.g. this was written twelve days a. kucana sha biyu tun da wannan an rubuta shi; long a. da, lokachin da, tun dadewa, da wuri, dauri, tuntuni. See age 2.

agree, v. gama, gamu, yardā, yarje, yin baki daya, sādu, jǐto, jèto, damre magana ; my friend and I a. exactly da ni da abokina mu ne tangas; he agreed with you ya yarda ma ka; agreed to yardadide.

agreeable, adj. 1. (pleasant) da dadi, dadi, daidai, dede.

2. (willing), e.g. if you are a. in (or idan) ka yarda, in ka (or kana) so.

agreement, n. sulhu, sulfu, sulba*, yardi, yarji ; a trade a. sallama; to make an a., see agree; a. to work for a certain sum sharadi.

ague, n., see fever.

ahead, adv. gaba.

aid, tr. v. taya, yin taimako, tanya, tanyo, koro sauki.

aid, n. taimako, taimakawa, sauki; (a helper) mai-taimako. ail, v., e.g. what ails you? mi ya same ka?

ailment, n., see sickness.

aim, (point aimed at) bara; to aim at, yin bara, barata, barache, bartaka, nīna, nūno. aimless, a. toil aikin banza. ainhum, n., i.e. a disease of the little toe, hambudiga, mageduwa; cf. also kudumbiya a disease which may affect all the toes.

air, n. iska, hiska; shan iska is the Hausa idiom for to take a walk, e.g. let us take a walk to enjoy the air mu yi yawo garin shan iska. air, v. kekashe, see to dry. ajar, to put a door a. saya kofa. akimbo, put your arms a. chi dununka da hannu.

alarm, to yin ruba, see frighten.

alarm, n. yagatu (K.).

alas, interj. kaito, (S.) kaicho,

(K.) kaitaro, wai, wai niya, tir, ashsha.

albino, n. zabiya.

alien, n. bare ${ }^{*}$; see also stranger.

alienate, to a. a person kangara $d a$.

alight, intr. v. sabka, safka, sapka, sauka, soka, sabki, sapki, shida, shide, jīda.

alike, adj. daidai, suwa-suwa, 
tangam, tangas, sakke (S.); they are all a. duka laya ne, suparsu (or sifassu) laya, or sun yi tangam da juna.

alive, adj. da rai; to keep a. raya, e.g. may God preserve us a. Allah shi raya mu.

all, adj. duka, duk, dukanta, jama'a; a. together tarsashi, tararre, fem. tararra, pl. tararru; a. of you dukanku, tarinku; a. men mutane duka or dukan mutane; all (i.e. total) dokachi; all (i.e. everything) dokachin komi.

Allah, by wallah, wallahi

allay, tr.v. futas da, kwantas da. allegory, n. misali, michali*, almara.

alliance, n. găya.

alligator, n. kăda, kădo, pl. kădōdi, kaduna, or kadunduna. allow, tr. v. bari, bar, yarda ; e.g. let me depart bar ni in tafi, if you a. we will do so in ka yarda za mu yi hăka, a. me $b a$ ni yarji.

alloy, n. haïnchi; unalloyed babu hä̈nchi, safi.

allure, tr. v. rude.

almighty, adj. mai-iko da kowa, mai-iyawa.

almond, n. chanza*.

almost, adv. kŭsa; it is a. finished ya yi kŭsan kare or ya kŭsa ḳarewa. alms, n. sadaka, zakka, kurdin gurasa, kono* (K.), almsgiving, n. sadaka.

aloe, (Aloe zebrina) zabo.

alone, .adv. kadai, kawai, abin followed by a personal pronoun, thus, he a. abinshi, I a. ni dayana or ni kadai, leave him a. bar shi dayansa; they a. dayansu; a state of being a. kadaichi, to be left a. waiwai.

alongside, daura, dabara, da$b r a$, or followed by $d a$ as a prep., e.g. they stood side by side su tsaya daura da juna. aloof, to keep a. from nesanchi, nisanchi.

aloofness, nisanta.

alphabet, n. abajada, letter of the a. harafi, pl. haruffa.

already, adv. na cl̄̄, dazu, wuri, dauri, tun da wuri; he is gone a. ya rigaya ya tafi. also, adv. kuwa, kau (S.), kawa (S.); usually placed after that which it connects; haryo*, har yau.

alter, v. 1. tr. sake, saki, sauya, musaya.

2. intr. sauya.

altercation, haya-haya, hargowa, hayaniya, tankiya. altered, particip. adj. sauyaye, fem. sauyayya, pl. sauyayyu. although, adv. ko, ko da. 
altogether, adv. bāki daya, cf. $f a u, f o f o *$, also faye and $f i$.

always, adv. koyaushe, kulyaushe, tutur, tutul, kullum, da kullum, yini*, chikin kowanne yay $i^{*}$, judu*, to continue a. tuturta.

am, v., see be.

Amaranthus (native spinach), alayafu, zakin banza.

amazed, to be yin mamaki,

jin mamaki, jin damuwa.

amble, n., of a horse täkama;

a horse which ambles doki mai-takama.

ambuscade, n., see seq.

ambush, n. kwanto, b̆ăgo, fako, maraya; to set an a. yin fako; to lie in a. lăbe (S.), rabe $(\mathrm{K})$, place of or for an a. mafaka.

amen, amin*.

amidst, prep. tsăka, tsăkan, tsăkanin.

amount, large, n. chushe; see quantity.

amulet, talili, see charm.

amuse, tr. v. bada (or sa) murna.

ancestor, n. kāka; ancestors kakanni.

ancestry, see under $b a$. and, conj. $d a, w a^{*}$.

angel, n. malaïka, pl. malaïku. anger, n. fushi pronounced fhushi, haushi, kankanchi, kuna, takaichi, zauta, za.fin rai, bijira (S.), ḳumchin zuchiya.

angle, n. kusuruwa.

angry, to be, v. yin fushi, fusata, yin tsiwa; to be a. with harzuka ga, hasăla ga, chichika,yin chichika, takaita, jin takaichi; he feels a. yana jin haushi.

angry, adj. $d a$ fushi; one who is a. mai-fushi.

anguish, n. $a z a b a, z o g i$.

angular, mai-kusuruwa.

animal, n. b̌ssā, pl. bisashe or bisaje, dabba; domestic animals bisashen gr̆da, wild animals bisashen daji, abin daji or naman daji, pl. namun daji.

animosity, n., see hate.

ankle, n. idon lafa, idon sawu (or sau), pl. ijiyan sawu, or ijiyar sawu, or ijiyas sawu; a. bone dombubu, or dambubu.

announce, tr. v. gaya, fadi, labarta; to a. as a herald does the coming of some one gabato.

annoy, tr. v. dāme, dāma, futina, hayyăta, tayas, wahalda, wahalshe, sa wahala, al'ale; sawarwara, dawainiyasda, tozarta, I am not to be annoyed ba ni damuwa. 
annoyance, n. wahala, sawarvari, takaichi, see anger.

anoint, e.g. with oil or water, tr. v. shäfa, shäfe, yin shäfa. anointing, n. shäfa.

anon, adv. sai an jima, jima kadan.

another, pron. wani, fem. wata, pl. wasu or uadansu; often rendered with kuma, e.g. wani kuma.

answer, n. amsa, amshe, amsawa, jawābi, karḅawa.

answer, v. amsa, yin amsa, to give an a. kăda bāki, karḅa magana; I answered him na mayas masa da magana.

ant, n. different species are: small stinging a. tarmani, tirmani, lkwankwambishi; small black a. chinnaka or chirnaka or tuma da gaya; driver a. kwalkwasa, kwarkwasa; the stink a. gwana, gwano, geno; a red travelling a. makwaiwa; harvesting a. tururuwa; very small black a. kudafi, kudahi (S.); a red biting a kumo; an a. which feeds on honey shazumami; small red a. kiyashi; white ants (i.e. termites) zăgo, fem. găra, gaira, pl. gărani, sansamiya; the white a. in the winged stage shinge, gina; gara is also used of ants generally ; an a. with a large abdomen maidauro a gato; a reddish biting ant ba-fulatana.

ant-bear, see ant-eater.

ant-eater, the great a. or antbear, dapgi, dabgi, dubgi, daugi.

antelope. The following are some of the antelopes found in Hausaland. Senegal or red-fronted gazelle, barewa, pl. bareyi; Dorcas gazelle farin barewa; the roan a. (Hippotragus equinus) gwanki, gwamki (S.); the W. African hartebeeste kanki, pl. kanoki; oryx mariri, marili; Buffon's red cob a. mareya; Addra or red-necked gazelle mai-farin gindi; a Senegal hartebeeste (Damaliscus korrigum) dări; the oribi a. batsiya; the redflanked duiker makurna; the 'crowned duiker' gada; klipspringer gadar dutsi; the water buck (Cobus defassus unctuosus) guambaza, gwanzama, ambbache, dodoka; reed buck kwantarafi, ḳaji; bush buck mazo; a. leucoryx wal$w a j i$; an old solitary a. kishi$m i$; see also matso, karongodce.

ant-hill, n. suri, pl. suwura, 
sura, jǔba, jŭba ; ḳunḳu$w a$.

anticipate, v. tsaitse, e.g. I anticipated him na tsaitse shi; wada*.

anticipation, zăto.

antimony, n. kwalli, tōzali; small skin bottle for holding a.tandun tōzali, gidan kwalli; a stick used for applying a. mashiyi, masayi.

anus, diwa, tsuli, tsuliya, l̦arkashi*, shakira, munta, muriya.

anvil, n. măkēera.

anxiety, n. machiyatc, matamache, mamābi.

any, adj. kowanne, fem. kowache, pl. kowădanne.

anyhow, indef. pronl. adv. ko kaka.

anyone, indef. pron. kowa, kowanene, fem. kowa, kowacheche.

anything, indef. pron. komi, kome; not a., nothing babu komi, ba komi.

anywhere, indef. pronl. adv. koïna.

apart from, adv. banda, bamda, dabam dabam.

apartment, n. (room) laki, pl. dakuna.

apex (of house, etc.), kan daki. apostatize (from Islam), rinda, ridda. apparatus, n. kaya, pl. kayayeki, or kayaryeki.

appear, intr. v. bayăna, baiyăna, guvadu.

appearance,n.kăma, pl. kămā$n u$, or kamannu (S.), halamu*, wato*, watau*.

appease, tr. v. lallasli, lillashi, $s \bar{a} d a$.

appetite, n.kwadai*,kwadayi*. apple, Akee a. alele; balsam a. garafuni; wild custard a. gwandar daji; hairy thorn a. zakami; Dead Sea or Sodom a. tumfafiya.

appoint, tr. v. (to order, used of God) ladarta; (to select. for an office) $z a b a, z a b e$; appointed zababbe, fem. $z a-$ baḅba, pl. zaḅaḅbu.

apportion, to yin fasali.

approach, intr. v. nache, yin kǔsa, doshi, dosa, see near. approval, sale on chinikin shawara.

approve of, v. yard $\vec{a}$; approved of, adj. yardadde, fem. yardadda, pl. yardaddu, tăbatache, fem. tăbatachiya, e.g. magana tăbatachiya approved, i.e. true words; he approves o. hankali ya kwanta da.

apricot, a tree with fruit like a

wild a., n. tsada* ; see plum. apron, n. bante, banche, pl. 
bantuna, kudu; a woman's a. darazau.

Arab, n. ba-ture, pl. turawa; an A. ba-Larabe, pl. Larabawa; the Arabic language Arabiyya, larabchi.

arch, (used in building) kafofin guga (S.), masharuwa*.

arched, an arched roof damren-guga, dauren-guga, masha-ruwa*.

are, v. ne, che, ke; phr. there a. ina, akwai; there a. to me, i.e. I have sun yi ma ni, a yi ma ni; there a. many ina da su dayawa.

argument, jiyeya*, jiyaiyya*. aright, to direct a. daidaita. arise, intr. v. falka, tashi, taso, tsira, tsire, tsiro, or chira, chire, chiro.

arithmetic, hisabi (S.).

- arm, n. 1. (from the wrist to the elbow) damchi, damtse, pl. damasa; the forearm găba ; to hold up at arm's length dăga; a man with a bent a. mai-laushi, mai-lauje, maikwarda.

2. $\operatorname{arm}$ (i.e. weapon), see arms.

armhole, n. hamata, pl. hamatu, hamatta, hamutta.

armlet, n. gen. kwandage, a. made of metal karafa; a. made of natron kărau, kărro, pl. karaurawa, ungurru ; a. made of plaited grass, worn by children darambuwa; a. made of leather and wood dăga.

armour, n. chain or iron a. sulke, saba; a hor'seman's a. kumakumi.

armpit, n. hamata, pl. hamatu, hamatta, or hamutta.

arms, coll. (weapons, etc.) $m a$ kami; battle a. kayan dāga, kayan yaki.

army, dako (S.); the centre of an a. uwar yaki.

around, adv. kewaye, gewaye, prep. kewayen, gewayen.

arouse, tr. v. tada, tashe, tayas, tayas da, falkad da.

arrange, tr. v. gyara; to a. the hair (i.e. to comb or dress the hair) gyarta, shata, shache.

arranged, adj. shiriyayye, fem. shiriyayya, pl. shiriyayyı; gyartache*.

arrangement, (contract) $w a$ habi, sharadi.

arrive at, v. isa, iso, sadu. arrogance, n. foma, homa. arrogant, $n$. one who is a. maifoma, pl. masu-foma, maihoma, pl. masu-homa.

arrow, n. kibiya: pl. kibau, kulere, gora, pl. gororo, or gorina; bow and arrows 
bakan kibiya; a. head fasa, pāsa; a. projecting from quiver zagiya; barbs on an a. kălemu (K.), a quiver for arrows kwarin kibiya; special names of a. poison are tumia or tinia, kwankwani, sainya*, tururubi, uwar magunguna, womagunguna, zabgai, zabo, uwal dafi, gen. dafi; e.g. they (the arrows) are poisoned suna da dafi. Ingredients for making arrow poison are obtained from many different plants. Arrows are made from the reed-like plants, e.g. kyamro, kyamru, kyamare, sheme, gazara, sansari; a. notch gofi.

art, n. gwani.

article, the definite a. $-n$, see the ; the indefinite a., see $a$. as, adv. kăma, yadda, yăda, kauda, ya*, $y i^{*}$; a. before

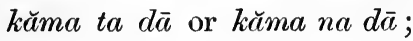
even a. kămar yadda.

ascend, v. shirga, hawa, hau, constr. with b̌sa or b̌sa ga; e.g. he ascended the hill ya hau b̌̌sa tudu.

asceticism, gudun-duniya, tsantsani, tsintseni.

Asclepias gigantea, n. tumfafiya, pl. tumfafi.

ashamed, to be, intr. v. jin kumya, jin kunya. ashes, n. toka, pl. tokuna, habdi (S.) ; hot a. rufushi, rubshi, habdi (S.).

aside, e.g. I turn a. from the path ina ratsewa dăga b̆̌sa hanya; a baya, ga baya*.

ask, v. roḳa, roḳo, yin tambaya; one who asks maitambaya; to a. of or from rokio, roka.

asking, roḳo, continued a., n. kokanto.

ass, n. jăki, fem. jăka, or jăkanyı, pl. jăkai, or jăkuna, ăsuwa; dan bakuru, matuwa; large male a. bingi, a castrated ass aguru; diff. species have the foll. names; a. with red body jimrau; a. with black mouth gofo, red a. aura, reddish brown a. $\check{\imath} d u$ bar, tawny a. oraki and dan oraki; large black a. jaḅa; white a. mugo, shawu (S.); a spec. of wild a. shiyaki; a pad for an ass akumari, leferu, pl. leferai; lafero, laheru. assault, n. (as in war) falmaki, farmaki, firmaki.

assemble, v. gayya, gayyata, tāra, intr. tāru.

assembled, to be taru, particip. tarare.

assembly, n. gayya, al'umma ; royal assembly-room fage, dandali. 
assent, v. kăda kai, gyada kai ; assent is very frequently expr. by kyau as in the phr. da kyau.

assess, to kimanta, aza ma. assimilate, they will not a. ba su haduwa.

assist, tr. v. taya, tamaya, taimaka, taimaki, yin taimako, yin shalli.

assistance, n. tamayi, taimako, taimakawa, shalli, sauki; a. in war gudummawa; he called for a. ya buga găyya. assurance, tabbas. assure, to a. a person of the reality of anything gaskata or gaskanta.

assured, to be a. of (to feel sure) tabbata, tăbatta, tăbbache, cf. seq.

assuredly, adv. da gaskiya, babu shakka, lābudda, babu wawa, faufau; he is a. there ya tabbata nan; he is a. a heathen ko tabbata kafiri ne. asthma, n. fuka, see breath. astonished, to be, v. jin $d a$ muwa, jin mamaki, yin mamaki.

astonishment, n. damuwa, exclamations expressing astonishment haba, gāsara*. astray, to go bakita (S.). astringent medicine, n. magani mai-kama chǐki.

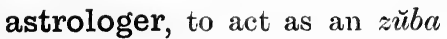
tamrarai.

at, prep. a, e.g. a wuri chan at that place; often prefixed to gare, chǔkin and busa; ga (gare with pronouns), e.g. ga gida at home; dăga, e.g. shi ne dăga nan he is at that spot, i.e. he is there; gun*, e.g. gun chan $=a$ wuri chan.

atmosphere, n. duniya.

attack, 1. farmaki, falmaki, firmaki; a feint or pretended a. zanzoma.

attack, to girsa, girshe, mama, mami.

attain, to a. to same, samu, kai. attempt, v. yin koḳari, tăga. attempt, n. Kookari.

attend, to a. to (to look carefully into) lura; to listen to ji, saurara, daddăra; see attention (2).

attendant, n., an a. on one sick majinyata; the attendants of a king fadawa.

attention, 1. n. (serious thought) hankula, hankali; ruwa, e.g. it is no matter worth my a. ba or babu ruwana.

2. to pay a. to tuna, constr. with da, maida him$m a$; to give a. to what is said ji, sarirara; give a. with your ears (incline your ears to) ka kakartsa kunnuwva. 
attentively, to look at a. tsokachi.

attest, v. shaida, yin shaida, kai shaida.

attested, particip. adj. shaidadde, fem. shaidadda, pl. shaidaddu.

auction, gwanjo*.

auger-beetle, gunda, gumda.

augment, tr. and intr. v. dăda. aunt, n. gwaggwo, a. on the mother's side rafaniya.

authority, n.iko, pl.ikoki, ikontaka, alfarma*, a person in a. mahakumchi, mahukumchi.

avarice, n. zargi, zalimi, zalumi, rowa, rowwwa, măda, madda.

avaricious, adj. mairowa, $d a$ măda.

avaricious, to be yin zalumchi. avenge, tr. v. rāma, sāka.

avenger, mai-rama.

average (adj.), tsăka-tsăka, madaidaichi, pl. madaidaita. avoid, v. kalmăsa, kalmashe, baudi, waske, zāge, cf. a thing to be avoided abokin kiyeye. avoidance, i.e. of a missile, etc. gochiya, guchiya, waskiya. await, to wait for one jira, jirache, jinkirta.

awake, intr. v. farka, falka; awaking falkawa; a start or exclamation on awaking firgigi*. awaken, to tāsad da, falkad da. away, to get a. (escape) fichi, fiche.

away, adv. phr. a. with him yi da shi.

awkward, shallali.

axe, n. gatari; a. for cutting stones dundurusu; a. for cutting grass gizago, gisago; a. with broad blade barandami, tsitaka; battle a. gāfiya, gita (K.), walwada, warwada; the point of an a. head which projects through the handle suga (S.).

axe-handle, n. bota (K.), kota.

babbling, n. rawatsa.

baboon, n. bika, pl. bikoka, gogo, yimki (K.).

baby, n. jarīri, jarīli, yarīli, jinjiri.

bachelor, n. gwabro, gwauro, gauro, gwamro, balaguro* ; namiji da shara, lit. one who has to sweep his own dwelling.

back, n. baya, janfi*, hence bada janfi to put to flight; to turn the b. bada baya; phr. on the $b$. rigingine, on the $b$. of reran; to be hollow backed gantsarwa.

back, e.g. to come b. komo; to go b. koma ; to move b., intr. v. gusa, gulgusa, gurgusa. 
backbite, tr. v. chim baya. backbiting, tsēgumi, tsogumi. backbone, n. tsatso, tsotso, kashin tsatso.

backward, adv. (on the back) rigingine.

backwards, adv. baibai, e.g. they walked b. su ka tafi baibai.

bad, adj. mugu, fem. mugunya, pl. miyāgu; mamuna, mummuna*; used of corn tsadari ; b. man dan duniya; the expr. farikobaki often = good or bad. bad, to go b. rüba, riba, as meat or fruit ; to render b., to spoil rubachi.

badger, n. takas.

badness, n. mugunta.

baft, grey b. akoko; see cloth. bag, n., a small b. aljifi, aljifu, pl. aljifaye or aljifai; b. made of grass with narrow opening ashasha; b. for cowries birgami, burgami, burgame (S.); woman's b. made of grass burma, burima; small b. for carrying salt chukurfa; b. of feminine luggage fago* or pago*; leathern $b$. for camels, etc. gurara; large skin b. for cowries jikka, pl. jikkuna, or jikkoki, kyankyandi; b. holding 20,000 cowries kwaroro; very small b. rarita, lalita*;

R. H. D. long, narrow salt-b. lange; a leathern pouch used by barbers etc. zabira; skin b. or bottle salka, pl. salkuna; small leathern or grass b. sarita; large $b$. for holding rice sŭbolo, saulo; a small leathern b. kumaro, komaro, tānwara $(\mathrm{K}$.$) ; a large leathern$ b. māla, pl. malalaki; a b. made from tukuruwa leaves tādăli; leathern narrowmouthed b. sulkumi (S.), surkumi (K.); large skin b. taiki, pl. taika, tayukka, or taikuna, buhu (Z.); small goat-skin water-b. tandawa$r a$; small provision-b. tanwara; leathern bag closed by two strings pulled in opposite directions alagwami; a money-b. made of skin or cloth tsaleta, salita.

baggage, n. kaya, pl. kayayeki; see goods.

bail, see surety.

bake, tr. v. tuya, toya, găsa, the latter also spec. used of baking bread, e.g. ya găsa gurasa; baked (i.e. fully baked = the Engl. colloquial 'done') ninanne (S.), nunanne (K.), pl. nenannu or nunannu; (cooked) toyayye, tuyayye.

bakemeat, tuya, pl. toye-toye. 
balance, n. a pair of scales maauna, maauni, mazani, mizani; abin awo.

balance, v., to b. a load on the head digirgire.

Balanites aegyptiaca,

n. aduwa.

bald, adj. mai-kora, mai-saiḳo, mai-sanko, mai-kwambe.

baldness, n. kora, saiḳo (S.), sanko (K.), kundumi, kundimi, kundumin kai; cf. prec. bale, of goods fugŭma, huguma; see load.

ball, n. makodi*, kwwălo, mulmule; a small b. dan kodi; b. or brick made of mud tubali; b. of the eye kwayan ido; (bullet) harsa, harsashi; to roll into a b. dunkula, kudundune.

ballad, n. waka.

bamboo, a sort of, n. gora, kwangi*.

banana, $n$. the b. tree, or fruit ayaba.

band, n. 1. (company or gathering) taro or taru, pl. tarori.

2. (strip for binding) cf. seq., a leathern band worn round the neck goli (S.).

bandage of any kind, n. rawani, pl. rawunna.

bandit, n. mai-fashe, pl. masufashe.

bandy-legged, adj. gwami, mai-gwami, chassa (K.), tarkoshi (S.).

bang, an exclamation pom, pam. bangle, for wrist kărau, kăr kărau, munduwa, manduwa, pl. mundaye, mandaye.

bank, n. (=edge or margin) $b \bar{a} k i, g \bar{a} b a, g a c h i ; b$. of a river gefe, bākin ruwa, gachi, gāba, refe.

banner, n., see flag.

baobab (Adansonia digitata),

n. kuka, pl. kukoki; fruit of the b. tree llwame (S.).

bar, n. (a rod or stick of wood, iron, etc.) sanda, pl. sanduna; a b. of iron sanda ta karife; b. used to close a doorway gagara-bado.

barbarians, n. 1. (of men in a rude, uncivilised state)baibai, baibaya, baibayi, or baubawa (S.).

2. (cruel) $d a$ mūni. barbarity, n. (cruelty) mūni. barbarous, see barbarians. barber, n. wanzami, pl. wanzamu, wanzamai; a hairdresser is mai-kitso. barbs, on an arrow ḳălemu (K.), kun-nuwan kibiya.

bare, see naked. bareness, n. wofi. bargain, n. (bargaining) chini$k i$, tăyi; a discussion before making a b. alwāshi; the 
conclusion of a b. yardajeniya; to haggle over a b. yin chiniki; to make an offer in bargaining, see seq.; a b. (cheap) da araha, da arha; into the b. (= besides, as well) banda wannan.

bargain, v. tăya, tayi, yin tayi, yin chiniki.

bark, n. (of a tree) fäta, pāta, bawon itache.

bark, tr. v. (to strip off b.) kware, kwari.

bark, intr. v. (of $\operatorname{dog} \mathrm{s}$, etc.) yin hafshi, yin hapshi, yin habshi, yin haushi, yage.

barking, n. (of dogs, etc.) hafshi, habshi, haushi.

barley, n. sha'air.

barn, n. rumbu, rafoniya, rufogo.

barrel of a gun, n. baki; a double-barrelled gun bindiga mai-baki biyu.

barren, adj. (used of the female sex) karara, bakarariya, matauriya; (used of a sheep or goat which has not had young) kazgainya; a b., or fallow, tield sabra, sabara, saura, tsandauri.

barrenness, n. (of woman, etc.) tauriya, rashin haifuwa. barricade, n. kăgara, kĕgaruwa, pl. kăgaru, gagarabado. barrier, n. kăfi.

barter, n. chiniki, sărafi, tăyi, furfure, sărafa, rangama.

barter, to sărafa, yin chiniki,

tăya, yin tăyi; see bargain. base, adj. (of low worth) banza. base, n. 1. (lowest part or bottom of anything) kalkashi, karkashi.

2. (=support or foundation of anything) gutsu, or guzu*, which is used physically and also figuratively; gindi, tushe.

bashful, adj., see seq.

bashfulness, n. kumya or kunya; to feel bashful jin kumya, e.g. when asking you for this, I felt bashful da $n a$ roke ka wannan na ji kumya. basil, wild b. daidoya (K.), dodoya (S.).

basin, n. kwachiya, gwangwan, a metal b. dāro.

basket, n., a large b. for salt etc. adila or adilak kaya; large b. or pannier made of grass gufa, gufata, kantalma; a b. made of palm fibre lefe; a small grass b. used in making bread marari; a large grass b. sanfo or samfo, pl. sanfuna; kwando; a b. used as a strainer kindi, pl. kindodi, marari; a small b. used by women kwatashi, 
taskira, tazkira; a b. used in fishing suru; a b. full of corn totsiya. See under bag. bastard, adj. shēge, fem. shēgiya, pl. shègu, dan farka, dan nema.

bat, n. tattapara, birbiri, rugi, tsabilbila, yabirbira, ḳanen jemāge; a large-sized fruit b. jemāge.

bathe, to kurma, kuruma. bathing, kurme.

battle, n. fama, fada, gā ba, yaki, the latter is also the proper word for war, q.v.; b.field clāga.

battle, to draw up in line of b. ja dāga.

battlefield, n. kangan fada. bawl, n. yin kuka, yin ufu. bdellium, African b. dashi. be, v. 1. ne with masc. subject, che with fem. subj., ke with either; they may follow the subj. but are often found at the end of their clause; e.g. he is truthful shi mutum mai-gaskiya ne; she is very beautiful ita kyakkyawa che; both of them are old su biyu tsofi su ke; the above chiefly express the simple copula, but see below (3).

2. kashi, kashe, kasanche, used where emphasis is laid on the fact or continuance of existence; they are frequently used in written, but seldom in colloquial Hausa.

3. akwai (sometimes pronounced akwoi), implying real existence, there is, there are, there was, there were, e.g. are there elephants in this town? akwai giwaye a garinga? ans. there are $a k$ $w a i$ : $k e$ is often found with nan in this sense, e.g. there was a certain jerboa wani kurege ke nan=akwai wani kurege.

4. na (masc.), ta (fem.), are sometimes used in place of the substantive verb, e.g. the men are doing so mutane na yin hăka, the horses are running away dawaki na gudu; for this use of na see H. Dict. I. p. 273.

bead, n., beads chasbi, chasba$h a$; a large white b. in a set of black alāma, pl. alamomi; round blue b. galan kumburi; a large white seed used as a b. gimba, pl. gimbai; a large (Phoenician) b. dilari; a small red b. rigigi; a red coral b. bajumba; a blue cylindrical $\mathrm{b}$. worn by women samfalwa; red beads dimbujin zufa, dumbaji, jinin kafiri; beads made from black seeds 
kantururuwa; necklace of beadskutofi; beads worn round the neck by women tagode; string of beads worn round loins kwatana ; pearls or red beads murjan, murjani; large red b. murjanin tudu, rigigi (S.), rikiki; prayer beads tasbi, pl. tasbai; a woman's girdle of beads kwatana, tsăkuwa. bead-tree, kurnan nasara. beak, n. ķoto, bakin tsuntsuwa, $g e b e^{*}$.

beam, n., b. above door almanāni; a cross b. kuba; b. or post stuck in the ground to support a roof dirka, jīgo, pl. jiguna; b. for pumping water jēgo, kutāra.

beam, of light giraza, girazal rana.

bean, n. wake, pl. wakoki or wakaikai; red edible b. tsarariya, tsurariya (K.), kwama (S.) ; small b. komo; mahogany b. kawo; sword b. barankachi; yam b. giri giri; beans ground up and cooked in water tubāni, tabāni, tubuni; a species of large b. zako. bear, 1. (to carry) kai, shide, constr. with $d a$.

2. (to produce their kind, of animals, trees, plants, etc.) haifa, haife; to b. in the ear as corn goyo.
3. (to endure) jimri, (to b. with one) jimrache. beard, n. geme (S.); gemu (K.), pl. gema, or gyamma (S.), gyammai (K.); b. of goat rairo, rero.

bearded, a b. man mai-geme, pl. masu-geme.

beardless, adj. shagiri, pl. shagirai.

beast, n. bǐsa, pl. bisashe or b̌saje, dăbba, dăbbo, pl. dabbuna or dabbobi; wild b. naman daji, firdi*; wild beasts b̌sashen daji, namun daji.

beat, tr. v. 1. buga, doke, duka, dirka, the last is sometimes written tsirka, bada kāshi.

2. to b. down, as earth etc. taka, taki, tsaga, tsatstsaga, dăbe.

3. to b. or tread grain dăka, intensive form $d \breve{a d}$ daka, swaba (S.), surfe, taki, tingama.

4. to b. a drum yin wargi; see drum.

5. to b. in war, intr. yin nasara, trans. chi.

6 . to b. in a game chi, e.g. na chi ka I have beaten you.

beaten, part. adj. in sense of prec. 3. takakke, fem. takakka, pl. takakku. 
beating, n. 1. tsirka, dirka; see beat.

2. $k \bar{a} s h i$, (a defeat in war) artai.

3 . b. of wings $t \bar{a} f(\mathrm{~K}$.$) ,$ taḅi (S.).

beautiful, adj. da kyau, kyau, mai-kyau, kyaukyawa, kekyawa, kyakkyawa.

beauty, n. 1. of persons and things kyawo or kyau.

2. of dress ornaments etc. $\breve{a d o, ~ a r m a s h i . ~}$

because, conj. don, chewa*, domin chewa*, gama, zama (S.); chewa and domin chewa are used in written, but not in colloquial Hausa.

because of, prep. domin, don, săbada or sabad da, săboda*, săbo (K.), găma, sabili da, zama (S.); b. of me domina, b. of him dominsa.

beckon, v., to b. with the head (in token of assent) gyada $k a i$; to b. or shake the head (in token of denial) kăda kai; to $b$. with the hand yafuche, yafuto.

beckoning, (with the hand) yafuchi.

become, intr. v. (to come to be) zăma, zam (S.), samma*, kawa*, sawoya.

become, intr. v. (to befit, to be proper) kămata, kămache. becoming, adj. (lawful, ceremonially right) halal, halas or halata, daidai; it is b. ya yi daidai.

bed, n. gădo, pl. gădaje or gădashi, karaga*; to go to b., v. kwanta; a b. of mud dakali, tugufa; space under a b. in which a fire can be put tsāriya, tsāri.

bed-clothes, coll. n. mayāfi.

bee, n. ḳudan zŭma or ḳudan zummuwa, pl. kudashen zŭma; the mosquito $b$. or stingless $b$. găla, galla, rakuwa; young of b. gudajen zummuwa; small bees sofofuwa; ground bees ganya.

bee-eater, (bird) tsuntsun hayaki, tsiriyar kogi.

beef, n. naman sa, naman shanu. beehive, n. ainya, amya (K.), hamya, butumi, pl. butuma, burtumi (S.), gidan zummuwa.

beeswax, n. dankon zummuwa, kakin zummuwa.

beetle, n., spec. large, black, long-legged b. gurgunguma, kurgunguma, burgunguma, sări; the 'plush b.' or 'velvet mite' karamuski or mulufi*; burying b. or dung b. buzuzu; click b. makeri ; blister b. hangara; auger b. or wood borer kichichiya, gunda ; longicorn 
b. or leaf-cutting b. mageduwa; tiger b. (larva) furau; water b. kumbudiya (S.), kumbudewa (K.).

befall, intr.v. samu, same, sama, sami; it befell him ya same shi. befit, intr. v. kămata, kămache. before, adv. of time da fari, tu-

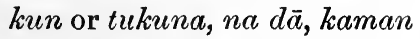

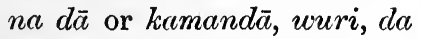
wurior dauri, dazu; in former time lokachin dā; see ever. before, conjunctive adv. găba, kajin, b. that kani*, kamin, kana, kan da, kan*, e.g. finish this b. (that) you do that kare wannan kana ka yi wanchan; tun and tun da are employed with negative clauses, e.g. b. (that) he died he composed a book tun ba ya mutu ba ya yi wani litafi; to go b. gabāta, gabāche, rigaya, he was at the farm $b$. her ya riga ta gona. befriend, tr. v., see assist. beg, v. 1. (to entreat, supplicate) roka, yin roko, biko.

2. (to ask a thing of, as alms) băra, yin băra, roḳo; I b. pardon gafara ma ni (or mini); to b. for help zukatta*. beget, tr. v. (of the male) haife, yin la.

beggar, n. mai-băra, mai-roḳ, marok*, fem. marokiya, al- majiri, fem. almajira, pl. almajirai, madăha, mauro, gardi*; spec. an idle b. mai-kasala, a b. on the road masarchi, a b. who sings a great man's praises ma'aba, one who lives by begging food mai-kwaraka.

beggar, to wander alone as a b., intr. v. kasala*.

begging, n. marokachi, roko. begin, v. fära, yin fära, dọa, soma (K.); to b. work kāma aiki, farma*; it cannot be begun ba shi somuwa.

beginner, a (i.e. learner) bami. beginning, participial n. farawa, farko, ta-farko, somi, masomi, mafäri; from the b. of the world dăga mafarin duniya.

beguile, tr. vo rude; see deceive.

behave, intr. v. (to turn out, prove) zama, e.g. na zama da hankali I shall b. wisely; maida*.

behaviour, n. (character, conduct) hali.

behead, tr. v. yanke, debe kai. behind, adv. baya, a baya, dagga baya; that which is $\mathrm{b}$. abin baya.

behind, prep. baya, baya ya, with suff. prons. gare, e.g. b. them baya gare su. 
behold, v. duba, dubo, gani, tsokachi, yin kallo, exclam. phr. b. duba! b. him or it ga shi! b. her or it ga ta! behove, to kămache, kămata. belabour, tr. v. buga; see beat. belated, to be, i.e. to be late in arriving yin yauchin zakuwa, makara.

belch, intr. v. gyatsa, gyasa, gyashi (S.).

belief, n. 1. (creed) addini, imanchi.

2. (credence) ban gaskiya.

believe, v., to b. a fact gaskata, gaskanta, to b. a person bada gaskiya, yin gaskiya constr. with prep. ga; to b. in, esp. to b. in God, kasada ; I do not b. it ban karba ba.

believed in, particip. adj. yardadde, fem. yardadda, $\mathrm{pl}$. yardaddu.

believer, n. mumini, fem. mumina, pl. muminnai.

bell, n., small b. attached to horse gwarje, gwalje, gurje ; small bells on horses' heads chikasaura, chikasabra, chakasabra, chikasaura; bells attached to goats etc. kărraurauwa or kararawa.

bellow, intr. v. ruri, yin bu. bellowing, n. $b u$.

bellows, n. mafuri, mafurin wuta, zigazigai, zugazugi; a man who blows b. mazigi; the stick of the b. maziga.

belly, n. kundu; lower part of b. māra, cȟ̌ki.

belong, intr. v. 1. (to be the property of) $n a$, fem. $t a$ with the forms of the v. to be, e.g. this book belongs to Hassan litafin nan na Hasan ne, the horses $\mathrm{b}$. to the king dawaki na sariki ne, that stick belongs to this man sanda chan ta mutumen nan che, it belongs to me nawa ne or ni ke da shi.

2. (to be native of) e.g. he belongs to Kano shi dan Kano ne.

belongings, $\mathrm{n}$. (property) $d u$ kiya, and in a still more general sense abubuica.

beloved, n. masoyi, fem. masoya, pl. masoyu, lele or nalele*; a thing b. abin ḳamna. below, 1. adv. a kasa, a ḳas, baya*.

2. prep. kalkashin (S.), karkashin (K.).

belt, n. abin damre, madamre, damăra, pl. damăru; b. for sword hamila; see girdle.

bench, n. kujera, kushera, pl. kujeru.

bend, tr. v. kalmăsa, kalmisa (S.), kalmashe, karkăta, gusda, kantara, sunkwiyad da, tankiosa, tanḳwasa, tankwware, 
jirga, lauya; spec. to $b$. the head kăda kai, kankanda kai, sadakai, karkătä or kakartsa* with or without kunne (ear) to b. down (the ear) in order to attend to what is said; intr. dukad da, jirge, kantare, lankwashe, lankwwasa, sunkwiya, duka; see bent. bending, n. dukawa, laudi. beneath, adv. and prep., see below.

beneficial, adj., see seq. benefit, n. anfäni; of b. (beneficial) da anfāni, mai-anfāni. benefit, (confer a b. upon) anfäna.

benevolence, $n$. (an act of b.) kyauta, abin kyauta, alheri. benign, see kind. beniseed, ridi, lidi.

bent, adj. gangare or gangara, pl. gangaru; b. or tottering, as of a wall, karkache, fem. karkata, pl. karkatu; a b. tree kwandariya, ḳondariya* ; a man with a b. arm mailaushi, maikwarda, with a b. leg gwami, old man with b. back takoko ; it cannot be b. ba shi tankuasawa. bent, to be yin gangare, karkache.

Benué, the river, pr. n. Tsāda, or ruwan Tsāda.

benumbed, to be, intr. v. kage* or kaga*; my foot is b. dela ya kama kafata.

bequeath, to wasiche*. bereavement, n. kewa, kiwa. bereft (devoid of) in phrases like b. of sense maras, rashi, e.g. maras-hankali, b. of shame maras-kumya, b. of strength rashin larifi; see under răsa.

beseech, v., see ask. beseem, v., see befit. beside, prep. (at the side of) wajen, a wajen; in a looser sense, kusa ga, tare da.

besides, prep. bamda, ban $d a$, baya, bayan, baya ga.

besprinkle, buta, yāfa, yafa ruxa.

best, adj. this can only be expr. by the phr. ya fi duka, mafi duka, or ya fi kowa; this is the b. of these wannan mafifichi dăga wadannan ; this is the heaviest wannan ya fi duka nauyi; he is doing his b. yana $d a$ jimri; cf. Hausa Gr. p. 75. betray, tr. v. (to deliver up treacherously) bashe; to $b$. confidence chir amana, or chinye amana; to $b$. one another bada juna.

betroth, tr. v. rike, rika, riki. betrothal, riko.

better, adj. 1. gen. dama, 
gwama, gwamma, e.g. it were b. ya yi dama; (superior) mafifichi foll. by daga, e.g. this is better than that wannan mafifichi dăga wanchan, or wannan ya dadi wanchan; $f i$, e.g. it is b. so ya fi; gara, gaira, guma, gwamma, e.g. it is b. gara, it is b. so gara $h \breve{k} k a$, or gwamma hăka, it is b. for me to stop ni gara in tsaya, rather than I should do this it would be b. to die da na yi wannan gara in mutu.

2. a b. state of health is expr. by means of dama, afuwa, ranguame, e.g. to feel b. jire dama, jin rangwame, to get b. samu dama, also by wartsaka, b. to-day than yesterday gwamma yau da jiya, see Hausa Gr. p. 75 .

between, 1. adv. tsăka.

2. prep. tsăkan, tsăkanin.

3. n. (a space), b. tsăkani. bewail, v. 1. intr. yin kuka.

2. tr. expr. by 1. with preps. given under on account of.

bewailing, 1. particip. n. (the act of b.) kukawa.

2. concr. (wail) kuka. beware of, v: yin hankali, tına, constr. with prep. $d \alpha$, e.g. b. of that $\log$ lest you fall over it ka tuna da ichen nan kăda ka fadi b̌sa.

bewilder, tr. v. dāme.

bewildered, to be, intr: dāmu, jin damuwa, rude.

bewilderment, n. damuwa. beyond, 1. adv. of place baya, $g a b a$; (further on, at a distance) nesa, da, or dăga or na nesa, e.g. that which lies b. abin baya.

2. prep. baya, bayan, keetaren.

3. fig. (surpassing) faskare, $f i$, e.g. it is b. me ya faskare $n i$ or $y a f i n i, \mathrm{~b}$. the power of man ya fi mutum or ya fi karfin mutum.

beyond, to go, v., e.g. he went b. sea ya letare gulbi.

biceps, kwanduwan hannu.

bid, n., a b. tayi.

bid, v. 1. (to command) hakumche, hakumta.

2. (to offer a price for) taya, tayi, yin tayi.

bier, mākarai.

bifurcate (of a path), birkichi, birkita.

big, adj. 1. (of size) babba, pl. manya, ruku-ruku* ; also fig. (important), e.g. a b. man babban mutum or mutum $b a b b a, a b$. thing ridimin $a b u$; to grow b. gawurta, gawusta, 
the boy has grown b. yaro ya gawurta ; full-grown gawurtache, pl. gawurtattu.

2. (pregnant) da chiki, karambiki.

3. (pompous, arrogant) $d a$ girman kai, mai-homa, pl. masu-homa.

bile, n. machiwa (S.).

bill, n. 1. (account) lisafi or lesafi.

2. (beak, q.v.) koto.

bind, tr. v. 1. damre, daure, lamra, darme, tanka, tanke, lamyache (K.), sarkafe ; spec. to b. fast tsūke; to b. grass with cords so as to form roof yamche or yamchi.

binding, particip. n. sarkaferva; boards or stiff covers for $b$. books bango, trdarishi; b. of corn bambu.

bird, n. tsuntsu, zunzu*, fem. tsuntsuwa, zunzuwa*, pl. tsuntsaye, zunzaye*. The following are some of the commonest birds in Hausaland : bishop-bird, dala, mulufi; bustard, the lesser b. kadabkara, kadafkara, katakara, sokara* ; the greater b. tuje; crow shimkake, a whitebacked c. hankāka, pl. hankaki or hankaku; crane, crested c. gauraka, goraka, garmaka, gamraka, kurki*; cuckoo (lark-heel c. or crow pheasant) ragon maza; dove kurchiya, garda, bardo, hazbiya, wala; eagle gaggafa; egret (great white e. or heron) zarḅi, zalbi ; little e. balbela, badbila, bilbila; finch chigoro, sisita, shaida, baiwar Allah, zalaidu; honey-guide gunda, maganiya; hoopoe chigi da tuku, katu tu; hornbill burtu, bultu, chilikowa, ka-ki-ganin-Allah; ibis (African wood i.) tsagagi, jinjimi; Hadadah ibis rara; partridge (or francolin) fakara (K.), makeruwa (S.) ; pigeon tantabara,tandabara; ploverkyarekyare, zakaran yaki, zakaran assuba, dan raguwa; blackheaded p. or crocodile bird ladin kogi; roller or blue jay chanwaka, tsanwaka; starling dokin buntu; glossy $\mathbf{s}$. or grakle tsakwaikwaiwa; stilt taka bado; stork shamo, shamuwa, kasheri, mai-jika, borintumke, babba da jikka, tsagagi, juhurma; sun-bird sha kauchi; swallow (a species of s.) tsaitsewa, mashirari; weaver b. jira, kābare. The following have not yet been identified: a small white diving b. benema; a large carnivorous b. $d u k i$; a yellow- 
breasted b. gado; a species of sparrow gora; a small b. with red plumage which feeds on guinea-corn marai; a small singing b. wali, waliya; a long-beaked water b. sulbi; see also banupiya, buwa, kajarini, kilabtu.

bird lime, n. danḳon tsuntsuwa.

bird's-eye, idon zakara.

birth, n. 1. (coming into life) haifuwa; since your b. tun haifuwark $a=$ since you were born.

2. (the act of bringing forth) haifuwa, jego.

3. an untimely b. $b a$ kwaini, barin chiki.

birth, to give b. to, tr. v. haifa, haife, yin jego.

birth, a woman about to give b. to a child karambiki.

birthday, n. rana ta haifuwa, ranan haifuwa.

birthplace, n. mahaifa*, phr. wurin da aka haifa.

biscuits, akara*.

bishop-bird, or cardinalbird, dala, mulufi.

bit, n. 1. (of a horse) lizami, linzami,lizzami(S.); the strap tied to a b., n. kamazuru.

2. (small piece, fragment) gutsura, pl. gutsatsari.

bitch, n. kăriya. bite, n. chizo; b., e.g. of a scorpion däni; b. of a snake sāri.

bite, tr. v. chizo, yin chizo, chije (followed by pron. obj.); of snakes etc. (to sting) sära, tăba, halbi, tăma (S.); to b. off gätsa, zabta; to b. at gurgura; to seize with the teeth tasamma, tasoma (S.). bitter, adj. da dwachi, da dachi, yamama, yanyanna, da yami, madachi; to make b. or to be b. tsamama.

bitterness, n. dwachi, dachi. bivouac, on a field of battle kwanandāga.

black, adj. băki, fem. băkaa, pl. babbaku; very b.băki kirin (or kerin), baki wur; a b. horse akawali, kiyara, chichiro.

blacken, intr. v. (to become or turn b.) zama băki, sauya băki, babake* ; tr. (to make black) babaki*.

blackish, băki-băḳi.

blackness, bakintaka.

blacksmith, n. mai-kira, makeri, fem. makeriya, pl. makera; the fem. $=\mathrm{a}$ blacksmith's wife.

bladder, n. mafitsara, jika*. blade, n. 1. (of corn etc.) kăra, pl. karare, tofo, fofo, zangare, zangarniya.

2. (of knife) karifen wuka. 
3. (broken b. of sword) kuduru*.

blame, n. 1. (finding fault, reproof) foro, tsawa, harasa, rarauka (K.), zarge.

2. (fault, guilt) laifi.

blame, tr. v. 1. (to reprove, check) yin tsawa.

2. (to impute guilt) bada laifi.

blameless, adj. maras-laifi, babu laifi.

blanket, n. bargo, burgo, luru, kuntu*, kuntukuru*.

blaspheme, v. yin alfasha, yin swabon Allah.

blasphemy, n. alfasha magana, ma'asi*.

bleaching, chalk used for, $n$. alli.

bleat, intr. v. kāra and gen. yin kuka, yin bu.

bleating, n. $b u, k \underline{a} r a$.

bleed,v. intr. tsaga or phr. zubda jini ; tr. fita jini or fidda jini, constr. with prep. ma.

bleeding, particip. adj., see bloody.

bleeding sickness, n. tsagiya; b. from nose hăbo.

blemish, n. 1. material or physical b. aibi, aibu, pl. aibobi, aibu, lăhani; e.g. a b. in the eye lăhaniga ido; b., e.g. a spot of different colour in cloth etc. sōfăne, sōfăni, surfani.
2. moral b. aibu.

bless, v. barka, albarka used with yi or wa, e.g. he blessed ya wa albarka; albarkata, kyautaye.

blessing, n. albarka, salati*.

blight, e.g. on corn domana, mando.

blighted, adj. applied to corn kupturu, kŭturu (S.), see birtuntuna.

blind, adj. makafo, pl. makafi; a b. person makājo, fem. makafunca (S.), makauniya (K.), pl. makāifi makabta (S.), makanta (K.).

blind, tr. v., to make b. $m a$ kamta; intr. to become $\mathrm{b}$. makafche, makamche, makanche.

blindness, n. makamta, makanta, makopchi, makabche, makabchi.

blink, intr. v. rumtse, rumtsi, runtsa (S.).

blinkers, leathern b. for a horse furtali.

blinking, n. kifil kifil.

bliss, n. ni'ima*.

blister, n. 1. i.e. something to cause blistering farsa.

2 . of the skin sali, swali, swale, bororo.

blister, v. 1. tr. farcha.

2. intr. (to be blistered) yin sali. 
block, e.g. of salt or potash baura (S.); b. of wood firde. blood, n.jini; b. lettingjiniya, jirfa, jarfa, majinachiya.

blood-feud, tarna.

bloody, adj. (bleeding or bloodstained) da jini; his face was all b. fuskassa duka sai jini.

blossom, n. fure, pl. furori or furaye.

blot, n., e.g. of ink dole, dangwale; to make a b. dardasa. blot out, v. yin maimai, shashafe.

blow, n. gen. buga, kādi, rotse, roche; a b. esp. in boxing dambe, tika, a b. in fighting $f a \breve{d} d a$, pl. fădodi, a b. with hand mari, pl. marumari, or maremare, bugu, bugo, a hard b. causing wound or swelling rotsi, rochi (S.), pl. ratsa, a b. in punishment fig. sanda, pl. sanduna.-To strike or give blow or blows, v. gen. buga, intens. bubbuga or bugabuga; mari or mare with intens. participial n. marmarawa; rochi, rotsa, wulakanta, tsam$k i$, daka with intens. forms daddaka and dandaka; a b. with clenched fist dundu, naushi, I gave him a b. that left its mark na yi $m a s a$ rotsi, the sound of a b. kumus (S.). blow, v. 1. tr. būsa, dăbar, yin dăbar, e.g. the trumpeter blew the trumpet mai-būsa ya busa kafo; to b. away bushe.

2. intr. bussa, e.g. the wind used to b. all night iska ta kan büsa dare duka; spec. to b. the fire under a cooking pot girke, girki; to b. water out of the mouth tuddas; to b. a fire zuga, fura, e.g. b. up the fire with the bellows ka fura wuta da mafuri; to b. up, e.g. an empty bag yin bokoko, to b. up a bag füra salka; to b. about jake. blowing, n. bussa, e.g. the b. of the trumpet, wind, etc. busan kafo, büsan iska; b. of water out of the mouth tudaswa.

blown upon, i.e. dried, adj. büsashe.

blue, n. shuni or juni *, dăfuwa. blue, adj. shudi, fem. shudiya, pl. shudodi, da shuni or $d a$ juni*, dăfăf $f$; spec. b. cloth shiyodi, turkudi, saki, swaki; light b. shudi-shudi; a b. stone kaule; a dark b. thread nati.

blue, to be, intr. vo saki*, soki* or swaki*; to stain the face b. dambara; to dye b. shuda, shiyuda.

bluff, alwāshi.

blunder, see mistake. 
blunt, adj. da laushewa; in the sense of devoid of edge babu kaif.

blunt, to be, v. dallashe, dallishi, dakushe, yin dakŭsa.

bluntness, n. (of a knife) taderishi, laushiwa, dakŭsa.

boar, the wild, n. alhanzir, hanzir, gyado, fem. gyadainya, pl. gyadodi or gyaduna.

board, n. (plank) faskare; to make into boards yin faskare, coll. boards karauki, boards for binding books tadarishi*. boast, v. gawurta, gawusta, yir kurari, yin răha, ruba. boaster, n. mai-foma, pl. masufoma, mai-homa, mai-tama, pl. masu-tama; b. in war gugirma.

boasting, n. foma, homa, tama, alfahari, alwāshi, fari, fariya, kurari.

boat (i.e. canoe), n. jirigi or jirgi, pl. jirage.

boatman, n. mai-jirigi, pl. masu-jirigi.

bobbin, mătāri.

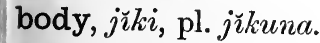

body-guard, one of the king's,

n. zarumi, zaromi, zarmi or jarimi, pl. zarumai.

boil, n. kurji, kureji, pl. kurareji, ḳuraje; kirchi, gurje, girje, bambaroki, maruru.

boil, v. tr. or intr. tafasa, yin tafasa, tafasu, tafashe, taso; it is boiling ana tafasa. boiled, past part., tafasashshe, fem. tafasashiya, pl. tafasassu. boiling, n. taswa; the rise and fall of b. water habuma, hambuma.

bold, adj., see brave.

bolt, v., to b. food rushe (K.). bolt, see lock.

bone, n. lakshi, pl. kiasussuwa or kassa ; back-b. Kashin tsotso; bones in a fish kayar kifi; shin-b. kŏbri, ḳwabri, ḳwauri (K.), ǩubri, pl. kwwabruka; hip-b. kwankwasso ; marrowb. tantakwashi, tantakoshi. bone-setter, mai-dori.

book, n. litāifi, letāafi, pl. litātafi, or litattaffai, or litattaffaye ; takarda*, pl. takar$d u *$, kundi, pl. kundaye, dan kundi, kitāba*; leathern case for a b., n. gafaka, gafakka, or gufaka (S.); large thick b., n. sufuri, sufili; page of a b., n. warka , waraka; stiff covers for a $b$., n. tadarish ${ }^{*}$, bango, pl. bangaye or banguna.

book-marker, n. alama or halama, pl. alamomi, amara. boot, n. kubuta*; spec. long leathern b. safe, high riding b. karufa, kurufa, kurfa, long riding $b$. with spurs 
kufita, kufuta, pl. kufitai, kufutai.

booth, n. bukka, pl. bukkoki; sayi, pl. sayoyi.

booty, n. abin kwache.

border, n. 1. of a country iyaka.

2. silk b. on woman's dress hashiya.

3. b. of cloth lafe, lafi.

bore, tr. v. fuda, fude, buda, huda, yin rarake.

boring, n. fudi, rarake.

born, pass. part. haifaffe, fem. haifaffa, pl. haifaffu.

borrow, tr. v. yin ăro, ramta, yin ramche, e.g. I did not b. much money ban yi ramchen kurdi dayawa $b a$; to $\mathrm{b}$. money chin bashi.

borrower, n. mai-chin bashi, mai-daukan bashi.

bosom, n. gaba, pl. gabobi, kirji, pl. kirjai, kiraza.

both, 1. adj. biyu, e.g. b. of them duka biyu or su biyu; this may also be expr. by dăga wannan sai wannan.

2. conj. $d a$, e.g. b.... and da...da.

bottle, n. tasa or dasa*, pl. tasoshi, kwalaba, kwaliba; tulu, pl. tuluna, dalulu; small earthenware b. butc, water b. calabash kurtu, burmi, gyandama, skin water $b$. salka or salka, pl. salkuna, scent b. wakiya, wakiyya; a large leathern $b$. for holding butter giwan basa; a small skin b. tandu.

bottom, 1. (the lowest part or foundation) gutsu, kalkashi, gato, e.g. b. of a fence gaton darni, gindi.

2. (buttocks) gato, gindi. bough, n. reshe, refe (S.), rehe, refo, pl. rassu, rassa, raffu, refuna; see branch.

bound, intr. v. (to leap up or forward) tuma.

bound, past part. 1. (tied up, fastened with a band) damrarre, pl. damrarru, aka damre, faskarari*.

2. fig. (obliged, required) wajib, wajibi with ne or ke, e.g. we are b. to go to the war wajibi ne mu tafi yaki. boundary, n. iyaka, gayya, or gaya (K.), kaida, makarin kasa, matuka.

bow, n. (i.e. the weapon) $b \breve{a} k \bar{a}$, pl. băkuna, b. and arrows băkan kibiya; to discharge a b., v. halbi or harbi; b. for cleaning cotton băkan shřba. bow,1.intr.v.(to incline the head in salutation) yinăfi,duka(S.).

2. (to b. down as in the native prostration) yin ăfi, gurfana, yin gurfane rusuna, sujada. 
3. to b. or stoop sunkwiya, sunkuya, sunkurya kurda (S.), duka.

(K.),

4. (to b. the head down or sideways in order to listen) karkata or kakartsa. bowels, n. hanji.

bowing, n., i.e. so as to touch the ground with the forehead sujada, sajada, alkafura ; see bow.

bowl, n. tāsa, pl. tāsoslii, gidauniya, gwongwon, kata*. bow-legged, chassa.

bowman, n. mahalbi, pl. mahalba or masu-halbi.

bowstring, n. tsirkiya, tsarkiya, chirkiya, igiyar baka.

box, n. akodi, akwati, sanduki, or sanduki, pl. sandukai, mai-sutura*; spec. a small skin b., e.g. for snuff batta, pl. battochi; barta, pl. bartochi; small glass b. for frankincense lulu.

box, v. dambe, nausha, naushe, nushe, dankwasa, dankwashe. boxer, dan dambe.

boxing, n. naushi, dambe.

boy, n. yaro, pl. yara, yaraye, yaye or yayaye; spec. b. who is third or fourth child, the previous children being all girls tanko*

boyishness, n. halin yaro. bracelet, n. tagula, tagulla,

R. H. D. tugula, tagura, munduwa,

pl. mundaye.

brackishness, zartsi.

braid, to tufka, tubka, tupka

(K.), tumka (S.); see plait. - brains, n. coll. kwalluwa, kwakxualluwa, ḳoḳolwa.

branch, n., of trees reshe, refe (S.), refo, pl. refuna, raffu; spec. small b. hamso*, b. stripped of leaves kututture, kututturo, kututturu ; withered branches coll. kwabruka; thin bending b. tsumanjiya.

brass, n. jan karife, farin karife, gachi, janjache.

brave, adj. mazakuta, da zuchiya babba, mai-zuchiya, mai-karifin zuchiya.

bravery, n. mazakuta, mazakunta, mazakuncli, tasiri (S.), zarumta.

bray, intr. v. (of the ass) birbira, barbara, yin kugi.

bray, tr. v. (to beat small, pound) daka.

bread, n. (made of wheat) gu rasa.

breadth, n. fädi, faski*. break, v. 1. tr. chiri; făsa, făso, păsa, fashe, pashe, palshe; kariya, kariyi, karye; kalle (K.), rotsa, roshe, rosa, tsinke, tsunke; to keep breaking tsuntsunke.

2. fig. to b. a promise saki 
alkawali or warwari alkawali.

3. fig. intr. of the day, daylight or morning, see dawn.

4. tr. with various modifications of meaning: to $\mathrm{b}$. open ribe, falke (S.); to $\mathrm{b}$. to pieces farfasha or palpashe (intens. forms of fashe, pashe), rugunguza*, farfutsa ; to b. off kudure; to b. up kakkariya, karereya, rusad da, balgache, kaririye intensive forms of kariya; to b. up again dandaka intensive form of daka; to b. off katse.

๊. to b. a horse birga, burga.

6. to b. the law tâka shari'a. breakage, aras, a sound as of b. garan-garan, kĭlin-ǩllin. breakfast, n. kalachi, or karin kumallo(also = midday meal), kariyan azumi, sahur; suhur. breaking, participial n. kariyewa.

breakwater, to hold water back by a b. datse; a b. used for catching tish gando, tăshi(S.). breast, 1. (bosom) kirji, pl. kiraza, kirijai, gaba.

2. (b. of mother or dam) măma, nono, pl. nonuna, nonaye or nonna.

breath, shortness of, n. fuka; to hold the b. dauki lumfashi. breathe, intr. v. lumfasa (S.), numfasa (K.), to b. heavily dauki lumfashi, yin sheda, I b. hard na yi fuka. breathing, n., heavy b. lumfashi, numfashi, lunfastu, sheda, habuma*, hambuma. breed, v. ba diya, yin diya, haifi, haife, haifu.

brethren, n. yan-uwa; my b. yan-uwana.

bribe, n. toshi; b. given to a judge fila or hila, kirsa, rishiwa.

bribe, tr. v. chidacheto*. brick, n. (made of mud) tubali, kunku (S.), pl. kunkaye; a grass used for making bricks ramno (S.), rauno (K.).

bricks, to make, v. yin tubali. bride, n., specially applied to the latest wife amariya; the state of a bride amarchi; the friend of a b. kqūwa.

bridegroom, n. ango, pl. anguna or angaye*; a feast for a b. and his friends ambaru$w a$, sansambi; a dowry or a gift given to a bride sadaki. bridge, n. kadarko.

bridle, n. lizami, lizzami, lizani, linzami; a strap round hurse's head fastened to $b$. maraya; a brass appendage to a b. peluwa; head of a b. kwalkwada, kwalkwali. 
brigand, n. mafashi; pl. only, masu-tari.

bright, adj. fari, fem. fara, pl. farari or farufaru; farifat, da tachi, tachache, pl. tachachu or tatattu; b. as silver tangarai, the last also $=$ unclouded.

\section{brightness, tachi, tăshi.}

brim, n. burbishi; up to the b. fau, e.g. it was filled to the b. ya hau fau, ya tashi fau. brimstone, n. faral wuta, kibrit*, kaule*.

bring, tr. v. kawo, kayo, kai; zo constr. with $d a$ (lit. come with), e.g. he brought the book ya zo da litafi; spec. modifications are to b. back (i.e. to restore) maida, tumbe ; to b. forth fíto da; (to give birth to) haifi or haife; to b. forward (to adduce) kai or kawo, e.g. b. proof kai shaida, they would b. forward a reason su kan kawo dalili; to b. near to the speaker, also simply b. here or b. near kawo; to $b$. together gabato, jawo; to b. up (to nurse, educate) gwoiyo, reno; to b. up a child or animal whose parent is dead tallafi; to take and b. tareyo or tariyo; to b. together jibche, jibta, tara. bringing, participialn. kawowa. brinjal, (tomato) gauta. brink, n. baki, pl. bakuna. brittleness, aras, gaushi, gau$t s i$.

broad, adj. fädi, da faski, bikiki, tafkeke.

broadcast, adv. a zube. brocade, n. dibajo, kambori*; white cotton b. samasadowa. broil, tr. v. soya or suya. broiled, past part. soyayye or soyeye, fem. soyayya, pl. soyayyu.

broken, past part. fasashe, pl. făsassu, kararre, matache*, or matache, fem. matachiya or matatta, pl. matattu, e.g. a b. vessel matattar Ķwariya, mara*.

broken, to be b. up, v. warwari, wariwari or wawa$r i$.

broker, n. dilāli or dillali, dan baranda; to act as b. yin diläli, or yin dilanchi; broker's commission, cf. seq. brokerage, n. (fee or commission as intermediary in sales) la'ada, ladda; if the price paid is to be la'ada chřki (b. included) the seller pays the b. (usually 5 p.c.), if la'ada waje (exclusive of b.) the buyer pays the $b$. brood, n. coll. (offspring) diya, 
in a wide or general sense iri, pl. irare, q.v.

brook, n. rafi, pl. rafuna or rafafuka.

broom, mashari*, tsintsiya; see brush.

broom-weed, sweet b.-w. roma fada.

broth, n. miya, romuwa (S.), romo (K.), kalu*; b. made from fruit of dorowa tree daddawa, daudawa.

brother, n. dan-uwa; used as an expression of regard in addressing others (usually with suff. pron. $n a)=$ brother! or dear friend! dan-uwana, pl. yan-uwana or yan uwa, shikiki, shakiki ; elder b. wa, pl. yeye; younger. b. ķăne, pl. kannai, or kanne. brotherhood, kanenchi.

brow, n. (forehead) goshi; he bent his b. or knit his brows (= he frowned) ya damre (gintse or jirkita) fuskassa. bruise, n. rauni, targade. bruise, tr. v. falfasa.

brush, n. tsintsiya, abin shara, mashari.

brush, tr. v. (i.e. to sweep with a broom or b.) shara, share, shache, kabe; to b. thoroughly kakkabe; to b. the hair shafa gashi.

brushing, $t s \bar{\imath} f a$. buck, n. prefix namiji, e.g. b. antelope namijin barewa; $\mathrm{b}$. goat bunsuru, pl. bunsurai ; water b. gwambaza; reed b. kaji, keji, kwantarafi. bucket, n. guga, pl. guguna, kwariyar guga; a leather b. wăsaki.

bucking, e.g. of a horse or donkey tutsu, butsari.

buckle, n. maballi.

bud, intr. v. yin gunda, yin tofo, kumpsa*.

bud, n. gunda.

buffalo, n., dwarf b. or bushcow bauna, pl. bakane, or baunaye; kutunkun bauna. buffalo-horm, (plant) magariyar kura.

buffet, v. buga, dambe.

bug, n. kazunzumi, gazunzumi (S.), kudi.

build, tr. v. gina, kafa; the former is also spec. applied to construction of roads, the latter to that of roof etc. with beams : kasantada*.

builder, magini.

building, a, n. garu*.

built, past part. ginanne, pl. ginannu.

bull, n. 1. (male of horned cattle) sa, bajimi (S.), bajini (K.), bijimi, bishimi, kinna : spec. large (castrated) b. burtumi, furtumi; b. for carrying 
loads takarkari, pl. takarkarai.

2. gen. (male of any large animal) toro, pl. toranni, torone, e.g. bull elephant toron giwa; toro with omission of giwa is often specially applied to the male elephant $=n a-$ mijin giwa.

bullet, n. harsashe, pl. harsasai ; harsa (S.), pl. harsashi, dutsim bindiga; see cartridge.

bulrush, shalla.

bunch, n. (e.g. a b. of flowers) dăme or dami, pl. dămuna or damma, dunji.

bundle, dăme, dami, dunji, gwallo; to place in bundles yin jeni.

burden, n. kaya, pl. kayayaki. burdensome, adj., see heavy and troublesome.

burial, abstr. n. biso, bizni, birni.

burial-cloth, native, n. zugu; see winding-sheet.

burial-place, n. makwanche, wurin bizne, wurin kushewa, wurin kusheyi, kusheya.

burn, v. 1. tr. łona, ḳone, ḳuna, soya, suya, surya, toyi, towi, toya, tuya; to b. up completely konkone, spec. to b. with a hot iron lalas*.

2. intr. Kuna, kone; fig. of desire etc., the heart burned zuchiya ta kuna.

burning, particip. adj. maifüra, lonewa; b. disease ḳona or kuna*; a smell of $b$. karni, Kasni, kaur.

burnous, alkyabba, pl. alkyabbu.

burnt, past part. Konanne, fem. konanna, pl. Konannu; spec. b. food, n. łamzo, Łanzo; b. all over, adv. kurmus*. burrow, to raraka, raruke. burst, v. tr. and intr. fashe, pashe; bursting out laughing fashewa da dariya; sounds of bursting (onomatopœic) fus; to b. open tsiyayye (K.).

bury, tr. v. bizne, bisne, birna, busa, bushe, binne*, turbude, turumbude*; spec. to $\mathrm{b}$ in the earth as locusts do their eggs turbude.

burying-place, n. see burialplace.

bush, n. spec. thorny b. Kwabdodo, kaudodo, sarḳakiya ; thick-foliaged b. used as food sukuki*; b. in the sense of uncultivated forest land daji, rukuki; b. in sense of scrub or farm b. jeji, kunchi, kumchi. bush-buck, lesser b. or 'harnessed antelope' (i.e. Tragelaphus scriptus) m(ızo, ganjar. bush-cat, see cat. 
bush-cow, or dwarf buffalo bauna, pl. bakane, baunaye. business, n. 1. (trade, commerce) chiniki, shăgali, pl. shagulla (S.), or shagulgula (K.), bukāta, sha'ani; to do b. yin shăgali; to do b. with yin da.

2. gen. (= concern) bukata; also, in neg. and interrog. sentences, ruwa, e.g. it is no b. of mine ba ruwana or babu ruwana, what b. is it of yours ina (lit. where?) ruwanku? go about your b. ka tafi abinka; minding one's own b. sha'ani; mind your b. shiga sha'aninka; he went about his b. ya yi zamansa.

3. (affair or thing) $a b u$, e.g. a bad b. abin mugu.

bustard, the lesser b. kadabkara, kadafkara, sokara* ; the greater b. tuji.

busybody, mai-kwarmato.

but, 1. adversative conj. amma; $d a$ is at times found where the opposition is not (as with amma) explicit and logical, e.g. but are you able to do this? da kana iya yin haka? fache*, balshe*, bari dai.

2. exceptive prep. and conj. sai, e.g. a woman's entire body ought to be strictly concealed but the soles of her feet and her eyes jikin mache duk yi al'aura ya ke sai ko matakai sai ido; those who love thee can but salute again masowa naka sai kuma salmawa; neg. there is no health in it, nothing but sickness babu lafiya chiki nata sai chiwuta; there is often an idiomatic ellipsis before sai, e.g. the whole street was nothing but water dukan kasuwa sai ruwa, nothing but blood sai jini; in this way is to be explained the phr. sai lafiya, i.e. nothing but well, i.e. quite well. The expr. bamda or banda may = English but, e.g. put nothing in the pot but meat kada ku sa komi chikin tukunya bamda nama where sai nama would be equally correct.

butcher, n. mafauchi, mahauchi, pl. mahauta.

butcher, tr. v., i.e. to slaughter anirnals in technical sense yin fawa.

butcher-bird (shrike), bambami.

butchery, n. tech. (slaughtering of animals) fawa.

butt, intr. v. kăra, yin kăro, tunkwiya, tunkuda, e.g. the two goats are butting each 
other awaki su biyu suna tunkuda junansu or da juna. butter, n. 1. gen. whether animal or vegetable mai.

2. cow b. main shanu, dunguli, dungule, turde; a large leathern bottle for holding b. giwan basa. butterfly, n. bamota or bamawuta, kwalkwala, kilikili, kilkili; the expr. litäfin Allah (writing of God), or dokin Allah (God's horse) is often used to designate the butterfly ; cf. tadawal Allah, malam bude litafinka.

butter-tree, n. the shea-butter tree (Bassia Parkii) kadanya; shea-butter, i.e. its thick butter-like oil, main kadanya, main kade, or man kade.

butting, n. kăro, tūni, tunkwiyi.

buttock, n. gato.

button, n. makubli or makulli, pl. makublai, mabantari (K.), mabantali $(\mathrm{S})$, maballen riga, anini*.

buy, v. saya, sayi, saye, sai; to b. and bring back sayo; to be bought sayu.

buyer, n.mai-saye,pl.masu-saye. buying, sayi; espec. wholesale b. făja; b. and selling saye da sayarwa, or saye da sayaswa. buzz, n. amo; b. of bees kugi, kogi.

buzz, intr. v. amo or yin amo. by, 1. prep. instr. (with) $d a$, e.g. he was struck by an arrow aka halbe shi da kibiya.

2. prep. loc. (near) kusa, kusa da, or kusa ga, e.g. by the shore of the pool kusa ga bakin gulbi; (along by) baya, e.g. we walked by the town mun yi yawo bayan birni.

3. prep. distributive, e.g. by fours fudu fudu, by tens goma goma.

4. adv. (near) kusa.

by-and-by, an jima and zuwa zurva.

byword, ef. her character became a b. halinta ya zama sara.

cackle, intr. v. yin karkara. cackling, n. kyarkyara, kirkira. cactus, a prickly Euphorbia with c.-like habit and milky juice tinya, tunya, kyarana. cadger, bakanchi, maichile, masha-chile.

cage, n. akurke, akurki, pl. akurkai, gidan tsuntsuwa; a cage for fowl (a hencoop) akurkin kaza.

cake, n., c. of rice or guineacorn waina (K.), tsala, tsaliya (K.), tswala (S.), māsa (Zaria); 
c. of wheat flour and honey fankasu; c. of bean flour and oil soto; c. made from beans of the dorowa tree daddawa; c. of oil, honey and rice or wheat tsatsafa, bankuru, bakuru, kosai, shashaka.

calabash, n. gora, pl. gorina, kwariya, burmi, gyandama, maburmi, muburmi; spec. small c. kumbu ; long-necked c. used as water-bottle kurtu, kortu; c. finger-basin kwachiya; c. strainer rariya; a small c. placed in a water pot to prevent water spilling when carried magumki, gumkaruwa.

calamity, n. (distress, adversity) tsiya, masĩfa, mayãta, wahala; a c. (a distressing or adverse thing or event) abin mugu or mugun abu. calculate, v. (to compute, reckon) yin kidaya, kilga, kirga, yin lisafi.

calculation, n. 1. (act of computing or reckoning) kidaya, kida, kididdiga.

2. (sum or amount reached by c.) kidaya, kida, kididdiga. lisafi, the last commonly applied to accounts, bills, etc. ; beyond c. (incalculable, innumerable) sun $f i$ kidaya.

caldron, n. tukunya. calf, n. 1. (young of large animal) $d a$, connective $d a n, \mathrm{pl}$. yaya or ya, connect. yayan or yan, coll. pl. diya, connect. diyar.

2. (young of cow) marăki, fem. marăka, pl. maruka or marukka; spec. \& young female c. karsana.

calf, n., i.e. of the leg dambubu, tukatukai* (K.).

calico, n. alkāmura; white c. for making tobes mahamudi, alawayo (S.).

call, tr. v. (to summon) kira, ǩ̆raya, kiraye; to c. or summon to where the speaker is, and also simply to c. kirawo; to c. in the sense of to name kzra suna ; 'called,'. i.e. named or entitled is expressed thus : a man called Bube wani mutum suransa Bube, a great man who was called the Madaki baba ana che da shi Madaki; calling out, verbal n. kira; one who calls to prayer makiran salla. callous, dakanta.

calm, n. (absence of wind, still weather) natsu, natso, natsu$w a$, nitso, nitsuwa, also used fig. in the sense of relaxation or rest.

calm, tr. v. (to appease) lallashi or lillashi, sanyaya. 
caltrop (plant), tsaidau, tsidau, dayi; water c. gyadar ruwa. calumniate, v. chim-baya, rada*.

calumny, n. chimbaya, rada. camel, n. rakumi, fem. rakuma, pl. rakumma; the female c. taguwa, pl. taguwai, taguwoyi; spec. large male c. amale; a two-humped camel aturkumami, f. aturkumama; a running c. jeraya; the constellation of the C. $t a$ guva.

camp, n. 1. (halting ground of travellers etc.) zango, pl. zanguna.

2. (in the military sense) sansani; camping-place, $\mathrm{n}$. wurin sabka or sapka.

camphor, n. käfur.

camwood, majigi.

can, auxiliary v. iya, also samu; he could not enter $b a$ ya samu ya shiga; with passives a iya may be employed, e.g. it cannot be lifted $b a$ a iya a dauke shi.

cancel, to c. an agreement warware.

cane, n. 1. gora, pl. gorina; spec. water-cane burgu; sort of bamboo c. kwangi, kwagiri; sugar c. takanda, rake.

2. (walking-stick) sanda, pl. sanduna, kulki. cannibal, n. 1. jan-maye, maichin mutane.

2. c. people, or tribe yamyam, nyamnyam.

cannon, n. madafa*, agua. canoe, n. jirigi, abara*, jirgi, pl. jirage; c. cover rumpa, komi* (S.), rumfa; c. paddles filafile or fulafule; c. paddle used as a rudder matuki; a c. pole gwangwala*, kwargwala. canoe, to paddle a c., v. tuka, the participial $n$. of which is tukawa.

canter, n. hammadanchi.

canter, intr. v. zugurubtu, jigeribti, jigribti, kwakkwafa. cantle, of a saddle kwachiar baya.

cap, n. tagiya; spec. a white c. worn inside fez füla, pl. fuluna; a blue or black c. fŭla saki; c. of red cloth with tassel (fez) fuladdara, fulandara, faladara; a c. with two flaps to cover the ears hăbal kăda.

cape, made of palm fibre kabido, kabudo. capsicum, barkono. capture, tr. v. 1. (to catch or take, of prisoners, slaves) kama, kankama, same.

2. (to conquer, get dominion over a city or people) chi, e.g. he conquered the people, the 
king was captured ya chisu aka kama sariki; to c. and bring back chiwo.

caracal, (lynx) dage.

caravan, n. ayari; the chief of a c. jaji; head-man of a c., who walks behind it $m a$ dugu, pl. madugawa; guide or forerunner of a c. jāgăba or shŭgaba; the tax paid by a c. for permission to travel kurdin boda, făto, fúto; a collection of caravans kăăfar fatake.

carcass, n. gawa, pl. gawawaki.

card, to c. cotton shịba. cardinal-bird, the scarlet mulufi, malufi.

cards, playing c. yaya*. care, n. 1. (heed) ruwa in neg. and interrog. clauses, e.g. what c. of mine is it? ina ruwana? hankali, which also has the sense of forethought.

2. (anxiety) matamache*, e.g. the cares of the world matamachen duniyan nan; see sorrow.

care for, v. (heed, regard) waiuaya, kŭla or yin kŭla, tara, tsēre; to c. for (to pay attention to and so beware of) tuna, yin hankuri; all of these verbs except the first govern an object by means of prep. $d a$, e.g. he cared nought for his reproof bai kǔla da foronsa ba.

careful, adj. (heedful) mai-hankali; be c.! hătara, hŭtara. carefully, adv. 1. (heedfully, prudently) $d a$ hankali.

2. (attentively) sărai, e.g. look c. $d u b a$ sărai.

careless, adj. (imprudent) $m a-$ ras-hankali, bizki; (inattentive to work) mai-lalachi.

carelessly, adv. babu hankali, da lalachi, da lalafanchi, da sakafchi; to act c. through absence of mind shagalchi.

carelessness, n. 1. (want of care) sakafchi.

2. (indifference, idleness) lalachi, lalafanchi.

caress, n. lalaba.

caress, v. yin lalaba.

cargo, n. kaya.

carpenter, n. măsassaḳi, pI. masassaka; shop. of a c. masaka.

carpet, n. kilishi*. carriage, karusa*.

carrier, n. gen. mai-daukan kaya; spec. hired c. dan aläro; head or chief c. sarikin alāro; a trader who carries. his goods on his head dangurumfa, bojuwa, bujuwa, maikaya; money paid to carriers sufuri, sufurchi; an epithet 
applied to a carrier who keeps putting down his load maibari.

carrion, măsai, mosai, mushe. carry, tr. v. kai, shidi, the latter constr. with $d a$; to c. in shiga da, shigo da (lit. to enter with), nothing shall be carried tied up into the town of Zaria ba a shigo da komi a birni; to c. on (transact) $y i$; to c. off tafi $d a$; to c. through (accomplish) iyas, iyas da. cartridge, harsa, harsashi; c. case kamsir, kurfi, kwanso, kwasfar harsashi; see bullet. case, n. (receptacle, cover) gida, e.g. needle-c. gidan alura; spec. leathern c. for holding a book găfaka, gŭfaka.

case, n. 1. (state or condition) zama.

2. (event, thing) abu, e.g. a bad c. (i.e. a bad business) mugun abu.

\section{cassava, rogo.}

cast, tr. v. jefa, jefi, jefo; to c. aside yas da, yadda, yashe; to c. out (throw out) jefa $d a$, jefas, jefas da, jefsa*, jefshe*; (to expel as from the mind, the throne, etc.) fidda, fita with $d a$, fishe, e.g. he was c. (or driven) out aka fitad da shi or aka fishe shi; to c. up (to reckon), yin lisafi to c. the young bari ; cf. haifuwa bari still-born; see calculate.

castigate, tr. v. 1. (punish) fallasa, pallasa.

2. (beat) buga, bubbuga. castigation, n.1. (punishment) fallasa, pallasa.

castor-oil, (plant) zurma. castrated, tauri*. castration, fidiya, pidia. casualty, see accident. cat, n. muzuru, muzulu, mazuru m., fem. kanwa or kyanwa, pl. kyanwura,kyanwai, măge, mussa, mŭsa, pl. mussoshi, mussai (S.) ; spec. tortoiseshell or spotted c. tsawarwara; tabby bush c. tsara; civet-c. jibda, măgen tantal, muzurun juda, muzurun tantal, kyanwartantal,tunkun jibda; African palm civet or genet madadashi; wild c. jimolo, baudari, tunku, wazagi (S.) ; serval-c. rabji, rabi*, robe*, inyawara.

cataract, n. (or corneal ulcers) hakiya or hekiya, tsauriya, tsawuriya.

catch, tr. v. kāma, ruski, chăfa, chăfe, sarḅe; to c. a cold, e.g. I caught cold sanyi ya kama ni (lit. the cold caught me); to c. up chřka $d a$; catching chăfiya; to $\mathbf{c}$. intr. (of a fire) habaka. 
caterpillar, hairy, n. ğ̌zāka, gisaka, kisāka*, tsutsa, gamatoro; an edible c. tsarna; a light green c. wutan ganye. cat-fish, gondo (S.), kulume, mari, kurungu; electric c.-f. (Malapterurus electricus)minjiriya (K.), mijiriya (S.). cattle, n. coll. dabba or dabbo, pl. dabboni or dabbobi; (cows) shanu; c. disease bingiri; humped c. jăba-jăba ; c.-shed garke, gerke, garge (S.) ; a - place for feeding c. makiyaya; a Fulani c. camp rugga. caught, particip. adj. (of a fire) gasashe, fem. gasashiya, pl. gasasu; to get c. in falling sage.

caul, rigar haifuwa.

cause, n. 1. (origin or ground) gutsu, sabăbi, sanadi; without c. babu sabăbi.

2. (reason adduced in proof or explanation) dalīli, sabili, hamzari, e.g. they give a c. (i.e. a reason for confidence) and an excuse su kan kawo dalīli da huja; hence often applied to texts from the Koran.

cause, tr. v. $s a, b a$ or bada, maida, yi, rataya*, tāsăda* ; theseareconstrued as follows: I caused him to laugh na ba shi dariya, he caused me to fear ya ba ni tsoro, he caused him to sleep ya sa shi shi kwanche or ya maida shi shi kwanche.

causeless, adj. babu sababi, kakarai.

caution, n. (prudent care) hankali.

cautious, n. da hankali; to be c. yin hankali.

cavalry, n. barde, pl. barade;

c. with shields garki or garikine; collection of c. kangar*. cave, n. kogo, pl. koguna, maraya*.

cease, intr. v. daina or dena, e.g. she did not c. ba ta daina $b a$, tr. she ceased crying $t a$ daina kuka; the rain ceased ruwa ya dauke.

ceaselessly, adv. kul yaushe. ceil, tr. v. yāba, yā bẹe.

ceiled, particip. adj. yabaḅbe, fem. yaḅaḅa, pl. yabaḅbu. ceiling, damren-guga, daurenguga.

celebrate, tr. v. (to praise, honour) yin yabo.

celebrated, particip. adj. yab$a b b e$,fem. yababba, pl. yababbu. celebrity, n. yabo.

celestial, adj. mai-sama, spec. applied to God.

cement, (used in making roofs)

babarkiya, katsi.

cemetery, n., see burialplace. 
centipede, n., a harmless c. shanshani, sonsoni*, pl. shan shanu, aimaka (S.), daidaya; see millipede.

centre, n. tsăka, tsăkiya; spec.

c. of the inside of thatch roof kwando.

certain, adj. 1. (assured, true) e.g. c. (i.e. true) words magana tabbatachiya; are you c.? ka tabbata? ka tabbata or ka shaida; to be c. sakankanche, tăbata, tăbache; to make c. yin tabbas, wajabta.

2. (one, some) wani, fem. wata, wota, pl. wadansu, wansu, wasu, wosu ; cf. a 2.; to express a c. person known but unnamed (= so-and-so) $k a z a$, e.g. a c. person passed mutum kaza ya wuche.

certainly, adv. da gaskiya, an che, hakika, lābudda, labuddi, tabbas, takar (K.) ; c. is expressed also by means of tabbata, e.g. he is c. there ya tabbata nan, babu shakka. certainty, n. gaskiya. certificate, n. lāya*. certified, particip. adj. shaidadde, fem. shaidadda, pl. shaidaddu.

certify, v. hakikanta. cesspit, n. salga, pl. salgagi. Chad, pr. n. of lake, Tsada or ruwan Tsada; see Benué. chafe, intr. v. (to feel irritated) jin haushi; he chafed at this. ya ji haushin wannan.

chaff, n. dusa (K.), dussa (S.), kaiḳai, soshiya, kona ; small piece of c. tsinki.

chagrin, n. haushi.

chain, n. sarḳa, salka, pl. sarkuna or sarkoki; coll. chains sasări; c. armour sulke.

chair, n. kujera, kushera*.

chalk, n. aljŭbus, alzžbus; chalk or white earth used for bleaching thread alli.

chamber, n. daki, pl. dakuna; very small c. or closet loloki, pl. lolokai.

chamberlain, n. madaki, madaiki.

chamber-pot, shăda.

chameleon, n. hawainiya (K.), hawaniya, hanwawa (S.).

champion, gamzo.

chance, n., see accident, opportunity.

chance, impers. v., it chanced ya faru.

change, v. 1. tr. and intr. sauya, sawaya, sawoya.

2. tr. maida, maishe, musaya, musayi, musaye; to c. one's mind sake shauara, sāke, saki.

3. intr. mayas da, rikŭda, jirkita, the last referring to 
any c. of position whether material or figurative; e.g. he changed his body ya sauya or sawaya jikinsa, I changed to a moslem na sauya musulmi, the king has changed (the value of) the Spanish dollar sariki ya maida kurdin madafa, my master changed my wages ubangijina ya sake ladana, I am changing into some creature or other ina rikida wani abu, I changed myself into a bird na rikida tsuntsuwa, they changed sides sun swaba juna.

change, n., e.g, of money kwaro, chǐko; (alteration) jirkita.

changed, particip. sauyaye, fem. sauyaya, pl. sauyayu; sakakke, fem. sakakkiya, pl. sakakku; rikidadde, fem. rikidaddiya, pl. rikidaddu.

changing, participial n. $s a$ kiwa, sauyi, jirkitawa, for the application of the latter cf. jirkita under change.

chapping, e.g. of skin făso. chapter, n. (division of a book) kai, sura*, pl. surori*, e.g. the tenth c. kai na-goma or sura ta-goma.

character, n. 1. (disposition) hali, e.g, such is his c. halinsa shi ke or halinsa ke nan; tabi'a, dabi'a.
2. (good repute) suna; he bears a high c. sunansa nagari ne; see fame.

3 . to have a certain c. is expressed by means of the $v$. tarika, e.g. he is a quarrelsome c. (he is always quarrelling) ya tarika fada.

characteristic, n. hăli, pl. hălaye; theft is a c. of the thief sata hălin barawo.

charcoal, n. 1. gawayi, pl. gawaye, not used of burning c. for which cf. 2 .

2. burning c. garwashi, p]. garwashoshi.

3. charcoal-tree, a small tree kiriya, from which is made smith's c. garwashin kiriya.

charge, v. 1. (to load) cȟ̆ka or dora, e.g. they have charged their guns suka dora bindiga.

2. (to command) hakumche, hakumita.

3. (to rush on, to attack) fadi (bı̌sa, b̌sa ga or) a bı̌sa. charity, n., see alms.

charm, n. 1. gen. whether written or of any other kind māgani, lāya, pl. lawaye, layu ; hatumi, katumi*, sakatubu*, bara, talili; sunan Allah (lit. the name of God), this is used of various charms 
which are written on a smooth board, the ink from which is washed off and swallowed.

2. spec. a c. to promote a successful deal tsārăka; stone c. for woman's neck kandu or kandun ido; c. against injury in war layan sabani; an inverted c. placed in a field as a charm against thieves kwanda, kunda, tsā $f i$; love charms tsibbu, mantawa*; c. to render anyone invisible lāyar zana; c. to ward off arrows sha bara, lāyar sabani; injurious c. sammu or sammo ; see also trra.

charmer, snake-, n. gardi, pl. gardawa, turde, pl. turdawa.

charms, 1. to write c. tsubbu; one who writes c. mai-tsǔbbu; one who utters deadly c. maita.

2. (female attractions) see beauty.

chase, n. (hunting) farauta. chase, v. 1. (to hunt) yin farauta.

2. (to drive away) kore.

chaste, adj. tsari.

chattels, urula.

cheap, adj. da araha, da arha; it is c. shina da araha; a c. sale gwanjo.

cheapness, n. araha, arha. cheat, n. 1. (fraud) kura, riba, rikichi.

2. (one who cheats) machi kūra, pl. machiya kūra ; maichinkura; mai-riba, pl. masuriba or mai-riba da kura; mai-zambachi, mai-zambata. cheat, v. chin kura, chin riba, rikiche, rinta, zambache, zambata, săfa (S.), zartara.

cheating, n. kura, hayinchi; see prec.

check, v. 1. (reprove) kwaba.

2. (hinder, restrain) hăna. cheek, n. kumchi, pl. kumatu; hair on the cheeks saje; a man with fat cheeks dan kumatu. cheer, v. bada murna, yin murna.

cheese, n. chukumara, chuku. cheetah (or hunting leopard), rabbi, gundumau*.

chew, v. tr. tamna, tona, tauna, tsuke, tŭke, e.g. we are chewing kola-nut muna tamna goro.

chewed, particip. tamnanne, fem. tamranna, pl. tam. nannu.

chewing, n. tamna, tš̌ko (K.), tsuku.

chew-stick, (i.e. name of trees) marke, marike, tafashiya. chicken, n. dan tsăko, tsiyako, pl. yan tsăko.

chief, n. bagare, pl. garewa, 
$b a b a$, e.g. he is their c. shi ne babansu, also in. sense of a c., a great man; sariki, often in the sense of head or president of any body, trade etc. ; ido (lit. eye) is used in poetry thus, behold Bello, chief over his kingdom $d u b a$ ga Bello idon malki nai; turuari*; see under fadawa. child, n. 1. (son or daughter) da, connect. dan, fem. diya, pl. yaya, yayaye and ya, connect. yan.

2. (young person) yaro, pl. yara.

3. a very young c., an infant up to one year of age jariri, jarili, yarili, jinjiri ; spec. c. carried on a woman's back bumbu, goyo, goiyo; a c. which dies soon after birth dan wabi.

4. with c., see pregnant.

childhood, n. yarinta, yaranchi (K.), yarantăka kurichiya, ḳuruchiya.

childishness, n. halin yaro, halin kankanta, kuruchiya or kcurchiya.

chill, n. funturu, especially that felt at night.

chillies, barkono.

chin, n. hăba, pl. hăboba; double

c. maroro or malolo; the lower part of the c. leke (S.).
China, n. geogr. Sin*.

chip, to c., e.g. with a hammer kwarsana.

chisel, n. kurufi*, furufi*.

choice, zabe, zabi, 'zabantaka, zabanchi.

choke, tr. and intr. v. mākŭre; to cause to c. sumanche, sunanche.

choking, due to swallowing anything, n. māḳ̆ra, l̦wăra*. choose, v. zaba, zabe; spec. to

c. out one or more pieces of anything (to select) wari. chosen, 1. pass. v. zabu.

2. particip. zababbe, fem. $z a b a b b a$, pl. zabaḅu.

Christian, a, n. annasāra, also used as coll. pl. Christians; to become a C. nasaranta. Christianity, n. addinin annasara.

church, i.e. a place of worship,

n. masallachi, pl. masallatai. churn, v. burka, burga, tunkwiya nono.

churning, tuguwa*. cicatrice, n. tambo, tabo. cigarette, stump of a guntun taba.

cinders, n. garwashi, pl. garwashoshi; garwashin wuta. circle, n. bukāri*, l̦awanya (K.).

circling, of a bird over its prey jewa, shawāge. 
circuit, to make the c. of, tr. v. kewaye, kewayi, yin kewaye; see under round.

circumcise, v. yin kāchiya or yanke kāchiya, sălasăd da(S.). circumcision, n. kächiya, salasuwa, sha.

circumspectly, dubanan dubanan, lekanan lekanan. cistern, large, n. bingi, kurkŭddufi, kunduddufi or kududdufi; a c. for collecting rainwater kwiyaka, kuyaka.

citizen, n. dan-gari, pl. yangari.

city, n. birni, pl. birane or birnuwa, used of large and walled towns, while gari, pl. garuruwa, garuruka and garigaru, is applied to less important and to country towns. civet-cat, n. jibda, juda (K.), magen tantal; frankincense obtained from the c. turare. civil-war, basasa.

claim, n. alhaki, e.g. the c. of one defrauded.

claim, tr. v. (to demand as one's own) nema, e.g. I claim my own ina nema abin nawa; to claim a debt bim bashi; cf. $b i$.

clamour, n. (loud outcry) kururuwa, lŭmi, surutu (S.).

clamour, v. (to cry aloud) yin kururuwa.

R. H. D. clan, n. dangi, pl. dangogi; iri, pl. irare.

clang, the c. of metal on metal kyang.

clap, v. (to strike the hands together in applauding etc.) tāfa or yin tafi(K.), yin tabi (S.), ban hannu.

clapping, tafi, taḅi (S.).

clarify, by straining, tr. $v$. tachi.

clasp, n. ḳugiya.

clasp, v. (to embrace) rungume. claw, n. of an animal, akaifa, dayi.

claw, to yayaga; see scratch. clay, n. yimbu, yumbu, yambu, e.g. they are built of c. an gina su da yimbu; a lump of c. burugushe* or burbushi*; a yellow c. used as a dye for women's faces dāla; white c. karmatako, karmantako (K.); a hard c. soil kekuwa.

clean, adj. 1. gen. sărai, of wheat chari or tsari.

2. (ceremonially and so also morally c., pure) halal, halas, tsari or chari.

clean, tr. v. e.g. with water darwaye, lariwaye*, kwăla, kwarkware (S.) ; of the hair, garments etc. tsabta, cf. wanke; (to scrape off, c. off) gogi, goge; to c. from husks surfe, surfa; (to render c.) yin sarai, 
maida, sarai, gyarta; to c. the teeth lavalkwale; to c. raw cotton shùba.

cleaned, particip. gyartache, fem. gyartatta, pl. gyartattu; wankakke, fem. wankakka, pl. wankakku; c. from husks etc., of rice, shanshere, surfaffe.

cleaning, of cotton shịbi.

cleanliness, n., of the person, clothes etc. tsabta, tsapta.

cleanness, n. karari; esp. in a religious or moral sense tsar$k i$, tsalki ; cf. seq.

cleanse, tr. v. (of the heart) tsarkaka or charkaka.

clear, adj. 1. (of liquids, the sky etc.) da tachi, tangarai, tangaran; the sun looks like clearing gari yaishirin sarari.

2. (manifest, plain) zahiri, sărai, ḷwarai.

3. (pure, irreproachable) tsari or chari.

clear, tr. v., to c. ground before ploughing, săsabe.

clear, to make, tr. v. (to explain) waye, e.g. this matter is difficult, I wish you to make it c. to me abin nan da wuya ina so ka waye mini.

clearing, c. ground for sowing $z a f a$ (S.).

clearly, adv. (nanifestly, obviously) sărai, ḳwarai.

clearness, tachi. cleave, tr. v. (to cut with a blow) sare.

cleave to, to, intr. v. rike, like, rika, kakkafe, riki, dăfe.

clerk, akawu.

clever, adj. 1. i.e. in an art or profession gwani, goni, pl. gwanaye, gwannai.

2. gen. (astute or cunning) shaitan, i.e. as c. as Satan.

cleverly, adv. (cunningly) $d a$ wayo.

cleverness, n. 1. (in an art etc.) gwaninta.

2. gen. azanchi, budi, hikima, fahimta.

click, made with tongue or teeth, a sign of vexation kwafa, kyache (S.).

climb, v. hawa or hau, e.g. he climbed the hill ya hawa dutsi or ya hawa brsa dutsi. clitoris, filaniya, tsele.

cloak, n. alkyabba, pl. alkyabbu, riga*.

cloak, tr. v. 1. (to put on a c.) sa alkyabba.

2. (to conceal) rufe, rufi or rife.

clock, n. sa'a, lotu*, loto*. Hausas who are acquainted with clocks express 'o'clock' thus, three o'clock sa'a uku; half past eight o'clock $s a^{\prime} a$ takwas da shashi; karife is 
also used in describing the time, as the hours are often marked by beating iron, thus, what time is it now? karife nawa ne yanzu; it is two o'clock ya yi ḳarife biyu.

clogs, wooden dan garafai (S.). close, v. 1. tr. $s \bar{a} d a$; to c. a door, box etc. rufe, rufi or rife, like; to c. the fist tankwashe; to c. a hole done, danne, dăne; the door is closed (also in fig. sense) an rufe lofa.

2. to c. with, used of a bargain or agreement yarda. close by, adv. kusa, daura $d a$, dubbara da, dabda, dafda, dabrada.

closed, particip. (fastened up) girkakke, fem. girkakkiya, pl. girkakku; cf. phr. the road is c. hanya ta mutu.

loset, bayan gǐda, makewaye ; (small room) loloki, pl. lolokai.

loth, n., spec. names of stuffs are: blue c. shudi; blue, shiny c. turkudi, pl.turkudda; c. formed of blue and white strips keke; native blue or black c. with silk inwoven ridi; black striped c. from Ilorin bunū; a black and white women's c. zalwani; a coarse white c. gwado; a c. with white stripes gwanda; a white c. with red stripes gorori (K.) ; a black and red c. kudi; a c. with alternate strips of two colours luru; a variegated c. zaura, zawara or idon zaura; variegated c. used for turbans barmushi; a kind of velvet c. yapki, karamiski, kadamiski; a red c. shāli; a whitenativec. alfinti, dimi*, zauwati; a c. that has no seam in it liwăsa; woollen c. mulufi or malufi; a brocade c. worked with gold inside dibajo; (a piece of c. used in various senses and spec. = Engl. 'a cloth') a loin c. bante, banche, pl. bantuna ; a shoulder c. lěki; a small piece of c., a c. kalkafi; a woman's c. zăne, pl. zannuwa or zanna, gyauto (K.); c. gusset in a tobe shiga; a strip of c. zugu; a piece of c. made of about twenty strips wawa; a roll of c. turumi; long strip of c. ausagi; a single thickness of c. palle; a double thickness of c. rǔbe, rị̆i, ruḅi; a narrow strip of c. fari; a blue pepper and salt pattern c. zabako, saki, swaki; a narrow silken line in c. barage; a breadth of c. between two seams chiki; a professional 
c. hammerer mubugu, mu- , bugi, mabugi; see also barbaro, hamakūku, mai-sanda-a-chi-goriba.

cloth-measure, n. cubit kāmu;

$8 k \bar{a} m u=1$ zăne, the last= about $15 \mathrm{ft}$; ; a short length of cloth kyalle.

clothe, tr. v. sitira, sutura and sitirta, tufata, tufasad da; sa (lit. to put on or upon), e.g. to put on one's clothes sa riguna; e.g. the brokers who have made unjust profits shall be clothed with garments of fire dillalai fa masuriba da kura a sa ma su riguna wuta.

clothes, n. (i.e. clothing) $t u$ fuwa; coll. tŭfa as well as its pl. tŭfafi; riguna; spec. beautiful c. sutura, sitira, haiba*, abin rufa; fine, expensive c. kambi*; old c. keso, tsumma, ragga (S.). clothing, n., e.g. fine c., beautiful c.; cf. prec. cloud, n. habaki*, pl. habaka ; special names are: moving c. gilgije, girgije, girigiji; small white, still clouds lumshi; a c. that produces a shower zirnaniya, jitau; clouds coll. gajimare, gashimare*; to rise in clouds like smoke turnike; the dust rose in clouds laura ta turnike.

cloudy, adj. expr. by da with prec., e.g. da lumshi. cloven, particip. rababbe, fem. rababba, pl. rababbu. cloves, n. coll. kanumfari, kanunfari, hanchin kade (S.).

club, n. gwami, guduma, pl. gudumai; a c. for throwing kere.

coal, n., see charcoal. coat, n. 1. riga.

2. c. of mail made of cloth and padded with cotton, wool, etc. lifidi; a white cloth c. gwado. coaxing, lallāshi, rarrashi. cobra, (Naia nigricolis) kumachi, kumurchi, kwamachi, kwamarchi, sarikin machizai. cobweb, zaren gǐzo, tautauchi, yana.

cock, n. 1. (male of poultry) zakăra, pl. zakăru; mai-chara, mai-chara.

2. to express precisely the male of birds miji or namiji (hen mache) must be used where the gender is not denoted by different words. cockroach, n. kyankyaso, ka. fata.

cocoa-nut palm, kwakwa attagara. 
coerce, tr. v. 1. (restrain) hăna.

2. see to force.

coffee, n. gahawa, gahwa.

cogitate, v. tuna, the obj. of thought is constr. with $d a$ or ga.

cogitation, n. tunane. cohabit with, v. gamu da mache.

coiffure, a helmet-shaped c. worn by women kitso.

coil, intr. v. năde; intr. and refl. to c. up nădu.

cold, n. 1. d̄äri, sanyi, sansanya; I feel the c. or I feel c. irca jin dāri.

2. (catarrh) dāri, mājina, masassara*, mura, sanyi, e.g. I have caught c. or a c. $d \overline{a r} i$ (or sanyi) ya kama $r i$; a man with a c. in the head maishako (S.).

3. spec. c. felt at night funturu.

4. the c. season funturu. cold, adj. dệri, àa dāri, da sanyi; it is c. ya yi dāri; e.g. c. water ruwan dāari, ruwan sanyi, sanyin ruwa, they are c. suna da dāri; to be stiff with c. sandare.

colic, tsamki.

collapse, v. to afka, auka, abka. collapse, I collapsed na fadi reran, or na fadi warwar. collar, n., spec. a padded cloth collar used in war to protect the back of the neck dagumi; to seize a person by the $c$. dagume.

collar, to make a kalmăsa, kalmisa (S.), kalmashe.

collar-bone, alan gaba, alan kafada.

collect, v. 1. tr. tāra, tarshe, jibche, jibta; spec. to c. a debt biyo bashi, dauki bashi.

2. intr. taru, an tara.

collected, particip. tararre, fem. tararra, pl. tararru.

collection, n. (of men and things) taro or taru, pl. tarori; tsibi; chushe.

collector of taxes, n. jakā da*, jekāda*.

colloquy, n. zanche.

colour, n. launi, pl. launoni, launoka, rini or rina, jinsi (S.) ; blue c. shuni or juni* coloured, particip. tǔrarre*, fem. tйrarra*, pl. tŭrarru*. colt, n. tlan dukushi or dan dukkushi.

comb, n. masarchi, mashacli, matsefa,matsefi, masoshi, shata. comb, c. of a cock tsoro.

comb, tr.v. gyarta, tsefe, tsatsefe, shata or shache, tsĕfi, e.g. I am combing the hair of my head ina shata gashin kaina. combing, $t s \bar{v} f a$. 
come, intr. v. $z o$; (used with pronominal forms ending in na) zuwa, zaka ; tafo or taho*, e.g. c. to me zo or tafo ma $n i$, but when used to invite attention or cooperation yaka, fem. yaki, e.g. c. ! let us sit down and converse together yaka mu zamna mu yi zanche tare; we came to a city muka zaka ga wani birni. Some idiomatic combinations of $c$. with preps. etc. are: to c. about or to c. to pass faru; to c. at isa, ishe, iske; to c. back dawo, dawayo, komo, birkito; to c. by or acquire, obtain samo; to c. down shida, shide, sabka; to c. in shigo; to c. out $f$ ťto and (with pronominal forms ending in na) firfitowa; to c. out from fito; to c. quickly sheko; to c. to gabāto; c. here to me gabātoni; to c. towards iso, jirgo ; to c. up taso; to c. up with tarda, taras $d a$.

comfort, n. 1. (satisfaction) dadi, dadin zuchiya.

2. (consolation) hankuri, hakuri, hankura or hakura, sanyi or sanyin zuchiya.

comfort, tr. v. bada hankuri, sanyaya*, e.g. he comforted them ya bada ma su hankuri. comfortable, to feel, intr. v. jin dadi, jin dadin zuchiya; he felt c. rai ya kwanta. comforted, to be, (feel consoled) jin sanyi, I am c. zuchiyata tana jin dadi.

coming, participial n. zuwa, zowwa, zakuwa; c. back komowa; c. here tafowa; they are c. here suna tafowa. command, n. (order) hakumchi, hukumchi, abin hakumta, abin hakumchi, kaliye, umarni.

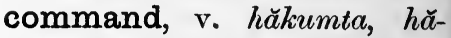
kumche, yin umarni, umarche.

commander, n. (leader, chief) $b a b a$, e.g. tell me the name of their c. ka fadi ma ni sunar babansu.

commandment, n., see command.

commence, v., see begin. commend, see approve of. commission, 1. a c. to purchase saftu, sabtu, sautu, saḳo, dolashi.

2. broker's c., see brokerage.

3. (order) $i z n i$.

commit, v. 1. (to do, to perpetrate) $y i$, he committed theft ya yi sata; one who commits adultery mai-yin zina.

common, adj. 1. (shared in 
by all) na duka, e.g. their common good fortune arziki na su duka.

2. (defiled) haram.

companion, n. kama, pl. kamannu, aboki, dan-uwa*; a c. of the same age tsara; a play c. taubashi, abokin wasa.

companionship, n. tsaranche, gřfi (S.), abuta.

company, n. taro or taru, pl. tarori, jama' $a$; in c. (together) tare; in c. with tare da.

compare, v. 1. gen. misalta, kwatanta.

2. to c. by measuring gualgwada or gwargwada, gwargwado.

compass, iron, n. bukari*. compass (mariner's), for points of see kusuruwa.

compassion, n. tausai or tausayi, jäje, jaijaito*,jinḳai, sauna; to feel c. jin (or yin) tausayi.

compassionate, the, (of God) errahimi*.

compel, v. yin tilas, sa tilas, tilasa, tilas da, dolata, tanlawasa, yin wofi, e.g. you c. me kana yin tilas or kana sa ni tilas, I was compelled to work an sa ni tilas aiki, I compelled the fellow na tilasa mutum, I was compelled an tilas $d a n i$, if he refuses c. him idan ya ki a sa shi tilas; see compulsion, force.

compensate, to ramka.

compensation, ramko, rāmu.

$u a$.

competition, takara.

complain, v. kururuta, kai

kāara.

complainant, mai-kawon kāara, makari.

complaint, n. 1. (loud expression of grief, pain, etc.) kururuwa.

2. (sickness) chiwo, chiwuta or chuta.

3. (a grievance, a cause of c.) Kactra; and so

4. (accusation, a legal term) kīra, sara*, abin sara. complaisance, bajinta; to comply with yin bajinta. complement, n. chı̌ko, abin chŭkauce, yayalwachi*, kishiya*. complete, adj. 1. chikakke, fem. chikakka, plur. chikakku, făfafăta.

2. (of number) ba gaira, e.g. a c. hundred dari ba gaira, lit. a hundred without deduction.

complete, tr. v. găma, hăda*, ida, kârasa; (to bring to an end) kare.

complete, to be, intr. chřka; cf. seq. completed, to be, chika, ḳare; 
often used at end of compositions, stories, etc., e.g. the song is c. waḳa ta cȟ̌ka. completely, atattare, kap. completion, n. chrkau:a; note of c. placed at end of composition iyaka.

compose, tr. v. 1. (of an author) wallafa, yi.

2. (to settle or decide a dispute) sada, raba. comprehend, v. (to understand) yin fahimta, $j i$. compress, tr. v: matse, matsi, mache, dankara*.

compressed, to be, intr. and

pass. matsu. compulsion, abin tilas; under

c. tilas, da tilas; it was a case of c. wofi ya shiga. compute, v., see calculate. comrade, n. kama*, pl. kamannu*, aboki, pl. abokai, abokin uasa.

conceal, tr. v. rufe, rufi or rife*; boye, boyi, intens. boḅboye, jiche (S.), kr̆fa (K.), sulla; kawaichi, e.g. a crime; to c. oneself, to hide boya or boye, also with kai, e.g. he concealed himself under the leaves ya boye kansa dăga kalkashin sansami; to c. oneself (of lying in wait) fake. concealed, particip. rufaffe, fem. rufaffa, pl. rufaffi ; boyayye, fem. boyayya, pl. boyayyu.

concealment, n. boya, boye$w a$; c. of defects in goods offered for sale tadilisi; place of c. maboya, wurin boyewa; see ambush.

concede, tr. v. 1. (to agree to) yarda.

2. (to yield up) bari, bar. conceit, fädin kai, hini (S.), homa (K.), tashin kai, fariya; see pride.

conceive, tr. v. 1. (of thought) tammaha, tamaha.

2. (of the female sex) haifu, samu chiki.

concern, n., see affair and business.

concerned about, be, v. kŭla constr. with direct acc. or with $d a$ or $g a^{*}$; ruwa used with subst. v., e.g. you are not concerned babu ruwan$k a$.

concerning, prep. brsa ga, with prons. gare; $d a, s a b a d a$, sabad $d a$, sabaddo or sabo $d a^{*}$, gami da, game da. conciliation, säduwa. concoct, to c. a story damre magana.

concord, n. saduwa; see agree.

concubine, n. sadāka, pl. 
sadāku, wahaya (a neglected wife or c.), bor $\alpha^{*}$; kwarkwara, kwarakwara, makubliya, mutumniya*.

condemn, tr. v. $k \bar{a} d a, b \bar{a} d a$ laifi, laifa*, küsanchi. condemnation, n. kayaswa, kyazwa, kaye, alhaki, lalata, the last quite general $=$ perdition.

condition, n. (state) $z \alpha m \alpha, z \alpha$ manchi.

condition, to come into a, or state zama, zam (S.).

condolence, (on any misfortune other than death) jaijaito; c. in bereavement ta'aziya*.

condùct, n. (habit) tsabi'a, dabi'a; letter of safe-c. watikal (or wasikal) lamuni. conduct, tr. v. (to lead, bring) kai.

cone, the form of a c. zallo; c.-shaped da zallo.

coney, (Klip-Das), see cony. confectionery, n. allewa, alewa.

confer, v. 1. (to consult together) yin shawara.

2. (give, bestow) $b a, b a d a$. conference, kuchi, pl. kuchekuche; see talking.

confess, v. yin furuchi, yin furchi, yin huruchi, banya, dauki laifi. confession, n. furuchi, furchi, huruchi.

confidence, n. (reliance, trust) amāna, aminchi, aminchewa, dangana, saduda, shaduda* ; to have c. in dangana, dogare, saduda, e.g. I have c. in... ina dangana da...; we have c. in thee mu dogare $k \alpha$; to betray c. chinye amana, chin amana; to justify c. (to be trustworthy) yin aminchi. confine, n. (boundary) iyaka. confined, adj. (narrow) cf. kumchi; to be, v. (of women) haifu.

confirm, to tabbaclee.

conflagration, n. gobăra, turnuka, e.g. prov. gida biyu maganin gobăra two houses are a provision against a c. conflict, n. fada, fama, yaki. conflict, intr. v. kăra, yin kăro, e.g. this conflicts with that wannan ya yi kăro da wanchan.

confluence, $\mathrm{n}$. of rivers, $m a$ gangami, magăma.

confounded, to be, v. damu. confuse, tr. v. (to confound or perplex) dāme, dāma, rikita, shirbata.

confused, to be, v. damu, sho kai; he was c. ya sha kansa. confusedly, adv. damai, marbik $\alpha^{*}$. 
confusion, n. damasa, marbika*, damuwa, kirmiche (S.), rigima, shirbache, purmutsi (K.).

congeal, intr. v. chı̌baru, e.g. my blood is congealed with the cold jinina ya chibaru sabad da dari, sandare.

congratulate, tr. v. barkata, gaishe, gaida.

congratulation, barka. congregate, intr. v. taru. congregation, n. jama'a. conjecture, to kintata; see suppose.

conjoin, tr. v. gama. conjuring, rikirkida. connections, n. coll. dangi, danga or dagi, pl. dangogi, kabila.

conquer, tr. v. 1. (to acquire by war) chi.

2. (to overcome) $i, i m a$, yin nasara, yin nasarchi, kāda, kāshe.

consciousness, n. tunane (a particip. form), pl. tunannu, is used substantively for thought or consciousness.

consent, n. yarji.

consent, v. yarda, bada yarji, $i z n i, k a r b a$, so, e.g. do you c.? I do kana so? ina so.

consequence, n. 1. (effect), e.g. in c. of this don wannan, domin wannan, don haka, sabad da wannan.

2. (importance), e.g. it is of no c. babu komi.

consider, v. 1. gen. tsokachi and yin tsokachi, tuna and tunane with da.

2. (of a council, deliberation) yin shāwara.

consideration, n. (deliberation) shāwara.

consolation, n. hankuri, hakurchi, hankura, haḳura, hakuri, sanyin zucliya.

console, tr. v. bada hankuri; to be consoled jin sanyi. consort, n. 1., see companion, comrade.

2. (of married people) namiji, miji, fem. mata. conspiracy, to form $a, v$. gama*.

conspire, intr. v. yin baki daya. constancy, nāchi, nachiya. constant, adj. da nāchi. constantly, adv. ko yaushe, kullum*, kul yaushe*, tutul, tutur.

constellation, see star. constrain, tr. v. tilasda (S.), tilasa (K.); see compel, force. construct, tr. v. 1. gen. yi.

2 . spec. of roads gina. consul, n. gunsul*. 
consult,v. 1.intr. (todeliberate) yin shawara.

2. tr. v. yin shawara constr. with $m a, g a, d a$, e.g. I am going to c. you za ni yin (or in yi) shawara da kai, sha. warta, shawarche.

consultation, n. shausara, roshi*.

consume, tr. v. 1. (used of fire) lasa, lashe, kona*, k̦one*.

2. (generally) chi, chi $d a$, chanye, chinye.

contain, tr. v., see hold. contaminate, tr. v. yin kazamta.

contemn, kyale, see despise. contemplate, tr. v., see consider.

contemplation, mädai.

contempt, n. reni; an expression of c. wus, wush; tsaki; see despise.

contemptuous, adj., see proud.

contend, tr. v., see fight, strive.

content, adj. ḳosashe, pl. ḳosassu; to be c. koshi.

content, tr. v. kosada, kosasda. contention, n. (disputing) hayaniya, haniya, haya-haya, muhawara*, musuwa; see strife.

contentment, kwanchiyar hankali. contents, (that which is contained) abin chiki.

contest, n., see contention. continually, adv., see constantly.

continuance, n.tabbata, tabbatawa, dawama, duma, dinga, nächi, nachiya, zama, zamanchi; long c. tsawa, tsawanta. continue, intr. v. dawama, duma, dăda, dadi, tabbata, tabbache, dunga, kāra* ; to c. to exist kashi*, kashe*, kasanchi; phr. we c. giving thanks muna lăda godiya; I c. travelling until evening ina yini tafiya; they continued thus suka kāma haka, he continued crying ya kāara kuka.

continuing, mai-dawama, maitabbatawa.

contract, n. wahabi.

contract, tr. v. 1. (a disease) tarda.

2. to c. the facedamre fuska.

3. intr. v. (to shrivel up) yin yaushi, yin yoshi.

4. (to make an agreement) see agree.

contradiction, yardama. contribution, n. (e.g. of food) tarbache.

contrivance, n. dabāra, dubāra, dibāra, chimi*, wayo, waya, abin uayo. 
contrive, v. wayo, wayau. control, tr. v., see restrain. convalescence, n. rangwame. convalescent, be, intr. v. jin or yin rangwame, yin dama, wartsaka.

convenient, adj. sawaba*, daidai; see fit, suitable. conversation, n. bătu, zanche, pl. zantatuka, zanzanche, fira, hira*, tadi, kŭrga (S.), roka (Z.), tankawa, zantawa; hum of c. dumi*.

converse, intr. v. tanka, tamka, băta, yin bătu, yin zanche, yin magana, yin tadi. conversing, jart. tankava,

zantawa.

converted, be, intr. v. sauya, e.g. he was c. from heathenism to Islam ya sauya da arna musulmi.

convey, tr. v., see carry. convict, n. dan sadaka. convince, tr. v. (satisfy by evidence) hakikanta. convolvulus, a species of awarwaro, fărin gamu, kafiboka, yaryadi, yambururu, duman kada, yako.

convulsions, n. mijiriya, minjiriya, misiriya.

cony, agwăda, rema*. cook, tr. v. dăfa, dăfe; c. without water tuya, soya; cooking dăfuwa; to c. meat with hot stones sulala; a fire for cooking wutar găshi. cook, n. mai-dăfi, mai-dăfuwa, sarikin wuta.

cooked, be nĭna (S.), nŭna (K.) ; c. part. dăfāfe ; c. without water soyayye, fem. soyayya, pl. soyayu; well c. ninanne, pl. ninannu, nunanne, pl. nunannu, tapshi, tafshi, tabshi* ; c. food dăfau.

cooking, găshi, dafuwa ; c. place madăfa, wurin dăfa, wurin dafuwa; c. place on which a pot is set murufu; a c. pan algřdiri, alkǐdiri; a c. pot with holes pierced at the bottom madambachi, madamfachi.

cool, adj. sanya, shanya, da sanyi; c.-headedness sanyin hali.

cool, tr. v. sanya, shanya; intr. v. fuche, huche. cooled, part. sanyayye. coop, n. akurki, pl. akurikai, kurki, akurikin kaza. copaiba, tree maje, kadaura. coping stones, kalankuwa. copper, n. jan karife (lit. red iron), gachi; girdle made of c. tagula*, tugula*.

coppersmith, the c. bird makwabkwafi.

copy, tr. v., see imitate. 
copy, to c. a drawing etc. sifata, sifanta.

coral tree, majiriya.

cord, n. siliya, pl. siliyu or siliyoyi; igiya, pl. igoyi or igiyoyi, yagiya (S.); a c. to tie trousers round the waist kubaka.

coriander seed, ridi, lidi ; oil made from c. s. main ridi; a plant resembling c. yaudo, yodo (S.).

cormorant, madundumi*, kazar ruwa.

corn, n. hatsi, (wheat) alkama ; a grain of c. kwaya; guinea-c. dawa, q.v. tsaba(S.); Egyṕtian c. ruasara (see maize) ; a tuft of c. geza, pl. gezuna ; an ear of c. kube; a pit for storing c. tsunjiya; to rub or grind c.tushe, nika, daka ; reaped c. laid in rows sankache, sangache; a bunch of c. kurăsa (S.); c. stalkskarandafi(S.); awoman who sells c. almuda (S.), maauniya, alkwararo (S.). corn-stalk, tip of sullai, siliya. corner, n. kusuruwa, pl. kusurwoyi, sukuruwa, sukurwa; c. of a fence dungu, lungu. corporal, mai-igiya biu, lit. the owner of two stripes.

corpse, n. gäwa, pl. gawawaki, mushe, matache, fem. matachiya, pl. matattu, mamachi. corpulence, kauri, kabri, kosa. corpulent, da kauri, ginshimi, tunturum; to be c. kabrara; see fat.

correct, tr. v. (punish) foro, horo*, wahalshe.

correct, adj. daidai, dèe $\bar{e}, n a-$ kwarai, fem. ta-kwarai, sărai, sosai, ainin; it is c. ya yi daidai.

correctly, adv. daidai, sosai, kwvarai, sărai; to count c. kilga sărai.

cost, n. (price) kurdi; what does it c.? kurdinsa nawa? its c. kurdinsa, an tayansa, tamaninsa.

costly, adj. da tsada; to be c. yin tsada.

cotton, n. kada; c. before it has been spun abduga, auduga; spun c. abawa; white c. for sewing silili (K.), silale (S.) ; small piece of twisted c. shusiya; seeds of c. plant anguriya; silk c. tree rimi; c. from silk c. tree kaderi; a bow string used in cleaning c. labe (S.); a pin used in pressing c. (so called from a resemblance to the buda snake) dan br̆da; a c. farm garge (S.) ; to press c. seeds out of the pods or to roll c. gurje, gurza; intertwined c. staples hădan zare; to clean 
raw c. shřba; to clean or prepare c. by drawing it out (on the masăḅi) săḅi, yin sutu; a white c. brocade samasadowa; for various sp. of cotton see bakatuka, yatsauri, yatabshi.

cotton-wool, sabi, tafa*. couch, n., of a king or judge, karāga.

cough, n. tari, twari, toari. cough, intr. v. yin tari. council, n. fäda, roshi*, magan-

tawa, magantirwa; to hold a c. yin fadanchi.

councillor, bafäde, pl. fadawa; mafada, pl. mafadawa; mafaje (K.).

counsel, n. dabāra, dubāra, dibāra, wayo.

counsel, tr. v., see advise. count, tr. v. yin ḳidaya, kilga, kirga, yin lisafi.

count, n. kidaya, lisafi. countenance, n. fuska, pl. fuskoki or fuskuna. counterfeiting, (coin) tsirariya.

country, n, kăsa, pl. ḳăsashe, kăsaisai, gari, pl. garuruwa, garigari or garigaru; uninhabited s. jeji.

coupling, of animals or birds barbara; of horses, camels etc. baye.

courage, n. mazakuta, maza- kunta, mazakunchi, tasiri (S.).

courageous, adj., see brave. course, $n$., the c. of the world taki-takin duniya.

court, n., c. of a king $f a \bar{d} d a$, wurin shawara, fage, kindigaye ; c. yard dandali; c. of justice fagachi, fakache* ; to appear in c. hălara or hallara. courtiers, n. fadawa.

courting, n. bazaware*, shiri$y a^{*}$.

cover, n., c. of a book bango, pl. bangaye, banguna, tadarishi; dish c. made of grass faifai, pl. fiyafai or fayafayai; see covering.

cover, tr. v. rufe, rufa, rufi, rife, yāne, yin sutura, suturta, turbude; to c. up a hole done; to c. (i.e. to conceal) jiche (S.), kŭfa (K.) ; to be covered rufu, rurrufu; to c. (used of horses, bulls, etc.) yin baye, hawa.

covered, part. rufaffe, fem. rufaffa, pl. rufaffu.

covering, n., e.g. a blanket bargo, mayafi, sutura, sitira, mayāfi, marufi, pl. marufai; rufa, rurrufe; the c. of a door kyaure; c. of skins tunku; c. for a horse mashimfidi, pl. mashimfida; temporary c. for the night sayi, pl. sayoyi. 
covet, tr. v. shahawa, yin guri, yin kări; the coveted horse dokin kări.

coveting, n. hadama. covetous, adj. da rowa, mairowa, makwadaita, mai-kawazuchi, marowachi, da măda. covetousness, n. rowwa, rowa, kawazuchi, tsumulmula (K.), zowari, zwari, zari, makwadaichi, madda.

cow, n. sāniya, pl. shanu; bushcow or dwarf-buffalo bauna, pl. bakane; a black and white c. nordi; an old c. the mother of the herd sayi (S.); an old lean c. guzuma; c.shed turken shanu; a c. tied up by the feet dunguli; cowhide kilago, kilabo, pl. kilagai. coward, n. matsorata, matsorachi, lalafa*, mairaki.

cowardice, n. matsorachi. cow-bird, or ox-pecker, charki. cowhide, n., see cow. cow-itch (Mucuna pruriensis), karara.

cowry shell, n. ijiya, wuri, pl. kurdi, kudi, kawara or alkawara, yaya; a large c. s. gandi, sarmadawa; a bag containing 20,000 shells kesu, kwaroro, kworōro; a large skin bag for cowries juka; a grass bag for holding cowries kwasabro, kwasauro ; a small c. s. ago; gambling games played with c. s. dăra, chacha, modi; a faked c. s. used by gamblers, made by joining two shells together so that the lips or back are always exposed godogo; a girdle made of c. s. kiribi; a c. s. with a hole in it kuruman wuri; a blocked-up c. s. with hole at back filled up likakken wuri ; to throw c. s. in the game of chacha, săba, $s a \breve{b} i^{*}$.

crab, n. kă̄guwa (K.), ḳwāguıva

(S.), pl. kagunai, kwagunnai. crack, intr. v. tsagu; to c. or open (used of a wall) dāre. cracking, of the skin under the toes, kudumbiya, kumbudeya.

crackling, of fire babaka*. craft, n. wayo.

crafty, adj. da wayo, mai-wayo, mai-sane, shaitan*; to be c. hilata.

crakle, see starling. cram, tr. v. (stuff) dora, d̄ura. cramp, n. mijiriya, mijirya, minjiriya, misiriya. cramped, to become, e.g. with cold săge, gage, kage. crane, crested c. or crownbird, n. goraka, gauraka, garmaka (S.), gamraka. crawcraw, n., see crowcrow. 
crawl, intr. v. rarrafe, rubda (or rufda) cȟki.

crawling, n. jan jiki, rarrafo. crazy, tabaḅbe, see lunatic.

crease, to täkura, takure.

create, tr. v. halitta, talitta*, halichi.

creation, halitta.

creator, n. mahalichi.

creature, n. halitta, dabba, dabbo, pl. dabbuna, dabbobi; creatures talikai*:

credit, n. bashi, pl. basusuka; one who wants to buy on c. mai-bashi; cf. idiom it is to a man's c. ya chřka mutum. creditor, n. mai-bada bashi, mabachi.

creed, n. imanchi.

creep, intr. v. rarrafe, sanda, sanduwa, kurda*; to c. like a cat stealthily bayabaya*.

cress, water c. lafuwa; common or garden c. labsur.

crest, of a bird tukku, tukkuua, tsoro, zanko, tuntu.

cricket, n., large burrowing c. gyare; a small species of c., tsanya.

crier, n. (one who cries aloud or proclaims) babbam bade, pl. bambadawa, dan ma'abba; (one who calls to prayer) mai-kiran salla, ladan.

crime, n. zamba, janaya. crocodile, n. kăda, kădo, pl. kădōdi, kăduna or kadunduna.

crocodile-bird, (black-headed plover)ladinkogi, jakin gulbi. crooked, be fandare*, lankwashe; of a tree to grow c. kantare.

crooked, a karkache. crookedness, karkăta. crop of a bird, n. maroro, malolo, kururu, barōro. cross, (or crossing) n. gilme*, pl. gilmomi* or gilnomi*; a c. gilmen itache*; c. beam on top of doorway $\check{a z a r a . ~}$ cross, tr. v. gilma, ketare, etare, swaba, săba, yin ł̣etara; capable of being crossed ketaruwa; it cannot be crossed $b a$ shi ketaruwa; to make to c. (i.e. to ferry over) ketare $d a(\mathrm{~S}$.$) ,$ ketaras da (K.), ketarshe (before a pron.); to c. intr. ketaras.

crossing, n. ketara, pl. ḳetareketare.

crossing, part. ketarewa.

cross-legged, to sit, intr. v. tamatela, tamataila, gijirta, ginchira (S.).

cross-ways, n. mararraban hanya.

crouch, to lăbe (S.), raḅe (K.), raḅa, rabke, rafake, tākura*. crow intr. v. yin chära, yin 
kakaruko, yin kukaruku; cock-crow chäran zakara.

crow, n. species of, shimkake; white-backed c. hankāka, pl. hankaki or hankaku.

crowbar, dāgi.

crowcrow, n. (disease) kaikai, kazuwa; a herb supposed to cure c. kaskawani.

crowd, n. (of people) gayya, taru, masu-tariya, runduna, purmitsi, kirmitsi (S.).

crowding together, purmutsi. crowing, n. chāra, kakaruko, kakarako, kukaruku, kikirikyi.

crown, to năde*.

cruel, adj. muni, maketachi. cruelly, adv. da mūni.

cruelty, n. Keta, mūni, zafin rai.

crumb, n. burugushe, burbushi, bulbudi, barbadi, gutsura, pl. gutsure, diddiga, marmashi.

crupper, (of a saddle) jabaya, jakūturi.

crush, tr. v. matse, matsa, latse, laze, murjeki, murtsuki, murtsekyi, kumtata*, kuntata*.

crust, a dried c. kamzo, kanzo. cry, n. kuka, pl. koke-koke; kuwa, muriya, pl. muriyoyi, kira, tsawa, tsuwa, sowa; loud c. ufu, ihu, tsuwa tsuwa, kururuwa, rakadi, rakwato (Z.). cry, intr. v. (cry out) yin kuka,

R. H. D. yin kurūruwa, yin tsawa, rubsa (rufsa, rafsa or rapsa), kuka; raise a c. dora kira; c. for joy guda; c. wares for sale talla, pl. tallata; there was a c. of fire ana ta rigimar gobara.

cubit, n. kāmu, sabi, zira'i*. cuckoo, lark-heel c. or crow pheasant ragon maza.

cucumber, African c. kurzunu.

cucurbita, n., see gourd. cud, chewing the c. tüka. cultivate, tr. v. noma, nomi, nome; cultivated land round a town or village karkara, karikara.

cultivator, n. manomi, pl. manoma.

cummerbund, mulufi, malufi. cunning, n., see craft.

cup, n. tāsa, pl. tāsoshi, gora, pl. gorina, kwariya, koḳo; a large c. shintali, sintali or shantali, pl. shintalai.

cup, to yin ma wani kafo.

cupboard, n. loloki*, pl. lolokai*.

cupping, n. yin ḳafo, jiniya. curb, n. müdu.

curdle, to daskăra; to cause

to c. daskăre.

curds, n., of milk guntsari.

cure, tr. v. warkadda; to be 
cured warke; the fool is incurable mahaukachi ba shi warkewa.

cured, part. warkakke, fem. warkakkiya, pl. warkakku. curl, intr. v. (used of a snake) tākura.

curls, a woman's c. dauri, taura. current, (of a stream) igiyar

ruwa.

curse, n. la'ana, wada, wadda. curse, tr. v. u'a mugunta, la'anta, la'ane la'anchi, zage, bāchi, gămi may you be cursed! tir, uss, ush.

cursed, part. la'ane, fem.

la'ana, pl. la'anu.

curtain, n. (made of fibre and

let down in front of a doorway) tsaiwa, bunu, arsabari, zabori, kyaure.

cuscus, n. kusḳus*, kuskus*. cuscus-grass, jema.

cushion, n. laferu, leferu, laheru, pl. laferai; c. placed on a donkey akumari.

custodian, mai-riko.

custom, n. ada, al'āda, ta'ada, tāda (S.), pl. tadodi, sabo*, hanya*, pl. hanyoyi*, hăli, pl. hălaye.

cut, tr. v. yanka, yanke, sare, keta, farke, yin saisaya (or sosaya); c. into small pieces sassabe, yanyana (K.), yanyanka, fäfa, girtsa; c. into strips rede; c. round shankumbu; c. down kade; c. cloth shifta, shifche; c. with a hoe shema; c. down the harvest, $g i r b i$; one who cuts off the hands of thieves birgiji.

cut, part. yankakke, fem. yankakka, pl. yankakku ; sararre, fem. sararriya, pl. sararru. cuticle, fiska, see skin. cutlass, n. takobi, pl. takuba, tama, tagomas, tamogashi, adda.

cutting off of hands (a punishment for thieving), yankan hannu.

cutting-up, yanyane.

cylinder, c. on which thread is wound for use in shuttle kwarkwaro.

cymbal, a kind of kuge.

dagger, n. cheru (S.), kanga*, wuka*.

daily, adv. kowache rana.

dainty, he is $d$. over his food shina da taran (or tadan) abinchi.

dais, tugufa*.

dam, for catching fish labuni. damage, n. barna, taskăro (S.). damage, to barnata.

damp, n.daushi, damshi, laima, rima (S.).

damsel, n. yarinya, buduruwa. 
dance, n. rawa, lela, zariya, dawara; a d. performed by young men bauta, lela; an inspired d. bori.

dance, intr. v. yin rawa, taka rausa, raya, wurra, yin zariya, tsalle, birkida.

dancer, a dan foto.

dancers, e.g. those possessed by

a spirit masu-bori, masu-boli. dancing, tsalle, zariya.

dandruff, n. toto, totau, tautau. danger, n. hatsari (K.), hadari

(S.), abin tsoro; a dangerous place wurin tsoro.

dangle, to wo lilo.

daring, adj., see brave.

dark, adj. da dŭfu; phr. it is d. ya yi dŭfu or rana ta dushe.

darkness, n. dŭfu, dŭfuwa, dushewa; utter d. dǔfu kirin. darn, to yin lalaftu, see seq. darning, lalaftu, lalaptu, lalabtu, laplaptu*.

dart, n. hankaltilo, hargi, margi; a d. used for catching fish hăgu, zăgo.

darter, (the name of a bird, Plotus) kazarruwa, mădundumi.

dash together, tr. v. gwabra, gobure.

date, n. (tree and fruit) dabino ; desert d. aduwa; a bunch of dates zaraba*; dates tied up in a mat lubiya; a species of dark coloured d. zabiya, pl. zabiyoyi.

date, n. (time of an event) yayi, zamani*, lokachi*, wokachi*.

daub, tr. v. yāba, yābe, damfara, shafa*, shafe* . $^{*}$ daubing, yābẹe, pl. yābe $y \bar{a} b \underline{b} e$. daughter, n. diya (S.), pl. yammata (for yan-mata), ya (K.). dawdle, intr. v. yin tsaiko. dawdling, n. fatara, tsaiko. dawn, n. wayewa, assuba, fudowa, fudawa; the first glimmer of light before the d. aljifir, alfijir, jijifi, jijif, $j i b j i b$; let us start before the d. $m u$ yi jijifi.

dawn, intr. v. waye; the day dawns gari ya waye or less commonly Allah ya waye.

day, n. (the time from sunrise to sunset) rana, ran or $r a, \mathrm{pl}$. ranuka, ranukka or ranak$k u$, used as masc. or fem., wuni; a day's work wunin aiki; (twenty-four hours) kwana, pl. kwanaki or kwanukka; to-day yo, yau; to stay at a place for a d. yini; three days ago wanshekaranjiya; the $\mathrm{d}$. before yesterday shekaranjiya; yesterday jiya; the following $\mathrm{d}$. rana mai-zakuwa; to-morrow gobe, kashēgari (Kats.), 
wanshekare (S.) ; the d. after to-morrow $j \bar{\imath} b i$; the $\mathrm{d}$. after the $d$. after to-morrow gata; the d. after gata, i.e. the fifth d. chitta; some $d$. or other ko ba dade; the last $\mathrm{d}$. ranan gobe or ranan kiyama; the $\mathrm{d}$. on which randa. (a shortened form of rana $d a$ ) ; every d. kowache rana; all d. rana duka; the d. on which a child receives its name ran suna. When d. is used with ordinal numbers the singular form is usually employed, thus: three days rana uku or kwana uku ; to do a thing every d. dimanta. The days of the week are: Sun. lahadi or ladi, Mon. litini, Tues. talata, Wed. laraba or larba, Thurs. alhamis, Fri. aljimu'a, jumma'a, jummu'a, aljimma, jimma'a or jimmu'a, Sat. assubat, assabat or assibit.

dazzle, tr. v., to d. the eyes makamche; the lightning has dazzled thine eyes walkiya ta makamche ka.

dead, adj. matache, fem. matachiya, pl. matattu, amache, mamachi, fem. mamachiya; a d. body mushe, gawa, pl. gawawaki; (that which has died of itself) $y u b a$; see die. deaf, adj. kuruma, kurma, pl. kurumai; d. and dumb bebe, pl. bebaye.

deaf, be, intr. v. kuruma

deafness, n. kurumchi, karumta, bebantaka, tosuwa (S.).

dealer, a corn d., fem. maauniya.

dear, adj. (costly) da tsãda; to be d. tsadanta; (beloved) masoyi, fem. masoya, pl. masoyu, lele, abin kamna*; to be d. yin tsāda.

dearness, n. (high price) $t s a \tilde{d} d a$. dearth, n., see want.

death, n. mutuwa, machewa, rasuwa, jinkiri*, mata*, (lit. last sleep) makarin barchi; a natural d. mutuwar Allah; sudden d. saukin mutuwa; the angel of $d$. (lit. he who separates) marabiwa.

death-watch, (insect) gunda, gumda, kichichiya.

debt, n. bashi, pl. basusuka, ramche, ranche; to pay a $\mathrm{d}$. biya bashi; to get into $d$. chi bashi; to recover a $\mathrm{d}$. biyo bashi, bim bashi; surety for payment of a d. lamuni, phr. he is in my debt shina da bashina or ina bin sa bashi.

debtor, n. mai-chin bashi, maikarban bashi, mai-daukan bashi, mabachi, mabarch (K.). 
decapitation, kunḳurus, kurunkus, kurungus, ḳungurus. decay, to ruba, riba. decayed, rubabbe, pl. rubaḅu. deceit, n. munafuchi (S.), manafuchi, munafichi (K.), munafuki, barkwanchi, rikichi, hä̈nchi, wayo, lābo*, rudi*, yaudara, algus, algusu, algushi, rigingini, zankam (K.); (lit. two hearts) zuchiya biyu.

deceitful, adj. marikichi, mairigingini, mai-zalumchi, maialgus, mai-algusu, azzalumi, marude, mai-rude, pl. maruda, mai-yaudara.

deceitfully, adv. da zalumchi; to treat d. yin zalumchi; to act d. rikiche.

deceive, tr. v. ruda, rudi, rude; chuchi, chuche, yaudara, shamata, shamache, zantara, hăge. deceived, be, v. rudu, rude. deceived, part. rudadde, fem. rudadda, pl. rudaddu.

deceiver, n. marude, mai-rude, see deceitful.

decide, tr. v. (of a judge) raba, yanka shari'a, yanka magana. deck, to sitirta, suturta.

declaration, e.g. before a judge, biyayya.

declare, tr. v. hadichi, labarta, habarta, fada; d. openly bayăna, bayĕna, chashe; d. positively furuchi, furchi, hurchi, hurta.

decline, v. (grow less) karkăta, rage; the day declines rana ta tawaya, see decrease; (refuse) ki, kiya.

decorous, adj., see becoming. decrease, n. răguwa.

decrease, tr. v. răgi, răge, tawaya, tauwi; intr. v. ragu, tawaya, tawayo, tauwi, tauye, kasas da.

decree, n. ajali*. deed, n., see act. deep, adj. da zurfi, mai-zurfi; a d. place (usually with water in it) gulbi, pl. gulabe. deer, n., see antelope. defect, n. lăhani, aibi, aibu ; see blemish.

defence, kāriya, datsiya*. defend, tr. v., see guard. defer, tr. v. fāsa.

defiance, tamanya, tamayya (S.).

defile, tr. v. tozarta, kasanta, kazamtad $d a$; see pollute. defraud, tr. and intr. v. chin kura, chin riba, săfa (S.), zantara; one who defrauds maizamba, mai-chin kura; see cheat.

defy, to harzuka ga, hasala ga. degradation, kankanchi. degrade, to maida baya. 
dejected, see disheartened. delay, n. fäshi, yauchi, dadewa, indainda, jinkiri; without d. babu fashi.

delay, intr. v. yin fäshi, yin yauchi, wanzu, dada; to d. to deliver a message $i d a$ labari; he delays to come ya yi nauxa or ya yi yauchin zakuwa; to d., tr. fäsa.

deliberate, intr. v. yin shawara.

deliberately, adv. da gangan. deliberation, n. shāwara, pl. shawarori, shawaruna, shāwarwara; place of d. wurin shāwara.

delicacy, a abin marmari. delight, tr. v., see please. delirious, adj., d. persons masubori, masu-boli, yan-bori. deliver, tr. v. (give over) bada, bashi, yarda; (save) cheto, cheche, tsiras da, tsirad da, tsarda, chira, kwache, kwashe. deliverance, n. cheto, tsiraro, machechiya, tsīra, fansa, pansa, hansa.

delivered, be, v. haifu.

deliverer, n. machechi, pl. macheta.

demon, n. aljan, aljani, fem. aljana, pl. aljannu or aljinnu, jinnu; bori, pl. borurǔka, borurǔwa.

demonstrate, to yin tabbas. demonstration, gaye.

denial, n. (dispute in which something is denied) gardama, musu, jayaiyya. deny, tr. v. musu, hana*, ki. depart, intr. v. füta, răsu, rabu, harā.

departure, n. $f \grave{\imath} t a$.

deposit, n. amāna, karo, lamuni*; to steal a d. chin amāna; those who steal a d. masu-taḅin amāna; a place in which to $\mathrm{d}$. anything maaji. depression, a kwări, kware(S.). deprivation, n., e.g. of goods wofi.

depth, n. zurfi; he got out of his d. ruwa ya sha kansa; it is out of a man's d. here ruwa ya shake mutum a nan. depute, to wăkala.

deputy, māmayi, na'ibi; see regent.

deranged, a person, n. maiwauta, mahaukachi; to act as one d. yin raurawa. deride, tr. v. yin $b a^{\prime} a, b a^{\prime} a$, zunda, yin zunde.

derision, n. ba'a, zunde, zumde. descend, intr. v. shida or shida, shide, shido, jīda, sabka, sapka ; descend! ji do. descendants, zuri'a.

desert, n. (i.e. a solitary place) dăwa, daji, sabra*, saura*, hamāda, jeji. 
desert, (worthiness) chinchinta, chanchanta.

deserter, n. (in war) kazum. designedly, adv. da gangan. desire, n. 1. (wish) so, kamna*, marādi(S.), murādi(K.), fata; eagerd. kwwalama (K.), kagăra, marmari; desires zuchiya*, nafsi*, kodai, kwadai ; evil d. shawa, sha'awa, güri.

2. (the thing wished for) abinso, maradi, muradi, guri, nŭfi, nŭfe; he accomplished his d. ya chika hadama.

desire, tr. v. so, nŭfe, nŭfi, yin ḳagăra, yin fāta; to burn with d. Kona, luna*, kone, kwadaye, lamiranta; intr. v. direct the d. maida kamna.

desist, intr. v. daina, dena, bari, bar.

desolate, to make d. yin kadaita.

desolation, n. kango, pl. kangogi or kanguna; afko, kadaita, risbawa, rizbawa, ruzgawa (S.), rubzawa (K.).

despair, to fida zuchiya.

despicable, adj., see despised. despise, tr. v. rena, kyale, yin tsantsani, tarsa*.

despised, part. renanne, fem. renanna, pl. renannu, ląskastache, pl. kasḳastu.

despising, part. renawa, reni; the $d$. of advice renin wayo. despoil, tr. v. (in war) yin buruntu, chin ganima. destiny, n. ajali, jinkiri, kudira, ḳudura, kadara, răbo*. destitute, one who is, 1. gande, gindau, yyande, fem. gyanduwa, pl. gyandaye, fanko, matsiyachi, pl. matsiyata, mayunwachi*, pl. mayarwata*, komaro, karare; cf. rashi, maras. destroy, tr. v. băata, ḅāche, bachi, bāatas, halăka, afka, făsa, banna, yakuta, chi*. destroyed, be, v. lalache, gurbache, yakuche, yamutse* ; about to be d. mai-afkawa. destroyed, part. bätache, fem. bātachiya, pl. bātattu.

destruction, n. afko, halaka, lalata, ta'adi, ta'ada, bātachi. detain, tr. v. riko, tsaida, tsaishe, tsayas da, tsĕre, hana. detect, tr. v. (e.g. in a fault) ritse, rutse.

detention, rikgo.

deter, tr. v., see prevent.

determined, one who is $d$. mai-daurin anniya.

detour, to make a d. zaga.

devastate, tr. v. yin afko, yin kadaita, waso.

developed, i.e. full-grown gawurtache, fem. gawurtachiya, pl. gawurtatu; kasaitache. deviate, intr. v. (from a straight course) bauda, baude used 
with hanya ; ratsa, yin ratse ; causing to $\mathrm{d}$. baudewa.

deviation, ratse, ratsowa.

device, n. hila, fila.

devil, n. shaitan, shetan, shai-

tani, iblis, ibilis ; see demon.

devoid of, see without.

devour, tr. v. rida, chinye, chanye, chingi, hadiye, rushe (K.).

dew, n. rāla; ; a drop of $d$. ď̀gar rāba.

dialect, yare, halshe*.

diarrhœa, n. gŭdawa, gŭdun: daji, zawo, zawayi; a medicine for $\mathrm{d}$. filasko.

dibble, (hoe) sungumi.

dice, n. kuri'a, karen chacha ; a throw of d. jefan kuri'a; to cast d. yin modi (cowrie shells are generally used instead of $d$. for purposes of gambling).

dictation, writing from $d$. shibta*.

die, intr. v. mache, machi, mutu (this is seldom used except to denote the past tense), răsu; d. a natural death yin mushe.

differ, intr. v. yin dabam, yin daban, yin bambam.

difference, n. dabamchi, bambamchi, bambanta, barambaran; what is the $d$. between this and that? minene bambamchin wannan da wanchan? or ina marabin wannan da wanchan? there is no d. ba su bambanta; differences (points of variance) tsakankani.

different, adj. dabam, daban, dabam dabam; d. from $d a$ bam da, dabam dăga, bambam dăga; a l. sort iri dabam. differentiate, to bambanta, yin dabam.

difficult, adj. da wuya; it is d. to know all things abin duniya da wuyan sani; it is too d. for me ya buwaye ni, ya faskare ni, ya faye ni, na kasa or ya fi karifina.

difficulty, n. wuya; with $\mathrm{d}$. dakyat (S.), dakyal, dakyar (K.).

dig, tr. v. gina, gino, tona*, haka; d. in the ground fuda, turbude, yasa, yashe, to dig a new well gina rigiya; to dig out or clean out an old well yasa rigiya; d. up land karta, kirta; d. with a hoe shera, hira (S.) ; d. holes, e.g. for planting trees bisa, bǔshe.

dignified, adj., a d. person datijo.

dignity, mutumchi.

diligence, n. koḳari, himma, kwazo, anniya. 
diligent, be, intr. v. yin anniya, maida himma, maida kokari; be d.! ku bada kokarinku.

diligent, adj. da ḳwazo, maikwazo.

diligently, adv. da himma, da anniya.

dim, to be, intr. v. dindimi, dundumi; to becomed. dushe or dishe.

diminish, see decrease.

dimness, n. dushewa, dishewa ; d. of sight makamchi, bambarakwai*.

dip, tr. v. tsoma, soma*; d. under water nuta, nutse, nutsa; to $d$. the head in water yin kunduma.

dipping, (e.g. of meat in soup) tsomi.

direct, adj., e.g. a d. path hanya sosai.

direction, sassa, bige, guge, waje.

directly, adv. yanzu, ko yanzu, nan da nan.

dirt, n. guiḅa, gwiba, gwiḅi, dauda, ḳazāmi, ḳazamta, kazanta.

dirty, adj. da dauda, łázami, fem. Kazama; to make $\mathrm{d}$. yin dauda.

disagree, intr. v., see quarrel. disagreement, n. sabani, suabani (S.), see discord. disappear, intr. v. gurbache*, rutsa*.

disappointed, be, intr. v. kalmashe zuchiya.

disapproval, a gesture of d., the hand being extended and all the fingers pointed forwards, ambola, dakuua. disaster, see misfortune.

discern, tr. v. $i^{*}$, gane.

discernment, n. basīra.

discharge, tr. v. 1. (fire off) buga, halbi, harbi.

2. (send away) see dismiss.

disciple, n. almajiri, fem. almajira, pl. almajirai.

discomfort, n. make.

discontent, an exclamation of gasa.

discontented, adj. one who is d. matsiyachi, pl. matsiyata. discord, n. fasadi, fasada, kiyayya, swabani, rikichi*, fusuma, gardama* ; see dispute.

discount, n. jāra; a special d. la'ada; what d. is allowed? ina rangwame?

discourage, tr. v. sake fuska (lit. to change the face). discover, tr. v. łaga , see find. discussion, n. maganta, ma-

gantawa, magantirwa; to hold a d. yin maganta. disdain, tr. v., see despise. 
disease, n. chiwuta, chivo. disgrace, n. walakanchi; see shame.

disgrace, tr. v. falasa, fallasa, palasa, kumyata.

disgust, n. kyama, see dislike. dish, n., a large wooden $d$. akushi, akoshi, pl. akussa, jemo; a flat d. made of plaited grass taitai; d.-cover (made of plaited grass) faifai, pl. fiyafai; the knob which forms the top of a d.-cover tuku, tuntu, tsoro, tukkuwa. dishearten, tr. v. kariya zuchiya; phr. you d. me ka kariya ma ni zuchiya, I am disheartened zuchiyata ta bachi; see discourage.

dishonour, n. ḳankanchi, kumya*.

dishonour, to kaskasta, ḳuskunta.

dislike, n. haushi, ḳiyayya, ḳiуеуa, kyеya, kyama; see hate. dislike, tr. v. ki, kiya, yankan kamna, tsangwama; they $\mathrm{d}$. him suna jin haushinsa. dislocate, to, a bone gule. dismay, n., see fear.

dismount, intr. v. shido, sabka, shida kasa, jūda; see alight. disobedience, n. kinji, kiwuya, shishige, tayazwa.

disobedient, he is d. shi ne mai-kangara. disobey, tr. v. kiji, tayas. disperse, tr. v. kawas $d a$, watsa, wāre, walwache, warwatse; disperse! ku waru. dispersed, wararre. displease, tr. v. bata zuchiya; this displeased him wannan ya bata zuchiyarsa; see distress. disposition, n. (temper) hăli, pl. halaye ; good d. farin jini (lit. white blood); bad $d$. bakin zuchiya (lit. blackness. of heart); lalata, kafirchi, mugun gashi*.

dispute, n. gardama, sabăbi, subabi, binch ̌̌ki, fusuma, swabani, tsalmi, tsarmi.

dispute, intr. v. yin gardama, yin kokanto.

disregard, tr. v. rena, kyale, shāmuke; see despise.

disrespectful, d. language or ' contempt of court' ashar. dissemble, intr. v., see pretend.

dissent, intr. v., express d. by turning the head away kauda kai, girgiza kai.

dissimulation, riya.

dissolute, adj., see profligate. dissolve, 1. tr. v. narke.

2. intr. v. narku. distance, n. nesa, nisu, (aloofness) nesanta; to place at a d. nesanta; to keep a d. from nesanchi, nisanchi; a 
measure of $d$. (as far as the eye can reach) jetaka*; I saw him from a d. na hange shi dăga nesa.

distant, adj. dăga nesa, da nesa, nesa; d. from nesa dăga. distinct, adj., see different. distinguish, to kebe, kebanche, kebanta, rarrabe ; it was impossible to $\mathrm{d}$. between $b a$ a rarrabe.

distorted, amurgude.

distrain, to wāshe.

distress, n. nawăya, wuya, wahala, matsiyachi,matsiyata, tsananta.

distress, tr. v. tsananche, sa wahala, dawainiyasda, dawainiyashe, nawăya; that which causes d. abin da wuya. distressed, be, v. fargaba, firgaba, matsu, masu, jin wahala; I was d. na gamu da nawaya.

distribute, tr. v. răba, răbas da, răbas (without obj.), kawama. district, n. gari*, wuri*, gunduma (S.).

distrust, to farga*, tsangwama. ditch, n. ganwa, wuriya.

dive, intr. v. nutsa (K.), nuto (S.), nutse, nitso, ninḳāya, auka.

divide, tr. v. răba, răbi*, rabas da, rarrabi, rarraba, kăsa; to d. in half bãra. divided, be, intr. v. răbu, waruari, wawari.

divided, part. rababbe, fem. rababba, pl. rababbu ; mararraba.

divination, duba. diving, n. nüta.

division, n. răbo, răbu, pl. raberabe; mararrabi; the dividing point of two roads mararrabin hanya; d. of a town (within the walls) shiya, unguwa, pl. unguwai or unguni*; d., i.e.allotted portion, fasali.

divorce, n. sakewa, sȟ̌ki, yayi*. divorce, tr. v., d. a woman shǐka, saki, kore all followed by mache.

dizziness, jiri.

do, tr. and intr. v. 1. (act) $y i$ aiki.

2. (accomplish) yi, $i$, yiwa, iwa, yiwo, iwo, wa, aiki.

3. (succeed) $y i$.

4. to do a thing once tăba.

5. to labour at aikata; phr. it is done an $y i s h i$, it does (i.e. it is satisfactory) ya $y i$; I never did so ban tăba yin. haka; can it be done? shi yiwu? it cannot be done $b a$ shi yiwuwa; which way did he go? wanne waje ya yi? na $y i$ I did, is often contracted into nai. 
doctor, n. mai-māgani, attabibi*, likita*; a quack $\mathrm{d}$. boka, pl. bokaye.

dog, n. kăre, f. kăriya, pl. karnuka, auzu; house d. kăren ğ̌da; wild hunting d. kyalkechi, karkechi, kyarkyechi, kirikinji, kilikinji; a mad d. mahaukachin kăre.

dollar, n. dăla (usually applied to the Austrian Maria Theresa d.), riyali, liyar, madafa*.

dominion, n., see kingdom. done, part., see do.

donkey, n. jaki, fem. jakanya, pl. jakai, jakkai or jakuna; d.'s pad lāheru, laferu; for names of various species of donkeys, see ass.

door, n. kofa, pl. kofofi, kofuna or kofai; kofal gida, gambu; doorway bākin ḳofa ; a mat made of grass or reeds let down in front of doorway tufaniya, arsabari, askuniya, marufin kofa, tsabore, zabore, bunu, pl. bunai, kyaure, tsaiwa, tsawaya; a d. made of corn stalks kwadabe (S.); d. post kwabrin kofa, kulkin kofa; pole or bar to keep the $d$. shut mataushin kofa, madogara, gagarabado ; doorkeeper sarikin kofa; a d. made of palm planks kyauren kyami.

dot, n. (e.g. the d. placed above or below a letter) güda (S.); the large d. placed below the line to denote the sound e yamalä*, imala*.

doubt, n. zuchiya biyu (lit. two hearts), tambaba, kokanto, tantama, zulumi, zalumi, zato, shakka ; without d. babu wawa, babu shakka, babu shak, babu tambaba; an expression of d. wai.

doubt, intr. v, yin (or $d a$ ) zuchiya biyu, yin tambaba, yin tantama, yin shakka, hasashi, hasashe.

dough, n. gaya.

dove, n. kurchiya, pl. kurāche, kurchiyoyi ; ring d. wala, pl. walu, aguwa; red-eyed $\mathrm{d}$. hasbiya, hazbiya ; bronzewinged d. garda; long-tailed African d. bardo; a rock d. jạba dutsi.

down, adv. a ḳasa, a lạas; to put d. sako.

down, n. (of birds) sabon gashi.

dowry, n. gāra, baiko.

doze, to gyangyadi, yin angaje. drag, tr. v. janye, jaye; see draw.

dragon-fly, masu*. drain, (ditch) wuriya. 
drake, n. zakaran dumya, sa kaza.

draw, tr. v. ja, jajaya, kakkare, karkare; to d. forth or out fisge, fizge, fusge, fishshe, zara, tabe, tabi, sakatta, sakache; tod. towards oneself jawo, zaro; to d. after one jaka; d. a line or a furrow kirta, karta; to d. strokes zāna; to d. a sketch súfata, sifache; to d. out sabule; d. a sword zara, zari; to d. the foot on the ground murjeki, murtsiki; to d. water jan ruwa, gugana, dèbe ruwa, dèbo ruwa, dauka ruwa; to $d$. near düno*; to d. back jayi; to d. out, e.g. from water tsamo. drawer, n. akodi*, sanduki*, sanduki*.

drawing, (sketch) š̆fa. dream, n. mafulki(S.), mafarki (K.).

dream, intr. v. yin mafalki. dregs, n. gwiba, gwibi.

dress, n., gorgeous d. daraja; see clothes.

dress, tr. v. (put on clothes) $s a$; d. leather jemi; d. meat fedla nama.

dressed, part. (prepared) gyartachche, fem. gyartatta, pl. gyartattu.

dresser, n. (of leather) majemi, mai-jima. dried, part. kekasashe, fem. kekasashiya, pl. ḳekasassu, busashe, busheshe, bushebushe, sanyaye, shanyaye, fem. shanyaya, pl. shanyayu ; dried-up tree kalun itache, kwaurin (or kwabrin) itache*.

drill, to d. soldiers birga. drill, of soldiers rawa*. drink, n. abinsha; a d. made of honey, pepper and water betso, baiso*; a d. made with flour, etc. koko; an intoxicating $d$. made from guineacorn giya; drinking-water ruwan-sha.

drink, tr. v. sha, shawo, shanye, shanya, shaya; to d. greedily dirki; to give to d. shadda, shayad da, shayas da; it is undrinkable $b a$ shi shayuwa. drinking, n. sha, pl. shayeshaye.

drippings, e.g. from trees ruwan ganye.

drive, tr. v. (d. away) kōra, kōre, koro, famfare, $i$ ma, iza, ije, yin artai ; d. to a distance nesanta; d. away in disgust kasḳasta, kusḳunta; d. out fishe, fishshe.

driver-ant, n. kwarkwasa, kwalkwasa.

driving, n. (away in war) artai, kōra.

droop, to lankwasa, lankwashe. 
drooping, lanḳwaso.

drop, n. diga, dugo, pl. dugogi, d̄aso, darso, tarfi; a d. of dew dugon raba.

drop, tr. and intr. v. 1. (pour out by drops) tarfi, tarfa, yin darshi; it is dropping yana diga.

2. (let fall) saki, tsaga, kubche.

3. intr. v., see fall.

dropping, n. digo.

dropsy, n. făra.

dross, n. (scum of metals) kashin tama, kwam makera. drought, n. farin yunwa, fari*, firi, furi.

drown, tr. v. gangante*, nitsashe*; intr. v. nitso, sha ruwa; he was drowned ya sha ruwa. drum, n. kĭda, kidi, kalango, kurkutu (S.), kuntukuru* ; a large d. ganga, pl. ganguna, banga, dundufa, gangami, jămi*; a small d. bishi; a d. shaped like an hour-glass held under the arm, covered with skin in front but open behind kotso, koso, jauje.juje; a $d$. made out of a gourd talle; a d. with pointed bottom carried in a royal procession tambari; a stringed d. open at one end kuriya, kwuriya; the sound of a $d$. wasa*, girib; large d. used by a king tajini; see tafashe (S.).

drum, intr. v. yin kidi, yin wargi*, kankada, kr̆da.

drummer, n. makidi; a mounted d. masarchi.

drumming, n. kidi, pl. kidekide ; (accompanied by dancing) kidin dambe, garaya.

drum-stick, makidi, makadi.

drunk, to be yin maye, bugu ; particip. bugage.

drunkard, n. mashayi.

drunkenness, n.hajijiya,maye. dry, adj., see dried.

dry, 1. tr. v. kekashe, kekasa, bushe, sanya, shanya, ḳăfe; put out to d. sanyato, jibe; to $d$. in the sun bări*; to d. meat before a fire lyafa, kyapa.

2. intr. v. shekare; to $\mathrm{d}$. up (used of a well) kafe, (wither or d. up as water) tsotsa*.

dryness, kekăsa.

dry season, n. rani.

duck, n. kazan yariba, agwagwa; small water d. jalili; African tree d. kirinjijiya; comb of a d. dani.

duck, v., to d. the head kauche kai.

dumb, (d. and deaf person) bebe, pl. bebaye. dum-palm, n., see palm. 
dun, to d. a person for debt bi.

dung, n. käshi, taki, artai, najasa, najasu, gaitsi, toroso, taroso, tutu, tsura, tsula (S.) ; d. of cows or camels kandilu; d. hole salga, pl. salgagi, sarga, salanga (Zanf.), bayan gida*, kwarkware; d. hill jujai, jibji, birbizo, bizo (S.). dungeon, n. kurkuku, see prison.

duration, matsayi.

during, prep. chıkin, $a, d a, g a$, muddar ransa d. (or all) his life.

dust, n. ḳura, toka*, pl. tokuna*; d. storm guguwa, holoko, huluku.

dwarf, n. wadā, fem. wadaniya, pl. wadani, kūru.

dwell, intr. v. zamna, zauna.

dweller, n. mai-zamna.

dwelling, n. mazamni, mazauni, wurin zamna, shigifa, pl. shigifu or shigifofi.

dye, n. rina; a black d. kwaloko*; a reddish d. galura; a yellow clay used as a d. for women's faces dāla; a red d. majigi.

dye, tr. v. rini, rina, yin tabsa, tŭra, yin tŭri ; d. pit märina, pl. mărinai, karofi (K.); a place where clothes are beaten when being dyed mabugiya; owner of a d. pit or dyer mărinı, pl. masurini.

dyed, part. rinanne, fem. rinanna, pl. rinannu, tŭrarre, fem. turara, pl. turaru. dyeing, tabsa, tausa, tŭri, turanta, yanayi. dyer, n., see dye. dysentery, n. gudun daji, gudun dawa, zawo, anago, ana gudawa, atuni; medicine for d. domashi.

each, pron. adj. kowanne, fem. kowache; e. of us kowannenmu; e. of them kowannensu.

eager, adj. da kwarăka.

eagerness, n. kwadayi, kodai, kwada*, kwarăka; see desire. eagle, n. jisasa (K.) ; crested e. angulun kwakwa; whitenecked e. gagāfa.

ear, n. kunne, pl. kunnuwa; hollow behind the ear geto, gato; wax in the e. Kwanyan kunne, daudan kunne; to erect the ears kere; to turn back the ears lāfe; e. of corn kube, zangarniya, zangarko ; e. of gero cooked for eating tumu.

early, adv. wŭri, da wŭri, dauri; very e. wǔri wŭri; e. in the morning sassafe, 
fudowa, fudawa, tangarai, assuba; e. or an e. start samako, sammako.

earnest money, n. amāna*, shigam biya.

earth, n. 1. (the world) duniya.

2. (soil) kă̌sa, pl. kă̌sashe, kăsaisai, turḅaya, turḍa (S.); very hard e. tsandauri. earthquakes, raye-rayen duniya.

earth-worm, tana, pl. tanu. earwig, tsatso.

easily, adv. babu wuya, ba $d a$ wuya ba, sannu*, da sauki. east, n. găbas, găbaz* ; one who comes from the e. bagabasi. eastward, adv. gabachi. easy, adj. that is easier ya $f$ sauki; see easily.

eat, tr. v. chi; to e. greedily chanye, chinye, rushe (K.), ginsu, gundura, yin hamfude, hamfudi, gamba, chingi, dagwiya; to snatch in order to e. rida; anything to $\mathrm{e}$. abinchi; plenty to e. zari, zowari, jibgi, lashe; that which is good to e. $t u$ tushi; to give to e. chida, chishe or chiyad da; eating a little at a time chiye-chiye; cf. prov. to eat a little at a time is better than to eat up all at once chiye-chiye ya $f i$ chainyewa; eating in secret kurmusu; one who hides himself in order to e. mai-kurmusu.

eavesdrop, to lăbe. eavesdropping, rafake. ebony-tree, kainya, kaiwa. echo, n. kuruwa, koguwa*, jeji ya amsa.

eclipse, n., e. of the moon husufi (Ar.), kamurwata, dushewa; e. of the sun kusufi. ecstasy, n. hauka, haukachi*. edge, n. laauye, kowi, kawachi*; (of stream) refe, kauyen ruwa; (of a knife) kaifi ; (of a sword) bāki; (of cloth) lafe, laji; madaji*, chinkai*.

edged, adj. (sharp e.) da kaifi. educate, tr. v. yin reno*, foro* education, n. lădabi, karātu*. effective, mai-anfāni.

egg, n. kwai (kwoi), kwan kaza, pl. kwanyaye; e. shell kwasfa, kwasta, pl. kosfofi, kwasfofi ; kambori, bambaroki, bawon liwai; a bad e. dunge; yolk of e.gwabduwa, kwabdua, gwanduwa; a hen laying eggs dakwalwa; to lay eggs kanya kwwai, aje ḳwai, ajiye ḳwai (K.).

egg-plant, gauta, yalo. egret, zarbi, zalbi; the great white e. or heron farin zarbi ; little e. balbela, badbila, bilbila. 
Egypt, n. Masar, Mazar*; the inhabitants of E. masarawa. eight, adj. takwas.

eighteen, adj. goma sha takwas, sha takwas, ishirin biyu babu.

eighth, adj. na-takwas, fem. ta-takwas; one e. sumuni. eighty, adj. tamanin. either, adj. ko; e.... or ko... ko ; walau*.

elaeis guineensis, n. (= oil palm) kwakwa.

elapse, intr. v. (of time) shige; see finish.

elasticity, yauki, yabki.

elbow, n. kusuruwan hannu, sukuruwan hannu, diddigin hannu, gwiwar hannu; from the e. to the shoulder damtse, damchi, pl. damatsa or damutsa.

elder, e. brother wa, pl. yeye; e. sister ya.

eldest, adj. babba*, dari fari. elect, tr. v., see choose.

elephant, n. giwa, pl. giwaye ;

a young e. parma; male e. toron giwa, toro; trunk of e. hannun giwa; tusks of $\mathrm{e}$. (i.e. ivory) haḳorin giwa, haurin giwa.

elephantiasis, n. gugi, makulashe.

eleven, adj. goma sha daya, sha daya.

R. H. D. eleventh, adj. na-goma (fem. ta-goma) sha daya.

else, see other.

emaciated, part. a rame, ramamme; see lean.

emancipate, tr. v. yanchi, bada diyauchi.

embankment, läbuni.

embark, intr. v. hau jirigi.

embarrassment, fulako, see shame.

embezzlement, haïnchi.

embrace, tr. v. runguma, rungüme.

embroider, tr. v. yin sharaba. embroidered, (e.g. trousers)

mai-surfani.

embroidery, n. tindumi, shara-

$b a$; e. on a shirt algaba, aska;

e. on front of a tobe kunkun-

gaba, gudungaba, mumbari. embryo, tāyi (S.).

emerald, n. zumurruz*.

emetic, n. katala.

emir, n. amiru, amiri.

emperor, n. sultan.

emphasize, to karfafa.

employment, safara (S.).

emptiness, n. wofi, yofi (S.).

empty, a place that is e. kango,

pl. kangogi or kangaye. emulation, n. kishi, kishiya,

pl. kishiyoyi, gāsa. enable, tr. v., see help.

encamp, intr. v. shida, shide,

sapka. sabka, sauka. 
encampment, n. sansani, zango, wurin sabka.

enchantment, sihiri; see sorcery.

encircling, n. kewaya, kewayo. enclosure, n. (for cattle, etc.) garke, garge (S.), sayi; see fold.

encompass, tr. v. (e.g. a town in war) rize.

encounter, tr. v. gama da, gamu da, tariye.

end, n. kāare, karko, makari, makare, karshe, makoma; (boundary) iyaka.

end, 1. intr. v. kāre, tsaya, tsayi, mutu*, yamutse; come utterly to an e. karkarare.

2. tr. v. wanya, wanye, wanyi, kāre; (e. conversation) yanke mayana; the affair is ended ya lare.

endeavour, n. kokari. endeavour, intr. v. yin ḳolkari; one who endeavours maikokari.

ending, karewa, karko, tukewa. endurance, tasiri (S.), see courage.

endure, 1. tr. v. jimri, daure.

2. intr. v. (suffer) dauri; (continue) yin karko, dada, dadi.

enduring, part. 1. (lasting) dadewa, matabbăta.

2. (suffering) see patient. enemy, n. abokin gāba, makiyi, pl. makiya, mai-kinji, magabchi.

enfranchise, tr. v., see free. English, adj. wherever the word is known the form Ingliz or Ingilis borrowed from the Arabs of N. Africa is used; an Englishman would be mutum Ingilis.

engrossed, to be e. in anything shagula, natsu.

enjoy, tr. v. sha*, chi*; to e. the shade sha inuwa.

enjoyment, n. murna, abin murna; see joy.

enlarge, tr. v. fadada, yin girma.

enmity, gāba, zaman.

enough, n. da ya isa, buss, kul; to have e. koshi; one who has eaten e. kosashshe, pl. kosas$s u$; it is e. ya isa, ya loshi*. enquire, see inquire.

ensign, n. tuta, pl. tutochi. enslave, tr. v. maida bawa, bautad $d a$; to be enslaved shiga bauta.

ensure, to wajabta, see certain. entangle, to nunade, dăne*, jiche (S.), kžfa (K.), surmuḳa ; to become entangled sarke. enter, tr. v. (go in) shr̆ga; (come in) shr̆go; cause to e. shr̆gas da. entice, tr. v. rude. 
entire, adj., see complete.

entirely, adv. kap; see also faye and $f$.

entrails, yan chřki.

entrance, n. (aperture) lkofa ;

e. room (e.g. to palace) dandali.

entrap, tr. v. yin hako, yin tarko.

entreat, tr. v. biko, roko.

entrenchment, n. kăgara, kăgaruwa, pl. kăgaru, sansani.

entrust, tr. v. bada, yin sabtu, danka.

enumerate, to lisafta, lisalta, lasalta, lisabta, lisanta.

envy, n. keta, kiyaiya, kishi, kishiya, hăsada, haushi.

enwrap, duntsa, duntse.

epilepsy, n. falfada (S.), farfada (K.), farfadiya.

equal, adj. sosai, daidai, tangam, tangas; to make e. daidaita, yi ya; to be e. isa; a thing which is e. to abin gamawa; this is e. to that wannan ya yi ya wanchan. equal, (fellow) tsära, pl.tsarare. equality, sauwi.

equivalent, n. wato*, watau*. erase, tr. v. yin maimai, shäfa, kankara.

erect, tr. v. tashe, tada.

err, intr. v. manta, manche, kuskure, saba. errand, n. sako.

error, n. mantuwa, kure, sabo. eructate, to yünkŭra.

escape, n. place of e. wurin tsira.

escape, intr. v. fichi, furche, tsīra, gudu, kurchi, kurche, kubche, subuche, subiche. escort, n. rakiya(S.), răko (K.), kǔto.

escort, tr. v. yin rakiya, răka, răki, răke, roma*.

espy, to hanga, hangi, hange, hango; I espied him afar na hange shi dăga nesa, he was the first to e. me ya hango ni. establish, to tuturta, kafa. established, part.(tirmly tixed) tabbatachche, fem. tabbatachchiya; kăfaffe, fem. kafaffiya, pl. kăfaffu.

esteem, n. hasafi.

estimate, tr. v. kauwama, kawamata*, kimanta.

estrangement, n. rabuwa. eternal, adj. hal (or har) abada. eunuch, n. $b a b \bar{a}$ or babani, pl. babānni, laihi, marmāta.

euphorbia, n. kumkumiya, fidda-sartse, kyarana, tinya. European, n. ba-Ture, p]. Turawa*.

evade, to zūke.

even, adj. 1. (smooth) da samtsi.

2. ef. e. or odd chı̌ka ko mara. 
even, adv. ko; e. now ko yanzu. evening, n. mareche, maraiche; yamma; late e. almauru, almuru, magarub, magariba, mangariba, lisha, cf. under rana; in the e. $d a$ mareche, da yamma; phr. I continue travelling till e. ina yini tafiya, it is e. mareche ya $y i$; to depart in the e. maraita. eventually, adv. yauyau, yoyo.

ever, adv. 1. (at any time) $d a$ dai, taba, e.g. have you ever seen him? ka tăba ganinsa? have you ever been to Sokoto? ka tăba je Sakwato?

2. (for ever) tutul, tutur, tutu, tutuk, tutut, hal (or har) abad̄̄.

everlasting, adj. matuturchi, madawami*, matabbatawa*. every, adj. duka, duk,kullum*; everyone kowa, kowanne, fem. kowache, pl. kowădanne, see Gr. p. 18 ; everything duka komi, dukachin komi, komi; e. day kowache rana; e. morning kullum safe; e. night kullum dare.

everywhere, koïna.

evil, n. abin mugu, bannai, mugunta, shara, shariri, gaya*, swaḅo, zunufi; zun$u b i$ *, e. desire sha'awa; e. disposition lalata, mugunta, kafarchi, kafirchi; e. thought băkar zuchiya; e. spirit ibilis ; e. speaking annamimi; e. principle existing in the world duniya* ; e. doer maiswabo ; to e. intreat llanķanta.

evil, adj. mugu, fem. mugunya,

pl. miyagu, mummuna* ; see bad.

ewe, n. tumkiya, pl. tumāki. exact, adj. sarai.

exactly, $r a b, r a p$; it fits e. ya kama rab.

exactly, adv. tangas.

exaggerate, gina waiwai, yalwata labari.

exalt, tr. v. daukaka, daukake, maida girma.

exalted, part. (epithet applied to God) ta'ala, madaukaka.

examine, tr. v. dandana*, dandani* ; see look at.

example, n. koyi, nüni, koko$y a^{*}$; his e. kokoyansa.

exceed, tr. v. buwaya, buwaye, $f i, z o b a$ (S.) ; dada* ; e. in strength gargara, gagara.

exceed, to e. in (have much of) yawaita.

exceedingly, ainin.

excel, intr. v. faye, d̆ăa (S.), yin fifiko, gota, girme; to e. in size gofa; who excelled the other? wanerie ya $f$ wani? 
excellence, n. fiyayya, fiyayye, fiko, kayatazwa, kwwari. except, adv. sai, sai dai, sai ko. excess, n. abinda ya faye, yawa.

exchange, tr. v. sake, yin musaya, furfura, furfuri.

exchange, in exchange for a bākin, maimakin, săbad $d a$. exchange, to (barter) furfuri. excitement, n. karăya.

exclamation, n. (expressing astonishment or incredulity) hŭba, hăba, kaiya, ḳāsa ; (expressing doubt or grief) wai; words used as an e. maganar zuchiya; e. of annoyance kash, gasa ; e. denoting exultation woho, oho; (expressing pity or disgust) $a s h a, h a s h a$; (e. to attract attention) $i h u$, $u h u$, ufu, yeho; e. of welcome măraba; see also oho; an e. used in driving sheep $u s, a s$; e. of despair wayuniya* ; e. of pleasure yauro; see indeed. excrescence, e.g. a swelling gŭda (S.).

excuse, n. huja, yarji*, hamzari, hanzari; a poor e. gajeren hamzari; he made e. ya yi sāne.

excuse, tr. v. gafara, yin gafarta; phr. e. me ba ni yarji, gafara.

executioner, n. hauni (K.). exercise, n. to take e. (by walking) yawo, wasa jiki; (by riding) kilisa.

exhausted, part. sumamme; e. land semu* (S.).

exhibit, tr. v. nuna, nuni, gwada, goda.

exhort, tr. v. gargada, galgada, wajabta.

exhortation, gargadi, galgadi. exist, intr. v. kashi, kashe, wanzu; see be.

expand, 1. tr. v. shimfida, shinfida.

2. intr. v. yalwata, yin auki, yin abki, habama*. expansion, auki.

expect, tr. v. (to await with expectation) jira ; (to anticipate) tamaha, tammaha, yin tamaha, yin zache.

expectation, halamu, zache, $z a ̆ t o$; unfulfilled expectations tsamanin warabŭka.

expectorate, intr. v. tofi, fesa, furja.

expedition, military debe, sa'ati.

expel, tr. v. kora, kore.

expense, n., see cost.

expensive, adj. da tsada; phr. it is too e. ya fi tsada or ya faye tsada; to be e. yin tsada.

experienced, part. gwani, goni, pl. gwanaye. 
expert, adj., see prec.

explain, tr. v. waye, nuna, nuni, hadichi, yin fassara, fasalta, habarta*; phr. e. it to me ka găya ma ni, ambato ni. explanation, n. wayewa, nunawa, fassara, fassaranta, azanchi.

extend, tr. and intr. v. yalwata, see expand.

extended, be, intr. v. miku. extensive, tafkeke*, tabkeke*. extent, n. matsawa, matuka; see limit.

extinguish, tr. v. bishe, biche, kufuli*.

extract, tr. v. jawo, fisge, fizge, fusge, fishe, fishshe, fushe; to e. juice etc. tatsa.

exult, intr. v. yin rāha. exulting, n. rāha.

- eye, n. ido, pl.idanu, idanduna, idanuwa; eye-ball kwayar ido; e. socket gurbin ido, gulbin ido; pupil of e. ijiyar ido, matsokachin ido; eyebrow gira, pl. girare; e.-lashes kain ijiya; ridge over the e. kashin ido; e.-glass madubin ido; mucus from the e. kwamtsa, kwamtso; diseases of the e. hakiya, hakanya, chizara, shawora; cataract in thee. tsauriya or tsawariya; medicine for the eyes korino, fidili, giwa-kamba; a man with deep-set eyes mai-kwarmin ido*; a man with only one e. mai-ijiya na gřda, mai-kishin ido; a blemish in the e. lahani; watery e. (i.e. desire) ruwan ido ; evil e. kandu or kandun ido; one with evil e. maye, fem. mayya; to put the evil e. on anyone jifa wari da ido; e. witness shaidan ido; to have dim eyes dindimi, dundumi; to look with eyes nearly shut yin kankanin ido.

eye-brow, gira, pl. girori, girai or girgira.

fable, n. tatsuniya, pl. tatsuniyoyi, misali, almara*, fira*, gātana.

face, n. fuska, pl. fuskoki and fuskuna, huska*; to f. towards the speaker gabāto; to $f$. in a given direction fuskanta ; f. to f. fuska biyu; to fall on the f. facli jiche; he looks one straight in the f. idonsa kirikiri ne. fade, intr. v. fafe, fofe, yaushi, yin yaushi, (used of cloth) kwaki.

fading, adj. kwaki.

fading away, part. kwāke.

fail, intr. v. (decay) rasu; (f. to keep a promise) kuskure, 
kurkura ; (fall short of) kāsa, găza ; f. to get tābe, tafe; f. to understand rudi; cf. he failed me in nothing $b a$ ya kāsa ma ni komi ba.

faint, adj. sumamme.

faint, intr. v. yin suma, jin suma, suma, gaji.

faintness, n. suma, jiri, kumallo, falfada (S.), farfada (K.).

fair, adj. kyau, da kyau, maikyau.

faith, n. aiman, imani, aminchi*; the faith of Islam musulumchi; see believe.

faithful, adj. yardaji, salihi*, pl. salihai*, mummuni, fem. mummuna; the f. amintattu. faithfulness, n. aminchi.

fakir, wali (Ar.), waliyi, pl. waliyai.

falcon, n. shafo, shaho.

fall, n. fäduwa, saraya.

fall, intr. v. $f \bar{a} d i, f \bar{a} d a, y i n$ saraya, kucha*, sako; f. down before anyone rusuna, runsuna*; f. in (used of a well) gabche, gache, gwabche, abka, burme; make to f. goche $m a$; f. upon falma, farma, parma, haye; f. in with tsayi, tsaya; to let a thing f. $f \bar{a} d a d a$; to $\mathbf{f}$. in price, yin goino*; to f. out with sha bambam. falling, part. fāduzva; f. into ruin rushewa; sound of $f$. glass ḳilin ḳilin, kirin ḳirin; $\mathrm{f}$. in of a well burma.

false, adj. mara-gaskiya; to spread f. news kwarmato, chinewa, tsinewa; it is f. kariya $n e$; f. witness shaidan zur.

falsehood, n. kariya, ḳariya'chi, zur.

falsely, adv., to swear f. yin kafara.

falsify, to kirfa.

fame, n. yăbo.

familiarity, sabo.

family, n., members of f. iyali, uma*, dangi.

famine, n. yunwa, farin yun$w a$.

fan, n. fifiche, mafuchi, pl. mafilfichi (S.), mafifichi, mafirfichi (K.); (made of woven grass) faifai, pl. fayafai; f. made of ostrich feathers figina, figini; (made of palm leaves) giginya, pl. gigangani, giginyoyi or giginai; (for winnowing) $b a$ kache, matankadi, rereya, rairaiya.

fan, tr. v. fifita, fēta, bakache ; one who fans mai-bakache, mafechi.

fancy (supposition) usuwasi.

fanning, fifita, fitara.

far, adj. da nesa. 
far, adv. nesa; as far as har, hal, har ga, tun, tun da; to place f. off nesanta.

farewell, n., to bid f. yin ban kwana, yin salama; an expression of f. sai wata rana. farm, n. gona, pl. gonaki or gonakai, karkara, pl. karkarai; farming aikin gona; owner or cultivator of a $f$. mai-gona; a farm lent by a master to a slave gayauna* ; a f. labourer who works for wages kwadigo, dan kwadigo; f. work noma; farming in one place and living in another nomijüde.

fashion, n. (mode, custom) hăli, pl. hălaye, yayi; rings were the f. ana yayin mundaye.

fast, n. ăzumi; the f. month labaran.

fast, intr. v. yin ăzumi. fasten, tr. v. (e.g. with nails) kăfa ; (tie) damre, balla. fastened, part. kafaffe, (closed) girkakke, fem. girkakkiya, pl. girkakku.

fastening (or loop), maballi. fat, n. ǩ̌ba, pl. Kibobi, kitse, kiche (S.), maski (S.), kauri, $k a b r i$, gwabi; f. of meat mai. fat, adj. da ḳ̌̆ba, da gwaḅi, mai-gwaḅi, da kauri, da kabri, ginshimi, da taiḅa, tunturum; one who is $\mathbf{f}$. mai-tumbi,mai-gato, mai-jiki, kutumba,gandi,fem.gandiya; to grow f. yin lăba, taiba a, yin tiriniya; to fatten kibata. fate, n. jinkiri; see destiny. father, n. uba, pl. ubanne, ubannai or ubanni, bābă ; father-in-law suruki.

fathom, găba.

fatigue, n. găjiya, găjewa, gajiyawa, gayara.

fatigued, to be f. gaji, yin gajiya.

fatness, n. taiba, tiriniya.

fault, n. 1. (defect) aibi, aibu, pl. aibobi.

2. (offence) laifi ; f. finding bimbini.

favour, n. alhèri, tagomashi. favourite, dan tatangi ; f. wife mowa.

fear, n. tsoro, tunzura, dimauta (S.), tunzuruwa*, razăna, gizo*, falgaba, fargaba, raki; to cause f. bada tsoro, tsoratad da, tsorata.

fear, tr. and intr. v. jin tsoro, razăna, răzani, tsantsanta.

feast, n. buki, biki, idi, laiya, adaras*; to make a f. yin buki.

feasting, part. (esp. used of marriage f.) wasan buki. feather, n. fikafike, fiffike, fikafiki, pl. fikafikai; fukafuki, 
pl. fukafukai, gashi* ; a wing f. lili.

fee, $n$. (paid by recipient of a royal present) tukuichi,takwichi; market f. or the commission paid to a broker in the market lada; a court $f$. ijara, ujera*.

feeble, adj. kumäma, maraskarifi.

feebleness, n. kumamanchi.

feed, 1. tr. v. (to supply with food) chida, chishe, kiwata, chisad da, chiyar da.

2. intr. v. (to eat) kiwo.

feeding, chima.

feel, tr. v. to perceive by touching $\ddot{j}$, tabar; to feel or grope for lalabe, lalaba; to be affected $j i$; to $f$. about whilst searching fäfake, mămare ; to f. anything in order to test its weight jinjini; to f. afraid jin tsoro.

feint, n. (pretended attack) zanzoma.

fell, tr. v. (to cut down) sare.

fellow, n. (partner, match) kama, pl. kamannu; tsara, pl. tsarare; a f. traveller maraki, marako.

female, n. (of human beings and animals) mache, pl. māta; phr. male and f. wane da wanche.

female, adj. ta-mata, ta-mache. fence, n. damfämi, darni; a f. round garden danga, $\mathrm{pl}$. dangogi; a f. made of stalks or thorns to keep in sheep, etc. shinge, shingi, shimgi, shimge, pl. shimgaye.

fencing, n. (a game) sharo, takai.

fern, hare's spear f. mashin zomo; elk's horn f. dafaddu. ferry, to f. across yin fito, ketarad da (S.), ketaras da (K.), ketarshe (before a pron.). ferryman, n. sarikin ruwa, maketari, mai-fĭto.

festival, n. sallata.

fetch, tr. v. kawo, zo da; see bring.

fetish, a f. spot matsafa.

fetters, n. malwa, mulwa (S.), pl. mulwoyi (S.); mări, pl. maruruwa, maluluwa, gigar, sarḳa, dilka.

feud, a blood-feud tarna.

fever, n. masassara, zazzaḅi, jante, janti, gyante, mura; I have fever jikina ya yi dumi; a f. which occurs when the guinea-corn is ripe chiwo na sabon dawa.

fever, to have f. yin zazzabi. few, adj. kădan, kankane, fem. kankanuwa, pl. k̦anḳana, Kanana, tsaraurau, kīma. fez, n. füla, wula*, fulan dara, fulad dara, tagiya. 
fibre, n., f. of palm tree $k a b a$; a f. used for making rope tsaiwa.

field, n. a cultivated f. fili, pl. filaye; faḳo, pl. fagaigai; gona, pl. gonaki or gonakai; a barren f. sabra, saura (Z.); a very large f. karkara, pl. karkarori.

field-mouse, gyabji, gyauji. fierce, adj., to be f. haukache. fiercely, adv. da kangara, zafi. fifteen, adj. goma sha biyar (or biyal) sha biyar.

fifteenth, adj. na-goma (fem. ta-goma), sha biyar. fifth, adj. na-biyar, fem. tabiyar; one f. humusi. fifty, adj. hamsin.

fig, n., f.-tree itachen baure; f. fruit baure; for other species of ficus see chediya, gamji(S.),ganji(K.),durumi, kawuri or kawari shirinya, uwar yara, wa, rubiya.

fight, n. fäda, fama, kokuwa, kokowa, yaki, jayaya or jayaiya, sabuwa.

fight, intr. v. făda, yin făda, yin fama, yin kokowa, yin jayaya.

file, n. zarto, darto*, magagari*.

file, tr. v. gurjago, gurzago; to f. a sword yin akaras. fill, tr. v. chřka, yin fal; to f. full chǐkakka; to f. up a hole turbude; phr. fill them up kawo chikonsu.

filled, part. chřkakke, fem. chı̌kakkiya, pl. chı̌kakku ; to be f. chǐka.

filling, part. chı̌kawa.

filter, n. (usually in form of small basket through which water is strained out) marari, abin rīga, maregi.

filter, tr. v. rare, twatsa, tatsa, tache, rēge (S.); one who filters mai-rarewa.

filtering, rĩga, tachewa, tata. filth, n. dauda.

filthiness, janaba.

filthy, adj. da dauda; to be f. yin najasa.

fin, (of a fish) kăafa.

finch, a species of, with greyblue plumage and red tail sisita; black-headed weaver f. shaida; fire f. baiwar Allah; widow f. or Whydah bird, or widow weaver $z a$ laidu, zulaidu.

find, n., e.g. treasure-trove galala.

find, tr. v. samu, same, sami, sama; try to f. tuske, tuski; to f. out (discover) leaga; to f. and bring samo.

fine, n. tara, taro.

fine, 1. adj. (thin, delicate) laushi, da taushi. 
2. (beautiful) $d a$ kyau; very f. kălo kălo; very f. thread arafia.

fineness, arafichi, rabshi, roshi, taushi.

finger, n. yātsa, pl. yātsosi, yātsu; the little f. autan yatsa, dan kure; middle f. yatsan tsaka; f.-nail farchi, farche, kambari, kumba, pl. kumbuna or kumbai, danuba. finish, n., see end.

finish, v. kāare, karki, wanya, wanyi, wanye, găma, gŭma, tuka, tuke, $\bar{\imath} d a$, shide.

finished, part. kafaffe, fem. kafaffiya or kafaffa, pl. kafaffu; phr. it is f. ya kare, ya tsaya tammat* ; he f. speaking ya yi magana ya kare; the month is f. wata ya mutu.

fire, n. wuta, pl. wutaitai, wutache; fire-place murufu, murfu; a f. which has burnt downrufushi,rubshi,rabchi*; restoration of a dying $f$. gwamin wuta; to light a $\mathrm{f}$. fura wuta, hasa wuta; to catch f. chin wuta; make a large f. $g \breve{a s} a$; to strike f. with a flint kyastu wuta; to miss f. (of a gun) fasa, yin kariya; to f. a gun halbi (or buga) bindiga; a f.-swallower kumuria.

fire-brand, bakin wuta. fire-finch, baiwar Allah.

fire-fly, n. dimin dawa, makesuwa, mai-kesuwa, mai-kyasuwa.

firewood, n. itachen wuta, kirari, kirare.

fireworks, n. wasan wuta; (display of) wowo.

firmament, n. hawa*, sama*. first, adj. na-fari, fem. ta-fari. first, adv. na-farko, da farko, da färi, tukun, tukuna; to be f. to do anything wada, I am the f. to come na wada. zuwa.

fish, n. kifi, pl. kifaye, kifofi; mud- or lung-f. gaiwa; electric cat-f. minjiriya, mijiriya, misiriya ; large f. from which oil is obtained gini, zau ; a kind of dog-f. larāya; a shell-f. lamba*, pl. laumbuna*; a flat f. with reddish snout liuma; cat-iish ragon ruwa, tarwada, mari, kurungu, gwando (S.), gartsa (K.), kulme; sting-ray $\mathrm{ku}$ nämar ruwa; a f. with a belly like a frog talibamban; thread-fin abokin taru, Nile perch giwar ruwa; cichlid perch karpasa, karfasa, karpashe, gargaza ; tiger-f. tsage, kawara, shambana; mormyr lulu, dan sariki; a f. like a salmon faliya, fariya; 
for other species of $f$. see under gargaza, baramchi, bana, bod̄ami, dummi, hariya, ishi, kukku, milgi, rajiya, silla, sololuwa, yauni; f. bones kayan kifi; a hand-net for catching f. koma, homa, foma; a spear for catching f. hagu; a f. trap murumuru, sankuja (K.), sankiya ; wicker-work snares for catching f. tsatsara, sasasara; a cord or stalk on which f. are carried lesshi. fish, tr. v. sunta, sunche, intr. yin fatsa, kama kī $f$; f. with small hand-net $s u$.

fisherman, n. masunta, pl. masu-su, dan fatsa, masunchi.

fishing, sunta; a place for $\mathrm{f}$. masunta.

fishing-basket, suru.

fishing-hook, kugiya, pl. ķugiyoyi, fatsa, lugiyar fatsa.

fishing-line, igiyar fatsa, mammari, marimari, murumuru, murimuri.

fishing-rod, itachen fatsa. fissure, e.g. in stick or rock gebe.

fist, n., to close the f. tunkushe ; to strike with the f. dankwasa, dankwashe, naushe; see box.

fit, n. (fainting f.) gamata, falfada. fit, to, cf. it fits exactly $y a$ kama rab (or rap); that which is fitting sawaba.

fit, adj. da ya kamata, sawabe*, sawaba*.

fitting, be, intr. v. kamata, gamshe, gama*.

five, adj. biyar (K.), biyal (Kats.), biyat (S.) ; f. thousand hamsa*, q.v.

fix, to f. a tax yanka gandu; to f. a price yanka kurdi; see fasten.

fixed, to be f., e.g. in a tree rungǔma.

flag, n. tuta, pl. tutochi.

flame, n. halshen wuta (lit. tongue of fire), balbalniya. flap, v., to f. the wings fuffuka, fiffika.

flapping, e.g. of wings fuffuka, pupuka.

flat, a f. place without trees kanga; he fell f. ya fadi $\therefore$ kita.

flatten, tr. v. nāna.

flattened, part. nananne, nanake.

flattery, n. kirari, lallashi, ban magana, godo, yin godo, ma-abanchi.

flavour, n. gardi, zaki, zazza$k a^{*}$; the nut has a good $\mathrm{f}$. gyada tana da gardi.

flax, $n$. string made of $f$. kirtani. 
flay, tr. v. feda, fede, fida, fide, fige*, figi* saba, sabe.

flaying, rī da.

flea, n. tunkwiyo, tunkwiya, chichifi; pite pite f. tsando, kйma.

flee, intr. v. gudu, guje, furche, tsire,yin chŭri, füffika, füffuka, tunzura, sukuwa, suka, sukwani, ruga, rugo; a place to which to f. wurin gudu; to make to f. rauga; see drive away.

flesh, n. nama, pl. namomi, namuna; uncooked f. nama danye; (bush-meat) naman daji; cooked f. dāfau.

flight, n. gudu, guduwa, cȟ̌ri, fartat*; to put tof. bada janfi*. flint, n. kyastu, ketu, kyetu; f. in a f. lock gun damishi, kankara, dutsim bindiga; to strike fire with a f. kyastu wuta; f. and steel for striking a light masabi, masebi.

float, used by fishermen, made of twigs karu.

flock, n. garke, garge (S.), pl. garkuna.

flog, tr. v. fyada, fyade, doke, buga, yin kurfu, yin bǔlāla, fiade.

flogging, n. kurafu, kurfu, karfu*, fȳạ di, kāshi.

flood, n. rigyawa, chikōwa, chichikōwa, tabki, malala*. floor, n. 1. (for threshing) masussuka.

2. to stamp down a $\mathrm{f}$. dăbe.

florin, fataka*, pataka*.

flour, n. gāri; the coarse f. which is separated from the finer f. of wheat tsăki; f. mixed with water taliya*.

flourish, intr. v. yalwata.

flow, intr. v. f. quickly tumbuclu; to f. together saje.

flower, n. füre, pl. furanyi, furaye; a plant with a thistle-like flower which grows in cultivated fields (Vernonia perottetii) burzu. flute, n. algaita, algaitu, sare$w a$, sheshe (K.) ; a reed from which flutes are made kusumburuwa.

fly, n. (common house f.) $k u d a$, kuje, pl. kudaje, kudaidai ; horse f. gwarje, bōbuwa, barbaje, damisan dawaki; a piece of leather placed on horses' eyes to keep off flies furtali, futali; fire-fly dimin dawa; sand-f. fiffilwa, filfilwa, kyafirfita, kiyashi, kudan garke; a large horse $\mathrm{f}$. makafon keda; dragon-f. masu; a large biting $\mathbf{f}$. tsanji.

fly, intr. v. (of a bird) shawage, jawagi*. 
foal, n. dukushi, fem. dukusa, pl. dukusai, dan dukushi. foam, n. kunfa, kumfa, kumpa. foam, to yin kunfa. fodder, kansuwa, lyasuva ; see grass.

foetus, of animals tāyi.

fog, n. hăzo, ḳāsashi.

foggy, adj. da hazo.

fold, n. (for sheep, etc.) garke, garge (S.), pl. garkuna, turke, pl. turāku (K.), turuka (S.), rugga; cutting folds of cloth kirfawa.

fold, tr. v. (cloth, etc.) nimka, linke, yāfa, yāfo, ḳunsa, kunshe, lauya, tākura.

folding, (the arms) buku;

f. cloth rŭbiye.

foliage, n. ganyen itache.

follow, tr. v. $b i$; f. a path $b i$ hanya; to $\mathrm{f}$. in the direction of the speaker biyo; following (esp. used of loyalty to a patron) biyeya, biyawa.

followers, n. masu-bi.

folly, n., see foolishness.

fond, adj. to bef. of yin marmari. fondling, n. act of f. lalaba, taushe.

food, n. chima, chimaka, abinchi, tuwo*, jìbi*; much f. machiya; f. shared in common chiyăya; a calabash full of f. kabaki, pl. kabuka; remains of f. sanso, sudi, marmashi; to gather f. for the poor tarbata (S.).

fool, n. wawa, pl. wawaye, hauka, magagachi, afalalu, badada, bada-bada, dolo, gabo, hamsoro, limota (S.), loto, fem. lotuwa ; mai-wauta, mawauta, mahaukachi, fem. mahaukachiya, pl. mahaukata ; foolish talking badagula, they talked foolishly sun yi bobawa ; a f. who pays without counting ba-turen chacha. foolish, da wawa.

foolishness, n. wawanchi, hauka, mabuya, barkwanchi ; foolish talking badagula; tawa, gaga (S.).

foot, n. kূăfa, pl. ḳafafu, kafofi, kafuna; a f. regarded as a measure of length tāki, pl. tāke-tāke, tāki-tāki; a footprint sau, sawu; foot-rings munduwayen kăfa; sole of f. tafin lăfa, mataki, pl. matakai; tendons of . $\mathrm{f}$. matsarbaje (S.) ; on f. a ḳăfa; a f. soldier dan-kasa, sa'ati*. footman, e.g. a man who walks in front of a chief's horse zăgi, pl. zagagi.

footstool, mataki.

for, 1. prep. (for the sake of) domin, don; for his sake dominsa; see account of ; (in view of) $g a$. 
2. conj. (because) $f a, \approx a m a$. forbearance, n. hankuri, hankura, hakura, hakuri. forbid, tr. v. dakile, hana. force, n. tīlas, karifi; by f. da tilas, tilas, dole, doli; to use f. yin tîlas, tilasa (K.), tilasda (S.); phr. I was forced to go na tafi tilas or wajibi ne na tafi.

ford, n. mahayi, maketari, mashigi.

ford, to hayi.

forearm, n. găba, kusun-hannu, bauni (S.), pl. baunukka. forefather, n., see ancestor. forefinger, n. manuni.

forehead, n. goshi.

foreign, adj. ajami* ; f. (i.e. unintelligible) bobawa, baubawa, pl. bobayi ; f. speech bauchi.

foreigner, n. Ture*, ba-Ture ; that which pertains to a $f$. turanchi.

foresight, tānadi (S.).

foreskin, loba a, sulli.

forest, n. rukuki, daji, dăwa ; dense f. kurmi, kurumi, kumchi*.

forethought, n. hankali, tanadi (S.).

forge, n. (anvil) makera ; worker at a f. (blacksmith) makeri, mai-kira, pl. mukira, makeri. forge, tr. v. kìra. forget, tr. v. manche, shăgala da, yin mantuwa, manta. forgetfulness or forgetting, n. mantuwa, sakafchi. forgive, tr. v. yafe, yafe ma, gafarta, yin gafara, yarda; f. me ka yi mini gafara. forgiveness, n. gafara, gafarta.

fork, n. (iron toasting f.) rino, $r i n u$; the $f$. of a bifurcating stick gogfa, gwafa; a stick with a f. in it itache maigof $\mathrm{fa}$. forked, adj., a f. stick shishiniya (S.), shushiniya (K.); a f. iron stick on horse's neck kasagi.

forlornness, n. kewa, kiwa.

form, n. (shape) kama, supa*, sifa.

former, adj. nafari; the f.... the latter wanchan...wanchan.

formerly, adv. dazu, dafari ; in former times $n a d \bar{a}$; as in former times kaman na dā. fornication, n. shakalichi, fasikanchi.

fornicator, n. mashakalchi, shakali,bambagi, mai-fasikanchi. forsake, tr. v. bari, bar. forthwith, adv. nan da nan, ana nan, ko yanzu.

fortunate, adj., it was f. ya yi arziki; to be f. yin daula; see lucky. 
fortune, n. (prosperity) arziki, a man of $\mathrm{f}$. mawadachi, pl. mawadata; good f. gamonkatar.

forty, adj. arbaïn.

forward, adv. gaba; to move

a little f. guso, gurguso.

foster, f. mother uwal rufi;

f. child dangana*; one who fosters tallafi, gona; to act as a f. parent tallafa, taulafa.

foul, i.e. to make muddy gurbache.

foundation, n. gato, gindi; f. of a wall tushi, tushiya. founded, part. kăfaffe, fem. kăfaffiya, pl. kăfaffu.

fountain, n. maromaro, marmaru.

four, adj. fudu, hudu(Zanfara), pudu (Daura), arba'a*, arba*; by fours fudu fudu; four each furfudu.

fourteen, adj. goma sha fudu, sha fudu.

fourth, adj. na-fudu, fem. tafudu; f. day chitta.

fowl, n. $k \bar{a} z a$, pl. kaji; speckled fowls wakewaken kaji; a f. plucked for cooking shikir$k_{i t a}^{*}$; a place where fowls are kept akurki; a f. laying eggs dakwaluwa.

fox, n. longeared f. nyanyawa, yanyawa. fracture, kariya, karaya ; see break.

fragment, n. gutsura, pl. gutsure, guntu, guntun abu, fara (S.) ; f. of broken pots, etc. sakaina, tsingaro (S.), katanga.

francolin, see partridge.

frankincense,n. turare; small box for f. dan lulu; a tuber from which f. is made $k a j i j i$, gajiji; f. tree hano, ararra$b i$.

fraud, n., see deceit.

free, adj., one who is f. $d a$, diya.

free, tr. v. bari, bada diyauchi, yanchi, yantas, yauta da, diyanta, yanta, kwankwanche, săka, yin săki, sawanta.

freed, part. bararre, fem. bararriya, pl. bararru.

freedom, n. yanchi, diyauchi, diyanchi, diyantaka, săki, sawani; a certificate of $\mathrm{f}$. laya, layan diyauchi ; f. given to a slave on the death of his master mudăbar (S.), madabar.

frenzy, n. wāhami, hauka. frequent, adj., see often.

frequent, tr. v. (visit often) expressed by use of kan with verbs meaning to go to; he frequents the place ya saba da wuri. 
fresh, adj. sābo, fem. sābuwa, pl. sababbi; applied to plants, etc., fem. ganye*, danye, danya, pl. danyı or danyoyi. Friday, n. aljimma, aljimmu'a, jumma'a, jummu'a, jimma'a, jimmu'a.

fried, part. soyayye, fem. soyayya, pl. soyayyu.

friend, n. aboki, fem. abokiya, abuya, pl. abokai, abokanai, kawa ; masoyi, fem. masoya, pl. masoyu ; maso, pl. masowa; tsara, kama, pl. kamanu ; dan-uwa, pl. yan-uwa; zumu, fem. zumunya, juna, amini*, sahibi*, sahabi*, dangi, danga, pl. dangogi; makuabchi, pl. makwabta; friends tsarare; my friends yanuwana.

friendship, n. abuta, zumunchi, zumunta, halin aboki, shiriya, dan-dadi-dadi.

fright, n. tunzuru, tunzuruwa, tsoro.

frighten, tr. v. tsorata, bada tsoro, yin ruba, burga; to $\mathrm{f}$. or be frightened firgita, firgiche, razana.

fringe, giraza, geza; a f. for horses' eyes hutali, futali, furtali.

fro, going to and f. yauchi, $z \bar{a} g o$; to go to and f. zazzaga, zazzage, kai da kawo. frog, n. talibambam*, kwado, pl. kwaddi, kwadodi ; small dark coloured f. warnu; an edible f. burdudugi, burtutiki ; tree f. tsumbe ; bull f. kxozo.

frog-spit, or cuckoo-spit, kum$f a, k a k a s$.

from, prep. dăga; (when followed by the personal pronouns) dăga gare ; tun, f. birth tun haifuwa; f. within dăga chı̌ki; f. afar dăga nesa.

front, n. găba, pl. găbobi, goshi; in f. $a$ găba; in f. of găban; to go in f. tsaitse; go in f.! ku chi găba; he got in f. of us shi ya rŭga mu. front, to doshi, dosa, doso; he fronted them ya doshe su.

frontier, iyaka; a f. town kain iyaka.

froth, n. kunfa, kumfa; f. skimmed off in making bread, etc. Kulli, kullu; f. at mouth of a dying man dafara.

frown, intr. v. damre fuska, yin bakin (or bakar) fuska, jirkita fuska, murtsuka fuska. frowning, n. harāra*.

fruit, n. (of trees) dan itache, diyan itache, yayan itache; (of grains, etc.) lewara, kwaya; the f. of the earth diyan Kasa, yan kasa.

fruitful, adj., an epithet applied to corn mai-ido.

R. H. D. 
fruitless, adj., e.g. f. toil aikin wofi.

fry, tr. v. soya.

frying, suya.

fuel, n., see firewood.

fugitive, n. gujaje, mai-gudu, korarre, pl. korarru ; maguje, maguji, pl. magudane, maguda.

Fulah, pr. n., a F. native ba-Fillache, ba-Fillata, baFillatana, Fulata, pl. Fillani, Fulani; the F. language Fillanchi, Fulatanchi; the F. people Fulbe.

fulfil, to chı̌ka; to f. a promise chǐka alkawali.

full, adj. chı̌kakke, fem. chı̌kakkiya, pl. chǔkakku; a chike, fem. a chika, pl. a chiku; (f. to the brim) fau; see complete. fulness, n. yayalwachi.

funeral, n. biso ; lamentations at a f. makoki.

fungus, a club-shaped f. which grows on ant-heaps tumukun suri.

funnel, mazurari.

furbish, tr. v. (e.g. a sword) kuda.

furrow, n. kwări, pl. kwaruruwa, kwăre (S.), rumaniya ; to draw a f. karta; furrows on the cheeks karrara maya(S.). further, adj. (=more distant) mafi nisa. future, adj. (= that is to come) mai-zuwa; in f., adv. zuwa $g \check{a} b a$.

gadfly, bobuwa, bubu (S.).

gag, n. majanga.

gain, n. riba; unlawful g. kūra, riba, harāmiya; to make unlawful g. chin riba, chin haramiya, chin kūra.

gall, n. madachi, saifa, dwatana, ruwan dwatana; g. bladder matsarmama.

gallant, mai-dauki. gallantry, n. dauki. gallop, n. suka, pl. sukaikai; at a g. a sukwane.

gallop, intr. v. yin sukuwa, sukuwa, sukaya, sukayo, sukani, sukwani; a place for horses to g. masukwani, fage. galloping, a place for $g$. masukwani.

gambler, n. bakanchi, dan chacha; see ba-turen chacha. gambling, n., a game for g. chacha, alfowa, dăra, modi; to throw down money in $\mathrm{g}$. yin wasa da kurdi; see muzuru.

gambol, kiriniya, tsalle-tsalle. game, n. wargi ; games played by children karkachi, dare: găre, gyauga, lambe (S.), lai laya, langa, shillalo, tulatuki ubulunguwi, runfuki, wăha 
dokin wuya, zure, izgili; g. played by fortune-tellers in order to discover secrets dirka; a g. played with cowry shells dara; a gambling g. chacha; a call to join in a g. shu, shiyo, or shiyu ; a wrestling g. gumaza; a fencing g. takai, sharo. game, n. (food) naman daji. gaol, see prison.

gap, e.g. between two teeth wishiriya.

gape, intr. v. yin hamma. gaping, n. hamma.

garden, n. danga, pl. dangogi ; lambu, pl.lambuna, aljanna*. gardener, n. mai-gona*. gargle, n. wanken makoshi. gargling, n. kurkura.

garlic, n. tafarnuwa, pl. tafarnai; taparnuwa.

garment, n. riga, pl. riguna; old garments tsumma, pl. tsummoki, keso, pl. kyassa, ragga; see clothes.

garner, n. (a place for storing grain) rufogo, rafoniya, rumbu, rufewa.

sarnished, part. gyartache, fem. gyartachiya, pl. gyartattu.

sasp, intr. v. (for breath) yin fuka, shesheka, shashek $\alpha$; one who gasps mai-fuchi.

sasping, n. hăki (S.), shashaki. gate, n. l.ofo, pl. kofofi; gateway, see doorway.

gather together, 1. tr. v. tara.

2. intr. v. taru, gayya.

gathered, part. a tara, a taru,

tararre, fem. tararra, pl.

tararru.

gathering, n., e.g. of people

before a king kindigaye; see assembly.

gaze, n. kallo, tsokachi.

gaze at, tr. v. kallo, tsokachi, chokachi, dauro, doro*, nuri*, (generally in a bad sense) yin zuru.

gazelle, n., see antelope.

generosity, n. baiwa.

generous, adj. da kăra.

genii, n. jinnu; see demons. gently, adv. sanu, sannu, lako-

lako, săko-săko.

genuine, adj., g. money kurdi

tsaba.

Germany, pr. n. (used in

North Africa) Bursiya.

gesture, a g. expressing dis-

approval ambola, dakuwa.

get, tr. v. samu, same, sami,

sama, samo; g. out! je ka, fem. je ki; g. along ku yi ta tafiya.

ghost, n. fatalwa, magiro.

giant, n. gazaguru.

giddiness, n. gigichi, jiri,

hănani.

giddy, adj. phr. I am g. kaina 
shina kewayewa or ina jin jiri ; to be g. gigita; to make g. dāme, dāma.

gift, n. kyauta, kaya, pl. kayayaki, abin gaisuwa, baiko ; free g. alheri; g. given to conciliate tsaraba, see bribe ; gifts coll. baiwa.

gimlet, n. berīma, mararaki. gin, n. (for animals) tarko. gin, n. (a spirit) baraza, barasa. ginger, chitafo, chitan Afo. giraffe, rakumin daji, rakumin dăwa.

gird, tr. v. damre, daure, damra, yin damăra, darmi*. girded, part. damrarre, pl. damrarru.

girdle, n. damarichǔki, damăra, madamrin chiki,tamantaka*; a g. made with copper tagula, tugula, tagura ; a g. of cloth taraya ; a woman's g. gyauto, dan gyauto,jigida; a woman's g. of beads tsakiya, kwătana; a g. of cowries kiribi. girl, n. yarinya, pl. yam-mata, diya; a young g. tantabara. girth, n. (of a horse) bauji; a g. strap majayi, kaitaro. give, tr. v. $b a, b \bar{a} d a, b a s h i$, bayas, baya*; to g. back bayas da; to g. up bayas, bayar, sallame; bāda, bashi, yarda bashi*; to g. alms yin sadaka. giver, n. mai-bada, mabaya*. gizzard, of a bird kundu. glad, to be, intr. v. yin farinchiki, yin (or jin) murna. gladden, tr. v. bada (or $s a$ ) murna, faralta.

gladiolus, a wild rimana, rumana.

gladness, n. farin-chiki, murna.

gland, kaluluwa.

glass, n. mădūbi; a dish made of g. tamgaram, kwachiya*, pl. kwachaye; a looking-g. mădübin ido, matsokachi; the sound of falling $\mathrm{g}$. kitlin kĭlin, kĭri kiri, girin-girin. glean, tr. v. kālăta, yin kāla, rore, yin saura (or sabra). gleaning, roro.

gleanings, n. (of a harvest) $k \bar{a} l a$, saura*.

glorious, adj. (of God) jalla*. glory, n. daraja, darajiya, girma*.

glove, n. rigar hannu. glue, n. danko*.

glutton, n. mai-loma, machi, pl. machiya, mai-rida, mafălashi, mai-kwaraka. gluttonous, zwari. gluttony, mayin chi, zwari, zari; see greed.

gnash, tr. v. tamna hakori. gnashing, n. (of teeth) tsukun hateori. 
gnaw, to chisga, chizga, gurgura.

go, intr. v. tafi, je, zaka, zatsa*, to be about to go $z a$; to go round a place ziyara, zaga, zagi; to go before gabāta, gabāche; to go forth fita; to go away kau; to go constantly to a place shishiga; to go as far as tusga, tusge; go with a person tare; to go to meet tariye; go out of fita; to go by night $b i$ dare; to go after a wife in order to bring her home biko; phr. go on with what you are doing yi ta $y i$.

goat, n. akwiya, akuya, akwuya, pl. auaki; he-goat bunsŭru, pl. bunsŭrai or bunsŭraye; a young g. burguma ; a longhaired species of $\mathrm{g}$. buzuruva ; a speckled g. gitsawa (S.), gwalande; a vicious $\mathrm{g}$. watsatsi, fem. watsatsiya ; old lean g. guzuma; a castrated g. tabre, taure; beard of a g. rairo, rero; a g. in milk karduwa.

goat-sucker, see night-jar.

God, pr. n. Allah, the plural allohi is used of idols.

going, part. tafiya; they are g. suna tafiya; a g. away maraita*.

gold, n. zinariya. gonorrhoea, chiwon sanyi, masuna, fyauka. good, adj. năgari, fem. tăgari, pl. năgargaru, mai-kyau, kyau, kekyawa, salihi; phr. g. or bad fari ko baki; g. used as an exclamation to ; g. morning sanu da safe, sanu da rana; g. evening (on parting) sai da safe, (on meeting) sanu da dare ; goodbye for the present sai an jima; g. news albishir; g. news for you albishirinka; a g. disposition kyakyawan hali; something g. abin $k i$ riki; see under sanu. good-bye, to say ban kwana. goodness, n. nagarta, nagarchi, kyauta ; (of flavour, etc.) zaki.

goods, n. dukiya, pl. dukoki or dukiyoyi ; kaya, pl. kayayaki; g. for sale haja, faja* ; (property) tarkache.

goose, n. dumya, dinya; a wild g. $g \bar{a} b \alpha^{*}$. gore, n. jini.

gore, tr. v. (of horned animals) tune, tunkuda, tunkuji or tunkwiyi, e.g. the bull and the cow gored each the other sa da saniya suka tunkuda junansu; soka, soke or soki with intens. sossoke. gorge, n. 1. see throat. 
2. (a narrow defile) kwa$z a z z a b o$.

gorgeous, adj. (splendid) na ado, e.g. g. robes riguna na ado (or masu-kawa).

goro-nut, n. goro, pl. gwarra; see kola-nut.

gory, adj. da jini, na jini, sai jini.

gospels, the linjīla.

gossip, n. 1. (talk) raushi, roshi, tadi, waiwai, algungumanchi, kwarmato, azuzanchi, hira.

2. concr. an idle talker, a gossip algurigumi, pl. algunguma, aziиji, sururi (S.). gourd, n., a plant whose fruit is either eaten or formed into cups and calabashes; among the various kinds which are eaten are kabèwa (K.), kubeua (S.), goji, kabus, karamiya; among those used as vessels are kwariya, korya, kurtu, masaki, maseki, and duma; see also baska, gŭro (S.), jallo (K.), tsana (S.). gourds, roots of, coll. n. yado. govern, v. (rule, reign) mallaka; see rule.

governor, n. hākimi*, pl. hakimai, masarauchi, wakili; sariki is sometimes used in this sense.

gown, n. riga, pl. riguna, salaha; the body of a $\mathrm{g}$. as opposed to the sleeves (hannuıva) uwar riga.

grace, n. (favour, free gift) jinkai, aikin gafara, alhēri, kyauta; he showed g. to us ya yi ma mu alhèri.

graceful, da nasiya, da nasiha. gracious, adj. (of God) karīmu; good g.! haba mana. grain, n. 1. Kwara, kwwaya, pl. kwarori; g. that springs up of itself gyamro; g. which has been kept a long time suna; g. which has been husked surfe.

2. fig. grains (as of sand) barbadi.

grain, receptacle for, n. taska, pl. taskoki, rufogo (K.), rafoniya, rufewa (S.), rumbu, tsunjiya.

grammar, nahau, nahauri; one who is learned in $\mathrm{g}$. malamin nahau.

grand, adj. (important) $b a b b a$,

pl. manya; mai-girma, pl. masu-girma.

grandchild, n. jīka, fem. jīkanya, pl. jīkoki, jīkannu; a great g. tabakunne. granddaughter, n., see prec. grandfather, n. kāka, pl. kakanni, uban uba, e.g. your g. uban ubanka.

grandmother, n. kākanya. 
grandson, n., see grandchild. grapes, forest g. tsibir-kinkini, clibir-kinkini.

grasp, with the hand, tr. v. jimka, vumchi, rumtse, jimke; with the arms (to embrace) rungume.

grasping, adj. fig. (covetous, greedy) da rowwa, marowachi.

\section{grasping disposition,}

n. rowwa, kawazuchi.

grass, n. 1. gen. chīyawa, pl. chīyayi, yayi, haki, pl. hakīkuwa; green g. chīyawa, lanye, hăki, pl. hăkuvva ; green g. which has recently sprung up tsatse (S.).

2. spec. of various kinds and uses: Bermuda or dubs. kiri-kiri or tsirkiyar zomo; comb fringe g. gude-gude; cuscus g. or Vetiver g. jema; elephant g. yambama, hambama, dawar kada; prickly bur g. karangiya; Spanish reed g. gabara; a grass used for filling cushions roba, pl. roboba, robuna; a g. appendage worn by certain pagan tribes takatsara; dried or chopped g. for horses ingirichi or ingirochi; undried g. as fodder kansuwa, kyasuwa, komayya; a $\mathrm{g}$. eaten in times of famine
(Eragrostis tremula) bumburuwa, bubburwa; a low coarse g. birbiro, birobiro; a $\dot{g}$. eaten by horses gadagi, garaji, lambusu; a g. for making brooms tsintsiya; plaited g. tsaiuca, tsaua; a soft hairy g. yan-hutu; g. used for thatching shifchi, yăma, yantso, būnu, pl. bünai, daudau; a g. used in making mortar datsi; a g. shelter or hut $d a b i$ (S.) ; see also bunsurun daji, gazama, karareyo, machara (K.), tuji (Eleusine indica), burgu (Panicum sp.), harkiya or harikiya (Digitaria debilis).

grasshopper, dindiba, dunkurkuda; green g. askalaya (S.) ; spotted g. wukar sariki (lit. king's knife).

gratitude, maida yirma. gratuitous, adj. banza. grave, n. kushewa, kusheya*, pl. kusheyi, kushewoyi, makuanchi,kăbari, kabri, wurin bisne, wurin kushewa.

gravel, n. tsăkuvva. graze, v. 1. tr. kiwo.

2. intr. of cattle id.

grease, n. mai.

greasy, to be or become nāshe, $n \bar{a} s h i$.

great, adj. 1. (both physically and morally) $b a b b a$, pl. manya 
or maya, mai-girma, da girma; a g. king sariki babba or babban sariki; very g. (very important) mianya manya.

2. (quantitatively and of degree) da yawa.

3. spec. applied to God jalla*, jalala*, akbar**.

4. of one in authority as a king or prince madaukaki.

great, to declare g., v. 1. (to honour) girmama.

2. kabbar*, e.g. to declare that God is g. kabbar ga allah akbar.

3. to be g. bunkāsa, kasaita. greater, adj. comp. mafi-girma, pl. masu-fi-girma; in the absence of superl. forms the idea is expr. by phr. ya $f i$ duka or ya fi kowa appended to the adj.; he was greater than he ya fifiche shi.

greatness, n. girma, zati. greed, n. rowwa, marowwachi, tsumulmula (K.).

greedy, adj. da rowwa, zargi, bahilchi, mayinchi, hadama, kanwa, kwalama, machi, zwari, makwadaita, mai-kwaraka, mafălashi, mai-ḳurmusu*, marowwachi.

green, adj. 1. (the colour) algashi, fem. algasa, pl. algasai, algasu, tsanwa, chanwa; dark g. kore, fem. koriya, pl. kwarrai; light g. kore-kore; g. esp. applied to g. dyed leather korino.

2. (fresh) of plants etc. danye or danyi, pl. danyoyi, danyu.

greet, tr. v. 1. gaida, gaishe, gaisa, yin fawo, e.g. I greeted the man and he accepted my greeting na gaida mutum ya karbagaisuwata ; we g. muna gaisuwa; I g. thee a gaishe $k a$.

2. (of religious salutation) yin salatu; we g. muna salmawa.

3. to g. by shaking the hand jinjina; to wave or extend the hand in greeting mika hannu, e.g. I greeted them with my hand and departed na mika ma su hannu na tafi.

greeting, n. gaisuwa.

grey, efo, turning g., as from age furfura.

grief, n. 1. (pain of mind, sorrow) nadāma, ladāma.

2. (cause of pain or sorrow) wahala.

3. (expression of grief) $k u k a$, e.g. he made great g. over him ya yi kuka dayawa a bisansa. 
grieved, be, intr. v. wahalda, jin wahala.

grimace, a gualo, kogama, zumde.

grind, tr. v. 1. gen. nǔka, tǔsa, tushe, reda, dăka, intensive to g. to powder daddăka, dandaka, daddăga; to g. thoroughly barza; to g. rice etc. tingama.

2. (to whet or sharpen) wasa, gyarta.

grinding, of wheat, n. esp. used of regrinding barzawa, tŭshi. grindstone, mawashi, niki; a stone for smoothing a $\mathrm{g}$. makodi.

grip, to kwakwume, damka ; to g. the throatkwakwume wuya. gripe, tr. v. (of medicine) murcla.

gristle, n. gurunguntsi. groan, intr. v. yin, nishi. groaning, n. nishi.

groom, n. 1. shamăki, pl. shamakai, dan muri, dan turke.

2. (bridegroom) ango, $\mathrm{pl}$. anguna.

grope, v. lalabe, mămare; (to search one's way with the hands in the dark) burkuti, bulkuchi, dundumi.

ground, n. 1. (surface of the earth) kăasa; on the g. a kăasa or a kas ; hard flat g. kekuwa.

2. (cause) sababi or suba- $b i^{*}$ without g. (or grounds) babu sababi.

3. (first principle or foundation) gutsu.

ground, to (of a boat) kăfa. ground, pass. participle 1 . (finely) raushi, roshi, rabshi.

2. (roughly) da tsaki; badly ground flour barzo. ground-nut, n., i.e. Arachis hypogaea gyadla; a smaller species of g.-n. gujiya, pl. gujiyoyi,gujeye; oil extracted from g.-n. man gyada. grouse, sand-g. barwa, kwantatoi, suwaka, ladin rogo. grow, intr. v. 1. of plants tšra, tš̆re, tš̆ro, chira.

2. to increase in size girma, yin girma.

3. to g. (i.e. to become) zama; to g. old tsufa. growing, mătāshi. growl, to (of a lion) babbaki. growling, gurnani, ruri. grown, full g. rikakke, ḳasaitache.

gruel, n., made of guinea-corn

kunu; a thin g. salala.

grumble, v. yin gunaguni, yin

guri, yin bimbini. grumbling, n. bimbini, bibini, zargi, ğ̌nagǔni. grunting, (of a pig) n. tsuvva. guarantee, to lamunta. guard, n. 1. (heed, care) tsari, 
e.g. be on your g. against ka nema tsari.

2. (soldier of king's bodyguard) dakare, pl. dakaru, dogari, pl. dogarai.

guard, tr. v. tsăra, tsări, tsăre, tsăro,batāka, ritse, rutse, ratse. guardian, mai-tsari, mai-tsaro. guard-room, jar u*, jarum*. guest, n. baḳo, fem. bakuwa,

pl. bakuna, baki or bakokuna. guide, n. jagaba, shugaba, pl. shugabai, koranga (K.), majan-hanya.

guide, tr. v. (lead, - conduct)

kai, bida, bishe; (to instruct) galgade, gargadi.

guile, n. munafuchi, munafunchi, or manafuchi ; (cunning) wayo, with g. da wayo. guilt, n. laifi. guiltless, adj. babu laiti, maraslaifi.

guilty, to declare, v. kada, bada laifi, kayas*. guinea-corn, n. dāwa (Sorghum vulgare), tsaba (S.), gero*. There are four chief kinds of dāwa: kaura used for feeding horses, farafara, farfara used when ground for making gruel, murmura or muramura* eaten whole when cooked, giwakamba used as a medicine for rubbing on the eyes; the red or grey g.-c. with closegrowing head janjare; husks of g.-c. kwardo; g.-c. pod tsirgagiya; an intoxicating drink made from g.-c. giya; g.-c. fever, occurring when the g.-c. ripens chiwo na sabon dāwa; g.-c. which has sprung up in an unsown farm kakarya; see badawa, dan-jigāuwa, gangariya, malle, shinkafar-talaka.

guinea-fowl, n. zabo, fem. zabuwa, pl. zabi, kazar yaraba; cry of the g.-f. kilkal, kukui.

guinea-pig, beran turawa. guinea-worm, n. kurkunu, girgamo ; a small plant used as a medicine for g. damar$k a ̆ d a$, dumankăda; a swelling caused by g. hangara. guitar, n., a kind of kofsa. gullet, n. janai (S.), janyaro (K.).

gully, a dry g. kozazzabe, kwazazzabo.

gum, n. danko, jirai; spec. a g. put in ink kāaro; a g. used in perfumes karon maje, bafur; gum-bearing trees chiriri, dakwara, düli, dumshe, dundu, karḳara, kwwarkwara, fara kaya, taura. gums, n. (seat of the teeth) dāsashi (K.), dasori (S.). 
gun, n. bindiga, pl. bindigogi; adakka*; a double-barrelled g. bindiga da baki (or maibaki) biyu, tagwayen bindiga ; to load a g. dora or chika bindiga; to discharge a $g$. halbi (or halbe or buga) bindiga; flint of a g. kankara, dutsim bindiga; report of a g. kărar bindiga, ămo; a flint-lock g. mai-kamsir, mantampas (S.); a maxim g. mai-ruua*; a long-barrelled Arab g. scuaila, tsawila.

gunpowder, n. albarus or albarushi.

gush out, intr. v. zuba, zubo; to g. out abundantly gushegushe.

gusset, n. tsumma, pl. tsummoki; cloth g. in a tobe stiga.

gypsum, n. aljŭbus, alž̆bus.

habit, n. ta'ada, tāda (S.), pl. tadodi, ada, hali, kabiya*, $s a b o^{*}$, the last especially of aptitude acquired by practice, phr. nothing can be done except by practice aikin duniya duka sai sabo; see habituated.

habitation, n. mazamni.

habituated, to be, intr. v. saba constr. with $d a$.

haggle, intr. v. yin chiniki, tallata, yin talla; see bargain.

haggling, talla.

hail, n. kanḳara, ruwa da kankara.

hail ! exclamation $=$ welcome $!$ sanu, a gaishe ka, sai lafiya. hair, n. gashi, pl. gasusuwa ; spec. head of $h$. when cut off suma; h. on the cheeks saje; h. of tail of horse, elephant, etc. tsagiya ; abundance of h. gizo; absence of h. on head kundumin kai; long ridge of $h$. left in shaving shasanda; tuft of $h$. in the middle of head zanko; h. of woman plaited bijaji, bujaji,buji-buji; h. worn by women in curls down their cheeks kitso; twisted locks of woman's h. at side of face dauri; grey h. furfura; h. on cheeks and upper lip washēfe; h. tied in knots with a ridge in the middle shetambuwa; a head of h. sura* (S.); a tuft of $h$. of a young man toliya; the h. came off gashi ya tŭshe.

hairdresser, n. mai-kitso, fem. makitsiya, wanzami, maikalmishiya.

hairy, adj. da gashi, e.g. its face is all h. fuskassa $d u k d a$ gashi or fuskassa sai gashi; 
a h. person galgasa, gargasa;

h. all over duguza.

half, n. shashi, shashe, sashe, răbi, nusufi*; h. a piece of cloth, paper, etc. aussagi, bāare. hall, n., entrance h. zaure, pl. zauruka.

halt, adj. gurgu, pl. guragu, makasari.

halt, intr. v. 1. (to limp) yin gurgunta.

2. (to stop marching, to stand still) tsayi, tsaya, tsai.

3. spec. to $h$. for the night shida or shide.

4. fig. to $h$. between two opinions yin zuchiya biyu. halter, n., also a leading-rope for horses, etc. ăsalwayi, răgama.

halting, n. tsayi; (limping) gurgunta, gurmunta, gurgunchi.

halting-place, for the night, n. zango, mashidi, the last in the sense of a lodging or khan ; spec. temporary h. for carriers loko.

halve, tr. v. bare, bara; in less strict sense (to divide) raba.

hamlet, unguwa, anguwa, tŭnga, pl. tungaigai.

hammer, n. kwarikwasa*; a blacksmith's h. masāba, pl. masābai; a large h. amadeshi*; a small h. matalaga, muntalaga; h. of a gun kunāma.

hammock, rāga*.

hand, n. 1. Һӑnnu, pl. hănnu$w a$, hannaye; the right $\mathrm{h}$. dama or hannu na dama; the left h. hagum, hagu, hauni, hannu na hagum or hănnu na hauni; the palm of the h. tăfin hănnu; the back of the h. bayan hannu.

2. of place or direction, right h. dama, wajen dama; left h. hagum, hagu, hauni or wajen hagum, etc.; of time, at h. kusa, da kusa; to raise the h. chira hannu; see hands.

handed, left-, adj. bahago.

handful, n. (of mud, flour, etc.) dunkule, churi, damka, jimki; to take a h. jimke, chura, chibra (S.), damke, dimtso, jimka.

handkerchief, n. maharma, maharama, adiko, mai-yani, mayani; spec. a $\mathrm{h}$. on woman's head kallabi; h. to bind round woman's head alfuta, pl. alfutai.

handle, n. mariki, pl. marika, makāma, madauki, maratayi; $\mathrm{h}$. of axe bakin gatari, bota (Kats.), kota (K.) ; h. of box makama, kota, zoben kaya. handle, tr. v. tăba. 
hands, to clap the, v. tafa, tafi, tabi (S.); to shake h. yin musafilua, ban hannu.

hands, a man with his h. tied to his neck, n. kukumtache, pl. kukumtattu; the tying of a man's h. kukumi, kunkumi ; shakingh. masafiha, musafiha. handsome, adj. da kyau, maikyau; a building h. to look at gida da kyaun gani.

hang, tr. v. rataya, rataye, yin rataya; to h. up rataya, yin rataya; to h. up meat done, kere.

hanging, n. (curtain, etc.) reto, rataya.

hanging, n. (e.g. h. up of curtains) yani.

hanging, 1. adj. (suspended) a rataye.

2. part. ratayawa.

hank, of yarn sulu (S.).

happen, intr. v. 1. afku, abku, faru, e.g. it happened ya faru, what has happened? mi ya faru?

2. (i.e. befall) same, sama, sami, samo, gudārua, e.g. what has happened to you? (i.e. what is the matter with 'you ?) mi ya same ka?

happiness, n. 1. (satisfaction) dadi, dadin zuchiya, alhēri, murna*, fărin-chřki, gatanchi.
2. (in a religious sense) sa'ada*.

happy, feel, intr. v. jin dadi. harass,tr.v.tsananche,tsananta. hard, adj. 1. phys. tattaura, fem. tattauriya, da tauri, tsandauri; see seq.; also morally hard, obstinate.

2. (difficult of accomplishment, etc.) da wuya.

harden, 1. intr. v. (to become hard) yin tauri, taurare.

2. tr. v. to h. taurata, tsaurata, yin tauri.

hard-headed, n. (an obstinate person)mai-kin ji, mai-taurin zuchiya.

hardness, n. tauri, tsauri (Zanf.); also in a moral sense, e.g. taurin zuchiya h. of heart. hare, n. zomo, pl. zomai. harlot, n. shakaliya, pl. shakalai; sarkachiya, bombegi* ; child of harlot dan-farka.

harlotry, n. sakarchi, shakalchi. harm, n. banna, laifi, e.g. there is no h. in it babu laifi.

harm, tr. v. lata, bache.

Harmattan wind, iskan buda. harpoon, n., for river tishing zăgo, hagu, margi; an irontipped h. fired from a gun sango.

hart, n., see deer.

hartebeest (Damaliscus Senegalensis) dări ; West African 
h. kanki, pl. kanoki, kankuna.

harvest, n. girbi, (i.e. the season) kaka.

harvest, to cut down the, v. girba; see reap.

haste, n. sauri, samri, anniya, garaje.

hasten, intr. v. yin anniya, hanzarta (K.), hamzarta, hamzanta (S.), kwarare, gaugata, gagauta, gagawa; to h. after zazari; h. to catch up $k u$ chı̌ka; to h.; i.e. to accelerate hamzarta.

hastening, n. garaje, gaugawa. hastily, adv. da sauri, da hamzari.

hat, straw, n. gurumfa, garum$f a$, garunfa; a large straw h. mālafa, malfa, pl. malafuna, malafai; dan gurumfa designates a small trader, who carries goods on his head; see cap.

hatch, tr. v. kyankyashe, kyankyasa*.

hatchet, n. gātari, pl. gātara, gātura, gāturuwa, gāfiya, walwada, warwada; small h. dan gatari; handle of a $h$. bakin gatari; spec. small h. for cutting grass for fodder kurăda, kuradda; h. with broad blade barandami, tsitaka. hate, n. ḳiyeya, ḳiyaiya, ḳiyo, kiwo.

hate, tr. v. ki, kiya*.

hater, n. ag. makiyi, pl. makiya. hatred, kiyaiya, see anger.

haughtiness, n. fâdlin rai, fädin zuchiya, girman kai, girman rai, homa, foma, toma. haughty, adj. da givman rai, tomo.

haul, tr. v. $j a$.

haunch, n. (of a cow) kwankwaso.

Hausa, pr. n., the Hausa nation, country, language Hausa; a $\mathrm{H}$. native ba-Haushe, pl. Hausawa; the $\mathrm{H}$. language Hausa, magana Hausa, halshen Hausa, after the manner of the Hausas Hausanchi, I understand $\mathrm{H}$. ina jin magana Hausa, to speak $\mathrm{H}$. yin magana Hausa; see language.

have, tr. v. (to possess) $n a d a$, ke $d a$, also expr. by ga (to), or with pronouns gare, e.g. I h. a friend named Hassan ina da aboki sunansa Hasan, a certain man has a camel wani mutum shina da raker$m i$, we h. $m u k e d a$, I h. much money kurdi dayawa gare ni.

haversack, amasai.

hawk, n. shirwa, pl. shirwoyi, 
or shirwuna, karamăta, tankarki, tsinkaki, shahu*, shafo; swoop of a h. bara, sura.

hay, n. baro, ingivichi, ingirochi.

haze, n. hazo, lịasashi.

hazel nut, n. chanza.

hazy, adj. da hazo.

he, pers. pron. shi, ya, yi, $i^{*}$; $s h i$ is emphatic and used as separate pron. before ya, e.g. but my brother he saw her afar off amma kanena shi ya gan ta $d a$ nesa, it is also used with dependent clauses and wishes; $y a$ is used in the aorist and in impersonal expressions as $y a$ isa it is enough.

head, n. 1. (of animated beings) kai, pl. kanuwa, kawana, kawuna.

2. (chief point or substance of a statement) $\mathrm{kai}$.

3. (chief person) see chief; back part of h. keya; a man whose $h$. protrudes at the back mai-kyeya; a person with a large h. mai-kai; standing on the h. rimi; to hang the h. sunkwiya da kai (K.) ; leaning the $h$. on the hand in token of distress tagumi.

headache, n. chiwon-kai, jiri, jeri. head-dress, n. rawani, pl. rawunna; (of a woman) fatala, patala.

headlong, adj. and adv. $d a$ gangara; to fall h. sulla $d a$ kai, fada da kai.

headman, 1. (of a village, place, etc.) sariki or sarki, q.v., dagachi, pl. dagatai, kunduda, makwayo, haki$m i *$.

2. (of a caravan) madugu, pl. madugawa.

heal, tr. v. warke, warkad da; pass. to be healed warke and the pass. form, e.g. remain here until he be healed $k u$ zamna a wurin nan sai ya warke or sai a warke shi.

healed, particip. (h. in body or restored in mind) warkakke, fem. warkakkiya, pl. warkakku.

healing, warkasuwa.

health, n. (i.e. good h.) läfiya; in h. läfiya and da lafiya, frequently used in salutations, e.g. are you in h.? kana läfiya? answ. in very good h. laffiya lau; to be in good h. yin lafiya; to improve in h. jin dama, warware; restoration to h. afuwa; he recovers his $h$., he becomes better ya samu afuwa (or lafiya), ya jirangwame; one 
in bad h., sick, a patient maras-lafiya.

healthy, adj. lafiyaye.

heap, n. taro or taru, pl. tarori, tüli or tulli, pl. tuloli, kitila; a h. of branches, etc. zubugi. heap up, tr. v. hada, dora; spec. to h. up earth round plants firi, furi, yin maimai, q.v.

hear, tr. v. $j i$.

- heart, n. 1. (the bodily organ) zuchiya, pl. zukata, zuchiyoyi, zutochi or zukochi, gaba*.

2. (the feelings) zuchiya, e.g. zuchiyata ta bache my $\mathrm{h}$. was broken; to be cut to the h. jin zafin zuchiya; to learn by h. samu harda; to know by h. yin harda, hardache; to say off by h. yin tulawa; they lost $h$. hankullansu duka sun tashi.

heartburn, kwarnafi, kwannafi.

heartless, adj. magaya or magauchi, pl. magauta or magata. heat, n. $z \bar{a} f i, z u f a$; spec. h. of the sun gumi.

heathen, n. arne, pl. asna, azna, arna; kafiri, pl. kafirai and kafirawa; majusi, pl. majusawa; ba-Maguje, pl.Maguzawa. heathenism, n. kafirchi*, $k a$ furchi*, halin kafirai*, asnanchi, aznanchi, arnanchi. heave, tr. v., to h. a sigh aje zuchiya, yin sheda.

heaven, n. săma, pl. samaniya, sammai, samomi, gidan dawama ; h. and hell (the afterworld) lahira; the Mohammedan paradise aljanna.

heaviness, n. (great weight) nauyi.

heavy, adj. da nauyi, mainauyi.

heddles (of a loom), allera, annera (S.).

hedge, $\mathrm{n}$. (fence) darni, danga, damfămi, shimge, shinge, $\mathrm{pl}$. shimgaye, kiliya.

hedgehog, n. bushiya, baushiya, babagumi.

hedges, a plant used in making,

n. fidda sartse, bi-ni-da-zugu, chi-ni-da-zugu.

heed, n. tsări; take h. nema tsări.

heed, v. 1. (to take notice of anything) küla, tuna, tunane, all constr. with $d a$.

2. (to attend to what is said) saurara, $j i$; spec. to take $h$. to an agreement, etc. damre magana.

heel, n. dudduge or diddigi, duga-duga, pl. dugadugai, dunduniya.

heifer, karsana.

height, n. tsava, tsawo, tsai, tsayi, hawa, e.g. it is three 
cubits in h. tsawonsa kamu $u k u$.

heir, n. magadi, magaji, pl. magata, magada, māmayi; h. to the throne chiroma, yarima; $\mathrm{h}$. to the throne majiran gado, at Kano wambai, daudu, dauda; to have as h., i.e. to be succeeded by $g \bar{a} d a d a$.

Hejira, the, n. hijira. held, particip. rikakke, fem. rikakkiya, pl. rikakku.

aell, n. jahannama, jahīma; h. and heaven (the future world) lahira.

iell-fire, n. jahìma.

relmet, n. bushiya, kwalkwali, buke.

ıelp, n. tamayi, taimako, taimakawa, sauki, agaji, agaza, shalli, tanyo (Zanf.) ; h. especially in war gudummuwa, gudummawa, gudunmawa ; to ask for h. zukatta; to obtain h. samu sauki; to send h. koro sauki.

lelp, tr. v. taya, tanya (S.), tanye, tanyo, yin taya, taimaka, taimaki, taimake, tamaya, yin taimako, agaje, sauki, sauwaka, sawaka, yin shalli; to ask for h. găyato.

lelper, n. ag. mataimaki, matanyi, abokin tayo.

tem, n. lafi or lafe shafi, R. H. D. shafe; to make a h. kalmă$s a$, kalmashe; to h. round dāje.

hemorrhoids, bāsur.

hemp, African bowstring $h$. moda; Indian h. rama.

hen, n. kāza, pl. kaji; a hen laying eggs daḳwaluwa, daluvalwa; the Hen and Chickens constellation which appears when the rainy season is coming kaza mai-yaya or kaza da yaya.

hence, adv. dăga nan, dăga wurin nan.

hen-coop, n. akurkin $k \bar{a} z a$, akurki.

henna, lalle.

her, 1. possess. pron. suffixed

to a masc. n. -nta, suffixed to a fem. n. -lta, -rta, e.g. h. daughter diyarta, h. camel rakuminta; used separately if the object possessed is masc. nata, if fem. tata, see H. Grammar ; these stand also for Engl. 'hers.'

2 . pers. pron. objective suffixed to verbs and preps. -ta, e.g. he saw h. ya gan ta, to h. gare $t a$; and separate (after prepositions) ita, e.g. he returned along with h. ya komo tare da ita.

herb, n. (green blade) ganye, fem. ganya, pl. ganyaye. 
herd, n. garke*, garge (S.), pl. garkuna.

herdsman, n. makiyayi, pl. makiyaya, makyayi, pl. makyaya.

here, adv. nan, a wurin nan, dăga nan, the latter also= from h., from this point, e.g. do you know the way from h. ka sani hanya dăga nan ko?

hereditary, an h. profession, chinikin gŭda.

heretofore, adv. (until now) har yanzu; h. I have not heard this dadai ban $\ddot{j}$ wannan ba; as h. kaman na $d \bar{a}$; see ever.

hermit, mai-halwa*, mai-kiyamal duniya*, sufi*

hero, gamzo.

heron, n. zarḅi, zarbe, zalbi; great white h. or egret farin zarbi; see egret.

hers, separ. possess. pron. nata, tata; see her.

hesitate, intr. v. yin zuchiya biyu.

hesitatión, n. zuchiya biyu.

hiccough, n. shăkuwa, chiwon shăkuwa.

hid, to be, v. boye, boyi.

hidden, particip. boyaya, boyu, rufaffe, fem. rufaffa, pl. rufaffu.

hide, n. kilāgo, pl. kilāgai; kilabo, lkirgi, the latter used of $\mathrm{h}$. after tanning, the untanned $\mathrm{h}$. is called fata.

hide, 1. tr. v. rufe, rufi or rife*, boye, boyi, sakaye, sulle.

2. intr. v. (to hide oneself) boye, boyi, lăbe (S.), rabe (K.), făke, see ambush; to $\mathrm{h}$. behind a person in fear rafake, ranfake, rampaki; to h. oneself boyo; to h. right away or completely bobboye. hiding, n. boyewa.

hiding-place, n. maboya, maboyi, mafaka, fako* ; a place for hiding or laying up anything ma-aje, ma-aji.

higgle, v. talla*.

high, adj. dogo, fem. doguwa, pl. dogaye, da tsawo.

hill, n. tudu, pl. tudodi or tuduna, tsauni, pl. tsaunoni, tsaunaye, tsaununa; a $\mathrm{h}$. covered with sand jiggawa or jigawa, pl. jigawoyi or jigawuna; hillock burji, birji.

himself, pron. both emphatic as shi da kansa, and also reflexive, e.g. prov. he who weeps for another weeps for h. kowa shi ke kuka da wani shi kuka da kansa.

hinder, adj. na-baya, fem. ta baya.

hinder, tr. v. hăna, kwabe. 
kwaba, kwabo, laruranta, tankosa, tankwasa.

hip-bone, n. kătăra.

hippopotamus, n. dorina, pl. dorinai or dorinnai.

hire, n. (wages) lada, sŭfuri, alāro, ijāra; a hired labourer kwadigo, dan kwadigo; a person seeking h. mai-koda; to work for h. yin sufuri.

hire, tr. v. yin sufuri, sufurche, sufurta, sufurchi, jinganta, ijarta.

hiring, n. ijarchi.

his, possess. pron. suffixed to a masc. n. $-n s a$, suffixed to a fem. n. -lsa, -rsa, e.g. h. camel rakuminsa, h. mare godiyarsa; as separate pron. if the object possessed is masc. nasa or nai, if fem. tasa or tai.

aiss, intr. v. yin fuchi.

aissing, n. shishita; of snakes fuchi.

aistory, tāriyo*.

iit, tr. v., see strike.

ither, adv. nan*, ga wurin nan*.

10 ! interj. to call attention kai.

loard, to tsimi da.

lobble, a rope used to $\mathrm{h}$. horses, n. dabaibayi, dabaibiya (S.), tabaibayi, tarnăki. obgoblin, n. fatalwa. hoe, n. fatanya, fartanya, hau$y a, \mathrm{pl}$. hauyu, hauyuna or hauyoyi, mashemi, kyante, kuruga; spec. a large $h$. bent like small plough galma (S.), garma (K.); a longhandled $h$. with triangular blade kŭmbu, kŭmbuwa ; a h. with long handle and broad blade used for cutting stubble kwasa; a h. used as a dibble sungumi.

hoe, tr. v., to dig or stir the ground noma, nomi, nome, chira, furi, firi, fuda, hüda ; to cut down grass with $a \mathrm{~h}$. shema; the first hoeing after sowing gwarzo (S.), turbe, chirbe (Z.) ; the first hoeing before sowing kaftu, kabtu, kufurtu; clearing ground for hoeing $z \breve{a} f a$ (S.).

hoed, nomamme, fem. nomammiya, pl. nomammu.

hog, n., see pig.

hoist, to h. a flag cliira tuta bisa.

hold, tr. v. rika, rike, riki, riske, riski, ruska, aje*, e.g. he held the door ya aje kofa; to h. fast in the mind rike, rika, riki ; to lay h. on kama ; to h. up at arm's length dăga ; to h. back turke, zamne* ; to h. the breath hadiye (hade or dauki) lumfashi. 
holding fast, n. rikawa.

hole, n. rami, rame (S.), pl. ramuna, ramu, kwarmi, pl. kwarmu, bariya or babbariya (S.), faffago, făgo, fuji, kurfi, pl. kurfofi, kurfu, pampama (S.),mashiga, sāra; $\mathrm{h}$. for game to fall into hăko, pl. hăḳōki, bima; a h. for dung kwakwari, masai, salga; a back entrance to a fox or rat h. buga; a h. in which grain is planted kamfa; a h. in a wall kusfa, kusuwa (S.); h. where dirty water is thrown katami, kwatami; a h. to look out at taga; h. for storing corn tsunjiya; h. made in nose of ox for rope asirka, zari; h. for entrance $k o f a ; \mathrm{h}$. in a seam barāka; to make many holes huhuda, fuffuda.

hollow-backed, adj. gantsarwa.

holy, adj. da tsarki; a holy man sharif.

homage, n. chaffa, chappa, mubaya, mabaya.

homage, to do (by kneeling down) intr. v. durkusa, yin chaffa.

home, n. gĭda; at h. chǔkin gřda.

honest, adj. mai-gaskiya, da gaskiya ; an h. man mutumen gaskiya. honey, n. zümmuwa, zŭma, ruwan zummuwa; a stick of h. algarwai.

honey-guide (bird), gunda, maganiya, dan zuma.

honour, n. yabo, daraja, darajiya, manyanchi, mayanchi, girma, daukaka.

honour, tr. v. yin yabo, girmama, bāda girma, ba (or $b \bar{a} d a)$ daraja.

honoured, participial adj. ya$b a b b e$, fem. yababba, pl. ya babbu.

hoof, n. kofato, pl. kofatai.

hook, n. k̦ugiya, pl. kugiyoyi or kugiyuna; large wooden h. Kwandariya; hooks on a fishing-line, coll. mammari, murumuru; a fish h. fatsa, kugiyar fătsa.

hook, to h. on to kalgame (S.); to stick with a h. makăta. hoopoe, chigi da tukku, katutu. hop, to h. on one foot, intr. v. lange, bira, dira.

hope, n. bege, see expectation hope, intr. v. yin bege, ta maha, yin tamaha.

hopping, n. langa, lange. hopping, n. dire; a h. gam shillalo.

horn, n. kăăfo, pl. kafoni an kafuna, kaho; (a trumpet kăfo, waza; a cow with a ] growing downwards saniy 
mai-dauri; without horns dugŭmi.

hornbill (Bucorvus pylrhops), ground h. burtu; African h. chilikowa; shamo, shamuwa; see also ka-ki-ganin Allah.

horned, da kăfo.

hornet, n. rina, pl. rinoni, rinainai.

horse, n. doki, fem. godiya, pl. dawaki, dawakai; spec. young h. săfi, săfe, fem. săfiya; dukushi, fem. dukusa, pl. dukusai; old lean h. guzuma, guabta; war h. ingarma, pl. ingarmu; a h. that walks with its ankles on ground mai-takin biri; a h. with a hollow back doki mai-lotso; a bay h. furde, sari; a black h. akawali, kyara, kiyara; a speckled black and white h. chichiro; a brown h. aharas, aharashi, fem. aharasa; a creamcoloured h. akaza; a light brown h. gunya, sira (S.); a bay or dun h. sari; whitefaced h. bola; a white h. kili, fem. kiliya; a roan $\mathrm{h}$. bidi, dandas saki; a black and white h. kilikamya (S.), sheji; h. speckled white with black alshafi, fem. alshafa.

Horse's harness, diseases, etc. : small bells on $h$. head chikasaura, chikasabra; strap round h. head maraya; h. breast-band dan yăba; h. breast-strap fastened to saddle majayi; h. cloth put under saddle kafu; a disease of $h$. foot just above the hoof alafa; a skin disease in a h. siminya; a disease on legs of a h. tijo; a medicine poured into $\mathrm{h}$. mouth chushe; a place for horses shamăki, pl. shamăkai; a h. disease which causes the hair to fall off dasusu; a runner in front of a h. gurgure.

horseback, on, adv. phr. bisa (or bisan) doki; a man on h. mai-doki, pl. masu-doki; to mount on h. hau bisa doki; to take exercise on h. $k i$ lisa.

horse-fly, n. barbaje; also called damisan dawaki being spotted like a leopard; a large buzzing h. gwarje.

horseman, n. mai-doki, pl. masu-doki.

horse-raddish, tree (Moringa pterygosperma) zogalagandi. hospitality, to show h. yin bakonchi.

host, n., entertainer mai-măshidi, mai-masabki; a great multitude babban taro.

hot, adj. da zafi, dumi, da dumi, 
dimi, da dimi; h. water ruwan zafi or ruwan dumi; it is $h$. (of the weather) rana da dumi; the h. or dry season rani; the hottest part of the dry season just as the rains are beginning băzara; the $h$. month at end of rains agazari (K.), agajeri (S.).

hot-tempered, mai-jaji.

hound, n., see dog.

hour, sa' $a$; the hours of the day are only reckoned approximately by the Hausas, they are: jijifi the twilight just before the dawn; assuba or $a z u b a^{*}$ the dawn; hantsi two hours after dawn, i.e. circ. 8 a.m.; walaha circ. 10 a.m. ; rana tsăka or tsăkar rana mid-day; zawal circ. 2 p.m. ; azuhur, azahar, time of the call to prayer, circ. 2 or 2.30 p.m. ; la'asar 4 to 5 p.m.; magariba or magarub just before sunset; mareche late in the evening; almauru, lisha very late in the evening; dare time between lisha and jijifi. house, n. gřda, pl. grdaje, gidadaji, shigifa, pl. shigifu and shigifofi; a fourcornered thatched h. tafarfara, see hut; $h$. of one room daki, pl. dakuna; he is in the h. yana laka; top of $h$. or upper storey of $h$. kan daki; a desolate ruined h. kango, pl. kangogi, kangaye; all the people belonging to one h. kabila; master of h. mai-gĭda; a flat-roofed h. soro (K.), pl. soraye.

household, n. gr $d a$; father of the h. ubangida, fem. uwalğ̌da or uwarğ̌da.

householder, n. mai-gŭda. hovering, (of a bird) shavvāgi, jeua.

how, adv. 1. interrog. kaka.

2. rel. kaka, kanda, yaya (S.), wăda, yăda, yadda; h. dost thou know? kaka ne ka sani; h. are you going to manage? kaka za ka yi; h. long? har yaushe, tun yaushe; h. many? nawa or guda nawa; h. much? nawa; phr. h. many persons were there? mutum nawa ke nan? $\mathrm{h}$. long will it be before you finish? sai yaushe $z a k a$ gama?

however, 1. rel. adv. (in whatever manner) ko kaka.

2. adversative conj. (but) bari dai; fache*.

howl, intr. v. yin kuka, yin hargowa.

hucksters, yan shimfida, see retailer.

hue, n. (of colour) launi. 
hum, n. amo; h. of conversation lŭmi.

hum, intr. v. yin amo.

humanity, n. (the nature of man) mutumchi.

humble, adj. da karamin rai. humble person, ladăfi, ladăbi.

humble, tr. v. Kaskantad da, maidakarami, e.g. hehumbled himself ya maida kansa karami.

humiliate, to kankanta.

humiliation, n. kankanchi.

hump, n. doro, kazaza, kusumbi; h. on bull, etc. tozo; humped cattle jabajaba; without a h. muturu.

hump-backed, adj. mai-dloro, mai-gantsarwa, da kusumbi.

hunch-back, n. kazaza, kusumbi, mai-doro.

hundred, num. llari, miya, minya, zangu, the last is generally restricted to counting cowries; two h. lari biyu, metin*, metan*.

hunger, n. yunwa, yunwachi.

hunger, to suffer, n. matsu*, matsi, jin yunwa.

hungry, adj. da yunwa; I am h. ina da yunwa; a h. person mayunwachi, pl. mayunwata.

hunt, v. yin farauta. hunter, n. mafarauchi, pl. mafarauta.

hunting, n. farcuta.

hurry, n. garaje.

hurry, to be in a, v. gaugata, gagauta; h. up ku chăka, ku jı̌ka or ku yi da ǰ̌ka; I am in a h. na kosa.

hurt, tr. v. fama; I have h. my leg na fama kafa.

husband, n. miji or namiji, pl. maza, gwarzo*; h. and wife miji da mata.

husk, n. (of grain) surfe; a h. of maize totuwar masara.

husk, to h. grain, tr. v. surfe, surfa, swaba, saba, sabe.

husked, (rice, etc.) surfaffe. husks, coll. dusa, dussa (S.) ; h. from wheat, etc. tsăki; h. of guinea-corn kono (K.), konu (S.); h. enclosing an ear of corn buniya.

hut, n. shigifa; a h. for storing grain in shirayi; a light thatched h. rudu; a grass h. bukka, tsangaya; a h. with grass walls but with distinct roof dakin zana (K.), dauke, dabi (S.) ; a round h. kago; a mud h. kudandani, tseko ; a $h$. in a compound reserved for domestic work tsakakari*; a rectangular h. tafarfara.

hyena, kure*, fem. kura, pl. 
kuraye, amīna*, daguyau (K.), gazau*, shaki (S.), sheyaki (K.); striped h. sayaki, shaki, saki, sheyaki; young of h. barmakai.

hypocrisy, n. riya, pl. riyoyi; to practise h. yin riya.

hypocrite, n. mai-riya, pl. masu-riya.

hyrax, West African tree h. (squirrel) beran b̌sa.

I, lst pers. pron. comm. gender; 1. $n a$, prefixed to aor., e.g. I went na tafi; I saw him na gan shi; with $b a$, often contracted, e.g. I did not see him ban gan shi ba; see H. Gram. p. 9.

2. $n i$ suffixed to fut. and passives, e.g. I shall go $z a$ ni $\operatorname{taf} i$; I was wounded by a gunshot aka halbe ni da bindiga. As a prefix to a verb $n i$ expresses the fut., e.g. ni tafi I shall go; prefixed to the aor. it denotes an emphatic past, e.g. It was I who went or I indeed went $n i$ na tafi; $n i$ is also to be used in emphatic expressions, e.g. I myself ni da kaina; I alone ni kadai; is it I? do you mean me? niya.

3. ina expresses the present and should be followed by the participial form if there be such, thus, I am coming ina tafowa; but ina so I am willing.

ibis, rara, tuntumi; the African wood i. tsagagi; see stork. idiot, n. 1. from birth saruru*, shashasha*.

2. fig., see fool, foolish. idle, adj. 1. (doing nothing) lalafa; an idle person raggo, fem. ragguwa, pl: raggaye, raggaje, raggage, ragguna; dan karma, madudu (S.), bakurogi; one who is $\mathrm{i}$. mai-lalachi, malalachi, maikasala, bahili* ; to be i. yin hriji.

2. (in vain, unprofitable) banza, babu anfani. idleness, n. răgaita, pl.răgaitu, ragganchi, raggonchi, karma, lalachi, lalafanchi, sausauchi, sosoch $i$, the last also of unwillingness to work; to fight shy of work rāfashe aiki, ragaiche, yin huji.

idler, n., see idle.

idly, one who saunters about i., n. mai-ragaita.

idol, n. $t s \bar{a} f i$, pl. tsäfuna and tsafaffuka, gumki, gwumki, pl. gwumakai.

idolater, n. matsafi, pl. ma. tsafa.

idolatry, n. shirku, kafirchi. 
if, conj. idan, in, kădan (S.), kan, izan, da, e.g. if I had known, I would not have done it da na sani da ban yi shi ba; kan (before b, kam), kur*, kul*.

ignoble, adj. banza, na banza. ignorance, n. (i.e. religious ignorance) jahilchi.

ignorant, adj. (relig.) jahili. To be i. in a general sense must be expressed by means of the verbs sani, $j i$ or (in the case of an art or science) $s a b a$ with negatives.

ignorantly, da jahilchi. iguana, n. tsari, tsare, guza. ill, n. (nisfortune, loss) barna, hasā̄ra, as̄̄ra, tasari.

ill, adj. 1. (bad) mugu, fem. mugunya, pl. miyāgu, banza.

2. (sick) da chiwo; to be i. yin chiwo, jin chiwwo; he is i. shina da chiwo; to become i. chiutu, chutu. illegitimate, child, n. shege, dan shege, dan farka.

illiberal, adj. (stingy) da taurin zuchiya; he is i. hannunsa ya bushe or hannunsa busashshe ve lit. his hand is dry.

illiberality, n. taurin zuchiya, kalmashen zuchiya.

illicit, adj. haram.

illness, n. chiwo, chiwuta.

illuminate,tr.v.1.gen.haskaka.
2. to i. a manuscript $z a y a-$ $n a$.

image, n. 1. (likeness, picture) kăma, pl. kămānu, kămannu.

2. (a graven image or idol) gumki, gwamki, pl. gumakai.

imagination, wasuwasi* ; she imagined within herself $t a$ yi wasuwasi a zuchiya tata. imagine, v. yin tamaha, zato, yin zache; see suppose.

imbibe, tr. v. (to drink in or absorb) sha.

imitate, tr. v. to i. another's pronunciation or actions $k o k$ koya, rikida, e.g. I imitate him ina kokkoyonsa.

imitation, kokkoyo.

immediately, adv. ko yanzu, nan $d a$ nan.

immerse, tr. v. tsoma, nuche, mutse, niche, dulmiya, yin dunane.

immigrant, shigege. immorality, (between women) mädigo.

impasse, (a place from which there is no outlet) ky̆rewa. impatience, garaje. impatient, adj. maras-hankuri. impede, tr. v. hana. impediment, n. 1. hindrance abin hana.

2. impediment in speech ininar halslie. 
impertinence, tsiwa, janjanchi, giggiwa (K.), taurin ido. impertinent, adj. mai-tsiwa, matsiwachi.

importance, manyanchi, mayanchi.

important, adj. babba, pl. manya or maya; an i. person, n. datijo, kunkumi*.

impossible, it is, impers. v. ba shi yuuwa, ya gagara, ya faskare, ya gaza, ya kāsa; an i. task tarki* (S.). improper, adj. ba daidai improve, tr. v. gyarta. improve, in health, intr. v. warware, yin rangwame, jin dama; see health.

improvement, e.g. in health dama.

impudent, adj., see impertinent.

impurity, of water zartse. in, prep. chǐkin or dăga chǐkin, a, gun, e.g. in the basket chikin sanfo; in this place a wurin nan.

in order that, conj. phr. a bisa, domin, don, e.g. practise diligently in order that you may shoot well ku yi anniya har da za ka iya halbin bindiga da kyau, in order that he might hear domin or don shi $j i$.

inability, n. gajewa. inasmuch, i. as da shi ke or da ya ke.

incantation, tsubbu, dăbo. incense, n. turare, kamshi*. incessant, madawami, fem. madawamiya.

incline, a steep, n. gangare or gangara, pl. gangaru.

incline, tr. v., to $i$. the head tsugunna; to i. the ear karkata kunne.

incomplete, to be yin kwabro. incompletely, to do a thing $\mathrm{i}$. saya.

incompleteness,

kwabro, kwauro.

incorrigibility, shakiyanchi. incorrigible, shakiya.

increase, n. dăduwa, auki, abki, kāri, karuwa.

increase, v. 1. tr. k̦āra ; dăda, dădi, yin auki (or abki), dora, săfa, sŭfa, riba, shirga.

2. intr. dăda, yin dăduwa, yado, yadu, kāaru, gawurta, gawusta, taska, zarche*.

incredulity, an interj. expressing i. aya! haba! hubba! incurable, e.g. an i. disease chiwon wofi; the fool is $\mathrm{i}$. mahaukachi ba shi warkewa. indebted to, intr. v., e.g. I am indebted to you ina $d a$ bashinka.

indecency, n. kazamta, shăkiyanchi. 
indecent, adj. l̦azāmi, pl. kazāmai, maras-kumya, babu kumya, shăkiyi.

indecision, zara.

indecorous, adj. ba daidai. indeed, 1. adv. (in truth, in fact) hakika, babu shakka or babu shak, babu waua, da yaskiya, takar (K.).

2. as affirnative emphatic particle $a i$, ashe, aiua or ewa, anche, mädala, dai or de, the last is enclitic following the word which it is desired to emphasise.

3 . interj. of doubt or surprise to! ashe! anche! haba! Thus, in question and answer, indeed? indeed! ashe? ashe! da gaskiya? da gaskiya! indemnification, ramko. indemnify, to ramka. independence, zăman kansa. india-rubber, n., see rubber. indicate, v. nuna, nuni, gaya. indifference, n. (carelessness) lalachi.

indigence, n. talauchi. indigenous, kado, pl. habe. indigent, adj. talaka, talakka (S.), pl. talakawa, talakkawa ; an i. person mai-talaka. indigo, n. $b \bar{a} b a$, shuni, talaki*; spec. the second annual crop of i. kususu; an indigo dye-pit marina, pl. marinai; old used-up i. dagwalo, dagalo.

indistinct, to become, intr. v. dushi.

indistinctness, n. dushewa. industrious, n. maaikachi. infant, n. (up to one year old) jinjiri, pl. jirajirai, jarīi, jarīli.

infantry, coll. n. kirma; infantry leader sarikin kirma. infidel, n. kafiri, pl. kafirai and kafiraua.

infidelity, n. (in a religious sense) kafirchi.

infirm, adj. kumāma, see weak.

infirmity, n. kumamanchi.

inflict, tr. v., to i. blows buga, bubbuga; see beat; to i. punishment pallashe, fallashe. influence, n. (authority, power) hukumchi.

inform, v. (to bring intelligence, to apprize) labarta, ba labāri, sanan da, sanas da, sanar da, sanashe; to i. against sare, sara or zara* ; see accuse.

information, n. (news, account) labāri.

informer, n. mai-sara, pl. masu-sara.

ingrate, n. butulu, mai-butulchi, pl. masu-butulchi.

ingratitude, n. butulchi. 
inhabitant, n. mai-zamna, pl. form mazowa.

inherit, v. gāda, gāade, gāado, gā $\ddot{j}$, gāje.

inheritance, n. $g \bar{a} d o$. inheriting, gadowa.

inheritor, magaji, pl. magada. iniquity, n. mugunta, leta ; see evil.

injure, tr. v. (to damage) băta, bāchi, barnatadda.

ink, n. taddawa, adawa, tawa$d a$ (K.) ; a tree from the fruit of which i. is made fara-kaya; a gum which is put in i. kāro; a powder used in making i. kawiya, kunkuniya*.

ink-blot, n. dangole.

inn, n. (i.e. a khan or halting place for the night) mashidi. innkeeper, n. mai-mashidi. innocent, adj. babu laifi, bara;

an i. person maras-laifi; to be declared i. kubuta. innuendo, karin-magăna. innumerable, adj. expr. by phr. $f i$ kidayawa, e.g. he has innumerable books shina da litatafi sun fi kidayawa. inquire, v. tambaya, yin tambaya, yin binchřke.

inquiry, n. tambaya, sha-loga (K.), binchike, bahasi, bahatsi*.

insane, adj., see mad. insanity, tabuwa.

insect, n., spec. minute i. found in kola-nuts sankara; a night-flying i. which has a bad smell buzuzu ; a boring i. gunda, gumda; see beetle. inside, n. chǐki; i. the house chı̌kin ǧ̌da; its inside or inside it may both be expressed by chǐkinsa; see in. insight, n. (clear perception) lura.

insipid, adj. lāmi, da lāmi, babu zaki.

insolence, gigiwa (K.), janjanchi, tsiwa.

insolent, adj. mai-tsiwa, da tsiwa, matsiwachi.

inspire, v. (to breathe in) tofo. instance, n. nüni; see example.

instantly, adv. nan da nan, koyanzu.

instead of, prep. gurbin, wurin, bigeri, madadin, e.g. instead of it gurbinsa, gun$s a^{*}$, wurinsa, bigerensa.

instigate, to chuna. instruct, v. 1. (teach) koya, e.g. instruct me in reading ka koya ma ni karatu; galgade, gargadi.

2. (of religious instruction especially that combining reproof and threatening) fora, fori, fore, yin foro. 
instruction, n. foro, wa'azi*, wa'azu*, alāma or halāma, pl. alamomi, almajirchi ; all these words refer to religious teaching, $i$. in a general sense must be expr. by verbs etc., e.g. a man of no i. wanda bai san komi ba; he received much i. from them in literature suka koya masa karatu dayawa ; self-i. haye*.

instrument, n. 1. (implement) kaya, pl. kayayeki, makami.

2. (musical i.) kidi or kida, any kind of wind i. busa, pl. bushe-bushe; spec. a kind of stringed i. machirkiya, matsirkiya; a wind i. pampami, famfami; wind i., flute sarewa; wind i. resembling bagpipes algaita or algaitu; a player on a musical i. makidi; see music.

insubordination, tаyаsиua, kin $j i$, kangara.

insufficient, to be yin kwabro. integrity, n. (honesty) gaskiya. intelligence, n. 1. (mental power), tsimi, hasikanchi, wayo, fasaha*; see understanding.

2. (news) labāri, e.g. let me give you i. of the war im ba ka labārin yaki.

intelligent, adj. gwani, maitsĭmi, da tsimi, hasiki. intend, v. for the idiomatic use of $d a$ to express unfulfilled intention see Gr. pp. 34,46 , e.g. I intended to go da za ni tafiya, had I known I would not have thrown her down on purpose da na sani da ba na jefa ta da gangan ba. intention, n. (purpose) kŭli, ganganchi; (fixedapplication) anniya, alāma; see prec.

intentionally, adv. da gangan. intercede, to i. for cheta, chetas.

interceder, mai-chechi.

interceding, fafo.

intercession, machechiya.

interest, on money ruwa, fifiko, riba.

interfere, v. shŭga shăgali, yin karambani.

interference, n. gadauniya, janjanchi, shishigi*; i. with what does not concern one karambāni, kazallaha, izgili, isgili.

interior, n. (the inside of anything) chiki.

interloper, shigege.

intermarry, to garwaye. intermingle, tr. v. hautsina ; intr. v. saje (K.), sade (S.). intermingling, surki, see mixing.

interpret, v. 1. (to translate) juya da magana or juya 
magana, yin fasara, fasarta, mayas $d a$; he interprets $y a$ rabbi fasalinsa.

2. (to explain) waye.

interpretation, $n$. (both translation and explanation) $f a-$ sara, fasali*, wayewa.

interpreter, n. alfăkani, $t a-$ furta, mayayi*.

interrogative. This sense is expr. by a change in the intonation, by $k o$ placed at the beginning or end or at both beginning and end of a clause, or by adding the phr. $k o$ ba haka $b a$ ? also by $b a$ when answer is in affirmative, $n i b a$ ? It is $\mathrm{I}$, is it not?

interrupt, to i. yin shishige, tura magana; a nickname for one who interrupts a conversation kazallātuwa.

interruption, n. fäshi. intersection, gichi, gichiya. intertwine, to kalgame, kargame.

intervals, at i. wuche-wuche. intestine, n. spec. the large $i$. tumburḳma, tuburḳma, karera, mazawuri; the intestines coll. hanji.

into, prep. chikin or dăga chikin, e.g. he fell i. the water ya fadi chikin ruwa; he was turned or changed i. a sheep ya sauya tumkiya. intoxicant, n., an i. drink barasa, this word is also applied specially to gin; an intoxicating drink which is made from the palm tree (tukuruwa) bammi, bam; an intoxicating drink made from guinea-corn giya ; an i. drink made with honey, salt and water buza; a place of intoxicating drinks mashaya. intoxicated, maye. intoxication, n. maita. introduction, a letter of, $n$. bishara.

invalid, machuchi, majiyachi, majinyachi.

invasion, farmaki, falmaki, firmaki.

invent, to kaga.

invention, lage (S.).

investigation, judicial bahasi, binchike.

invisibility, (the power to vanish at will) baduhu, $b a$ dufu.

invocation, n., i.e. to God zikiri, safirchi, safurchi; we make i. muna zikri. invoke, to $s \bar{a} b a, s \bar{a} b i$. invulnerable, dan tauri. iron, n. karife, karfe, pl. karafa, k̦arfaifai, karfuna; spec. i. wrought into cups, bright i. zubi; to burn with hot

i. lalas; an i. for brand- 
ing zarto; an i. pot karife, karipe.

iron, adj. na karife, fem. ta karife, with plurals na karife, e.g. i. bars sanduna na karife. iron ore, n. tăma, matamachi; i. dross kashin tăma.

irons, leg-, n. gigar, malua. irony, gătse.

irregular, of i. lengths sabe. irrigate, to shayas da. irrigated, garden, n. lambu. irritable, adj. da zafin rai. irritated, particip. adj. husanche*.

irritation, takaichi, see anger. is, subst. v. 1. (simple copula) with masc. subject ne, with fem. che, with either ke.

2. (implying real existence = there is) akwai; ina, na, fem. $t a$, thus, there is ina $d a$ shi, there are many ina $d a$ su dayawa; ke with nan, e.g. there is a book which I know wani litafi ke nan da na sani; see be.

island, n.gungu*,pl.gunguna*, lungu*, chibiri*, tsibiri*.

isolate, tr. v. yin kadaita.

it, pers. pron. neut. $y a$, fem. $t a$; separate and emphatic forms shi, fem. ita; its -nshi, -nsa, fem. -rsa; nasa or nai, fem. $t a s a$, tas or tai.

itch, n. ḳaiḳai, ḳaikayi, kaswa, kazuwa, susa, zuza, kurji; one who has the i. mai-kurji. itch, to yin susa or yir zuza. itching, n., spec. i. sore on toes or fingers kurkushe, kusakushi, kushekusheya; a prickly plant that causes i. karara. ivory, n. hakorin giwa or haurin giwa; a piece of $i$. haurin giwa, kăkara*.

jackal, n. dila, pl. diloli, malamin dăwa, kărem buki, karem biki, dan ba'ura, ballo; the cry of the j. kyakkyewa, kekewa.

jail, n. kurkuku, see prison. jailer, mariķo.

jam, tr. v. (to press) mache, machi or matse; (to stick fast) $t \bar{k} k a \breve{r} a^{*}$.

jar, small, n. sintali, shintali, tulu*.

jaw, n. kumatu, kumche (S.) ; fig. jaws baki.

jaw-bone, mummuke, pl. mukamukai.

jealous, to be kisanta. jealousy, n. kishi or kishiya, pl. kishiyoyi, hăsada, shamata.

jeer at, v. $b a^{\prime} a$ or yin ba'a, yin gori, rena,kwalla*; ba dariya, e.g. they jeered at us suka ba mu dariya. jelly-fish, n. Kawara. 
Jerusalem, pr. n. birnin ḳŭdus. jester, n. (buffoon) babambade, bade, maba'achi; (foolish trifler) wawa.

jesting, n. bananchi, annashuwa.

Jesus, Isa, Yasu'u, the latter form represents the original Arabic name.

jet-black, adj. baḳi kirin.

Jew, gent. n. ba-Yahude, pl. Yahudawa.

jewel,n.yakutu*; ${ }^{*}$ utsi*(stone) oftendenotes a precious stone. jog, e.g. of a donkey sassaka, see trot.

join, tr. v. găma, gwarmi*, rika, lika; to $\mathrm{j}$. heads together (in consultation or forming a plan) gama kai; intr. (to fall in with anyone by overtaking or meeting him) gamu or gamo constr. with prep. da; tarda, tarad $d a$ and taras $d a$, e.g. we joined him mun gamu da shi or mun taras da shi; to $\mathrm{j}$. issue Kulla*; to be joined together kullu.

joiner, n. (carpenter) masassaki, pl. masassaka.

joint, n. ido*, pl. idanu*, idandanu*, idanuwa; ankle $\mathrm{j}$. idon sawu, idon kafa; wrist j. idon hannu (also = knuckle); godawa*; j.of scissorskwarmi, pl. kwarmu, gwarmi; to be out of $\mathrm{j}$. gochi and goche; j. of the body găba, pl. gabobọi; to suffer from a disease in the $\mathrm{j}$. targade.

jostle, tr. v. tunkuda, ture.

journey, n. tafiya, pl. tafifiya;

provisions for a j. guzuri; to make provision for $\mathrm{a} \mathrm{j}$. yin guzuri.

journeying, n. tafiyawa.

joy, n. (the inward feeling) farin chiki; (coupled with the outward expression) murna, bushasha, bashasha, fara'a; to experience j. (to rejoice) yin fara'a, yin or jin murna; a cause for j. abin murna; j. or a cry of $\mathrm{j}$. guda ; to cause j. bada murna.

judge, n. alkāali, pl. alkālai, alkallai (S.); the office of a j. alkalanchi.

judge, v. 1. gen. (to look into, discern) yin bibiya; in a weaker sense, to imagine, or think tammaha or yin tammaha.

2. (of a judge) yin shari'a, $k \bar{a} d a$, yin alkalarchi. judgment, n. 1. gen. bibiya.

2. (of law and justice) shari'a, hakumchi or hukumchi,fukumchi*, alhaki, hisabi; the $\mathrm{j}$. day ranan (or ran) 
gobe (lit. the day of tomorrow), gobe ; j. seat karaga. jug, n. tulu*, randa*; a brass j. with narrow neck shintali, shantali; see jar.

juggling, dăbo.

juicy, mai-mai.

juju house, (in a pagan village) gidan dodo.

jujube-tree, magariya.

jump, n., of a fish or frog, bulma, burma; he gave a j. ya yi wuf.

jump, intr. v. tuma; ďra, dǐri, dǐro, dara, daro ; tsalle, tsuili, tsallache; to j. backwards and forwards wura; to j. down gangara, tsirga, tsirgo ; to $\mathrm{j}$. over haura.

jumping, n. dire, tsalle, tuma, tumi.

just, adj. da gaskiya, daidai; of things (=lawful) halal; a j. man mutumen gaske (gaskiya) or mutum na gaskiya.

just, adv., as in expression j. (now) ko (yanzu).

justice, n. 1. (administration of the law) shari'a.

2. (moral right) addilchi. justify, tr. v. 1. (to prove to be in the right, to vindicate as true) gaskanta.

2. (of a judge etc. to declare in the right, to ascriberight to)bada gaskiya,

R. H. D. he was justified am $b a$ shi gaskiya.

jute, malafiya,lalu,turgunuwa; bastard j. rama.

Kano, Kano the chief commercial town of the $\mathrm{W}$. Sudan.

keen, adj. 1. (sharp-edged) $d a$ kaifi.

2. (of acute intelligence) mai-lura, mai-wayo.

keep, n. (to retain, hold) rike, rika or riki; (to tend, e.g. sheep or cattle) kiwo; to $\mathrm{k}$. carefully kiyaye; to k. a promise chika magana, kama magana; to k. on doing anything rika.

kerchief, n. maharma; a woman's k. kallabi, alfuta.

kernel, n. ǩwära, kwaya.

kettle, n. shintali, sintali or shantali, pl. shintalai; an earthen k. karife* or $k a$ ripe*.

key, n. makubli, makulli, mabüdi, dan makubli.

kick, n. shuri.

kick, tr. v. shura, shure or jure*, bangaje, habri or harbi used of horses ; to k. forwards mangara; to k. away hanbare, hambare.

kicking, n., e.g. of a donkey butsări. 
kid, n. dan akwiya, pl. yan (or yayan) akwiya.

kidney, n. gidibi (S.), kidibi, pl. gidibai, kidiba; k.oda, kwoda.

kill, v. kăshe, kăsa, kǔsa, with a shortened form kas, kibe, fauchi*; he was killed outright aka yi masa take.

killing, adj. (murderous) kăsau, kăso.

kilt, cf. a man with a k. of grass mai-bunu a gindi.

kind, n. iri, pl. irare, launi*.

kindle, tr. and intr. toyi, towi, toya, toye, tuya, tuna ; to rekindle or blow up a fire which is nearly out fura, intr. furu, e.g. they re-kindled the fire suka fura wuta, the fire was re-kindled wuta ta furu; dosana, hasa, haza, tr. he kindled the fire ya hasa wuta. kindness, n. (goodness of heart) nagarta; (favour, benevolence) alhèri, chiki daya, gafara and gafarta, nï̈ma, nema, hasali (S.); an act of k. kyauta, aikin gafara, jinkai; to do an act of k. yin alherri, yin kyau, e.g. they did me an act of k. sun yi ma ni kyau.

kindred, n. kabila*, dangi, danga or dagi*, pl. dangogi. king, n. sarki or sariki, pl. sarakuna or sarakai, sarāki, sultan*; a king's son yarima, gimba, pl. gimbayi; daughter of a k. gimbiya; epithet applied to a k. dan furdi; a reigning k. sariki mai-chi; a deposed k. fitachen sariki. kingdom, n. sarauta, sarota, daula; to gain possession of a k. chin sarauta; see accede.

kingfisher, pied k. chinoya, chinuya; African belted $\mathrm{k}$. machi tsundum; blue $\mathrm{k}$. tsitar or tsintar.

kiss, n. sumba.

kiss, tr. v. tsotsa, sumbunta, sumbunche; to $\mathrm{k}$. hands to yin sumba.

kissing, tsotso.

kitchen, n. madafi, pl. mada fai, wurin dăfuwa.

kite, n. (the bird) shafo, shaho, kōlo, shirwa.

knead, to k. together, tr. v. garwaya.

knee, n. gwiwa, pl. gwiwaye, gwiwoyi, gwiwu, guwawu; pushing with the k. gurla. kneel, intr. v. durkǔsa ; kneeling dulkŭshi, durḳ̌̆shi; to k. down or prostrate oneself gurfana (S.).

knickerbockers, dan wando. knife, n. wuka, pl. wukake, wukaikai (usually with two 
edges); barho(with one edge); mayanki; to sharpen or whet a k. gyarta (or wasa) wuka, yuka (Zanf.); spec. a small k. almōsa; a k. used by women kududuri; a kind of $\mathrm{k}$. with handle to fit wrist and blade projecting backwards kangar or kanga; a k. carried up the sleeve, attached by a leathern ring wukar hannu; a scoop-shaped k. mafitsara; a sort of missile k. gāriyo, q.v. ; handle of a k. bota, kota (K.) ; see kijigi.

knit, v. sharaba*.

knock, v. gen. buga; to k. against, intr. gochi, goche, gwabche, kăbra, kafra, tr. as the hand against a wall gwabra, gwabre, gwabure, gwabri, gumbari; to k., e.g. with a stick zungura; to $\mathrm{k}$. or kick bangaje; to $\mathrm{k}$. at a door buga leffa, kwankwwasa; to k. down tankade, bige (K.), kirme (K.), kilme (S.).

snot, n. kulli, pl. kullai, kulloli; a k. made in thread to prevent the strands from unravelling hanchi; to tie in a k. kumbuche; to get into a k. sarke. now, v. sări, shĭna, rabe da; to k. clearly shaidani, fahim$t a^{*}$; to $\mathrm{k}$. and understand well sansanche; to $\mathrm{k}$. certainly tabbache, tabbata, e.g. do you $\mathrm{k}$. for certain ? ka tabbata? had you known? da kun sani? it cannot be known $b a$ ta sanwwa.

knowledge, n. azanchi, lura, shini, shǐna, săni.

known, to make, v. ambachi, gaya, chashe.

knuckle, n. gwiwar yatsa, idon hannu.

kola-nut, n. goro, pl. gwarra ; gamagari; spec. a variety of k.-n. from Gwanja ataras, from Yoruba $i b i$; a lightcoloured k.-n. ganjigaga; see also labuje, gamagari, ibi, kursan-goro, gazari, sandalu, hannun ruwa; a bad k.-n. gobro* ; a large k.-n. goriya; packing placed round k.-nuts fufu, huhu; an insect found in the k.-n. sankara; a basket of palm fronds in which k.-nuts are packed makara, mankara; a late crop of k.-nuts jankarago; large selected k.-nuts marsa; large and small k.-nuts mixed saranwaga; little k.-nuts minu; an early crop of $k$.nuts nata.

koran, n. kuran, alkorani, alkorani; the all-night reading of the k. tǔkuri; saying the k. by rote tulawa*. 
labour, n. aiki, pl. ayuyuka, ayuka, aikoki or aikuna; farm 1. aikin gona; l. pains wahalar haifuwa, nakudar haifuwa.

labour, v. yin aiki; aiki.

labourer, n. maaiki, fem. maaikiya, pl. masu-aiki, maaikachi, maaikata ; ǩwadigo, dan kwadigo.

lack, n. rashi.

lack, tr. v. tabe, tafe, rasa, $k \bar{a} s a$, tozarta* $^{*}$; they l. money suna da rashin kurdi, see seq. lacking, adj. mai-rashi, by prefixing mara, e.g. l. sense mara-hankali.

lad, n. yaro, pl. yara.

ladder, n. mahayi*, ķarangama, kuranga (K.), kwaranga (S.), uusaranga (S.), tsani, matakara, matakala.

laden, participial adj. labche or labtache.

Lagos, the town of $I k o$.

lair, makwanchi.

lake, n. $\operatorname{kogi*} i^{*}$ pl. koguna, kogina or kogai, korama*.

lamb, n. dan tumkiya, pl. yan tumkiya; the paschal 1 . ragon lahiya.

lame, adj. gurgu, fem. gurguwa, pl. gurāgu, gurmu (S.), mai-gwanıi, pl. masugwami, amurgude, makasari, fem. makasariya. lame, to be, intr. v. yin gurgunta, dangyasa, dungashi, targade*; he goes 1. yana takwashi or tarkoshi; to make l. gugurta.

lameness, n. gurgunchi, gurugunta, gurmunta, gwami, takwashi, tarkoshi, dangyashi, dungashi, dingishi, k̦age*.

lament, v. yin kuka, see seq.

lamentation, n. kuka, pl. kokekoke; l. at a funeral makōki; to make 1. takaba; see cry.

lamp, n. fitila, pl. fitilu, fitilai or fitiloli; 1. oil man fiťla; he lit the 1. ya kunna fitila; we are working by 1 . light muna yin aikin fitǔla; 1 . wick lagwani.

lance, n. mashi, pl. masusuka or masu.

land, n. (phys.) kaăsa, pl. ḳăsashe, ḳasaisai; (country) kaăsa and gari, pl. garuruwa, garuruka or garigari.

landing place, n. mafichi.

landlord, hākimi*.

landslip, matusge*.

language, n. 1. (speech) $m a$. gana.

2. (tongue of particular nation) yare, magana; to speak the Hausa 1. yin ma gana Hausa; halshe, harshe pl. halshina or halassa hausa*, pl. harata* ; the? 
have no l. but Hausa $b a s u$ da yare sai Hausa.

3. (literary expression) karatu.

lapwing, see plover.

large, adj. babba, pl. manya, girma; a l. book babban litafi or litafi babba; very l. bankami.

large, to become, intr. v. girma and yin girma.

larynx, rakumin wuya.

lasciviousness, kwartonchi.

lasso, to zarge.

last, the, $n$. (final state or case) makarshe, makari, makare, makara; karshe used adverbially $=$ at the last, at last.

last, adj. na-baya, fem. ta-baya; phr. the l. day ranan (or ran) gobe, gobe; the l. sleep (death) makarin barchi; 1 . night jiya da dare; l. month watan jiya ; l. year bara; at 1. adv. yauyau, karshe.

last, to, intr. v. dăda, dădi, see continue.

lasting, n. (state of continuance) dădawa.

lasting, adj. matabbata*, madawami; long 1. madawami, fem. madawamiya.

latchet, maballi.

late evening, $n$. of time $m a$ garub or magariba, mangariba; later evening lisha. late, to be, v. jinkirta, nawa, yin nawa, yin yauchi, e.g. he was 1 . in arriving ya yi yauchin zakuwa; to be 1 . in doing anything makăra; one who is l. mai-makăra.

lateness, n. makăra, nawa; (delay) yauchi.

laths, thin wooden, coll. $k a-$ tamba*, kwangi.

latrine, makewayi, shadda. laud, tr. v. yin kirari, yin yabo also with pres. form $n a$, e.g. I laud thee ina yabonka. laudation, n. kirari, yabo; see praise.

laugh, intr. v. yin dariya; to cause to l. $b a$ (or bada) dariya, e.g. ya ba ni dariya he made me l. ; to $\mathrm{l}$. at zunda, yin zunda, yin zumda (S.), dāra, e.g. they laughed at me sun darani; he laughed at him yai gătse ga shi; to l. heartily keta da dariya.

laughter, n. dariya.

law, n. gen. shari'a, haddi*, umarni; to decide in 1 . raba shari'a; (religious ordinance) sunna, kaida; a prohibitory l. doka*.

lawful, adj. halal, halas; to be 1. halalta, halatta, halasta. lay, tr. v. $s a$; of a bird, to l. eggs aje (jefa, saka or yi) $k w a i$; to $\mathrm{l}$. aside $s a$; to $\mathrm{l}$. 
down kwantad $d a$; to l. hold of or on kama; to l. down, e.g. a load sabkad da.

laziness, n. raggonchi, ragaita, kiwuya, kuya, lalafanchi.

lazy, adj. lalafa, (idle) raggo, kumāma, mai-raggo, mairagaita, mai-son jǐki, magajiyi, shallali.

lead, v. bida, bishe.

lead, n. (the metal) dalma, darma; l. for making bullets harsasshe.

leader, n. babba, tunari*, koranga (K.), also $u b a, \mathrm{pl}$. ubanne and ubanai, e.g. their 1. babbansu; 1. of a fight uban yaki; spec. 1. of infantry sarikin karma; l. of caravan (chief) jaji; (the headman who precedes it) jāgăba or shugăba; (the man who walks behind it) madugu, pl. madugawa; l. in prayer liman, limami, pl. limammai. leaf, n. (of tree) tofo, toho*, pl. tofuna, waraka*, ganye, ganya, pl. ganyaye, danyen itache; 1. of a book warka, waraka; spec. a l. used for thatching fitta.

league, n. (alliance) găya.

leak, n. darshi, kăfa, yoyo; to stop a 1. toshe.

leak, intr. v. darsa, tarāra, tarāro, yin darshi, yin kăfa, tsiyaya, yoya, yin yoyo, zuba, $z u b o$.

lean, adj. ramamme, fem. ramammiya, pl. ramammu, guzuma, lange-lange.

lean, to be or become, v. rame, yin rama.

lean, intr. v., l. against jingina, jingine, dangana* ${ }^{*}, r \bar{b} b$, e.g. the fence against which he was leaning dangan da ya rābo da shi; to 1 . upon dangana, dogara, the last also fig. to l. upon in trust or confidence, e.g. we l. on thee mun dogare ka.

leanness, n. rama, ramuwa, ramanchi (K.), ramantaka (S.), alala.

leap, intr. v. tuma, dira, diro, diri, yin zariya.

leaping, n. zariya.

learn, v. koya, yin koyo, sanas; to l. by heart samu harda. learned, adj. mai-karatu ; a 1. man măsani, pl. măsana; malami, pl. mallamai; a 1 . woman malama*.

learner, a bami, makoyi, sabon shr̆ga.

learning, n. koyo.

leather, n. (after it has been tanned) kirgi; (before it has been tanned) fata; spec. strips of 1. coll. gunda; strips of black l. coll. kwaro; a 
scraper used in dressing 1. kartaje.

leather-dresser, n. majemi, pl. majema; baduku, pl. dukawa, badukai.

leathern, case for book, n. gafaka, gafakka (S.).

leave, tr.v.bari, bar, raida (S.); to l. a thing and come back baro; to leave a path or track sau (or sake) hanya; to 1 . behind bari or bar, raga; to 1. off daina, dena.

leaven, n. yami, kullu; spec. 1. made from the acid pulp of the tamarind tsamiya.

leaves, coll. kŭnnen itache, ganyen itache, sansāmi, sansāmin itache.

leech, n. matsatsaku, turgŭni (S.), tsatseku (Zanf.), chacheku, chichekko.

left, 1. (remaining, remainder, rest) saura, kingi, e.g. there is little 1. sauran kadare ya rage; food l. over sudi.

2. (of position) the 1. hauni, hagu or hagum; the 1 . hand hannu na hauni; 1.-handed bahago.

left, part. bararre, fem. bararra, pl. bararru; what is $1 . ? m i$ ya răge?

leg, n. kă̆fa, pl. kafafu, kafafuwa, kafafe, kăafofi, chinya, pl. chirryoyi ; l. bone kwabrin kăfa ; calf of the 1. dambubu, tukatukai(K.), sharāba ; bent 1. (a disease) gwami; l. bent by disease gwami, kaye* ; with bent legs (i.e. through disease) gurgu, fem.gurguwa, pl. guragu, this also = without legs.

legend, tariyo*

leg-irons, n. malwa, gīgar.

leisure, sukuni (S.), see opportunity.

lemon, n. lemu, lemo.

lemur, a species of (Potto) beran busa*.

lend, v. bada ăro, ramta; see loan.

length, n. 1. (of space and time) tsawa, tsawo, tsayi, tsai; tsawanta, matsawa, tsatstsawo.

2. (long continuance), of life yawan rai, tsawon rai. lengthen, to tsawaita.

leopard, n. dam̌̌sa, pl. dam̌́sai, argini*, tsawarwara*; hunting 1 . (or cheetah) rabbi. leper, n. kŭturu, pl. kutare, mai-kuturta*, mai-kuturchi*. leprosy, n. kuturchi, kuturta; spec. a mutilating form of 1 . machiri; white l. albaras.

less, adv. 1. (= minus in computing) bus, gaira, e.g. metin goma bus or metin yaira goma $=200-10$, i.e. 190 . 
2. (= English negative suffix -less) maras- (used as prefix), e.g. shameless maraskumya.

less, much l., comp. adv. balē, balanta, balante, barshe, e.g. this man was not able to walk, much less take up his load wannan ba ya iya yin tafiya bale shi dauke kayan$s a$.

less, to grow or make 1., see seq.

lessen, v. tr. and intr. răgi or răge, tawaya, towi, tauye ; intr. ragu, tawaya, tauwi, kasad $d a$; the waters are lessening ruwaye suna ragu$w a$; see seq.

lessening, participial n. raguwa.

lest, conj. (for fear that, that... not) $k \breve{a} d a$, e.g. he took the medicine lest he should die ya hadiye magani kăda shi mutu; don kăda.

let, tr. v. (allow) bari, bar; to 1. alone bari, bar, kyale* ; to 1. go shǐka; to l. down sabka, sabki or sauka, also (with da) sabkas or sapkas, shida, e.g. I l. down the load na sabke kaya or na sabkas da kaya or na shida da kaya; particip., l. down sabkakke; to 1. go sallame, săka, săke, săki ; to l. loose saki, kunche, kwanche, banya, banye; to 1. out (of hire, etc.) sufuri, sufurchi, yin sufuri or yin sufurchi; the particle in or im before a following $b$ is sometimes elliptically used to express 1., e.g. l. me follow you im bi $k a$.

letter, n. 1. (epistle) watika, wasika, wasichi*, pl. watiku, wasiku; takarda, pl. takardu, laya*.

2. (a sign of the alphabet) harafi, harifi, pl. haruffa.

lettuce, n., spec. water 1 . kainuwa.

level, adj. and adv. sosai, tangam, tangas; it is 1. ya yi sosai, ya bazu.

level, to, e.g. a road baji, baje; to rub smooth darje; levelled bazu.

liar, n. makariyachi, fem. ma kariyachiya, pl. makariyata. liberality, n. baiwa.

liberate, tr. v. yanchi, yantas, see free.

liberation, from slavery, $n$. diyauchi or diyanchi.

liberty, n. yanchi.

lice, coll. kwalkwata, kwarkwata, see louse.

lichen, n. toto (S.), tautau (K.). lick, or lick up, v, läsa, lashe, suda; to l. the hand tanda. 
licking, tandewa; l. of fingers, etc. tsotso.

lie, intr. v., to l. down kwanche; to 1. down to sleep kwana and kwanta; to l. face downwards rubda cȟ̌ki; a place to 1. down makwanchi; to 1 . in wait yin fako; a place to 1 . in wait mafaka; to 1 . with gǔfa (S.).

lie, n. kariya, kēri.

lie, intr. v. (to tell lies) yanke kariya, yin kèri; to give the 1. to kariyata.

life, n. rai, pl. rayu or rayŭka, rayukka, rawuka; in more general sense (= Engl. time) zamani, yayi, e.g. during the 1. (= in the time) of the prophet zamanin annabi; to come or come back to l. rayu; coming back to l., participial n. rayuwa; to restore to 1 . raya; position in 1. mutumchi; a l.-time kwakwaro; 1.long matseyi.

lift up, tr. v. chira, chire, chiro or tsira, tsire, tsiro, täda, tashe, tsaida, hauda, haushi, hausa, daukaka, do$k a k a$; spec. to l. up a heavy weight sunguma.

light, adj. (not heavy) shakap, sakwap, săkai, sakat.

light, adj. (full of light) maihuske; l. coloured patsi. light, n. haske, pl. haskoki, haskaikai; see seq.

light, tr. v. 1. (to give light) haskaka, bada haske, e.g. the moon gives light wata shina bada haske.

2. (to set alight) to 1. a

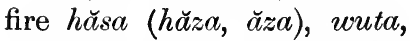
füra (or hüra) wuta, yāda wuta, dosana, kŭna, kunna; the fire is lit wuta ta furu; to l. a lamp kunna fitila.

light upon, intr. v. tsaya.

lighten, tr. v. 1. (to illuminate) haskaka*, sarasara.

2. (of lightning) yin walkiya.

lighting, (of a fire, etc.) yãdiya . lightning, n. walkiya.

like, adv. tamka, tamkar, tamkan, tamkat, tankat, tanfari, kăma, kakakat*, kăman or kămal, e.g. this is 1. that wannan shi ne tamkat wanchan; ya, yi, ta'ada*; adj. tanfari or tamfari; the following are substantival (as in Engl. one's l.) kama, pl. kamannu, e.g. his l. kamansa, misalinsa; see likeness; what is l. to something mai-maki, wani, e.g. 1. him waninsa, shr̆ge, e.g. l. them shĭgensu, kwatanchi, e.g. 1. this kwatarchin haka, misali, see seq. 
like, adj. mai-kăma ; it is more 1. this than that ya yi kăma da wannan ya fi wanchan.

like, as, adv. tamkar $d a$ or tankar da, kăma or kămad da and kăman da, misali*, awa, kamar yadda; 1 . this kwatanchin hăka.

like, to make, tr. v. daidaita; pass. it is made l. unto a kwatanchi; to be l., i.e. to resemble yin daidaiche, yin kăma da.

like, tr. v. so, marmari.

liken to, tr. v. kwatanchi, kwatamchi (S.), ḳădara, kudira.

likeness, n. kăma, pl. kămannu,misali,supa*, š̆fa, wani*, e.g. his l. kamansa, supansa, waninsa or misalinsa; he gave me his 1 . (his portrait) ya ba ni kamansa.

likewise, adv. kuwa, ma*.

liking, n. k̦auna, k̦amna (S.).

lilac, African and Persian 1. (pride of India) kurnan nasara.

lily, water ḳwala (K.), bădo, kola bădo (S.); climbing 1. baurere; spider l. hatsin manoma.

limb, of body găba, pl. gabobi lime, $\mathrm{n}$. (the fruit) lemu, lemo. limit,n. iyaka,iyakachi,matuka. limping, dangyashi, dingishi. line, n. (row, series) jeri, pl. jerori, zăne*; in a l. a jera. or a jere; spec. a l. formed for prayer saffu; a broad blue 1. in cloth saki, or swaki; to draw up a l. of battle ja dāga; they are forming l. suna jeruwa; it is arranged in 1. ya jeru; a 1. of writing shatsăra, shadara ; to arrange in 1. zura, jera, jere; to form a l. yin. saffu; a l. of men bata; to. go in l. ja bata; see lines. line, a l. of writing shadăra, shatsara.

lineage, n. zuriya, usali, asali. linen, n. alkamura.

lines, coll. zane; to draw 1. zana or zani.

linger, intr. v. dăde, dada, nauwa; to l. about lalata.

lingerer, n. mai-nauwa; a l. at home in time of war kazum. lint, made from cottion taffa, tappa.

lintel, n. almanāni.

lion, n. zaki, zaiki*, fem. $z a-$ kanya, pl. zakoki, furdi*, wan dăwa, manyan dăwa; a male l. toron zaki; a young 1. dan zaki; a strong 1. wan dăwa; the adj. gadanga strong is specially used as an epithet of the lion.

lioness, n. zakanya. 
lip, n. lebo, lebe, pl. lebu, lebuna; lips dāburi, pl. daḅurori; a disease of the lips chizal; a disease on the under lip beli (K.), chande (S.); a disk embedded in the lips of pagans maran lebo, pelele*; thickness of lips nābuwa.

list, n. (written) zumami, takarda, pl. takardu, lisafi.

listen, v. (to hear with attention) saurara, sorara or jurare*; (to eavesdrop) lăbe ; to l. intently with bowed head karkata and karkasa used with or without kunne (ear).

listener, n. majiya, sauraro. little, adj. karami, fem. karama, karamiya, pl. karamu ; kankane, kankani, fem. kankanuwa, pl. k̦ankana, kanana; substantively (=a l., also few) kădan, sama sama, kīma, tsarari ; very l. kădan kădan, kima kima; I ate but very 1. ban chi ba sai kădan kădan; wait a l. while jima kădan or jim kădan; to take very 1. of tsakăra or tsakŭra; a l. chim.

ittleness, kankanta, karamchi. ive, intr. v. yin rai.

ivelihood, zaman duniya. iver, n. hanta, anta, kidibi*, gidibe*. living, adj. da rai, e.g. this is not a l. child wagga ba diya mai-rai ba che.

living One, the, adj., epithet of God mai-haya*.

lizard, n. kadangare, fem. kadangariya, kadangarwa, $\mathrm{pl}$. kadangarru; gwada, sharindo, sharundo; skink kulba; Sudan monitor (Varanus exanthematicus) damo; Nile monitor tsari, guza; a small brown 1. (Gecko) tsāka ; sarekutup, sarekutu, a small blackheaded l. gaguware; a l. with orange and black bars (Scinopus fasciatus) which buries itself in the sand damatsiri* (which also = the green snake); when the male l. puts on its mating colours it is called kutu in Kano, kiski in Sokoto, and jangwada in Zaria.

lo! bum*, duba.

load, n. kaya, pl. kayayaki, fugŭma, karḅa; heavy 1. adīla or adīlan kaya, alaro, sanji; a small addition to a carrier's 1. doriya; to get ready a 1 . gyāra kaya; to pack up a l. labda; I took his l. na taboshi. load, tr. v. labda; to 1. a gun dura (or chika) bindiga, kimsa, yin kimshi; to l. up dura. 
loadstone, n. mijin karife. loaf, n., of salt or sugar kantu. loafer, n. dan karma, see idle.

loan, n. ăro, bashi*, ramche; a cooperativel. adashi, adashe, wujiji; see lend.

loathe, tr. v. jin kyama. loathing, kyama, tsantsani. locality, n. wuri, pl. wurare. lock, n. makuli (K.), kubli, kuli; l. (padlock) of a door kwadon kofa.

lock, tr. v. kuble, kule; to lock. up, id. it is locked shina kule.

locks, of a woman's hair taura; see under hair.

locust, n. fara, pl. farori, faruna, gam, jinnu, farat tumfafiya; a large l. bābe, fem. babaniya, pl. babaye, babuna; a black 1. burduduwa, pl. burduduwuna; a black l. which flies at night faran-dare ; an insect like a l. taki, pl. takoki; young locusts ('hoppers') dango. locust-bean, dorowa*, dorawa; husk of 1.-b. makuba.

locust tree, n. dorowa, dorawa, pl. dorowayi; pod of $\mathrm{l}$. t. sabăda.

lodge, intr. v. sabka, sauka, sabki or sapka.

lodging-place, n. măshidi, masabki, masapki, masafki, majidi, masauki.

log, n. (of wood) itache and iche, spec. a l. of wood fastened to feet of slaves as a punishment turu; a l. of wood tied to the head as a punishment for thieving kangalai; l. fastened to the neck to prevent escape $g u$ dungumi.

loin, n. ḳugu, pl. ḳugogi ; māra, tsăra.

loin-cloth, a man's bante, banche; leather 1.-c. warki (K.), walki (S.); a woman's fatari, mukuru; a l.-c. which is the badge of a thief băkin bante.

loneliness, n. kewa.

long, adj. 1. (of considerable length) dogo, fem. doguwa, pl. dogaye, da tsayi.

2. (of dimension) expr. by n. tsawa, tsawo etc., e.g. it is seven cubits long tsawonsa kamu bakwai; see length.

3. (of time) how l.? tun yaushe? l. ago tuntuni ; from a l. time dadadde; l. since tun dadewa; l. lasting, adj. mai-dawami; (of space) a l. way off daga nesa, da nesa and nesa; a l. way da jayawa, da rata, da tabawa.

long for, v. tuski, tuske, kwa. 
daye, lamiranta ; to l. after, e.g. absent friend yin bege. longing, n. (also =l. for) kwadai, kări, marmari, kāawa (only used of women); evil l. guri; 1. for an absent friend bege.

look at, v. düba, dūbo, yin kallo, see behold; l. at this ! ga shi vannan; to l. attentively at tsokachi, yin zuru; to l. carefully into yin bibiya; to 1. for (seek) nema, bida; to 1 . into, constr. with da or acc. lura; to l. proudly on yin harāra*; looking round (i.e. spying) dauroro; to 1. out for hanga, hangi, hango; see espy; to l. over leke; looking over the wall leken garu; to l. like, cf. it looks like him shina da halamunshi or shina da halaman kamanshi; it looks like rain sama tana da halamun yin ruwa.

looking-glass, n. mădūbi, mădübin fuska, matsokachi.

loom, n., the pulley on the 1 . on which the peddles work chikalkora; the handle fixed into the pole of a l. matuki; the pole of 1 . on which the woven cloth is wound takala. loop, in a string, n. zarge, pl. zarguna ; mazargi, maballi. loose, adj., kwaranga (S.), kwaraprap (K.); (my shoe) is too l. for me ya yi kwaro kwaro.

loosen, tr. v. kunche, kwanche (K.), banya, banye, sassabta, sassafta, sassapta, sunche, bambare; to come loose (e.g. of head of an axe) kwăbe.

loosened, particip. kunchache, fem. kunchachiya, pl. kunchachu.

loosening, n. kunta, kwabiya*. loot, e.g. the sack of a town buruntu.

lop, to kudure.

lopping, of branches sāran bisa.

lord, n. ubangiji; sidi applied to Mohammed; Lord, an epithet of the Deity, rabbi*, ubangiji.

lose, tr. v. răsa, yin rashi, ḅăta, yin hasāra, gagata, the last constr. with da, rubushi; to 1. the way răsa hanya, gagata da hanya, ratse, gochi and goche, gwabche (S.), b̆ăta (or băche) hanya, dimanta, dimauta, karkache, the last also tig. of moral deviation; to 1. one's case kayas ga shari'a ; they lost heart hankulansu duka sun tashi; losing băchewa; see lost. loss, n. barna, e.g. they caused 
him 1. su kai ma shi barna; rashi, hasāra, asāra, tasari, ta'adi, ta'ada, taskăro (S.), tasgăro (Daura), k̦ampa, k̦amfa. loss, to suffer, intr. v. yin hasāra, yin ta'adi.

lost, n., the state of being l., e.g. in the forest dimana*.

lost, particip. lalatachche, fem. lalatachchiya, lalatattu; to be 1. băche, makuwa, răsa. lot, n. (portion) rabo or rabu, pl. raberabi.

lots, coll. kuriya; to draw 1. yin kuriya.

louse, kwarkwata, kwalkwata, қyaya, қyeya; crab-l. dan kadafi; see also lice.

love, n. soyaiya, soyayya, sowaya, soyuwa (S.), l̦amna, laana, so*, muhibba.

love, tr. v. so, san* ; (after pronouns ending in na) $\mathrm{kam}$ na, kamnache; soye, yin soyaiya; sha'awa.

love-bird(Agapornis pullaria), tsiriya.

love-charms, tsibbu.

loved, one much, n. lele*, masoyi*.

lover, n. maso, pl. masowa; masoyi, pl. masoya.

low, intr. v. yin boda, see lowing.

low, adv. a ḳăsa, a ḳas; lower na ḳasa, fem. ta ḳăsa. lower, tr. v. Kasashe, sabka, sapka, safka, sauka, sabki, sauki, sabkas da, saukad da; to 1 . to the ground kasa; to 1. a bucket into a well zire.

lowering, participial n. (a bucket into a well) zirawa. lowing, $n$. (of cow or camel) boda, umbu.

luck, n. (good) nasara, arziki, gamon-katar, gata, gatanchi ; he has brought me good 1 . ya yi ma ni gata, katar, kătari.

lucky, to be aruzzuka; a 1 . day buruji, yin daula; a 1. person dangware, mai-arziki. luggage, n. kaya, pl. kayayeki; spec. a woman's 1. fago, faggo or pago.

lull, tr. v. rene.

lump, n. (e.g. of flour) dunkule; tsāba or tsala*, bangori.

lunatic, tabi, tăbu, tăbo, fem. tăbuwa; mahaukachi, fem. mahaukachiya, pl. mahaukata, tabaḅbe, shinkinkimi; see fool.

lung-fish, Gambian 1.-f. or mud-fish, i.e. Protopterus annectens gaiwa.

lungs, n. fufu, kufu, sufe (S.), pl. sufofi.

lust, n. gūri, sha'avva, kwadayi.

luxury, būki, marmari. 
lying down, n. kwantawa; 1. on the back with the legs up rigingini, rigingine.

lying in wait, n. fako, kwanto. lynx, (caracal) dage.

macaroni, n. taliya*, wasawasa.

mad, adj. mahaukachi, fem. mahaukachiya, pl. mahaukata; mai-hauka; a m. dog mahaukachin kăre.

mad, to be, intr. v. hauka, haukache.

madden, tr. v. haukata. madman, dolo, fem. doluwa, pl. dololi; you m.! kai yofi (S.) ; see fool.

madness, n. hauka, wāhami, tabuwa; stark m. hauka ja. maggot, tsutsa.

magic, n. maita, siddabaru, tsibbu, akokari, dabo.

magnet, n. mijin laarife.

magnify, tr. v. (to honour, or extol) girmama, bada girma, yin yabo.

magnitude, n. girma, e.g. the sun surpasses the moon in m. rana ta $f i$ wata girma. magpie, n., Senegal m. (also used for 'ox-pecker') charki. mahogany, tree madachi; m.bean tree kawo.

maid, an old m. tuzuruwa. maiden, n. buduruwa, pl. budurai, diya; a young $\mathrm{m}$. bera.

maidenhood, n. budurchi or buduruwanchi.

mail, coat of, n. (made of cloth) lifidi ; (made of chain) sulke, safa, kumakumi.

mail-clad, pl. masu-lifidi.

maimed, adj. laduru.

maintain, tr. v. 1. (to retain)

rike, rika, riki.

2. (to feed) chida.

maize, n. masara, dawa ma. sara or damasara* (i.e. dan masara); roasted m. bambara; a m.-cobgoyon masara; see corn.

make, tr. v. 1. (to construct, fashion, create) $y i$, yiwa, yiwo, iwo*, yo, wa; I m. $n a i=n a$ yi ; (to produce or effect) e.g. to m. an outery yin kururuwa.

2. (to cause) $s a$, e.g. they $\mathrm{m}$. the householder run away sun sa mai-gida shi guje.

malady, n. chiwo, chiwuta; see under ill.

male, adj. and n. namiji, pl. mazaje, toro*; the m. lion toron zaki; $\mathrm{m}$. and female namiji da tamata.

malice, n. k̦iyaiya, k̦iyayya, masīfa, keta, mugun hali mugunta, tsēgumi.

malingering, sāne. 
mallam, (teacher or learned man) n. malam, malami, pl. mallamai; chief m. liman* or limami*.

mallet, for beating leather kantukulo.

mallow, Jews' m. malafiya. maltreat, tr. v. walakanta, wulakanta; see injure.

maltreatment, n. walakanchi. man, n. mutum or mutume, pl. mutane; (as contrasted with woman and wife) miji, pl. măza, mazaje, mazaizai; maimiji; married m. miji da mache; the $\mathrm{m}$. with the broom (i.e. a bachelor who has to sweep his own house) namiji da shara.

manacles, see chains.

manatee, the African species of $\mathrm{m}$. ayu.

mane, n. (of horse, etc.) geza, pl. gezuna, rabaja (S.).

mango, mangoro* (a word used by traders).

manifest, adj. zahiri.

manifest, tr. v. bayăna, baiyana, gaya, gwada.

manifestation, n. nunawa. manifestly, adv, zahiri. manioc, rogo.

manis, n. (i.e. pangolin, a kind of ant-eater)kirikiri,kikiriki. mankind, coll. mutane duka, dukan mutane, duniya. manliness, n. mazakuta, mazakunta, mazakunchi.

manner, n. hăli, pl. hălaye, ada, the latter used especially of religious m.; such is his m. halinsa ke nan.

manners, coll., good m. kumya, kunya, lădabi; want of good m. rashin kumya.

mantis, dokin Allah, dan kama, koki.

manumission, n. (of slaves) mudăbar ; a certificate of $\mathrm{m}$. laya, layan diyauchi.

manure, n. taki.

manure, tr. v. takanta, yin taki.

manuscript, a m. from which a copy has been mado $u w a^{*}$.

many, adj. dayawa and (esp. of persons) maiyawa, pl. masu-yawa; barkatai, fal (S.), pal, pul* (K.), rututu (Zanf.); how m.? năwa, guda năwa, e.g. how $\mathrm{m}$. years is it since your birth? shekara năwa tun haifuwarka? how m. were there? sun yi năwa? marabout, the bastard jinjimi.

march, by night in war, $n$. kwanan daga.

mare, n. godiya, pl. gwaddi, dukusa (fem. of dukushi) pl. dukusai; a young m. dan 
dukushi; a large m. ingarmiya, ingaramniya; a brood w. kabama, kabuma, kam. bama.

margin, m. of a page baycala, kora.

mark, n. tabo, tambo (S.), pl. tabuna; a in. on paper or cloth dugo or diga, pl. diyogi; m. on animals, trees, etc. or of a person unable to write shaida, pl. shaidai, slıaidu; a m. on the ground, a land-mark amara; for tribal marks see marks.

mark, tr. v. 1. (to note, observe) $j i$, gani.

2. to make a m. on shaida or yin shaida, kaskasta, kyaskyasta ; to m. off kebe, kebanche, alanta; to m. out on the ground shaya, shata, shan wuri.

marker, in book, n. halāma, alāma, amara.

market, for some special article, n. kasuwa, kausuwa (Zanf.); spec. a very small m. dan kasuwa; ofticer of the m. sankurmi; president of the $\mathrm{m}$. sarikin kasuwa.

marketing, sayaya.

marks, coll. (cut on face to point out tribe etc. to which a person belongs) shaushawa, jarfa, shatani, zŭbe, kyaskyas- $t u$, e.g. (m. cut from the corners of the mouth) yambaka; (m. on cheek nearly horizontal) bille (K.); tattoo m. behind the eyes kadango; m. painted on faces of women katambiri; tribal $\mathrm{m}$. on temple kurmajo (Zanf.); the Beriberi tribal mark tsagan goshi; to cut tribal m. shceushauta. marksman, n. mahalbi, pl. mahalba or masu-halbi.

marriage, n. amre, amri, aure, arme (S.), anganchi; to give in m. amrad da; m. feast buki or biki, also wasam buki; m. presents (wife's) gāra; to rejoice at a m. yin gāra. married, adj., a m. man miji mai-mache, magidanchi;

a $\mathrm{m}$. woman mache maimiji. marrow, n. bargo, lăka*; m. bone tantakwashi.

marry, v. amre, aure or yin amre, damre amre, darme arme (S.).

marsh, n. fädama, dausayi. martyrdom, shāhada*. marvel, n. (a wonder) abin mamaki, abin chevva, ajub*, ajaba.

marvel, v. yin mamaki, jin mamaki, yin woba; to $\mathrm{m}$. at a thing unseen before $k \bar{a} k \bar{a} b i$. mash, tr. v. farfasha or palpa. she, kirba, tüke. 
mashed, participial adj. dakak$k e$, fem. dakakka, pl. dakakku. mashing, n. (e.g. of yams) kirḅi.

mass, n. tsaba; a m. of anything zuri (K.).

master, n. ubangiji; uba, p]. ubanne, ubanai.

master, tr. v. (to overpower) rinjayi or rinjaya, $f^{*}, i^{*}$. masticate, tr. v. tamna or tauna, tsuke.

masticated, particip. tamnanne, fem. tamnanna, pl. tamnannu.

mat, n. gen. abin shimfida, mashimfidi; a grass m. leso ; spec. an old grass m. kēso; a reed m. tabarma; a goatskin m. buzu, kilishi; a round m. tăfin giwa; a round grass m. wundi, windi (S.), asalo; a mat let down in front of a doorway asabari, tufaniya, mayamfadi (S.) ; a grass or reed $m$. for covering the outside of houses $z \bar{a} n a$; a split-cane woven $\mathrm{m}$. kwăra-kwăra; a m. used as a door cover kyaure ; a hanging m. tihu, tifu; a m. made of palm leaves mulli, murli, gazari; see mats.

match, (fellow) tsāra, pl. tsarara-raki; look for your m. nema tsaranka. matches, ashana*; to strike m. kyarta or karta ashana. mats, coll. (used for rooting) amāme; grass used for making m. tsintsiya*.

matter, n. (subject) tada, pl. tadodi; what is the m.? mi ya faru? what is the m. with you? mi ya same ka?

mattress, cloth, n. darduma, katifa.

mature, adj. and v. nena; see ripe.

me, personal pron. $n i$, e.g. he caused me fear ya ba ni tsoro, they followed me sun bi ni; with prep. to me ma ni, gare $n i$; exclamatory, me! do you mean me? niya?

meal, n. 1. (repast) kalachi, which also $=$ midday $\mathrm{m}$.

2. (ground corn etc.) gari; see flour.

mean, n. (midway position) matsakaichi.

mean, adj. (worthless, contemptible) lalatachche, fem. lalatachchiya, pl. lalatattu, banza.

meaning, n., e.g. the m. of a word or a phrase loga, gutsu, tushe, azanchi, baichi, kări, ma'ana, dalili* ; e.g. there is no $\mathrm{m}$. in it $b a b u \log \alpha$; what is the $\mathrm{m}$. of it? 
minene gutsunsa or wannan ina ma'ana tasa?

measles, n. karambau, karimbau.

measure, n. 1. gen., both in the strict sense and also of comparison, estimation, proportion, one's m. or standard gwalgwado, gwargwado.

2. an instrument or means of measuring abin auna, abin awo, ma-auna, magwadi, magwaji.

3. spec. the foot regarded as a m. of length taki, pl. take-take; a m. of length from elbow to tip of middle finger kamu; a cloth $\mathrm{m}$. of about 15 feet zane, pl. zannuwa or zanna; a m. of capacity mǘdu (K.), pl. muduna; a m. for grain $z a k k a$ (S.) ; see span.

measure, tr. v. gwalgwada, gwargwada, gwada, awo, yin awo, auna; to $\mathrm{m}$. with the thumb and middle finger $r a$ $t s a$; to $\mathrm{m}$. with the hand $t a ̆ k a$. measuring, 1. participial $\mathrm{n}$. gwalgwadawa.

2. anything used for $\mathrm{m}$.; see measure (2).

meat, n. (flesh used as food) nama, pl. namomi, dāgu (K.), yome (S.) ; spec. thin strips of cooked m. kilushi, kilis; a piece of $\mathrm{m}$. roasted on a stick chanchanga, tsire, tsiri, pl. tsirare; a small piece of m. tsoka (S.), pl. tsokoki; thin strips of $\mathrm{m}$. dried in the sun yāwara; the fat of $\mathrm{m}$. mai, kitse; epithet applied to broth without m. da lami.

meddlesome, kasarantam. meddlesomeness, karambāni, kazalaha.

mediator, n. matsakanchi. medicine, n. māgani, pl. maganguna, magunguna; to take m. sha or hade mägani; to administer m. $s a, b a$ or bada māgani; a $\mathrm{m}$. for the eyes korino, giwakamba; a m. taken to ward off an enemy's blows sagau; a m. for children dauri; sources of m.-a tree whose root is used as a $\mathrm{m}$. for dysentery domashi; a sharp, thorny grass ground up as a $\mathrm{m}$. rairai; a root used as a purgative m. zagarafi; a plant with small black seeds from which a purgative $m$. is made nanăf $a$; see also tsuhu, tsumi, etc. ; m. consisting of charms tsubbu, tsibbu, dabo.

Medina, Madina.

meditate, intr. v. zache; see think. 
meditation, n. tunane, tunanne, pl. tunannu.

Mediterranean Sea, Bahar Ilmal.

medium, (average) tsăka-tsăka; m. sized matashi.

meek, adj. da hanḳuri; cf. seq.

meekness, n. hankuri, hankura.

meet, adj. daidai, and in stronger sense halal, halas; not m. haram, ba daidai, ba halal etc. ; cf. seq. (2).

meet, v. 1. tăriye, tăra, yin tăriya, (to assemble) tāra; to $\mathrm{m}$. as in conflict or opposition karo with $d a$; to $\mathrm{m}$. with gămu or gamo da; tare or tarda, taras da, tariyo*; tsaya da; same or samo; hăda da, Karamta da, sādu; to m. a person coming from the opposite direction karamta $d a$; to m. (i.e. to reach to) taras ; to go to m. tarba (S.) ; to m. unexpectedly chin kăro.

2. (to $\mathrm{m}$. so as to be fit, suitable, sufficient) gamshe, ishe; this meets our case wannan ya ishe mu.

meeting, n. taruwa, (assembling) tāriya; m. of rivers (confluence) magangami; a day of $m$. (with God on the last day) ran gamu; an un- expected m. kachibis, kitibis; they have met sun yi kachibis.

melon, n. dila*; spec. waterm. guna, kankana.

melt, tr. v. (e.g. metals) narke, narka ; it is just at melting point ina kan narkewa. melted, be, intr. v. narku. melted, participle narkakke, fem. narkakka, pl. narkakku. melting, n. narki.

memorandum, of goods, written on paper, n. zumami, zumame.

memorial, n. ambăto.

memory, n. tunane*, tuna*, famu.

men, n. 1. (males) măza, mazaje, mazaizai.

2. (human beings) mutane. mend, tr. v. 1. gyarta, gyara. 2. to patch clothes etc. banke, lallaba, toshe, taushe. 3. fig. (to set right, to ' $\mathrm{m}$. matters ') gyara.

4. to m. a road tāda hanya.

mendicant, n., see beggar. mending, participial form gyartawa.

mention, tr. v. ambăta, ambăto, ambache. merchandise, n. bukāta, abin chiniki, fatauchi, urula. merchant, n. falke, fem. fal- 
kiya, pl. fatake, ătajiri or tăjiri, mai-fatauchi, dan garumfa*; see trader.

merciful, adj. (epithet applied to God only) errahimi*.

mercy, n. jinkai, tausayi*; see compassion.

merely, adv. sai dai, sai.

message, $\mathrm{n}$. (errand, mission) sako, (news or information brought) labāri, jawābi; to complete the delivery of a m. ida labāri.

messenger, n. maaike, maaiki, pl. masu-aike; jekāda, jakāda, fem. jekādiya, makirayi; manzo, pl. manzanni, which is also specially used of a king's $\mathrm{m}$.

messiah, the almasihu.

meteorite, gatarin arādu.

midday, n., of time tsakar rana.

middle, n. tsăkiya, tsăka, a tsăka; the space between two places or things tsăkani; in the $\mathrm{m}$. of (prepositional phr.) tsăkani; to be in the m. tsăkaita.

midge, ('sand-fly') kyashi, kyarfirfita.

midnight, tsăkan dăre.

midst, $n$., see middle.

midwife, n. ungozuma, ungozoma, unguwanzoma, ingozoma. might, n. iko, (of physical power) karifi, karfi; with m. $d a$ iko.

mighty, adj. mai-iko, maikarifi, bajini*, gugara* ; (as epithets of God) jabbaru, aljabbaru, jalala; see powerful.

mignonette, an amaranth plant with a flower like $\mathrm{m}$. zaki banza. It is closely related to the native spinach; cf. alayafu.

migrate, to zakuda, zauda.

migration, kaura; a place to which anyone migrates $m a$ kaurachi.

mildew, n. fumfuna, funfuna, fufuna, damshi, laima, lamniya, rima.

milk, n. nono, pl. nonuna; sweet or fresh m. mădara; curds of $\mathrm{m}$. guntsari; $\mathrm{m}$. and water tsararauka; a herb, the root of which is put in $\mathrm{m}$. to preserve it loda, dafara; to skim m. yade.

milk, tr v. tatsa, tatse, twache, twatsa (S.).

milkweed, gigantic m. or Dead Sea apple (Calotropsis procera) tumfafiya. mill, n., see millstone. mill, tr. v. (to grind) nika. miller and mill-owner, $n$. mai-reda. 
millet, n., bastard m. tumbin jaki; bulrush or pearl $\mathrm{m}$. gero, maiwa; great m. dawa; 'marua' or 'ragi' m. tamba; the first ripe heads of $\mathrm{m}$. before the general crop is ripe tumu; m. which has sprung up by itself on an unsown farm yăbări.

million, adj. alif alif; dubu dari goma.

millipede, kadandoniya, aima$k a$; see centipede.

millstone, n. dutsin nika, niki, maredi, pl. maredai. mimosa, kaidaji; Egyptian m. bagaruwa.

minaret, hasumiya (S.), sumiya (S.), sumaya (K.).

mince, tr. v. (cut into very small pieces) yanyana.

mind, n. zuchiya*; I am of two minds ina da zuchiya biyu.

mind, v. (to regard, heed) kula with $d a$, see care.

mine, sep. possess. pron. nawa when obj. possessed is masc., tawa when fem., e.g. your horse is stronger than $m$. dokinka ya fi nawa karifi. mingle, tr. v. chudaya, see mix. minimum, kadane*.

minister, a king's, n. bafade,

pl. mafadawa; $m$. of the household magaji. minstrel, n. zabiya, pl. zabiyoyi.

minute, n., of time gari*, diga.

mirage, n. diyal-rana (lit. child of the sun), kawalwalniya. mire, n. lāka, tabo, pl. tabuna; see mud.

mirror, n. madubi, madubin. ido, madubin fuska, matsokachi.

miscarry, v. bari, yasda diya, bata chiki*, lalache.

mischief, n. keta, masīfa, ḅar$n a$; to do m. yin sabăbi ; m. making kwarmato*.

mischief-maker,n.mai-sababi,

pl. masu-sababi; machuchi. mischievous person, n. maimasīfa, mai-ta'adi.

miser, n. bahili, marowachi.

miserable, to be or to render m. sinihi.

misery, n., see distress.

misfortune, n. hasāra, asāra, tasari, sababi, mayāta, masīfa, halaka or hallaka.

mislead, tr. v. rude; one who misleads marude or mai-rude, pl. maruda.

misled, particip. rudadde, fem. rudadda, pl. rudaddu.

miss, n., used of an arrow, gun, etc. kuskurewa.

miss, v. (e.g. to pass over, omit words in a book) ratsa* 
fatara; to $\mathrm{m}$. the way ratsa hanya; to $\mathrm{m}$. (of an arrow) kuskure, kurkura, ķure (S.), yin kundu ; to m. fire fäsa ; to m. one's aim baude; shan kuskure, shan bara; to in. or fail to meet yin swabāani. missing, used of two persons $m$. each other on a road swabani. mist, n. hăzo, feshi, kāasashi.

mistake, n. mantuwa, rikichi, pl. rikita, rikichewa; kure, pl. kurakuri; I made a m. na yi kure; to make a $\mathrm{m}$. manta, manche, yinmantuwa, bata zanche.

mistletoe, West Indian $\mathrm{m}$. kauchi.

mistress, n., m. of the house uwargida, uwalgida, m. of slaves uwargijiya.

misty, adj. da hăzo.

misunderstand, v. gigiche. misunderstanding, gigi.

mix, tr. v. dāme or dāma, garwaya, gangama, kwābe, kwāba, gauraye, hautsina, karla; to m. together chuda or chudaya, surka, yamutsa, yamuche; to m. mud churla yimḅu, chuda; mixing chu!lawa.

mixed, what is, e.g. mortar, n. damamiya.

mixing, gămawa, yauraya, kwaḅi, surki. moat, baza, gwalalo.

mob, gungu.

mock, v. bananche, yin ba'a, yin gori, reda.

mockery, ba'a,bananchi, gaiya, gori, izgili.

mode, n. hăli, pl. hălaye.

moderate size, n., a thing of

m. s. madaidaichi.

moderately, adv. da dama dama.

modest, adj. (bashful, or under a sense of shame) da kumya. modesty, n. (sense of shame, bashfulness) kumya, kunya. Mohammed, pr. n. Muhammadu, Muhammad, Ahmadu, Ahamadu, dan Amina.

mohammedan, a, n. musulmi, pl. musulmai; the m. religion musulumchi; to be a $\mathrm{m}$. musulumta; I changed from a heathen to a m. na sauyad da arna musulmi.

moist, m. ground dausayi, laima, $\operatorname{dimau}(\mathrm{S}$.).

moisten, tr. v. jǔka, jǔke.

moisture, n. damshi, rima; see damp.

molar, a m. tooth matamni, pl. matamna.

molasses, a kind of, n. mă marliya.

mole, n. (birth-mark) tadawal Allah; an animal resembling a large m. yyabji. 
molest, tr. v. tsananta, alale. moment, n., of time kyaptawan ido, gari*; in a $\mathrm{m}$. (forthwith). nan da nan.

Monday, n. litini, latini and ranal latini, attanin (S.).

money, n. kurdi, kudi; for $\mathrm{m}$., on payment of $\mathrm{m}$. $d a$ kurdi; (the only money regularly used by the Hausas consists of cowrie shells, about 2000 of which are equivalent in value to a shilling; the Austrian dollar is occasionally used, see dala); ready m., i.e. cash down hannu da hannu; much m. kurdaidai, kurade (S.). money-bag, small, n. tsaleta. mongoose, a species of ayarabi. monitor, guza, damo, tsari. monkey, n. b̌ri, fem. birinya, pl. birai, b̌raye or bĭruna; different species are: jan biri, kirka, bi kuka, gata or gatan b̌ri; a small reddish m. tsula; an old m. gauji; a baboon gogo, gwaggwo, yimki (K.), bika (masc.). monkey-bread, tree, n., i.e. the baobab kuka. monkey-nut, n. gyada; oil from the m.-n. main gyada. month, n. masc. wata, pl. watanni; this m. watan yau; last m. watan jiya; next m. watan gobe; the m. after next watan jibi ; four months wata fudu; the fourth $\cdot \mathrm{m}$. wata na-fudu.

monument, n., see memorial. moon, n. wata, pl. watanni, masc.; the new m. sabon wata, farin wata, jinjirin wata (S.); a new m. when seen with the old $\mathrm{m}$. amariyan wata; moon-light farin wata; a bright m. wata farifat; a halo round the $\mathrm{m}$. sansani; phr. the m. is ended wata ya mutu; the m. is new wata ya tsaya.

more, adj. 1. (greaterinamount) mafi-yawa, e.g. he gave him books $\mathrm{m}$. than ours ya ba shi litatafi mafi-yawadăganamu; $m$. considerable than this mafi-girma dăga nan.

2. (to a greater degree) as in our comparison of adj. and $\operatorname{adv} . f$, e.g. he is m. cunning than a ground squirrel ya $f$ kurege wayo; he likes me m. than you ya fi so na da kai; faye, faskare, e.g. you ask m. than I am equal to kana son abin da (ya faye ma ni or) ya faskare ni.

3 . (m. in addition, further) kara, e.g. add m. (to the price in bargaining) ka kara $m a ~ n i$; give me m. money 
dacla ma ni kurdi; he is asking for m. ya ke reman kari; although they made every attempt to console him, he cried the m. koda suka yi koḳari dayawa sun ba shi hankuri shi ya kara kuka; he stabbed him, then he moved no m. ya yanke shi baya nan bai ķara yin motsi ba; a little m. da dama; much m. bale, bare, balanta, e.g. he would receive anyone, much $\mathrm{m}$. would he receive me ya dauki kowa balanta niya.

moreover, adv. bayan hăka, $f a^{*}$, ananan.

morning, n., the early m. safe and safiya; when m. came $d a$ safe ya $y i$; in the $m$. da safe; every m. kowache safiya; good morning! sanu da safe or sanu da rana; very early in the m. sassafe; m. two hours after sunrise hantsi.

morning-glory, (plant) yako, yaryadi.

morrow, n. yobe, rana maizuwa; good-bye till to-morrow sai gobe; for 'day after tomorrow' etc., see day.

morsel, n. gutsura, pl. gutsure. mortar, n. 1. (made by scooping out a log) turumi, pl. turame.
2. (building cement) $d a m \alpha$ miya, damamma (S.); to mix m. dāme or dāma.

mortgage, to tolma, see pledge. moslem, n. musulmi, pl. musulmai; see mohammedan.

mosque, n. masallachi, pl. masallatai or masallataye.

mosquito, săbro, sauro, samro, pl. sabruna or sabraye.

most, adv. 1. (denoting the relative superlative) is expressed by a defining phr. mafi (or ya fi) duka (or kowa), i.e. surpassing all or any, e.g. he is the m. powerful shina da karifi ya $f i$ duka; for similar phrases cf. the $m$. excellent Mohammed Muhammadu ya fi kowa; $\mathrm{He}$ (i.e. God) who is m. powerful mai-iko da kowa.

2. the absolute superlative (=in a very high degree) faye, e.g. the cat is $m$. addicted to crying at night kyanua ta faye yin kuka da dare.

moth, n. gishi, majibari, buto wuta, bamota*; spec. a m. from a black caterpillar aso, asu; a $\mathrm{m}$. with red abdomen, white thorax and black and orange wings $g a$ madidi. 
mother, n. uwa, iya, inna (S.), jatoma*, gyatuma*; children of one m. chiki daya. mother-in-law, n. sarakuwa, surǔka.

motion, n. motsi. mould, n. alashaf. mound, n. tudu, pl. tudodi. mount, v. hawa or hau; to $\mathrm{m}$. a horse or to m. on horseback hawa doki or hawa bisa doki ; to m. up or upon $t \bar{a} k a$, taki, taska; to cause to $\mathrm{m}$. hawas da, haushe.

mountain, n. tudu, pl. tudodi, tudunduna, tsauni.

mourn, v. yin tăkaba, yin kuka, yin makoki.

mouse, n. bera (K.) or lira, dam bera, damḅariya, kūsu (S.), pl. kusa; the striped or zebra m. barewar kusu; water m. (or cane-rat) beran kyamro; a poison used to destroy mice madat, madas; a special name given to a $\mathrm{m}$. mi-kwana-ka-ba-ni.

mouth, n. baki, pl. bakuna; also tig. of the opening or entrance to anything, e.g. the m. of a well bakin rijiya; spec. a disease at the corners of the m. dacha, datsa; to fill the m. gumde.

mouthful, n. loma, lauma*. move, v. tr. and intr. motsa, intr. yin motsi; to m. away from gurgusa, gurgushe; to m. a little back gusa, gulgusa, gurgusa; to m. a little forward guso or gurguso; to m. backwards and forwards gusa, guso; to m. forward or backward so as to make room zakuda, zauda; to $\mathrm{m}$. nearer to the speaker zakudo; to m. from a place gurgushe; to m. towards gurguso; it cannot be moved ya ki motsuwa.

movement, n. motsi. moving, m. a little away, particip. gusawa.

mow, tr. v. yanka or yanke.

much, 1. adj. and adv. (in great quantity) yawa*, dayawa, mai-yawa, e.g. m. money kurdi dayawa; he rejoiced m. ya yi murna dayawa; yawa connective form yawan, da gugu, connect. gugun, gugin, tuli, rututu (Zanf.), sununu, e.g. m. sand gugun rairai; how m. ? năwa, rauwa? e.g. how m. money am I to give you? kurdi năwa ni ba ka? to do something very m. faye, e.g. children laugh very m. yara sun faye yin dariya; to be too m. for buwaya or buwaye, faskare, e.g. it is too $\mathrm{m}$. for 
me ya buwaye $n i$; it is too m. ba shi kai hakanan ba or ya faskare; m. more bale, bare, barshe, or with preceding negative much less; very m. pal (K.), fal (S.).

mucus, from the eyes, $n$. kwamtsa, kwantsa, kwamtso. mud, n. yimbu, yamlu, yumbu, taḅo, pl. taḅuna, lāka, șăfo, kăfau, potopoto ; spec. a handful of m. churi; a round piece of $\mathrm{m}$. chibirin kasa; slippery m. talalabiya*; m. or sand in water yashi.

muddy, adj. da tabo ; m. water gwiḅa, gwiţi, gurbatachen ruwa; to make m. gurbatc. mud-fish, or Gambian lungfish, i.e. Protopterus annectens, n. gaiuca; noise made by the m.-f. chiwuki, tsuki (S.).

muezzin, n. ladān, ladāni, wazanu (S.), wazinu, maikiran salla.

mule, n. alfadari, fem. alf $f-$ dara, pl. alfadaru, alfadarai.

multiply, tr. v. yawanta, kara**, riba; I multiplied it by ten na riba shi goma.

multitude, n. yawa, taro or taru, pl. tarori.

murder, n. kăshinkai, kǐsankai. murder, intr. v. yin kăshinkai, yin kĭsankai.

murderer, n. makashi, makashinkai, see kill.

murmur, intr. v. yin gunaguni.

muscular person, n. gyande, fem. gyandiya.

mushroom, naman kaza.

music, n. molo, maulo, pl. moluna; to play music yin wasa. musical instrument, n. abin molo, kicla, kidi ; any kind of wind $\mathrm{m}$. i. busa, pl. bushebushe; to play on a m. i. that is touched or struck yin kidi; spec. a m. i. like a guitar gurumi or gurimi; a m. i. held under the arm, a kind of drum kotso; a m. i. made of a long gourd zunyuru; a m. i. played by rubbing on it kukuma; a stringed m. i. matsirkiya; strings of a m. i. tsarkiya; a stick for m. i. goge; a m. i. played before a king pampami, famfami, a wind $\mathrm{m}$. i. siriki, a wind m. i. resembling a bagpipe clgaitc, algaitu; a trumpet or trombone kakaki. musician, king's, n. zabiya (K.), zabayce (S.), pl. zabiyoyi; m. who performs on a drum, n. makidi; on trumpet mai-busa. 
musk, n. muska.

muslin, n., used for turbans harsa, hassa, hirsa.

mussel, pond-m. kumba.

mussulman, to be a, intr. v. musulumta*; see mohammedan.

must, v. (i.e. be obligatory or necessary) lalle, kamata, e.g. we must work lalle ne (or ya kamata) mu yi aiki; see necessary.

musty smell, as of grain long kept, n. suna*.

mutilate, to gunche, kire; mutilating kirewa. mutilation, e.g. loss of hand or foot dungulmi, gundulmi. muttering, jiza.

muzzle, for goat or donkey,

n. takunkumi.

my, possess. pron. 1. suff. $-n a$ when the obj. possessed is masc., $-t a$ when fem., e.g. my father ubana, my mother uwata.

2. separate, nawa with masc., tawa and tata* with fem., e.g. my horse doki nawa; my mare godiya tawa. myriad, n., of number ribbi*. myrrh, jawal.

myself, pron. kaina; I m. ni da kaina.

nail, finger-n. kumba, pl. kumbuna or kumbai, farchi, farche.

nail, an iron, n. kiussa. nail, tr. v. kăfa.

naked, adj. tsirara, funtu, huntu, da tsiraichi, maitsiraichi or da funtu, jir; a n. person tumbar*; he is n. ya yi tsirara.

nakedness, n. tsiraichi, funtunchi, kăsau ; wofi, e.g. a naked lie kariyar wofi.

name, n. suna, pl. sunaye, sunanaki; a city whose $\mathrm{n}$. is Kano birni sunansa Kano; what is his n.? wa sunansa? or mi an che da shi? phr. name its price $b a$ shi suna. name-day, for a child, n. ran suna; a meal connected with the n.-day tuwon suna.

napkin, n. kalkăfi, maharma. narrate, v. fadi, fada.

narrative, n. labāri, aljama. narrow, adj. kumchi, kunchi, kunkunta; a n. place wurin matse.

narrow, v. 1. tr. (to make n.) kumtata.

2. intr. (to be n.) matsu. narrowness, n. ḳmchi, kunchi.

natal, adj. na-haifuwa, fem. ta-haifuwa, e.g. your n. day rana ta haifuwarka or ranan (ran) haifuwarka. 
nation, alumma or al'umma. native, 1. adj. (of animals, etc. belonging to a particular country or district) expressed by means of lasa or gari, e.g. the $n$. trees itatuwan kasa; the n. fish kifayen garinga.

2. gentilic n. (a native) of a country $b a$ with terminal vowel $e$ or $i$, e.g. a Hausa n. ba-Haushe; of a town or locality $d_{a}$ followed by its name, e.g. a n. of Zaria dan Zazzau.

nativity, n. haifuwa.

natron, n. kanwa, gallo; a heap of n. burdumi*.

nature, n. (character) hali.

nausea, tsanda (K.).

navel, n. chībi (S.), chībiya (K.), pl. chibobi.

near, adv. da kŭsa, kŭsa, e.g. he went n. ya tafi kusa; he sat $\mathrm{n}$. at hand ya zamna kŭsa ; very n. kusa-kusa, kurkusa, kulkǐsa; n. to kǔsa da or kŭsa ga; n. to him kŭsa gare shi.

near, to be etc., v. intr. to be or draw n. yin kŭsa, kŭsata, kusache, kusanta; to draw n. düno; to draw n. to gwamatsi, shinkaya*.

near, coming n., participial form kŭsatowa. nearly, adv. kusa; it is $\mathrm{n}$. finished ya yi kusan karewa or ya kǔsa karewa; he n. forgot it ya kŭsa manta shi. nearness, (proximity) kŭsa. necessary, adj. wajib, wajibi, lazumtache; the necessaries of life abin bukātar rai.

necessary, to be, v. wajaba, wajiba, lazumche, kamata; impers. it is n. ya wajiba, ya kamata, lalle ne.

necessity, n. larura, lalle, tìlas; of n. cla lalle, da tĩlas, da wuya, wajib, wajibi.

neck, n. wuya, wiya, pl. wiyayi. neck-hole, of shirt, n. wundi. necklace, mäkŭura, n. of red beads kutofi; (worn by women) dumbujin zufa; a n. composed of black seeds kantururuwa, tagode.

need, n. bukäta.

need, v. bukata, yin bukata; cf. prec.

needful, it is, impers. ya kamata, lalle ne.

needle, n. alura, p]. alurai, madunkiya, matsiyachiya, matsefata*, tamfasuwa, tan fusurva; spec. large n. tsiko, sumjiya, sumdiya; a sail-n. masilla, misilla; a large curved $n$. used for thatching bida (S.) ; a needle's eye $k a ̄ f a l$ alura. 
needle-case, n. gidan alura. needlework, e.g. yellow n. on a burnous, n. yarrani*. needy, adj. makaskaschi, pl. makaskasta, talaka, pl. talakawa or talakka, mai-talaka, pl. masu-talaka, mai-talauchi, pl. masu-talauchi.

neglect, n., e.g. of work kwatakwana*.

neglect, tr. v. kyale, rena, shāmuke; (to take no notice of) zuba idanu.

neigh, intr. v. yin haniniya. neighbour, n. makofchi (S.), makobchi, makubchi, pl. makofta, makochi (K.), makwabchi, pl. makwabta.

neighing, n. hanīniya.

neither, adv. $k o^{*}$; after a neg. neither...nor ko...ko.

nerve, n. jijiya, pl. jiwoji or jiyoji.

nerves, coll. n. dagura. nest, n. shẹka, sheka (S.), pl. shēkuna and shēkoki, gurbi.

net, n. taru, pl. taruna, marefiya (s.); spec. names for fishing-nets also răfa (S.), rāga, pl. ragogi, foma, homa (S.), koma; a n. used for carıying grass chali; the piece of wood to which the (foma) net is attached furnai.

nettle-tree, zuwo. network, n. aikin raga.

never, adv. expressed by v. tăba with negative, e.g. I n. acted thus ban tăba yin wannan $b a$; we $\mathrm{n}$. went there $b a$ mu tăba je nan ba; n. until now dadai with negative verb, e.g. I n. saw it dadai ban gani ba.

nevertheless,adv.saiko, tareda wannan, koda*, duk da hăka. new, adj. sābo, fem. sābuwa, pl. $s a b a b b i$ or $s a b b i$; a n. comer had̄ka; the n. moon sābon wata, farin wata; to make n. sabunta; making n. (renewing) sabunchi (K.), sabuntaka (S.).

news, coll. n. labāri, lkisa*; what is the news? ina labāri or ina labārin duniya? I heard n. of you na ji labārinka; to publish n. labarta; to spread false n. chinewa, kwarmăto.

next, adv. (as a qualification of nouns of time) gobe, e.g. n. month watan gobe; the $\mathrm{n}$. world lahira, gidan gobe; the n. day rana mai-zuwa or rana mai-zakuwa, kashegari (K.), wanshekare (S.).

nibbling, e.g. of ants, n. tausan (gara).

nice, adj. da dadi; something n. abin dadi. 
niche, alkuki.

nickname, lakabi, sunan wasa. Niger, Hausa name for the river; n. Kwāra, Kuwara or ruwan Kwara.

nigh, adv. kusa or da kusa; n. to kusa da or kusa ga.

night, n. dare; sabanin yana* ; all n. dare duka; at $\mathrm{n}$. or by n. da dare; good night! sanu da dare, sai da safe; last n. jiya da dare; it is n. dare ya $y i$ or duniya ta yi dare; to go by n. bin dare; to pass the n. wuni; when n. comes or came $d a$ dare ya yi; the n. overtook him dare ya yi masa.

nightjar, (Macrodipteryx macrodipterus) yaute, yotai, yautai.

nightshade, black n. gautan kaji.

nine, num. tar $\alpha$, n. hundred dari tara, by nines tara tara. nineteen, num. goma sha tara, sha tara, ishirin daya babu.

ninety, num. tisaïn, tasaïn, dari goma bus, dari gaira goma, the two last $=100$ less 10.

ninth, num. 1. ordinal na-tara, fem. ta-tara.

2. fractional n. tusu'i.

no, 1. interj. $a^{*}, a^{\prime} \alpha$.

2. adj. $b a b u, b a$, e.g. no money babu kurdi; no one babu kowa, ba kowa, babu wanda or $b a$ wanda.

no, to say, v. hăna, ki , kiya. nod, to, in assent, v. kăda kai, gyada kai.

noise, n. ămo, dŭmi, dimi, hayaniya, hāniya*, yagatu (K.), mita, holo; loud and angry n. hargowa; a vague unexplained n. burum; a distant n. $\ddot{j} i z \alpha$.

nomadic, adj. pl. masu-tashi. none, adj. babu (or ba) wanda, babu (or ba) kowa, babu, the last applied to things; $n$. used of persons babu mutum. nonsense, n. wawa, wawanchi; he talks n. shina magana barkatai.

noon, n. tsăkar rana.

noose, n. gen. zarge, pl. zarguna; spec. a n. for catching animals mazargi, azargagi, azazargi (S.) ; kiri, pl. kirra. nor, adv. ko with negative, e.g. he gave them neither bread n. money for bread $b a$ ya ba su ko gurasa ko kurdin gurasa.

north, n. arewa; on the n. or to the n. da arewa or arewachi.

northern, the, region, n. arewachi.

nose, n. hanchi; the bridge of 
the n. goral hanchi; the part of the $n$. between the nostrils zozon hanchi; a man with flattened n. mai-hanchi nanakke; to blow the $n$. fyache majina.

nostrils, n. hanchi, pl. hantuna. not, adv. $b a$, e.g. I know not ban sani; the $b a$ is placed before and after the verb or sentence which it negatives, e.g. I did not see the man ban gani mutum $b a$, or less correctly ban gani ba mutum; $b a b u$, e.g. it is not good $b a b u$ kyau; with imperative or subjunctive clauses kada, e.g. do not fear kada ka ji tsoro ; that you may not fall (or lest you fall) kada ka fadi; kada dai, e.g. let her n. be heard kada dai a ji ta; 'or not' when the words form the end of a question ko ba haka ba?

notch, n., e.g. in a tree for resting a load against loko.

note, v. $d u b a$ or $d u b o$, e.g. note this duba wannan.

nothing, n. $b \bar{a} b u, b \bar{a} b u$ komi, ba...komi or ba komi ba, e.g. who knew n. uanda bai san komi ba; n. but sai, sai dai. notwithstanding, adv. sai ko, tare da wannan, koda. nought, n., see nothing. novel, adj. 1. see new.
2. (strange) bakco, fem. bakuvva, pl. bakuna, baki or bakokuna, da baḳo.

novelty, n. (strangeness) bakonchi, bakontaka.

now, adv. yanzu, ko yanzu, lokachin nan; even n. ko yanzu, yanzu yanzu ; just n. yau yau; till n. har yanzu. nude, adj., see naked.

nullah, n. ķorama, njere*, injere*.

numb, to be, v., see numbness.

number, n. gŭda, lisafi; five in n. gŭda biyar; without n., beyond n., is expressed by fi kidaya, e.g. fishes without n. kifaye su fi kiidaya.

number, tr. v. lisafi, ḷilga or kirga.

numbering, method of, $\mathbf{n}$. kidaya, kididdiga.

numbness, n. dela, my hands are numb dela ya kama hannuwana, lit. n. has seized my hands.

numeral adverbs, these are formed by prefixing sau, so or guda to the cardinal numbers, e.g. once sau daya, thrice sau $u k u$ or guda uku. numerous, adj., see many.

nurse, n. mai-reno, mareniya, majiya*.

nurse, tr. v. rene. 
nursing, n. reno.

nut, n. kualo, kwaluu a, givchi

(S.), the small edible groundn. called also the monkey-n. gyada (S.), gĕda (K.), gujiya (S.), pl. gujeye, monkey-n. oil main gyada; Bambarra ground-n. (Voandzeia) kwaruru, gujiya, this n. when roasted is called yaro da dariya; kola-n. goro q.v.; hazel-n. $\quad \operatorname{chan} \approx a^{*}$, anza*; shea-n. kadanya; tiger-n. aya; physic or purging $\mathrm{n}$. bi ni da zugu; see also hawayen zaki; the inside of a small ground-n. which resemblesin colour that of a bidi (roan) horse, bidi; a driedup n. kauda, koda.

O ! interj. ya, af, «sha, ap. oak, i.e. African o., n. guvinki*, namijin kadanya.

oath, n. rantsuua, safirchi*; to take an o. rantse and yin rantsuwa; a common oath is wallahi, i.e. by Allah !

oats, wild o. bunsurun daji.

obduracy, n. taurin zuchiya, matauriyar zuchiya.

obdurate, adj. da trurin $\approx u$ chiya.

obedience, n. da'a, fisa'a (K.). obedient, cf. he is disobedient ba shi da'a. obeisance, do, v. yin sujada, runsuna, rusuna, yin afi, he did o. to him ya yi masa afi. obey, tr. v. $b i, j i$; to o. a command kiyaye magana, also $b i$ (or ji) magana.

object, n. abu, e.g. a wonderful o. abin mamaki; a delightful o. abin murna; a sad o. abin tausayi.

object, tr. v. ki; to o. to labour etc. yin kivurya (or қyuya); to o. to an agreement walwale.

objection, n. livwuya, makanyara.

obligatory, lazumtache, see necessary.

obliterate, tr. v., see blot out. observance, religious, n. ada. observe, tr. v. 1. see notice.

2. (to comply with, e.g. the commandments of God) rike, rika, riki; to o. a promise damre magana, chika magana, kula bisa magana. obstinacy, n. kin jii, shishige, taurin kai.

obstinate, adj. mai-kin ji, he became more o. ya kara shishigi.

obtain, tr. v. same, sami, samo, riske, riski, ruska, chi*. obtained, to be, v. samu*. obvious, adj. zahiri. occasion, n. (time of an 
occurrence) loto, lotu, lauto (S.), lokachi*.

occupation, n. 1. (a being occupied or busied) shagali, safara (S.), e.g. the occupations of this world $\operatorname{sh} \alpha$ galin duniya.

2. (a trade, profession etc.) gwani*, sana'a, anneshuwa. occupied, to be yin safara. odd, adj. 1. (strange) bako.

2. (uneven) mara; even or o. chǐka ko mara.

odour, n. wari, wardi, frequently of a bad, disagreeable odour, so also doyi, dwai (S.); an agreeable or sweet o. kamshi; concr. a thing producing an agreeable o. or scent abin lamshi; to get or emit a bad o. zaman wari, yin wari, ruba or riba ; to perceive such an o.jinwari. oesophagus, garera, jannai (S.).

of, prep. (genitive) $n a$, fem. $t a$; also expressed by the connective forms in $-n$, fem. $-r$, $-l$; e.g. history of the kings labari na sarakuna or labarin sarakuna. The genitive relation is often expressed by the addition of a possessive pronoun, thus, the house of the king gidan sariki or sometimes sariki gidansa. off, adv., e.g. far off, at a distance off daga nesa; to be 0 . (to depart) tafi; to come o. (to happen) faru; to go 0 . (to escape) fiche, tsira, gudu*; be o.! arr.

offence, n. 1. (displeasure) haushi; to feel o. jin haushi.

2. (transgression, sin) zam$b a$ or $z a n b a, z u n u f i$ or $z u n u b i$, pl. zunufai.

3. (an annoyance) alale, abin alale.

offend, tr. v. 1. (to commit a transgression) yin zamba, yin zunufi.

2. (to annoy) alale. offer, in bargaining, to make an, v. taya, yin tayi; an o. is made an taya.

officer, 11. zarumi, zaromi, zarmi or jarumi, pl. zarumai; spec. o. at court turaki, bafada.

officers, n., a king's o. fadawa, q.v. ; spec. one of the chief o. ma'aji; for non-commissioned o. in English employ masu-igiya (i.e. bearers of stripes) is used.

official, n. galadima*.

offspring, n. diya, iri, pl. irare, zuriya, zuri'a.

often, adv. sau tari, sau dayawa.

oil, n. mai; any dark o. ala- 
yadi ; spec. castor o. main zurma; 0 . from ground or monkey-nut main gyada; o. from the kwākwa palm main $j a$, alayadi; o. obtained by distillation from sesamum seed (cf. samsam) main ridi; o. from the seeds of the sheabutter tree main kadanya; meni o. tree mamijin kadan$y a$; a large fish from which o. for eating is obtained gini, shambăna (S.), zau; o. palm kwakwa, gima (S.).

oily, to be or become näshe, $n \bar{a} s h i$.

ointment, n. main shafewa, jibda.

okra, (plant) kubewa.

old, adj. tsofo, fem. tsofuwa, pl. tsoffi, tsofaffi, tsofoffi; o. age tsufa; to grow o. tsofa, tsofe, tsufa and yin tsufa; he is o. yayinsa ya wuche; an o. man with bent back takoko; o. woman gyatuma, jatuma ; to be older than girme; 0 . clothes ragga, pl. ragguna; to make o. (i.e. to wear out) tsofe; see aged.

old, of, adv. dā and lokachin $d \bar{a}$; as of o. kaman na $d \bar{a}$.

olden, in...time, adv. phr., see prec.

olive, tree, n. zaiti*.

on, prep. bisa and $a$ bisa, e.g. o. a horse bisa doki; o. a hill a bisa tudu.

once, adv. sau daya; to do a thing o. taba, e.g. I saw him o. na taba ganinsa; at o. (forthwith), I will go at 0 . zan rika tafiya; o. (in former times) lokachin $d \bar{a}$; in a weaker sense (on one occasion), e.g. there was o. a man mutum ke nan or akwai wani mutum.

one, num. adj. daya; o. of you dayanku; o. another junansu; o. at a time daya daya; o. here o. there daya daya; not even o. (in negative sentence) ko daya; but o. sai daya; o. (i.e. French 'on' used as a prefix to verbs to form a kind of passive voice) $a$.

oneself, periphr. for, refl. pron. zuchiya, see self.

onion, n. albăsa, pl. albăsoshi; wild o. habki; spring o. albăsa mai-kŭnne, safa*; spec. onions cooked in soup taushi, taushe; leaves of onions lawashi.

only, adj. and adv. makadaichi, mukadaichi, kadai, sai, sai dai, kawai, kauwe or kauwi, e.g. he only shi makadaichi or shi kadai; there was nothing in it, stones o. babu 
chikinta sai duuatsu; you have $o$. to stretch out your hand and take it sai dai ka mika hannunka ka karḅa ta ; my o. brother gřda ḳanena.

onwards, adv. gaba; to go o. (to advance) yin gaba, chin gaba. ooze, intr. v., also to o. out, $z u b a, z u b o$.

open, adj. (i.e. unabashed) kirikiri; an o. place sarari ; come out into the o. futo sarari.

open, to be, intr. v. budu; the way is o. an shika hanya or hanya ta budu; cf. seq.

open, tr. v. buda, budi, bude, fuda, huda, wari; to o. by making a hole in anything fuda or huda; to o. wide bubbude; to o. out fida or fide, e.g. of unfolding a standard; o. the umbrella yaye lema; to o. by untying bale.

opened, particip. budadde, fem. budadda, pl. budaddu, also expressed by the pass. form a bude; to be o. fudu, e.g. when all the gates were 0 . lokachin da dukan lofofi am bude su.

opening, n. (aperture) budi, baki, pl. bakuna; (hole) bariya; (commencement) firrausa; the act of o. budawa, fudawa. openly, adv. a bude, a sarari, fai.

ophthalmia, ămōdari.

opinion, in my o. abin da na gani, a tsamanina.

opponent, n. abokin-yāba, see enemy.

opportunity, n. dama, zarafi, zarahi, sukuni (S.), e.g. he had not the o. $b a$ ya samu dama; I have o. to ina da zarafi; God give thee a favourable o. Allah ya ba ka $s a^{\prime} a$; if I get an o. idan $n a$ samu sarari.

oppose, v. hana, kara, karo, yin karo, see conflict.

oppress, tr. v. tsane, tsani, tsananche.

oppressed, particip. adj. maḳasḳachi, mai-ḳasḳasta, ł̣askastache.

oppression, n. alhaki, tono, yaji.

option, o. of sale chinikin zabi. or, conj. ko. The correlatives either...or ko...ko.

orb, n. guda*, its o. gudanta. orchid, manta uwa, muruchin bisa.

ordeal, by water, n. gwaska. order, n. 1. (custom, rule or method of procedure) ada, tada, al'ada.

2. (a command) hakumchi, hukumchi, dolashi. 
3. adv. phr. in o. (in good order, correct) daidai; conj. in o. that domin, don, in, har dai, a brsa, e.g. he took medicine in o. that he might be cured ya sha magani domin a warke shi (or shi warke) ; in o. that not domin $k \check{c} d a$, e.g. let us take great care in o. that we may not miss the way mu tunane kwarai domin kăda mu rasa hanya; in o. to garin, e.g. you and I will go out in o. to take a walk ni da kai za mu tafi yarin yawo.

order, v. hăkumta, hăkumche, hukumche, yin umarni, kudarta; the last used of God. ordered, particip. (arranged) shiriyayye, fem. shiriyayya, pl. shiriyayyu.

orderly, an maji-kira, majiyakira.

ordinance, n. shari'a. ordure, n. kashi; see dung. ore, iron, n. tama.

oribi (antelope), batsiya.

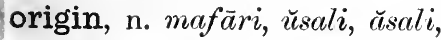
sabili, tisshiya, e.g. the o. of a fable or story, i.e. what the fable explains or accounts for dalili; their $o$. is the same tushiyarsa daia.

orion, (the constellation) $m a$ halbi. ornament, n. 1. abstr. (embellishment) $a d o$, e.g. for o. na ado. 2. concr. ornaments kayan ado.

ormamental, adj. na ado. orphan, n. marāya, fem. marainiya, pl.marāyu; orphans, i.e. children whose parents died soon after their birth who have been entrusted to strangers to bring up dangana. orphanhood, maraicli.

oryx, n. mariri, marili; white o. walwaji, warwaji.

ostentation, fäde.

ostrich, n. jimina, pl. jiminu. other, pronominal adj. 1. (different) dabam, daban; 0 . words maganganu dabam.

2. correlatives, the o. wanchan, fem. wachan, pl. wadannan; less emphatic of various members of a group, e.g. the one...theo.,pl. some... other's wani, fem. wata, pl. wansu, wasu or wadansu repeated, e.g. the one said yes the o. said no, quarrelling urani ya che $i$ wani ya che a'a sunc yin gardama.

3. o. than (equivalent to Engl. else) sai, this is seldom used except in negative statements, e.g. nothing other than blood sai jini; bamda, e.g. we have nothing o. than 
this ba mu da komi bamda wannan; see another.

otter, African clawless o. karen ruwa.

ought, aux. v. 1. (personal construction) wajaba, wajiba, e.g. we o. to repent mu wajaba tuba.

2. (impersonal constr.) kŭmata, kămache, wajiba, e.g. ya wajiba mu tuba or ya kămata mu tuba; wajib or wajibi is used with the v. to be, e.g. wajibi ne (or ke) mu tuba.

ounce, an o. weight wakiya*, wukiya*.

our, poss. pron. 1. suffixed -mu or $-n m u$, e.g. o. relations danginmu.

2. separate, when obj. possessed is masc. namu, when fem. tamu; thus, o. horse doki namu, o. mare godiya tamu.

ourselves, refl. pron., see self. out, adv. waje, e.g. he has gone o. ya tafi waje; the fire has gone o. wuta ta mutu; o. of dăga, e.g. he took a stone o. of his pocket ya fitas da dutsi daga aljifunsa; to go o. or to put o. (used of a fire) biche.

outcry, rakadi, suwa suwa, see cry. outdo, tr. v. (surpass) $f$, faye. outrun, tr. v. rŭgaya, řga, tsēre, tsire.

outside, adv. a waje, waje and daga waje; 0. the town bayan birni.

outward, adv. daga waje.

oven, n., i.e. a pit for cooking bread in tanda (S.), tanderu (K.).

over, adv. (left, remaining) to be o. wanza and wanzu, saura, what is o., n. burbish $i$; to be o. (to be finished) kare ; o. and above, prepositional phr. bamda; o., prep. bisa, a bisa, with or without $g a$, e.g. he fell o. a big $\log$ ya facli bisa babban itache, he spread his gown o. the stones ya shimfida rigassa bisa ya duwatsu.

overcharge, n. (an excessive price) kūra.

overcharge, v. (to charge an excessive price) shirga with tsada (dear), e.g. he overcharges yana shirga tsada. overcome, tr. v. rinjāya, rinjayi, rinjaye, faskare, kāda, $k \bar{a} s h e, i m a, i$; sleep overcomes me berchi ya kama ni; see overpower. overdo, to shirga. over-eat, to ginsu, gundura, gumde*. 
overflow, intr. v. (of rivers) yin gibi.

overflowing, used of a measure amaiche.

overpower, tr. v. kāshe, gagara, buwaye; he overpowered ne ya buwaye ni.

overpowering, vinjaya.

oversee, to wakilta.

overshadow, to inuwantad da. overstep, to swaḅa, săḅa.

overtake, tr. v. tăras da, tsare, ishe, iske, chi ma, kwarari, kwarare.

overthrow, n. kaye, pl. kayoyi. overthrow, tr. v. birkichi, birkiche; giche or gichi; jirkita, jirkiche ; hankada, jefas da (K.), jefad da (S.), jefashe (Zanf.).

overturn, tr. v. tankade, kāshe, kade, juya; the latter used with $d a$.

overwhelm, to yin kaye; see overthrow.

owe, tr. v. hăda hannu da, also expressed by n. bashi (debt), e.g. I o. him ina da bashinsa (lit. I have his debt); he owes me shina da bashina; see debt.

owl, n. mujiya, pl. mujiyai.

own, tr. v. expressed by ga or with pronouns gare, the pres. form in $n a$ with $d a$; $k e$, fem. che with $d a$; and by the forms in mai-, e.g. I o. the horse doki gare ni, ina da doki, ni ke da doki or ni ne mai-doki.

own, adj., e.g. my o. nawa, with fem. obj. tawa; cf. H. G. p. 24 .

owner, n. mai-chi, mai-abu, connective form mai-abin; the forms in mai-frequently express ownership, e.g. house o. mai-gida; o. of a boat mai-jirigi.

ox, n. sa, pl. shanu; hurtumi, pl. lurtumai; o. with red body and white face buli; pack o. with wide spreading horns takarkari, pl. takarikarai; hole in nose of an 0. azirka, zari (S.).

ox-pecker (bird), charki, tsarki.

oyster, freshwater o. makankari, kawa.

pace, a $t \bar{a} k i$, pl. tāke-tāke, tākitīki.

pack, tied up, n. rizuma.

pack, up, to, tr. v. (e.g. a load) lapta, labda.

package, n. kaya, pl. kayayeki. packet (e.g. of paper), n. rizuma, risma.

pack-saddle, n. sirdi, shirdi, pl. siradi, sirduna, sirida, siridda or sirada. 
pad, n. (placed on dinkey) lāheru, leferu, lafero, akumari; (on head of carriers) gamo, ganwo, matsetsi; a p. at the back of a camel's saddle sulăki.

paddle, tr. v. tunkuda (or tūka), jirigi.

paddle, fito, used as a rudder, n. matuki.

paddles, coll. karoki, p. of a canoe fulafule(S.), filafili(S.), pilapili (K.).

paddling, participial n. tukawa.

pagan, n. arne, pl. asna or arna; in a less strict sense (unbeliever) kafiri, pl. kafirai or kafirawa.

paganism, n. addini na (asna or) arna or addinin asna, kafirchi; to fall back from Islam to $\mathrm{p}$. rinda.

page, of a book, n. warka, warakia, tabaka, taba'al takarda, shafi, shafe.

pain, n. zafi, azāa $b a$, alala, arkăne, kiñda, masība, wahala, jitsa, marwa, radadi (K.), harbawa, zogi; labour pains wahalar haifuwa; to feel p. jin zafi, jin arkăne, shagi*. pain, tr. v., to cause p. azabta. painful, adj. da zafi, da wuya, $d a$ zogi, mai-radadi (K.). paint, to š̆fata, š̆fache, zīna. pair, a wari.

palace, royal, n. $f \bar{a} d a$, pl. $f a-$ dodi, dandalin sariki.

palate, n. dābori, dāburi.

palaver, n. kuchi, pl. kuchekuche, alămari, shawara*.

Palestine, sham*. palisade, kāwara.

palm, of hand, n. tăfin hannu. palm, n. (the tree) deleb, fan or Palmyra p. giginya, pl. gigangani, giginyoyi or giginai, kări*, the dum p. goriba, pl. goribai, goribobi; fronds of dum p. kăba; the oil p. kwākwa, gima (S.); flowers of a young p. tree kilili; wine p. tukuruwa; a bag made from leaves of the last kororo; nut of the giginya p. kodago (S.), kxurdugo; p. leaves tsaiwa; p. oil main $j a$; p. wine from the tukuruwa p. bam, bambi, bammi; a species of $p$. from leaves of which hats and mats are made kajinjiri ; beams made from the fan p. kwangi; cocoa-nut p. kwakwan attagara; the ball-like fruit of the fan or deleb palm klwǒlo; the unripe fruit of this $p$. is called kwalshini (S.), shoots of the fan p. used as a vegetable murichi, muruchi.

palsy, inna. 
pan, cooking, brass, with handle, n. algidari, alkidari. pangolin, see manis.

panic, n. (sudden terror) tunzuruwa, tunzura, razana, champi.

pannier, grass, n. gufi, gufatı, adīla.

pant, intr. v. yin sheda, shesheka.

panther, rabji*, rabbi*, dumisa*.

panting, n. luăki (S.), shashaki. pap, n. (of the breast) nono, pl. nonna, nonnaye.

oapaw, n., see pawpaw.

paper, n. takarda, pl. takardu ; a p. (a document) laya; a sheet of p. taba'al takarda.

oarable, n. misali*, almara; to speak in parables yin misali, kuratamta, kwatantr.

baradise, n. aljanna.

oaragraph, of the Koran, $n$. izufi.

oarakeet, (Agapornis pullaria) tsiriya; see love-bird?

parallel, that which is, or like, adj. mai-maki.

oarallel, to make, tr. v. daidaita.

paralysis, inna.

jaramour, kwcerto.

sarasite, n. (a hanger on at other's' tables) mai-kwaraka. parch, tr. v. surya, soya, suya. parched, particip. soyayye, fem. soyayya, pl. soyayyı. pardon, n. gafara.

pardon, tr. v. gafarta, yafe; as a polite expr. I beg your

p. (excuse me) gafara or $k a$ gafarta ma ni.

parent, n. mahaifi, pl. mahaifa.

parents, n. uwaye, iyaye, bafayu ; cf. also prec.

parrot, n. aku, jiljilmako. part, n. rabi, rabo or rabu, pl. raberabe, wari, shashi, sashe (S.), e.g. each of them shall receive his p. kowannensu zai samu rabonsa; (region) waje, pl. vajeje.

part, tr. v. (to separate) raba. parting, n. rabuuca, rabo. partition, n. (i.e. wall) shomaki, pl. shamakai.

partner, n. abokin taraiyn. partnership, karo, cf. kurdin chaffa (or chappa) the fees paid on the establishment of a partnership.

partridge, red-legged, n. mokurva, makucurua, fakăro, pakăra.

parts, which make up a whole jimilla.

paschal lamb or ram, $n$. rayon laya.

pass, $v$ wuche, fiuche; to p. 
anyone on the path goche or guabche; to p. the night kwana; kwanta, wuni; to p. away shude, shuda, shudi, wuche or fuche; to p. by wulga, wulge, wurga, wuche, fuche, zāge, zuāge (S.), zāa $a, z \bar{a} g i$; to $\mathrm{p}$. near gege; p. on! ku shige; to p. over (to cross) ketare, (to skip words in book) ratsa chingara.

passage, a mashigi.

passionateness, n. harāra.

passover, feast corresponding with, n. sallal laya.

past, the, n. (former times) $d \bar{a}$, baya, e.g. the wars of the p. yakoki na $d \bar{a}$; the things of the p. abubuwa na-baya; a thing p. abin baya.

pastor, n. (shepherd) makiyayi or makyayi, pl. makyaya.

pasture ground, n. uurin kiwo, makiyaya.

pasture, v. tr. and intr. (to graze) kiwo.

patch, n. banke, shafi, fito, shiga, pl. shiguna.

patch, tr. v. (of cloth, clothes) banke, toshe, shafi, shafe.

path, n. turba, pl. turbobi, harya, hayya, haya, pl. hareyoyi, tafarki, pl. tafarkoki, godabe; a straight p. hanya sosai; a narrow p. labi; fig. the $p$. of religion or conduct hanya or tafarki, e.g. the paths of Mussulmans hanyoyin musulmi.

patience, n. hankuri, hakuri, hakurchi, hankura or hakura, dangana; a man of extraordinary p. rakumin Allah; to show p. (to be patient) yin or the forms ending in -na followed by harkeuri, e.g. they have p. suna yin hankuri or suna hankuri.

patient, 1. adj. (calm, not fretful) $d a$ hankuri, maihankuri, mai-haḳurchi, da sanyin rai; to be p. jimvi, juri, hanķŭra, yin hankuri; he is p. towards everyone ba shi l.osawa da mutane; cf. prec.

2. n. (a sick person) maraslafiya*.

patois, (i.e. bad Hausa) băbauchi, baubauchi.

pattern, a p., e.g. in cloth zane. paw, dagi.

pawn, to yin ramche.

pawpaw, n., i.e. both the tree and the fruit gwarida, gwadda (S.).

pay, n. lada, biya, e.g. that is their p. ladansu ke nan; 8 soldier's deferred p. kurdin huji.

pay, tr. v. biya, yika, rama; the last is also used in the senst 
of to requite and to reward; to p. a debt biya basli $;$; to p. a second time or over again kwatamtawa.

bayment, n. biya, lada. sea, earth p. kwaruru, kwaIulu, gyada; pigeon p. (Indian dhal) waken turawa; heart p. gautan kwado.

peace, n. lafiya, limāna, natsu, natsuwa, wāli, pl. wale-wale; there is p. between us lafiya tsakanin mu; you can travel in p. kana iya yin tafiya da lafiya; p. of mind dadin zuchiya; p.! (a salutation) sallama; to be at p. yin wāli.

beace-maker, n. matsakanche, maitsakanta husuma.

seak, n. kai, e.g. p. of a hill kan tudu; spec. p. of a saddle kwachiya; the front p. of a saddle kwachiyar yaba; its hind p. kuachiyar baya. seal, of thunder, n. trawa. searl, n. murjan*; idon zaura; pearls coll. Kuan kifi. jeck, tr. v. koto.

seculiarity, n. (of animate beings) hăli, pl. hălaye.

seddler, mai-sari.

peel, n. (of fruits, etc.) kwasfa, kosfa*, pl. kwasfofi, bawo, tsiyayi.

seel, v. 1. tr. kware, kwari, bāra, bāre, bambaro, konkole, kualkwale, kankari, feke (S.), fere (K.).

2 . intr. to p. or p. off, as the skin from a blister sale, socule, swale; it peeled off ya laru.

peep, to leka, leki, leḳo, rēga (S.), see spy.

peering, p. into rego (S.).

peg, n. maratayi.

pelican, n. kucasakuasa, jinjimi* ; a short-legged p. bubukunua (S.).

pelt, to, with, tr. v. jejefi da, jajjefa $d a$; to p. with stones jefa da duwatsu.

pen, n. 1. (for writing) alkalami, pl. alkalamai.

2. (enclosure for sheep, etc.) garke, pl. garkuna, turke, rugga, yarge (S.).

penalty, jaraba.

pendant, e.g. a p. stone worn

by women, n. talhatina, pl. talhatinu.

penis, azakari, bura, didi, kutuma, mazakuta, (of animals) gandari, talolo (K.).

pennisetum, n. (Cenchrus catharticus) karangiya; cf. yero, maiwa.

people, n. mutane, pl. of mutum (in the sense of population and persons generally), e.g. the p. of Lingi mutanen 
Lingi ; (connections, relations, etc.) kibanta*; (followers, congregation, etc.) al'umma.

pepper, n., red or chilli 1 . barkono; a large green $\mathrm{p}$. tatasai, twashshi, tushi; spec. a red p. (capsicum) kǒle, tankwa, tsidifu; Melegueta p. or 'grains of paradise' chitta; African, Guinea, or negro p. kimba; West African black p. masoro; the hotness or sharpness of $p$. yaji, pl. уаzиzzйka.

peradventure, ads. watakila, halama.

perceive, tr. v. 1. gen. (to apprehend by the senses) $j i$; to p. by sight gani.

2. (of comprehending, understanding) fahimta, $j i$, also sani; to p. something wrong farga, e.g. I p. that you are cheating me na farga da kai.

percolate, to yoya, see leak. perfect, adj. ingatachi.

perfect, tr. v. chika.

perforate, tr. v. fuda or huda, sossoke, sosoke; see pierce. perforce, adv. tilas, da tilas, e.g. we had to go on board p. mun hawa bisa jirigi da tilas; see force. perfume, n., see odour. perhaps, adv, watakila, halama peril, n. hatsari.

perish, intr. v. (to be spoiled, wasted or destroyed in any way) bata, bache, yakuche, e.g. they p. together sum bache tare, lalache, mache; (to die) mutu, e.g. they perished of hunger sun mutu da yunwa. perished, participial adj. lala

tachche, fem. lalatachchiya:

pl. lalatattu.

perishing, participial n. lala chewa.

perjury, n. kapara, kafara (S.)

to commit p. (to swear falsely' yin kapara.

permanence, n. tabbataua. permanent, adj. matabbata

to make p. tuturta.

permission, n. yarji, yardi

yarda, izni, e.g. grant me p ba ni yarji; by the p. of Gor da yardan Allah or bisa yar dan Allah.

permit, tr. v., see allow. perplex, to dāme, dāma; set confuse.

perplexed, to be, intr. $r$

dāmu.

perplexity, n. tunzura.

perquisite, a corn-dealer's $p$

rara.

persist, to zage*, dora*. persistence, nāchi, nachiya see continuance. 
person, n. mutum, pl. mutane, also (with or without mutum) wani, fem. wata, pl. wansu, vasu, vadansu, yasu, e.g. some persons wadansa mutane or uadansu; a certain p. who shall be nameless mutum kaza.

oerspiration, n. jŭbi, gumi, zufa.

oerspire, intr. v. yin jübi, zufa, yin gumi.

oersuade, tr. v. lallasa, biko, füra kunne, kŭta.

persuaded, particip. pass. (sure or certain) is expressed by means of tabbata, etc., e.g. he was p. that...ya tabbata. persuasion, lallashi, pl. lallasoshi.

pervert, tr. v. (to lead from truth or right) rude.

perverted, part. pass. (misled) rudadde, fem. rudadda, pl. rudaddu; to be p. rudu.

pestilence, n. alloba, aloba, bala' $i^{*}$.

pestle, n. kayan dăka, taḅariya, pl. tabare.

pet, (favourite) dan tatangi.

pheasant, crow p. or lark-heel cuckoo ragon maza; rock $\mathrm{p}$. kazan dutsi.

phoenix bird, fufunda*. physic, n. (medicine) magani, pl. mayunguna. physician, n. mai-magani, pl. masu-magani; see doctor. pick, n. dundurusu, kalme. pick, tr. r. (to choose) zabe, $z a l y a$ or zabi ; to p. a quarrel tona fada; to p. out tsina, tsinche, tsunche and tsinta, kwalkwale, konkole, ḳwakule; to p. up jüle, sarbe; to p. the teeth kwakwala, hakori, sakata hakori.

pickaback, (a children's game) dokin wuya.

picked, part. pass. (chosen) zababbe, fem. zababba, pl. zaluabbu.

picking a thing off the ground, particip. n. tsintura, tsuntuwa.

pick-pockèt, dan sāne.

picture, n. misali*, kăma* ; his p. misalinesa or $k a$ mansa.

piece, n. wari, bangori; small p. of anything tsibiri, chibiri or chibri, gutsure, pl. gutsatsari, tarfi, guntu, gutsi; a small fragment guntun $a b u$; to break a p. off gutsuri.

pieces, to tear to, tr. v. tsatstsaga.

pierce, tr. v. fuda, huda, huji, soka, soke, soki, yin sakiya, tüne, zarta; intensives, to $\mathrm{p}$. many holes fufuji, furfuje, 
huhuda; to p. through sossoke.

piercing, n., e.g. of the skin by an arrow sakiya, soka, pl. soke-soke.

pig, gursunu, pl. gursuna, ala$d e^{*}$; wild $\mathrm{p}$. and red river hog aladin daji, durungu; wart hog gyado, gadu, fem. gadoniya, pl. gyadodi, gyaduna, alhanzir, mugun dăwa, rishi. pigeon, n. tantabara, pl. tantabaru; fruit p. or green p. biribiri or kurchiyar gamji, see dove.

pike, n. (spear) mashi, pl. masussuka or masu.

pile, n. (heap) taru or taro, pl. tarori.

pile up, tr. v. tàra, tattāra, hăda, tǔla.

piles, kūrga (K.), basur*.

pilfer, v. sata, yin sata, sache, see steal.

pilferer, n. mai-sata.

pilgrim, n. hăji, hajji (S.), pl. hajoji.

pilgrimage, n. haji; to go on the p. haji and tafi haji, ziyarta.

pill, n. chibiri* or chibri* pillage, n. (booty) abin ḳwache. pillage, tr. v. kwache, e.g. he conquered them, he pillaged their property ya chi su ya $k$ uache dukiyansu. pillar, n. gimshiki, gumshiki*, pl. gimshikai.

pillow, n. matashin kai, majingini.

pimple, bar-ni-da-mugu.

pin, n. $t s i k o^{*}, t s i n k e^{*}$; a p.

used for pressing cotton dan $b \check{d} d a$; a large wooden $\mathrm{p}$. used in winding the thread on the cylinder which is fixed in the shuttle tangori.

pincers, n. kwāguwa, hantsaki, madebin ķaya*.

pinch of, to take, v. tsakurra, gutsura.

pinch, tr. v. tsamuka, tsakura*, tsamka*, tsungule, yin ķwanta, muntsini.

pinching, n. kwanta, tsamuki. pinnacle, n. kokuwa, kokowa. pipe, tobacco-, n. tukunyar taba, lofin taba.

pistol, n. akotiya, algaderiya. pit, n. rami, rame (S.), pl. ramuna or ramu, ganwa; spec. a deep wide p. hangarma*, kwări* ; p. for cooking bread in tanda or tan deru; p. for storing corn tsunjiya; p. for game to fall into hăko, pl. hăkōki a cesspit salga, pl. salgagi; dye-p. marina, pl. marinnai.

pitch, tr. v. 1. (to cast, throw) jefa. 
$\div 2$ spec. to p. a tent kăfa lema (or laima).

sitcher, n. tulu, pl. tuluna, tukunya, pl. tukwane, tukane; randa, pl. randuna; a $\mathrm{p}$. with a narrow mouth dan tozo.

pitfall, n. hako, pl. hakoki.

pity, n. tausai, tausayi, juyaye, sauna; to have or feel $\mathrm{p}$. yin (or jin) tausai, jụka; what a p.! abin tausayi, tazanko, tanzanko.

oity, tr. v., cf. prec.

olace, n. wuri, pl. wurare; waje, pl. wajeje, bigëri, bige, bigi; (district, country) gari; an uninhabited p. dăwa; in circumlocution to supply the want of various special nouns and adjectives, e.g. a p. to flee to (refuge) wurrin gudu; so also gida, e.g. p. or abode of pain gidan $a z a b a$; a secret p. lolokin asiri; in that p. wurinnan, a würin nan, dăga nan, e.g. there are many hippopotami in that p. akwai dorinnai dayawa daga nan; in p. of (instead of), e.g. in his place gurbinsa, bigerinsa, wurinsa; the last also $=$ at his p., i.e. near him, with him ; to give $\mathrm{p}$. to, let him take the p. of another shi koma matsayin wani; an- other was put in his p. an $s a$ waniwurinsa; to take p. faru. place, nouns of, these are formed by means of prefix ma-, e.g. hiding p. maboya, kitchen madafa, inn mashidi from boya, dafa, shida respectively.

place, tr. v. sa, sanya, kăfa, aje, which denotes also to p. aside, dor $a$, aza or aza ma; to p. on, e.g. he placed me on the camel ya dora ni bisa ga rakumi; to p. on the ground (e.g. a load) jǔbe, jefo*, kasa; to p. together (e.g. for the purpose of comparison) kwatanchi; to give p. kau.

placing, of a thing, participial n. sawa; p. one thing upon another rĭbiye.

plague, n. 1. (pestilential disease) alloba, dawainiya, rangăza; 'he caught the p.' turn by 'the p. caught him' alloba ta kama shi (or same shi).

2. (an annoyance) alale, wahala.

plague, tr. v. (to vex) wahalshe, dawainiyas da; see annoy. plain, n. fili, pl. filaye, sarari, karkara, pl. karkarori or karkaroni, kanga; the battle p. kangan fada. 
plain, adj. (of language simple and open) a sărāri.

plait, tr. v. tubka, tufka, tupka, tukka, tumka (S.), yin kitso. plaiting, sāka; p. of mats sākar zana; (of hair) doka, kitso; p. of hair in two lines jaki; hasty p. of woman's hair kumbuchi.

plaits, coll. n. kaikainya, (of woman's hair) bijaji, bujibuji, biji-biji.

plan, n. (scheme, device) wayo, vayau, dabara.

plank, n. faskare, gungume, pl. gungumai, rumfia, pl. rumfuna, kange**.

planks, to make into, v. yin faskare.

plant, tr. v. 1. (to set or sow in the ground) shibka, shipka, shuka, yin shibka, dăsa, dashi, dashe.

2. (to set or place) sa, e.g. there was no place to p. our footsteps babu wurin da mu sa matakai bisa.

plant, n., i.e. a cutting dasashe. plantain, n. ayaba applied both to tree and fruit, also used to denote the banana.

\section{planter, n. manomi.}

planting, of seeds, n. biso.

plants, small, coll. n. shibka, shipka, shuka.

plaster, tr. v. (of walls etc.) yāba, yābe, dampara, damfara; (of floors) mamari.

plastered, participial adj. yabaḅbe, fem. yabaḅba, pl. yababbu.

plastering, yāạe, pl. yā be-yābẹe. plate, n. tangaram, tangaran; a p. made of plaited grass taitai, pl. taitaye; see dish. play, n. (the doing of anything for amusement) wargi, gyauga*, wasa; hail to you at your p. (salutation to persons at p.) sanunku da uargi.

play, v. (of sport, amusement) yin wargi; (of music) yin wasa, yin kidi; the last particularly applied to instruments struck or beaten. player, on drum, n. makidi. playing, n. (of amusement) wargi, gyauga*; (of music and especially drumming) kida or kidi, molo, pl. moluna.

plaything, n. abin wargi; spec. p. made from a seed pod kachau-kachau; see rattle. pleasant, adj. mai-dadi, da dadi.

please, tr. v. sa dadi, yama, gamshe, e.g. it pleases me ya game ni or ya gamshe ni; $\mathrm{p}$. (elliptical $=$ if you p.) mana e.g. come here, p. zo mana 
p. (i.e. allow me) bari; p. do yarje mana.

leased, to feel, intr. v. jin dadi.

leasure, n. (agreeable sensation or emotion) dadi, ni'ima ; (a gratification) abin dadi, abin murna.

ledge, n. jingina, dangana ; p. held for money owing kamuwa*.

ledge, tr. v. (to leave anything as a p.) jingina, tolma. Pleiades, pr. n. tarsowa.

lentiful, to be p. yalwata.

lentifully, adv. tari, kainnain*.

lenty, n. yawa, dayawa, kari, tari, tuli, băro, dumbuje, malala, tinjim, e.g. p. of words yawan magana or magana dayawa; p. to eat zari, zwari, an chiya*

liancy, rauni*.

lot, n. wayo, wayau, to form a p. gama.

lot, v., to p. together damra dabāra.

lough, n., spec. a large hoe bent back like a small $p$. galma (S.), garma (K.).

lough, to fuda, huda, kafche, kabche.

lover, a kind of, n. kyarekyare, zakaran yaki, zakaran assuba, dan raguwa; black-

R. H. D. headed p. or 'Niger bird' or 'crocodile bird' ladin kogi, jakin gulbi (S.).

pluck, tr. v. chira, chire, chiro or tsira, tsire, tsiro, dèbe, dïba, lēbo, tuge, tumbuke, zumbuke (S.); (to p. fruit etc.) tsinki, tsunke, tsinko, tsīge, tsitsige; (to p., e.g. a fowl) f'ìge, fìgi, piga, tuza; to p. out yin dono; plucked figagge, fem. figaggiya, pl. figaggu.

plucking, n. fìga.

plum, n., gingerbread p. gawasa, pl. gawasai, gawasuna and gawasoshi; hog, Spanish or Jamaica p. tsadal lamarudu; a tree with plum-like fruit danya, loda (S.).

plunder, n. abin kwache. plunder, tr. v. kuache. plunge, v. 1. tr. (to immerse) tsoma, nutse, nuche.

2. intr. fadi, e.g. he leaped plunging headlong into the water ya tuma ya fadi ya gangara chikin ruwa; see also dive.

plural, n. (grammatical terı) jam'i*.

pneumonia, pleuro-p. of cattle balagiro, malagiro (S.), arangaza (K.).

pocket, n. aljifu, pl. aljifai or aljifuna.

pod, n. (of nuts, etc.) ķobsa, 
kwasfa, ḳopsa, ḳobso, kwanso ; p. of the locust tree (dorowa) sabăda, safada; p. of guineacorn tsirgagiya.

poem, $n$. (in the sense of metrical composition, song) waka. poet, n. mai-waka.

point, n. kokuwa*, tsini, garatse; points above or below letters wăsali.

point, out, tr. v. nuna or nuni, gwada, gaya.

pointed, adj. da tsini.

poison, n. $d \breve{a} f i$; a p. given in food sammu, kwarche; ingredients used in making poisons used for smearing arrows uwal dăfi, zabgai*, yabi, kwankwani (Strophanthus hispidus), taramniya* (Combretum), kokiya (Strychnos spinosa), sanya or uwar magunguna (Securidaca longipedunculata), tururubi (Lasiosyphon krausii), zabon dăfi; a p. used for destroying mice madat, madas.

poison, to gubanta, sammache. poisoned, participial adj. $d a$ dafi.

poke, to p. with a stick zungura, zungau.

poking, e.g. with the elbow gobso, gwabre.

pole, n. gimchiki, gimshiķi, esp. used of the middle sup- porting p. of house; p. of tent tankari, kekimaka (S.); poles used in supporting a tent coll. shikashiki, pl. shikashikai, cf. post; iron p. karko; a $p$. in the middle of a hut shushuniya, shishiniya; a p. used for purposes of irrigation lambu; a p. carried across the shoulder from either end of which a load is suspended taula.

policeman, dan sanda, dogari; the office of a p. dogarchi; the chief of the police makama.

polish, tr. v. gogi or goge, chudanya.

pollute, tr. v. yin haram, kazamta, kazamtad da. polluted, adj. janaba, łazami. pollution, n. 1. gen. kazamta, kazanta, janaba, jaraba, ja'ira.

2. (religious or ceremonial uncleanness) haram, abin ha ram.

polo, the game of wasan lkwălo** pomegranate, n. rǔman, ruma niya, pl. rumanina, rumanai. pommel, n. (of a saddle); see peak.

pommel, tr. v. (to beat) buga: bubbuga, see beat. pomp, n. sitira or sutura. pond, n. a large stagnant.p 
bingi, gaji, kududdufi, kududdifi, dankam, tabki, tafki, tapki, see pool.

ony, n. kūuru and doki kiūru, dukushi, fem. dukusa.

ool, n. tabki, tapki or tafki, rafi, gaji, pl. rafuna or rafuffuka, fadama, ḳorama, dankam, tauga, see pond.

oor, adj. talaka (K.), talakka (S.), pl. talakkawa; makaskachi, pl. makaskasta; to be p. talauta, tsiyache.

oor person, a, n. talaka, maitalaka, matalauchi, mai-tsiya, matsiyachi, gyande, fem. gyandiya, pl. gyandaye, gindau, tagajan.

opping, into a hole kudus. oppy, yellow Mexican p. kwarko.

orch, n. shigifa, pl. shigifu and shigifofi; spec. a small p. shirayi; a p. with double entrance zaure, pl. zauruka, zaurukka.

orcupine, n. beguwa, makaya (lit. thorny), makibiya (lit. possessor of arrows).

orridge, n. füra; spec. p. of guinea-corn and rice surki; p. of beans, guinea-corn or (in N. Africa) macaroni wasawasa.

orter, n., see carrier.

ortion, n. rabo or rabu, pl. raberabe, kashi, kashe; a p. (when one of two or more portions) shashi or sashi*, sashe (S.), fasali, see piece.

possess, tr. v., this idea is expressed: 1. by the pronominal forms ending in $n a$ with $d a$, e.g. I possess much money ina da kurdi dayaua.

2 . by ke with $d a$, e.g. all the property that you p. dukiya duka da ku ke da shi (or ita).

3 . by the prep. ga or with pronouns gare (is to or belongs to), e.g. he possesses no money babu kurdi gare shi.

possessed, e.g. with evil spirit, pl. masu-bori, masu-boli.

possession, n. l. abstr., e.g. to gain p. of a kingdom chin sarauta.

2. concr. pl. possessions dukiya, tarkache.

possessor, n. mai-abu connective mai-abin, mai-chi; the idea is often expressed by the prefix mai-, e.g. the p. of a farm or a boat, maigona, mai-jirigi; the p. of a horse mai-doki.

possible, yuwuwa, yiyuwa. possibly, adv., see perhaps. post, n. (of door) kcwabrin kofa, kwilkin kofa, shishike (S.), shishiniya (S.), shushuniya (K.) ; a p. for tethering 
horses turke, tuke; a p. for supporting roof jīgo, pl. jiguna.

posterior, adj. (both of time and space) baya, na-baya, fem. ta-baya, e.g. the p. limbs gabobin baya or gabobi na-baya; the hinder part of an animal kuturi.

post-haste, zuwan manzo.

postpone, tr. v. fāsa, jinkirta, see delay.

postponement, ko-ta-kwaria. postponing, particip. n. fasawa.

pot, n. (of earth or iron) tukunya, pl. tukane or tukwane; a metal p. karife or karipe; a large earthen $p$. with a narrow mouth randa, $\mathrm{pl}$. randuna, kwatarni (S.), kwatarniya (K.) ; a large earthen p. used as oven tanda or tanderu; a water p. tulu, pl. tuluna.

potash, broken p. tsabage (S.) ; a kind of hard p. takarna, tafarna.

potato, sweet (i.e. Ipomoea batatas), n. dankăli; various species are: $\dot{k} \bar{u} d a k u$, lawur (S.) ; Kaffir p. rizga.

potent, adj. isheshe, fem. ishashiya, pl. isassu; see powerful.

potter, n. mai-tukunya, pl. masu-tukunya, mai-tukane, mai-yumbu*, magini. pouch, n. tumbi, pl. tumbuna; a sort of leathern p. zabira; a p. or crop of a bird maroro, malolo.

poultry, n.kaji,pl. of $k \bar{a} z a$ fowl. pounce, n. sura.

pounce, to kawo sura.

pound, n. (of 12 ounces) rotal, pl. ratalai*.

pound, tr. v. dăka, dandaka, dandaki, daddaka, rarratse, kirba, kirbe (without object), ribde, rifde, rubde; a woman who pounds corn mai-koda, mai-kodiya.

pounded, p. flour ribdi, rubudi. pounding, n. (e.g. of yams) kirbi, rubudi; the action of a woman p. in a mortas lugude; the sound of $p$. rupkarupki.

pour, v. tr. and intr. (also tc pour out, down, off, away: etc.) zŭba, zŭbe, zŭbo; tr. only zŭbas, zŭbas da, zubad da and $z u b d a$, zubshe (Zanf.) dole, tŭshe, bulbula, bungula. tarfa; I poured out every drop of it $n a$ zubas $d a$ shi babu kingi; intr. only zubu e.g. the rain is pouring or pours down ruwa ya zubu to p. water in a jet zurara to p. out (or scatter) tsiyayi 
to p. out grain so that chaff may blow away shika; to p. over (to overflow), intr. tuda or tude, tr. tudas da.

ooured, to be p. out like wheat through a sieve or like water, intr. v. tarara. pouring, zŭbi, zŭbawa. oout the lips at, to, v. (in derision) zunde and yin zunde. poverty, n. talauchi, talauchiya, tsiya.

oowder, n. (gunpowder) albavis or albarud.

oowder, tr. v. (to reduce to p.) daddaga.

power, n. 1. (faculty of doing or causing anything) iko, pl. ikoki, yi; by the power of God da yin Allah.

2. (bodily or material strength) karifi.

3. (political or social p., authority, influence) hakimi, daula.

4. (surpassing p., excellence) fiko.

oowerful, adj. 1. gen. isashe, isheshe, fem. ishashiya, pl. isassu, mai-iko.

2. (cf. prec. 2) mai-karifi, pl. masu-karifi, e.g. a p. man mutum mai-karifi.

3. spec. applied to God kadiri, see mighty, strong. powerfully, adv. da ḳarifi. practice, n. sabo, e.g. no work in the world can be accomplished except by p. aikin duniya duka sai sabo; (customary procedure) $a d a, t a d a$, al'ada.

practised, be, intr. v. $s a b a$, e.g. I am p. in this na saba da wannan.

praise, n. yăbo, kirari, the last also=self-p.; (of praising God) shukra; self-p. yăbon kai.

praise, tr. v. yăba, shukra; yin yăbo and yir kivari; also expressed by nouns of prec. with the present forms in $n a$, e.g. I praise thee ina yabonka. praised, particip. adj. yababbe, fem. yababba, pl. yababbu. prattling, n. rawatsa.

pray, tr. v. (whether of prayers to God or requests to men) roka, yin roko; construed with an acc. of the person or with ga (before pronouns gare); the thing asked is expressed either by the acc., e.g. I p. our Lord for that which I seek and for my needs ubangijinmu ni ke roko komi ni ke bida da bukatata or by a dependent clause, e.g. we p. to the Lord that we may obtain provision for our journey from the heathen mu roki ubangiji 
mu yi guzuri da asna; intr. v. in a religious sense only yin addu'a, yin salla, yin zikiri; to p. for a person sallashe*.

prayer, n. addu'a, salla, salati, zikiri* ; call to p. about 4 p.m. azuhur (S.), azahar (K.); the man who calls to p. ladan, ladāni, makiran salla, wazinu, wazanu (S.); a leader in p. limam, liman, pl. limami; prayers said by a mallam at a funeral alfatiya ; time of p. about 10 a.m. walaha; the four attitudes (Moslem) for prayer are (1) standing up and looking towards Mecca kama, (2) raising the hands and calling upon Allah răka, răka'a, (3) bending down with handson knees ruku'u,(4)prostration sajada. prayer-beads, (a flower) idon zakara.

prays, one who, n. mai-salati. preach, v. yin $w a^{6} a z i^{*}$ and wa'azu.

preaching, n. wa' $\iota z i, w a^{6} a z u$;

p. in mosque after prayers hutsuba (S.), huduba (K.). precious, adj. (costly) da tsada. precipitous, a p. rock mikakken dutsi.

precisely, $r a b$, see exactly. prefer, tr. v. fi so, yin fin so, gwamache, e.g. we p. mutton to beef mun $f i$ so naman rago ya $f i$ naman shanu; I p. this to that $n a f i s 0$ wannan da wanchan.

preferable, to be, intr. v., see better, 1.

preference, fin so. pregnancy, kunīka. pregnant, adj. da chı̌ki; she is

p. ta chi wake; to be p. yin juna bīyu.

preparation, n. shiri, shirya, tătali, tānadi (S.), jajibir, jajibera, in a religious sense, e.g. day of p., i.e. day before any feast ranan jajibir.

prepare, tr. v. gen. gyara, e.g. to p. a way gyara hanya, gyarta; shiriya and yin shiri; used in the intensive form $=\mathrm{p}$. diligently shish shiriya; exclam. phr. p. ! ka watane.

prepared, particip. form shiriyayye, fem. shiriyayya, pl. shiriyayyu.

present, n. kyauta, e.g. I made him a p. na yi masa kyauta, abin gaisuwa, tsaraba*, kai$w a$; the last especially of a p. made to a king; spec. a fee paid for bringing a $\mathrm{p}$. tukwichi, tukuichi; a wife's marriage presents to bridegroom găra; a p. made to a 
person on his arrival sauka; a first p. as a token that a larger one is to follow $g a$ rawa (K.) ; a p. sent by the bridegroom to the bride several days before the wedding lefe; a p. given by a man when he sends for his wife taskira; a p. by a bridegroom toshi.

presently, adv. (soon after the present time) yanzu yanzu; (immediately) nan da nan.

preserve, tr. v. kiyaye, kiyada (S.), kiyas da (K.), kiyashe; in a looser sense tsira, rayad da.

president of the market, $n$. sarikin kasuwa.

press, tr. v. taushe (S.), tausa (K.), mana, mani, matse, matsa, dăna, dăne, danfara, dankara; to p. down tawaya or tauwi, chăchăka, chusa, chushe,kimshe; to p. a trigger dane; the trigger was pressed an dana kunama.

pressed, particip. adj. tausashe, fem. tausashiya, pl. tausassu.

presser, n. instr. mataushi found, e.g. in mataushin kofa a piece of wood to keep a door closed, mataushin watika signet.

pressing, particip. n. taushewa. pretence, riya, sāne. pretend, v. maida kansa, riya. prettiness, sha'awa (K.), shawa (S.).

pretty, he is p. shina da magāna.

prevail over, v. rinjayi or rinjaya; also expressed by means of $f i$, e.g. I prevailed over the man na rinjaya mutum or na fi mutum da karifi or mutum na fi karifinsa.

prevent, tr. v. hana, tankwasa, dakile, tare* ; to p. a person's leaving hume, e.g. I prevented his leaving na hume shi.

previous, adj. na-fari, fem. ta-fari; (of time long p.) na $d \bar{a}$, e.g. p. time or age lokachin $d \bar{a} ;$ men of $p$. ages mutane na dā or mutanen dā. previously, adv. da fari, e.g. why did you not tell me this p. ? clomi ba ka fadi ma ni nan da fari?

prey, n. 1., see booty.

2. (food of an animal of p.) nama, e.g. the lion catches deer, that is his p. zaki ya kama bareyi ya chi su namansa ke nan.

price, n. kurdi, an taya, kìma, tamani*, săllama, haki*, e.g. what is its p.? kurdinsa naca? or nawa an taya? name 
its p. ba shi suna; to fix a p. for kawamata, e.g. let their goods be gathered together and their p. fixed a gangama dukiyansu a kawamata; a reduction in p.gwanjo; to fall in p. yin goino (or gwano). prick, tr. v. soka, soke or soki, tsokana; to p. much (intens.) sossoke.

prickle, n. (on grass, etc.) kaya, pl. kayayuwa.

pride, n. foma, homa, tama, tamanya, girman kai, büki, tashin kai, gatsina (K.), fadin zuchiya, fadin rai, güri, fahari or fahri, e.g. leave off p. ku bar fahari.

pride of India, (flower) kurnan nasara.

priest, liman*.

prince, n. amiru*; (son of a king) maina*, dan sariki; princes sarakuna.

prison, n. kurkuku, kililu, kilulu, sadaka, salka, sarḳa, dākin dufu, wurin azāba, gidan kwaliba*; chief of a p. bakurme (K.), bango (K.); p. officer bayare (S.), yari, pl. yarawa.

prisoner, kamamme, dan sadaka.

privet, Egyptian p. lalle. probe, to kŭre.

procession, n. jera, jere or jire ; spec. a royal p. banga banga.

proclaim, v. 1 . to make an official announcement or order yin shela, yin yekuwa.

2. to announce or publish labarta, habarta*.

3. spec. to p. the end of the fast yin gangamin azumi. proclamation, n. 1. (an official public announcement or order) shela, doka, doki, kaliye, yekuwa.

2. (deliverance of religious or moral instruction) wa'azi, wa'azu.

procrastinate, v., see delay. procure, tr. v. same, samo and samu.

procuress, kawaliya, kalwaliya (S.).

prodigy, karāma, see wonder. produce, n. diya, yaya. produce, tr. v., to p. young or fruit haife; to p. evidence kai (or kawo) shaida.

profanely, to act, v., e.g. he acted p. ya yi swabon Allah. profession, n. (of an art or craft) gwari ; the termination $-c h i$ is often used to denote a person's p., e.g. the p. of a bok $a=b o k a n c h i$, the p. of a malam = malamchi. profit, n. (both lawful and unlawful) kūra, rība, moriya; 
unlawful p. haramiya; to make a p. chin rïba, mori; a man who sells a second time at a p. mai-sari; men who make unlawful p. masu-riba da küra; to p. by anfāni, anfāne.

profitable, to be, v. yin moriya. profligacy, karma, karuwanchi. profligate, n., a p. ashĕge, farka; a p. man fasiki, pl. fäsikai, dan karma, mai-yin zina, mai-zina, mai-nema; a p. woman fäsika, karuwa. profligate, adj. shege; to be

p. yin zina.

prohibit, to hăna.

prohibited, a p. place bataka, hurumi*; it was p. an yi hani.

prohibition is expressed by kada, also by kada dai, e.g. do not hinder them kada ka hana su or kak ka hana su. orohibition, n. hani, doka*, kashedi, kasheji (S.).

oroject, to yota; (e.g. of a single man in a row) saba, zaba, billo, bulo, bullo.

rolong, tr. and intr. v. dadi, dade, tsawo, wanzu, e.g. may God p. your life Allah shi clade da ranka; impers. we prolonged our stay here mun zamna nan ya dade; the last idea can be expr. by dade alone in personal constr., e.g. I prolonged my stay in Tripoli to four months na dade ga T'arabulus wata fudu.

promenade, intr. v. yawo, yin yawo.

promise, n. alkăwali, alkăwari, $w a^{6} a d i$; to make a p. yin alkăwali; to break a p. sāki and warwari alkăwali; to keep a p. chika alkăwali, chika magana, kama magana; a p. to pay waka.

promise, v. yin baki daya, yin magana daya.

prone, (on the back) a rigingini.

pronounce, "v. (to declare openly or positively), see declare.

pronunciation, n. halshe, harshe, pl. halshina or halussa. proof, n. shciida; to adduce p. kai or kawo shaida; p. (e.g. from the Koran) in support of conduct or statement dalili. prop, n. mădōgara, makari, tankari; see bar.

prop, to, v. dogare, tankare. propagate, tr. v. (to have young) haife, haife diya. propel, tr. r., e.g. a canoe tun. kuda.

proper, adj. na-kivarai, fem. ta-liverai, halal, halas, sosai, 
daidai; that which is $p$. sawaba.

properly, adv. kwarai, daidai, tamau, sosai, bajau.

property, n. (goods, riches) dukiya, pl. dukoki and dukiyoyi, jăli, mallaka, tarkache ; a man of p. mai-dukiya, mai-abin dukiya, mutum da dukiya dayawa, mai-wadachi and mai-wadata.

prophecy, n. annabanchi, an- nabchi, waliyanchi.

prophesy, v. yin annabanchi. prophet, n. annabi, pl. annabawa; the office of a $\mathrm{p}$. annabanchi.

proprietor, n. gen. (owner) mai-abu, conn. mai-abin, maichi; (house owner) ubangiji; see under mai.

propriety, n. halalchi*.

prosper, v. 1. tr. ba (or bada) arziki, e.g. may God p. you Allah shi ba ku arziki.

2. intr., see prosperous. prosperity, n. arziki, abki, afki, auki, katari, katarta*, yalwata, bijinta, alkariya, gata, gatanchi; he has enjoyed p. ya sha ruwa; he has enjoyed p. in this world ya sha duniya.

prosperous, adj. da arziki, mai-arziki, mai-katarta; he is p. ya yi bijinta; he shall not be p. ba a yi masa arziki ba.

prostitute, n. karuwa, kwartuwa (fem. of kwarto), falka, farka, mai-nema.

prostrate oneself, to, v. yin afi, kafa goshi, gurfana and yin gurfani; (of prostration in worship) yin sujada, also with na, e.g. follow after God, p. yourselves before Him ku bi Allah kuna sujada.

prostrate, to be, v. rubda (or rufda) chiki, yin ăfi.

prostration, n. (i.e. in prayer) raka.

protect, tr. v. tsăra, tsări, tsăre, tsăro, batāka.

protection, n. lamuni*, kāriya*; he has the king's p. ya shiga rigar sariki.

protector, n. (defender) maitaimako.

protopterus, n. (mud-fish) gai$w a$; the noise made by the p. chiwuki. protrude, to zazzale.

protruding, e.g. of an eye after a blow zazzalo.

proud, adj. mai-girman kai, pl. masu-girman kai, da girman kai, mai-girima, mai-foma, mai-homa.

proudly, adv. da girman kai;

to speak p. yin raha; to 
walk p. takama; one who walks p. mai-takama.

prove, tr. v. (to establish the truth of anything) gaskata or gaskanta ; (to evidence by testimony of any kind) kai (or kawo) shaida; (by exposition or argument) gaya, nuna or nuni.

proved, particip. (attested, certified) shaidadde, fem. shaidadda, pl. shaidaddu. proverb, karin magana, sara. provided that, this conj. is expressed by adding emphatic particles dai, fa to in, idan, e.g. in dai, idan fa.

provision, n. provisions for a journey guzuri; to make or obtain p. yin guzuri; fig. of p. for the next world, e.g. repent, seek $p$. for the way that thou mayest prepare to make a journey $k a$ tuba $k a$ nemi guzuri don ka shiriya yinin tafiya.

provoke, tr. v. harzuka ga, hasăla ga, haye*; I was provoked at this saying $n a$ ji fushi da maganan nan.

prowl, to p. round $z \bar{a} g a, z a z z a g a$. proximity, see nearness.

proximo, adv. (e.g. next month) watan gobe.

prudence, n. hankali, fahimi, basira. prudent, adj. mai-hankali, pl. masu-hankali; to be p. shr̆ga hankali, hankalta.

prudently, adv. da hankali.

Psalms, n. zabura*.

puberty, one who has reached,

n. balagagge, pl. balagaggu; children approaching the age of p. banawa; a boy approaching p. matashin balaga; a girl approaching p. matashiyar balaga; the age of $\mathrm{p}$. lokachin balaga.

puberty, to reach, intr. v. $b a$ laga.

publish, tr. v. (i.e. to p. a thing or news of a thing) labarta, habarta*.

pudenda, n. al'aura*, matıchi fem.

puerility, n. halin yaro.

puff-adder, kasa.

puggaree, a red. p. jan tunka. pull, tr. v. ja, jaka; to p. out chira, chire, fitas da, fusge, fizge or fisge, tabe, tabi, sakatta, sakache, tuge, zara, zare, zari, zaro, e.g. he pulled a pistol out of his pocket $y a$ fitas da akotiya daga aljifunsa; to p. out (as a hair, grains from a stalk) tsefe, (as roots) tona or tone, tumbuke; p. out the grass a tumbuke chiyawa; to p. towards oneself jawo; to p. in towards 
oneself miko; to p. up a horse zami, zame; p. up here! zami nana.

pulley, on a Hausa loom on which the peddles work chikalkora; see under weaving.

pulse, daldal. pumping beam, n. kutara*. pumpkin, n., names of different species are: large garden p. (Cucurbitapepo) kābewa(K.), kubewa (S.), goji (Z.); a smaller p., used in making soup miya; a white p. not eaten, used for making waterpots dŭma, masc. pl. dumaimai or dumaye.

punch, to fidda naushi. punctuation, signs of fări. punish, tr. v. fallasa, pallasa or pallashe, foro, yin wahala, yin foro.

punishment, n. fallasa or pallasa, azāba, foro; a legal p. ukuba (S.).

pup, n. kwikuyo, kwikwiyo, kuyikuyu, pl. kuyikuyai, followed by kare.

pupil, n. 1. (a school-boy) dan makaranta, pl. yan makaranta, yaron (pl. yaran) makaranta; (of adults and spec. those of a religious teacher, i.e. disciples) almajiri, fem. almajira, pl. almajirai.
2. p. of the eye ijiya, ijiyar ido, matsokachin ido.

puppy, n., see pup.

purchase, tr. v., see buy.

pure, adj. 1. (in a material sense) tsari, tsalka or tsatsalka, da tsalki, tsatsarka, e.g. p. wheat, i.e. clean, in good condition alkama tsari, (of metals = unalloyed) safi or safe, e.g. p. silver azurfa safi=azurfa babu ha'inchi; (=simply) tsāba and tsala, kŭna, e.g. p. and simple cowries, i.e. nothing but cowries tsāban kurdị; nothing but water ǩŭna ruwa.

2. (in a ceremonial or moral sense) tsari, chari, da tsarki, da tsabta, halal, halas; p. water ruwa da karari; to be p. yin tsabta, tsalkaka, tsarkaka.

purgative medicine, n. $m a^{-}$ ganin zawo, maganin gudundaji;purging nutbinidazugu. purge, to kawashe.

purification, n. esp. ceremonial

p. tsalka or tsatsalka, lullo; p. of a woman after the birth of a child $b \bar{i} k i$.

purify, tr. v. tsarkake, charkake.

purity, n. tsarki, tsalki (S.), tsabta, tsapta, tsauta, halalchi, karari. 
purloin, tr. v., see steal.

purple, shuni.

purpose, n. ganganchi, hamzari, hanzari.

purpose, on, adv. da gangan ; to no p. banna.

purring, e.g. of cat or hyena gurnani.

purslane, fasa kaba; horse p. gadon machiji.

pursue, tr. v. (as in war) farfaro or faffaro; he pursued his way ya kama hanya.

push, tr. v. tūka, iza, ije, surmuka, tura, turi, ture, zungura, damfare, the last of pushing so as to cause one to stumble; to p. towards oneself ture; to p. aside tunkuda, bankada, bankade, kide; to p. into water gangante; pushing with the knee güla.

pushing, turo.

pustule, n. (boil) kurji, pl. kuraje, kureje, kuraraji.

put, tr. v. sa, sanya, aje; to put one thing on another $\breve{a} z a$ or $a z a m a$; to p. aside (to cease from) $s a$, e.g. let us p. aside quarrelling mu sa ḳankanchi (to lay up) aje; to p. away kauda, kawas; to p. on (of clothes, etc.) $s a$; to $\mathrm{p}$. together tara; to p. down a load jī de. puzzle, n. zauranche, see riddle.

puzzle, tr. v., see perplex.

pyramid, see cone.

python, n. mesa, mulwa*.

quack, n. (a pretender to medical science) boka, pl. bokaye.

quackery, n. bokanchi; cf. prec.

quake, intr. v., see tremble.

qualm, n. 1. (a feeling of nausea) kumiallo.

2. (a conscientious scruple or hesitation) kumya.

quantity, n. (an amount of anything) mashasha, afki, sununu, tsibi; a large q. gugu, gugi, e.g. a large q. of sand gugin rairai, jibgi, the last esp. of food ; taro, taru, yawa, yawanchi, also dayawa, e.g. his discourse was nothing but a great q. of words w'azinsa saiyawan magana; see much; a small q. $k a-$ ranchi.

quarrel, n. fusīma, jaya, jayаyуа, husūma, tsalmi, see seq.

quarrel, intr. v. yin jaya, kankani, yin kankanchi; to $q$. with yin kankanchi da, in the sense of to maintain opposite opinions gardama 
with the forms in $n a$ or with $y i$; fada (lit. to fight) is also used.

quarrelling, kankanchi, säba. quarrelsome, adj. futsu, hutsu, mafadachi, mai-ijiat yaki; he is q. ya tarika fada.

quarter, n. 1. (a fourth part) rubu'i*.

2. (a division in a town) shiya, pl. shiyoyi, unguwa, pl. unguwai and (in Sokoto) ungunni; cf. seq.

quarters, n. (place of stay, lodging) masabki, mazamni, also loosely wuri.

quash, tr. v. (to make void) wofinta.

queen, n. 1. (a female sovereign) sarkanya.

2. (a king's wife) sarauniya, matan sariki.

quench, tr. v. (to put out a light or fire) kufuli*; pass. to be quenched (to go out) mutu, e.g. the fire is quenched wuta ta mutu.

query, n., cf. seq.

question, n. tambaya, binchike, mas'ala*.

question, v. tambaya, yin tambaya, yin binchike, tantambaya.

questioning, n. (discussion about something doubtful) kokanto, binchı̌ke, binchı̌ki. quick, adj. 1. (rapid, im. mediate) sauki, da sauri; a q. death (or a sudden death) saukin mutuwa.

2. (alive) da rai.

quickly, adv. (at once, with the least delay) $d a$ sauki, da sauri, nan da nan; (at a rapid rate) măza, ribta, rupta, garr, kìdis, kŭdis, samli, rugu*; very q. maza maza contr. malmăza, e.g. he is counting the cowries very $q$. yana kilgan alkawara măza $m \check{a} z a$; to go q. (lit. to blow a hole through the ground) füra kasa.

quicksilver, n. zaiba.

quiet, adj. (implying cessation from speech or cries) $d a$ kawai, jurum; to be q. yin shiru (or shuru), yin kawai, kawaita, rüma (S.), yin kurum; (of disposition) lalafa; cf. seq. ; keep q. kame bakinka. quietness, n. kăwai ; (of disposition) lalafanchi. quit, v. (to leave or abandon) bari or bar, e.g. q. this custom ku bari tadan nan; of a path sau.

quite, adv. 1. (wholly, nothing but) sai which is either applied to the entire clause, e.g. if he refuses this you may call him quite a coward 
in ya ki nan sai ka kirawo shi matsorata, lit. you may quite call him a coward, or, as in Engl., applied to a particular term, e.g. his face was q. bloody fuskassa saijini; he is not q. dead ba ya ida mutuwa; so in the very common expression sai lafiya quite well.

2. (less precisely = very much, indeed, truly) dayawa, lcwarai, e.g. we are q. pleased muna jin dadi dayawa; I was q. frightened na ji tsoro dayawa; I q. understand $n a j i$ sărai; adv. phr. quite so ashe, da gaskiya, ya yi haka.

luiver, n. kwari, kwarin kibiya, gidan kibiya.

luiver, intr. v., see shake, tremble.

abble, n. (low class of men, the mob) taro banza.

abid, adj. mahaukachi, e.g. a r. dog mahaukachin kare ; see mad.

ace, n. 1. (ancestral stock) ǔsali, asali.

2. (a particular breed of men or animals) iri, pl. irare.

3. (a running in contest of men or horses) tsēre, tseray$y a$.

addish, a kind of fijir. radiant, adj. (emitting light) mai-haske, pl. masu-haske.

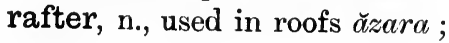
see reed.

rag, n. (in the sense of a small piece of any stuff) $d a$, e.g. a cloth r. dan zane, dan barki, dan yanki; see rags.

rage, n. fushi.

rage, intr. v. haukache, yin fushi, jin fushi; see angry. rags, n. coll. ragga, pl. răgguna, tš̌mma, pl. tsummokarai, tsummoki, kēso*, chuna*; singulars of both are used as collectives, old r. chukuchuku; trop. (in the sense of old or tattered clothes) răga, ragga, pl. raggogi (S.), tsum$m a$; clothed in r., adj. funtu or da funtu.

raid, n. sati, esp. a surprise slave r. by horsemen hări; raiding of a town $b \bar{a} s \bar{a} s a$.

raider, (i.e. slave-raider) $m a$ hări, pl. mahara.

rain, n. ruwa, pl. ruwaye, ruwan b̆sa, ruwan sama; spec. gentle r. yayyafa, yinyifi; a cloud which threatens, or produces rain zirnaniya; heavy or lasting r. malka (S.), marka (K.), mako, mamako, pashi, taguwa; light r. tsatsafa; the night has been passed in the r. an 
kwan da ruwa; the r. pours down ruwa ya zuba; in the r. da ruwa; a r. cloud jitau.

rain, v. 1. impers., it rains ana ruwa and yana ruwa; it rained an yi ruwa; to $\mathrm{r}$. heavily or long yin taguwa, yin malka, sarafa* ; the r. stopped aka dauke ruwa; it is raining slightly ana yayyafa.

2. used in a fig. sense to cast or shower down like r. turn by means of a comparison common in Hausa kaman ruwa, e.g. our guns r. bullets on the enemy bindigoginmu sun jefa da harsashe a bisa abokan-gaba kaman ruwa; he speaks fluently ya yi magana kaman ruwa, lit. he speaks like $r$.

rainbow, n. masha-ruwa, mashan-ruwa, bakan ǧzo, bakan Allah; the spirit of the r. gajimare.

rain-drop, n. $\operatorname{tar} f *$.

rainy, adj., see rain; r. season damăna or damuna, cf. rani; a break during the $r$. season fari.

raise, tr. v. (to make or cause to rise, also to set up) tada, tayas, tayas da, tashe, tāsăd da, hankada, hau da, haushi, hausa; (to lift or pick u anything) dauka contr. da do.

raisin, zabibi*.

rake, n., with two prone mashari.

rake, tr. v., spec. to $r$. togethe cinders or embers of a fir aza (or hasa) wuta; I r. $\mathrm{u}$. cowries towards me na ton kurdi.

ram, n. rago, pl. raguna, bun suru, pl. bunsurai or bun suraye; spec. a large Bor nuese r. ără̆ra; a red anc white r. kargo ; a long-earec r. $u d a$.

Ramadan, n. (the moham medan fast month) watar azumi.

ramble, intr. v. (to wander about) yin yawo.

rambling, n. yauwa.

rampart, n. ganuwa.

ramrod, n. tsatsagawa, maruashi.

rancid, to be or become, intr. v. ruba.

range, n. (of hills) kuduniya. range, tr. v. (to dispose in regular order) daidaita. rank, (i.e. line) jeri, pl. jerori, to form r. jera.

ransom, n. pansa, fansa, hansa; or r. paid for a captured slave gumki, kurdin turu; 
money paid to set a slave free kurdin kariya turu.

ansom, tr. v. panshe, panshi, fanshe, e.g. pass. let him be ransomed a fanshe shi.

ansomer, n. ag. mai-fansa.

ansoming, n. pansawa, fansawa.

apid, adj., see quick.

asp, n., see file.

asp, tr. v. gogi or goge.

at, n. dambariya, bera or bira (K.), kusu (S.); large palm r. (cane r. or ground r.) gyabji, gyauji, or kusun kyamro; large Gambian r. burgu, fem. gafiya ; the stinking r. or shrew jāba.

attle, a chăki; a pod used by children as a r. baranchaki, kachokacho.

attle, to yin chăki.

ive, intr. v. haukache and hauka, see raving.

ivening, n. zowari, zwari.

ivenous, to be kwaraka.

ivine, n. kanga; a r. with water in it kogi, pl. kogunce or kogai, korāma; a waterless r. kwazazzabo, kwări.

ıving, adj. mai-hauka, maihaukachi; to become r. yin raurcuwa; see mad.

w, adj. lanye, danyi, pl. danyoyi.

R. H. D. ray, of sun giraza, girazal rana.

raze, to, a town, baji, baje.

razor, n. aska, pl. asake or askake.

reach, v. 1. tr. (to extend, or hold out) mika, e.g. I reached my hand to him na mika masa hannu.

2. intr. (to arrive at) isa, ishe, iske, kai, e.g. the boys swam and reached the land yara sun yi iyo sun kai kasa.

3. (to overtake) taras.

4. trop. (to be sufficient as in Engl. "the money will $\mathbf{r}$. so far') iya, isa, ishe, kai, e.g. it wont r. (it is insufficient) $b a s h i k a i$.

read, tr. v. karātu, yin karātu, karanta; to r. through shide; to $r$. a second time tŭsa $k a$ ranta.

readiness, n. shiriya.

reading, n. karatu, bita.

ready, participial adj. (prepared or in readiness) shiriyayye, fem. shiriyayya, pl. shiriyayyu; r. money hannu da hannu ; cf. seq.

ready, to make, v. l. (in a general sense but also very commonly of preparation for an expedition, journey etc.) yin shiri, shiriya, e.g. a 
prudent man would prepare for to-morrow's journey today don tafiyar gobe mutum mai-hankali shi kan yi shirin yau; we have a journey before us which cannot be put aside, whether you are prepared or unprepared muna da tafiya ba fasawa in ka yi shiri da izan ba a shiriya ba; so also gyara, e.g. to make r. a way or a load gyara hanya or kaya; to make r. (by mending or by putting to rights and in order generally) gyarta.

real, adj. na gaskiya, da gaskiya, also gaskiya and gaske added to the term to be thus qualified; of persons maigaskiya, e.g. he is a r. friend shi ne aboki mai-gaskiya, which may also be expressed by shi ne aboki da gaskiya, lit. he is a friend in reality. reality, n. sakankanchewa, gaskiya, e.g. whether this be r. or falsehood I know not ko gaskiya ko ḳariya ban sani $b a$; cf. seq.

reality, to assure of the $r$. of, tr. v. gaskanta.

really, adv.da gaskiya, gaskiya, gaske, jidda*, e.g. it is r. so da gaskiya hakanan shi ke or simply gaskiya ne; (used as interrogatives or expression: of surprise) ashe, ai, ainin. anya, e.g. r.? or r.! ashe. realm, n. sarauta, mulki*, zati. reanimate, tr. $v$, (to recall to life) raya.

reap, tr. v. girba, girbi, yarika, yanke, yin sāra.

reaped, e.g. r. corn sankache, jene.

reaper, n. mai-girbi.

reason, 1. (cause) sabăbi, ǩ̌bu (S.), sabili, sanadi.

2. (a r. given as an excuse) huja or fuja.

3. (authority from Koran etc. or origin of a myth, story etc.) dalilli.

4. (the intelligent faculty) see ability; adverbial phrases, for this r. domin haka, don haka, for that r. domin or don wannan, domin chewa*; this is the $\mathrm{r}$. ita che dalili or shi ya sa; it was past r. ya wuche missali; what is the r.? ina sabili? reasonable, to be shiga hankali; be r. shı̆ga hankalinka. reasonable, mai-dalili. reasoning, n. kokanto; to engage in r. yin kokanto. rebel, n. makangari. rebel, intr. v. yin kangara. rebellion, tawaye. rebellious, pl. tawaye. 
bound, n., e.g. of an arrow tura.

bound, intr. v. tankwashe, lankwashe, e.g. the spears rebounded from the coats of mail masussuka sun tanlawashe daga lifida.

buke, tr. v. tsaushi, tsawata $d a$, yin tsawa, e.g. the learned man rebuked his disciples malami ya yi tsawa ma almajiransa; he rebuked me ya yi ma ni tsawa.

ceipt, amsa.

ceive, tr. v. 1. (to take what is offered) karba, karbi, daula, doka, samu, imperat. receive karbo.

2. (of a salutation) karba, o.g. they received, i.e. acknowedged your salutation sun 'arba gaisuwakka; (of news tc.) $j i$, e.g. we received news nun $j i$ labari; to r. as a ;uest shide, e.g. they received ne joyfully suka shide ni da uurna.

eived, particip. (approved f, agreed to, believed in) ardadde, fem. yardadda, pl. ardaddu.

eptacle, n., any kind of $r$. ay be expressed by gida, 1. gidaje or gidadaji; by leans of this are formed he Hausa equivalents of various Engl. terms, e.g. a needle-case (lit. r. of needles) gidan allur $\alpha$; a quiver gidan kibiya; an envelope gidan takarda.

reception, a royal, n. turake. recess, n. (nook, closet, small room etc.) loloki, pl. lokokai, lungu; secret recesses coll. lolokin asiri.

reciprocal, adj., turn by the recipr. pron. juna.

reckless courage, with, adj. jan namiji.

reckon, v. kida, kilga, kirga, see count, number; to $r$. up (take account of) $z \bar{a} n a$. reckoning, n. 1. (computing, calculating) kidaya, kida and kididdiga, hisabi (S.) ; (of accounts) lisafi or lasafi.

recline, intr. v. dangana, kishingida or kishinkida (this also $=$ to sit with crossed legs), jingina, jingine.

recognise, to gani*, gane*. recollect, tr. v. (to remember)

tuna, tuna da.

recollection, participial $n$.

tunarva.

recompense, n. (both of pecuniary reward, wages, and also generally) lada.

recompense, tr. v., see repay, requite and reward. reconcile, tr. v. gama dadi*. 
reconciliation, sulhu, sulfa*, sulba*.

record, n. ambăto.

recover, v. 1. tr. (to get back), e.g.he recovered his property ya samu dukiyassa kuma.

2. intr. (of health) samu afuwa, yin rangwame, mike; he recovered his health ya samu lafiya; to $\mathbf{r}$. from a swoon yin hankali; he is not quite recovered $b a$ ya ida warkewa ba; I recovered na samu sauki.

recovery, n. (of health) rangwame, afuwa.

red, adj.ja, pl.jajaye ; staining r. jaje; very r. ja wur; a r. dye garura.

reddish, adj. jaja karlan, jache. redeem, tr. v. fanshe, panshe, yin fansa, e.g. we redeemed him from slavery muka fanshe shi daga bauta.

redemption, n. fansa, pansa, fansawa ; diyauchi (lit. freedom) also bears the pregnant sense of $r$.

reduce, tr. v. 1. (generally, to lessen, to decrease) ragi or rage; to be reduced ragu.

2 . to r. amount of an account or charge yin rangwame, rangwamta.

3. (to conquer, subdue) chi. reduction, n. 1. (lessening assuaging of anything) $r a$ guwa.

2. (of an account) ran gwame, e.g. make me a r ka yi ma ni rangwame. reed, n. gōra, pl. gorori, kăre pl. kărāre, kara,jiniya; spec of various qualities and user a kind of $r$. or rough grass Spanish r. gabara; a r.grow ing amongst and resemblin guinea-corn kusumburwa ; a edible water r. bindu, bindc a r. used for making arrow kyamro (S.), kyauro (K.), $\mathrm{f}$ kyaniare, gazara*, sheme reeds such as are used fi making doors etc. asabar tsabre; reeds forming circ lar bindings near the kwane inside a roof murdaka, mi daka, magwadi (S.) ; a pla where reeds meet in $t$ centre inside thatched ro kwando; reeds bound 1 gether forming inside bin ing of a thatched roof tank a r.-like plant of which nati ropes are made rama; a used as a pen alkălami; also garanya (K.).

reed-buck, kaji.

reeling, n. (staggering) $n$ gagi.

reference, with r. to bătun. 
ceflection, n. (consideration, thought) tunanne, pl. tunannu.

refrain from, tr. v. bari, bar, e.g. r. f. falsehood $k a$ bar kariya; r. f. laughter rike dariya.

refuge, n. matsira, macheto. refusal, n. kiwuya, kiyuya, hănawa, tayazwa; r. to hear kin $\ddot{j i}$; r. to work kivuuya, indainda.

refuse, n. kazamta; r. food kamzo, kanzo.

refuse, v. ki, kiya, kinkinta, rena, yin kishi, dakile, tayaz; to $r$. an offer in buying and selling hăna and saidaba*; to $r$. exertion (or labour) yin kiwuya; to r. to keep a promise yin gase; to r. to listen kyale.

refuses, one who r. to work, n. makiyachi, mai-kiwuya.

refusing, n. participial form hanawa, kiyawa, kiyaya.

regard, n. 1. (attention, heed) hankali.

2. (affection) soyayya or soyaiya, kauna, kamna, e.g. an object of r. abin kamna; you have forfeited my r. $k a$ yanke ma ni kauna.

regard, tr. v. 1. (to look at attentively both physically and mentally) duba.
2. (to heed) yin hankali, kula, construed with $d a$ before the object regarded. regent, n. makadashi, makaddashi, makadas.

region, n. waje, pl. wajeje. regret, v. (to repent) tuba. reign, n. 1. (royal authority, power) sarauta.

2. (the time a r. lasts) zamani.

reign, intr. mallaka; see rule. rein, v., to r. in zami, zame. reining-in, n. zamiya.

reject, tr. v. ḳi, ḳiya, yada*, e.g. they rejected the right way sun yada hanya; to $\mathbf{r}$. as something bad yin tsantsani.

rejoice, v. 1. intr. yin or jin farin chiki, yin or jin murna; to $\mathrm{r}$. with anyone yin bishara.

2. tr. bada (or sa) murna. rejoin, intr. (to answer) yin amsa.

rejoinder, n. (answer) amsa. relate, v. fadi, fada.

related, to be danginta.

relation, n. dangi or dăgi*, pl. dangogi, kwatana*; cf. seq.

relations, coll. dangi both in the sing. and pl., kibanta, makusato.

relationship, ‥ zumunta*, juna. 
relax, v. 1. tr. (of bonds etc. to loosen) kwanche, kunche, săke; (of efforts, rule etc. to make less severe or strict) ragi, rage.

2. intr. (to become less strict or severe, of anything, e.g. pain) ragu.

relaxation, n. 1. (in sense of

2. prec.) raguwa.

2. (rest) natsu, natsuwa.

release, tr. v. saki and in a looser sense bari, bar; see let.

reliable, adj. (vulg.), see trustworthy.

relieve, tr. v. (e.g. one of a load) tariyo* ; (to assist) see help.

religion, n. addini; the true $r$. addinin gaskiya ; the mohammedan r. musulumchi; he was converted to the mohammedan r. ya zama musulmi.

religious person, n. maiaddini, pl. masu-addini.

rely on, v. dangana, ingata, constr. with da or ga, yarda with $d a$; to $r$. on God $k a$ sada; to r. upon a person shaduda or saduda.

remain, intr. v. 1. (of staying or stopping in a place) zamna, zauna, kasanchi*, kwana (lit. sleep), e.g. we remained there two days mun kwana nan kwana biyu; we remain for this one day only mu ke yini ranan nan.

2. (of remaining in one state as well as place) duma, dawama, kasanchi, tabbatawa; (to be over) yin răguwa. remainder, n. saura, shaura, shawara, duddr̆ga, kanfa (S.), kingi, răguwa, răgowa (S.), shingi (K.), ringi; r. of food marmashi, sudi, suddi; r. of nuts, food, etc. kāla.

remaining, 1. participial adj. (also r. over) mai-wanzuwa.

2. (continuing) mai-dawama.

3. n. (continuance, staying) dawăma, tăbbata.

remains, see remainder.

remedy, n. (in medicinal and also in general sense) $m a-$ gani, e.g. the filasko plant is a r. for diarrhoea filasko maganin gudawa; prov. if a town be far off the $r$. is travel maganin gari da nesa tafiya.

remember, v. tuna; to come to r. tuna with $d a$ before object.

remembrance, n. (recollection) tunanne, tunawa, tuntuna.

remind, to taso*, tuna ma. 
cemiss, adj. lalafa.

cemission, $\mathrm{n}$. (forgiveness) gafara, yafeuva*.

emissly, adv. da lalafanchi.

cemissness, n. lalafanchi. remit, tr. v. (to forgive) yarda, gafarta, yin gafara; to r. a debt yarda bashi; to r. a law tsaida.

remnant, e.g. after cloth has been measured, n. gutsura, see remainder.

remorse, n. nadāma (S.), nidāma, ladāma, da-na-sani; where there is no wrong, there is no r. babu laifi, babu tunanne.

remote, adj. 1. (distant in place) na nesa; also da nesa and daga nesa, e.g. a r. town gari da nesa.

2. (distant in time) $n a d \vec{a}$, also da wuri or dauri, e.g. $\mathrm{r}$. customs tadodi na $d \bar{\alpha}$.

\section{cemoval, ḱaura.}

cemove, tr. v. kauda, kaushe, kauwa, kawas, kawas da.

rend, tr. v. keche, kiche, keta, murtsuka, tsāga; to r. in pieces fatattake, tsatsaga.

cender, tr. v. 1. (to give) $b a$ or bada.

2. (of an account, to give, give in, present) to $r$. an account yin lisafi.
3. (to translate) juya, sauya, fasara, yin fasara.

4. (to cause to be or become) periphr. e.g. the heat of the fire rendered his face very red zafin wuta ya sa fuskassa ta zama ja wur.

rending, n. fatattăka, tsāga, see tearing.

renew, to sabunta; renewing sabunchi (K.), sabuntaka. (S.).

rent, n. ijāra, sŭfuri.

rent, tr. v. (of houses, etc.) süfurche, sufurchi, sufurta, yin sŭfuri.

repair, tr. v. (to mend) gyarta, gyara, lallaba*, yin adana.

repairing, adana.

repast, n. 1. (a meal) kalachi.

2. (food, victuals) rbinchi, chima, chimaka.

repay, to yika.

repeal, tr. v. kauda, e.g. the king repealed the prohibition sariki ya kauda doka.

repeat, v. 1. (to do again), see again; to r. an action yin maimai, maimaita, k̦āra, ribbi*.

2. (to say a thing over again) tusa.

repel, tr. v. kora, kore; to be repelled (of an arrow, etc.) tankwashe. 
repent, intr. v. tuba, e.g. repent! ku tuba; if he refuses to r. idan ya ki tuba.

repentance, n. tuba, nidama,

nadāma (S.), ladāma.

repents, one who, n. mai-tuba. repetition, (i.e. doing any-

thing over again) takidi*.

reply, n. amsa, amshe; to give a

r. ba (or bada) amsa; cf. seq. reply, intr. v. amsa, yin amsa, e.g. he replied to them ya amsa ma su or ya yi ma su amsa.

report, n. 1. (rumour, news) labāri, e.g. we heard a r. about war muka ji labarin yaki.

2. (fame, repute) yăbo.

3. (noise of gun) $\breve{m} m *$, kārar bindiga.

4. false r. tsëgumi, pl. tsegunguma.

report, v. (to bring news) yin labāri, ba (or bada or fadi) labäri; to r. against (to inform against) sare, sara. repose, n. 1. (lying at rest) kwantawa.

2. (rest, quietness) futa, futawa.

3. (sleep) barchi, kwana.

repose, v. 1. tr., to r. confidence in $s a$ with bisa or bisa $g a$ and substantives given under confidence, q.v.
2. intr. (to lie, to be placed) pass. of aje and $s a$; (to lie at rest) kwana. reprehend, tr. v. (to reprove, censure), see blame. reprehensible, adj. da laifi representative, n. (an agent or substitute) wakili. repress, kwăbe, kwăba, kwăbo, see hinder.

reproach, n. zargi, zagi. reproach, tr. v. yin zagi, bache.

reproaching, zagi, zage. reproof, n. foro ; harasa, rarauka (K.).

reprove, tr. v. yin foro.

reptile, n. mai-rurrafe, pl. masu-rarrafe, abin kasa, igiyar kiasa.

reputation, n. yabo, suna, e.g. his r. spread throughout the Sudan mutane duka su ji sunansa chikin Sudan. requital, n. fansa, pansa, hansa, saka-mako. requite, tr. v. biya; (in a bad as well as good sense) rama. rescue, tr. v. liwache or kuashe; see also deliver.

resemble, to daidaiche, yin kama.

reserve, (i.e. support in war) ribadi.

reside, intr. v., see dwell. resign, tr. v. (to give up, 
abaudon) bari, bar; to $\mathrm{r}$. office maida rawani.

resignation, n. hankuri, hankura, haḳura, hakuri.

resigned, to be, v. jin sanyi, also hankuri with $y i$ or the forms in $n a$, e.g. I am r. to this ina hankuri da wannan; he was r. to this pain ya $y i$ hankuri da azaban nan.

resist, tr. v. (gen. to withstand, baffle) hana ; to r., request etc. hana q.v., ki $i j$, e.g. he resisted every proposal ya ki ji magana duka.

resistance, $n$. in sense of prec. init. hanawa, makawa.

resolution, (i.e. firmness) $h a$ rama, hazama.

respect, n. (i.e. esteem) hasafi, kauna.

respond, v. (to answer) amsa, yin amsa.

rest, n. 1. (remainder) shawara, saura, kingi, shingi (K.).

2. (repose, quiet) füta, fütu, futcwa, hutawa, mugāma*, cf. repose; (of the grave) place of r. makwanchi; (of death) the last r. makarin barchi.

rest, r. 1. tr. (to lay, place) aje, $s a$, e.g. he rested his hands on the book ya sa hannuwansa bisa litafi.

2. intr. (to be at rest) futa, fucha, yin mugāma; (to be laid, placed) pass. of aje, $s a$.

resting-place, n. (lodging) măshidi; his last resting-place makwanchinsa.

restitution, make, v. rama.

restive, be, intr. v. yin tuma.

restlessness, kiriniya.

restore, tr. v. 1. (to give or bring

back) maida, mayas, kwanda, ramka, bayas da.

2. (to make good) rama.

3. (to r. to life) raya; (to

be restored to life) rayu.

4. (to renew) sabunta.

restrain, tr. v. hăna, kwăbe, kwăba, kwăbo, tsère; see hinder.

result, n. akiba.

resurrection, n. tashi daga matattu, tayaswa, kiyāma ; the r. day ranan gobe (lit. the day of to-morrow), ran gobe, ranal (or ranan) kiyama; periphr. the day when the sounder of the trumpet shall sound ranad da mai-busa ya busa ḳafo $n a s a$.

retail, a r. seller of corn dan kwarami,mai-sari ${ }^{*}$; retailers yan shimfidu.

retain, tr. v. rike, rika, riki* retained, particip. rikakke, fem. riḳaḳiya, pl. riḳakku. 
retainer, to become a r. of yin chaffa (or chappa). retaliate, intr. v. rama, saka, see revenge.

retaliation, n. (in a good as well as bad sense) saka-mako; see requital.

retch, to yūokŭra. retching, n. yūnkŭri. retire, to $r$. into shelter noke.

retreat, to ja da baya. return, n. dawaya.

return, intr. v. koma; to r. to where the speaker is, to $r$. here komo, dawo, dawayo; to r. from a place dawaya; to r., tr. v. mayas da, mayar da.

returning, n. (of place) komawa, kome, pl. kome-kome; (of state, = a changing back, reversion) juyawa, waiwaiyawa.

reveal, tr. v. găya, waye, runa, e.g. they revealed the secret to the king sun găya asirin nan ga sariki.

revenge, n. fansa, pansa, hansa, ramuwa, tarna.

revenge, v. rāma, zoje; see requite.

revere, tr. v. ; cf. seq. reverence, n. kwarjini.

reverence, tr. v. tsarkaka, tsarkaki, charkaka and, in freer sense (= to honour) girmama, and bada girma. revile, tr. v. yin zagi, fallasa or pallasa, kwăla. reviling, zage, zagi. revive, intr. v. (as from fainting) farko.

revolt, n. tawaye.

revolt, to lanka shappa, yin

tawaye.

reward, n. lada, akiba. reward, tr. v., see requite. rhinoceros, n. kilifori, kilhore (a Fullani word), karkanda*. rib, n. awoza, awaza (S.), pl. awazu, awazai; ribs coll. hakarḳari.

rice, n. shinkafa, more particularly $=r$. in the husk; husked, clean r. shinkafa, sanshera, surfaffe, gŭmi; tuft of r. geza, pl. gezuna; the swelling of $r$. when boiled auki, abki; a soft mash of r. fate-fate; a mixture of r., milk and honey gumba; a cake made of $r$. and guinea-corn masa; a cake made of r., oil and honey tsatsafa; a large ricebag saulo; ' hungry' r. acha; a dark coloured kind of $r$. jimero* ; r. husks (used for washing ink off writing boards) buntu, shēfe.

rich, adj. 1. (wealthy, also 
concr., a r. man) mai-dukiya, maneadachi, pl. mawadata.

2. (abundant) dayawa.

3. (splendid as ' $r$. dress') na ado, fem. ta ado.

rich, to be, intr. v. tajarta, ajar.. ta, wadata, walata, yalwata. riches, coll. dukiya, pl. dukoki or dukiyoyi, wada, wadachi, arziki, ajiya, ătajirchi, tajirchi, falala, gatanchi.

riddle, n. marauchi, zauranche. ride, intr. v., express by periphr., e.g. he was riding along yana tafe bisa doki; I rode to the town na hau doki na tafi gari; spec. to r. at a gallop sukuwa (Kano), suka (Sokoto), sukane, sukwane; tor. for exercise kilisa. rider, n. mai-doki, pl. masudoki, mahayi; an expert r. gwanin doki.

ridge, n. kokuwa; a ridge in a field kunya, coll. kwiya (S.), kadada.

cidicule, tr. r. dāra, shamata; he turned him into r. ya ba shi dariya.

ciding, zaman sirdi; a place for $\mathrm{r}$. in fagen doki; a place for riding in at the gallop masukwani.

fight, n. 1. gen. gaskiya.

2. (authority or privilege) iko, pl. ikoki, inganchi.
3. (claim) alhaki; to be in the r. in a dispute hujunta.

4. (the opposite of left) dama.

right, adj. 1. (in conformity with truth and justice) da gaskiya, da gaske, or simply gaskiya, nakwarai*, àdili; to be $\mathrm{r}$. inganta, ingata, see also lawful, proper.

2. (opposed to left) nadrma, fem. ta-dama; the $\mathrm{r}$. hand (i.e. the bodily member) hanru na dama; the $\mathrm{r}$. side wajen dama.

righteousness, n. adilchi. rightly, adv.(truthfully, justly) da gaskiya, da gaske.

2. (correctly, exactly) kwarai, sarai, e.g. if $\mathrm{I} r$. understand you will come to this house in the evening idan na ji kwarai za ku zo gidanga da mareche; he did not count them r. bai kilga su sarai ba.

rind, n. fāta, pāta, bawo, bawa. ring, n. zobe; seal r., signet r. zoben shaida; finger r. kawainya; a metal r. placed round the hands and legs of women karafa, chakankami; a r. put through a man's lower lip baibayi* ; a leather r. worn as a charm 
on the wrist kŭmbu, kŭmbuua, see kărau.

rings, coll. arm r. mundaye;

foot r. mundayen lafa.

ringworm, makèro, kyyazbi

(K.), kyasfi (S.).

rinse, tr. v. darwaye, darwaya. rip, tr. v. keta, participial $\mathrm{n}$.

ketuwa, ketawa; see tear. ripe, adj. nuna, nina (S.) or

nunanne, pl. nunannu.

ripe, to be, intr. v. ň̆na (S.),

nŭna (K.), yin tābo; to be over-r. kosa.

ripeness, tābo, tafshi, tabshi, tapshi*.

rise, n., of a fish bulma, burma; of a star keto.

rise, intr. v. tashi; to cause to r. tashe; to r. up taso, gusa, gulgusa, gurgusa; to r. up against yin firmaki; to $\mathrm{r}$. high (of the sun) karu; to r. (to swell, of anything cooking or fermenting) yin auki or yin abki.

rising, participial n. tashi, tasawa; tayaswa is used in sense of resurrection.

risk, n., he ran a great 1. ya sha hătsari dayawa.

rivalry, n. kishi, gāsa, hamiya. river, n. ruwa, pl. ruwaye, e.g. the 1. Benué ruwan tsada; gulbi, pl. gulabe, tabki, tapki or tafki; a large r. $\operatorname{kog} i, \mathrm{pl}$. $\operatorname{kog} u n a, \operatorname{kog} i n a$ or $\operatorname{kog} a i$; the r. of paradise kausara and alkausara.

river-horse, hippopotamus, n. dorina, pl. dorinnai.

rivers, confluence of, n. magaingami.

road, n. hanya, haya*, pl. hanyoyi, būbe, godabe, tafarki, pl. tafarkoki, turba, pl. turbobi; on the r. (travelling) chikin tafiya; he is on the r. yana tafiya; do you know your $r$. from this point? ka sani hanya daga nan ko? a broad r. godabe, rimdi, karabka, karauka (S.); a hedged $r$. between farms used by cattle burtali.

roads, $n$. branching off of $r$. (pl. of kurasfa) kwasfofi; dividing of r. laloki, loloki, pl. lulokai ; meeting-point of two or more r. mararrabin hanya.

roar, n. kugi, tsawa; r. of a lion gumza.

roar, intr. v. yin tsawa, yin kugi, yin kuka; (of camel, donkey, fire, etc.) yin ruvi. roast, tr. v. soya or suya, bandata, găsa, the last used with gurasa bread. roasted, particip. gasashshe; fem. gasashshiya, pl. gasassu. roasting, banda, găshi. 
rob, tr. v. (to take openly, by force) kwache.

robber, n., one who robs openly mai-sane; a highway r. (brigand) măfashi, mai-fashe, $\mathrm{pl}$. măfasa.

robbery (with violence), parmaki.

robe, n. riga, pl. riguna; splendid robes riguna na ado; silken robes riguna na alharini.

robe, tr. v. sa (lit. put on), e.g. they shall be robed in white a sa ma su riguna farfaru.

rock, n. dutsi, pl. duwatsu, duchi, falcle, fa, pa.

rock, tr. v. (to shake or swing to and fro) reta, yin reto.

rock-salt, n. gallo.

rod, n. sanda, pl. sanduna.

rogue, n. mazambache maizambata.

roll, v. 1. (to move along by turning over and over) tr. bingira, mirgina, mirgine, layăta, layache, yin birgima; intr. to r. down gangara or gangari; to r. away gangarad da.

2 . (to fold round on itself) tr. năde; to r. together or up năde; to r. up kalmăsa or kalmashe; to r. up, e.g. a covering of a doorway, or a piece of cloth etc. linke, ninke; to r. into balls as clay for building chibra, tsibra, chura, dunkula; intr. and reflexive to $r$. up or together nadu.

roller, (bird) tsanwaka.

roller, i.e. a stone used for crushing rice etc., n. dan maguriji.

rolling, particip. n. birgima: r. downgangarawa and gangaro. roof, n. jinka; the following apply to the native thatched roofs ; the centre of 1 . kwando; the conical grass top of a r. boto; a beain to support a r. dirka; a binding line inside $r$. formed of two or three reeds mirdaka, murdaka; a band of grass rope outside a $r$. jiniya; an arched r. damrenguga, dauren-guga; an oblong r. bakan-gizo; to bind grass with cords so as to form a $\mathrm{r}$. yamche or yamchi, yin kandama; the plaited mat-work which acts as the keystone of a conical r. kirinya; the horizontal ties of grass which bind the sloping rafters of a r. $\operatorname{tanka;}$ the sticks which slope from the upright poles of a r. to the cross piece (mafyadi) tsaiko; the cross pieces tied to the sloping sticks (tsaiko) for the grass 
of the r. to rest upon karan tanka; the sticks placed in a $r$. to prevent the grass from slipping down kini; the highest part of the inside of a r. kwankuwa, kokuwa; a cross piece of wood which rests on two $(g \circ f a)$ sticks and supports the r. of a house mafyadi; the apex of a r. kan daki; house with flat r. soro; upper storey of such a house soron bene; a flat mud r. rufi.

room, n. 1. open, unoccupied space in any sense sarari; unoccupied space on a flat surface as a plain, a floor fili, e.g. there was no r. for (putting down) my load babu fili ga kayana, ef. seq.

2. an apartment or $r$. in a house däki, pl. dakuna; a private sleeping r. baraya (S.); an upper r. in a twostoreyed house, bene; a small dark r. loloki, laloki, pl. lolokai or lalokaye; a r. made of mud and thatched with reeds tsaiko.

room, to have plenty of $r$. to sit down, intr. v. wala.

roomy, adj. mai-sarari, da sarari, e.g. this chamber is r. dakin nan yana da sarari. root, n. (of vegetables, etc.) saiwa (K.), saye (S.), p]. sayu, sauya (Kats.) ; r. of a tree $t \bar{u} s h i$.

rope, n. gen. igiya, pl. igiyoyi, yagiya (S.) ; to plait a r. tumka (S.) or tukka (K.) igiya; spec. of various uses and materials : a r. for hobbling horse tarnaki, dangwali, dabaibayi (K.), dabaibiya (S.); a r. for leading a horse ăsalwayi ; a r. halter for horses or camels răgama; a r. (also coll.) tied to anything, e.g. to a rafter ragaya; a r. tying a horse's leg to a post gindi; a r. for tying up a camel ăkala ; a r. fastened between two posts to which animals are tied rande; a r. used for tying a thief kogawa; a twisted hide r. Kiri, pl. kirra; materials for $\mathbf{r}$. (plaited grass, palm leaves, fibre) tsaiwa; leaves and fibre from a large species of palm for r. $k a b a$, yadiya; a fibre for making $r$. yawa; a reed-like plant (Hibiscus cannabinus) for making $r$. which is called by the same name rama; a $\mathrm{r}$. made of rama, tamagi, tamagye; a large tree from the bark of which small ropes are made tawatsa; a trailing $\mathrm{r}$. plant kuranga, see also raba. 
rosewood, African r. madobiya.

rot, intr. v. (to putrefy) riba, ruba; (to go bad) bache. rote, by, 1. n., saying by r. tulawa.

2. v., to say by 1. yin tulawa; to learn so as to say by r. (by heart) samu harda.

rotten, particip. adj. (of fruit, etc.) rubabbe, fem. rubabbiya, pl. rubaḅbu, (of corn) tsadari, gen. batache, fem. batachiya, pl. batattu, a lalache; to become r. rŭba, riba.

rough, adj. da kaushi, da kurzunu.

roughness, n. (unevenness of surface) kaushi, kurzunu ; r. of skin kaushin jiki.

round, adj. express by the nouns $=\mathrm{a}$ r. object chǔbiri, kumbu, kawanya (K.), e.g. a r. piece of mud chǐbirin lasas ; to make r. chîbra; to cut r. shan kumbu; v., to go r. dauraro, zaga, gewaya, kewaya, jiwaya, kewaye, kewayo, kewayi, the last also tr., e.g. they went r. the city sun kewaye birni; bülo or bullo; to go r. zāge, zāga, zwage (S.), zāgi; to go r. in order to examine a thing gewaya or jewaya; to look r. dauraro; prep. kewaye, e.g. they made a road $r$. the pool sun gina hanya kewayen tabki; the storm is going r. over there hadari yaиa zagawa.

rouse, tr. v. (to make rise, e.g. from the ground or from sleep) tashe, tayas, falkad $d a$. rout, n. kāshi, to put to $\mathrm{r}$. bada kāshi.

row, n. (series, line, rank) săf $u$, jeri; to form a r. yin săfu; in a r. a jere; to lay out in rows tsāra, tsāre.

row, n. (angry dispute), see dispute, quarrel; (noisy outcry) leururuua.

row, tr. and intr. v. tuka, yin tuka (lit. to push, or propel). Hausas acquainted with European oared boats employ this word which is the term used for 'paddling' native canoes.

royal, adj. na-sariki, fem. tasariki; r. officers or attendants fadawa, q.v.

rub, tr. v. faje, yāfa and yä́to, săba, chuda; to r. (or grind) corn tushe; to r. anything, e.g. corn in the hands murje, murda, mulmula, murtsuka; to $r$. the back of a knife backwards and forwards $d \bar{a}$ dara; to $r$. the hair off a 
hide or skin jemi; to r. out or erase shafe, yin maimai ; to r. smooth chudanya, darje.

rubbed, particip. adj. murjaje; murtsukakke, fem. murtsukakka, pl. murtsukakku.

rubber, n. 1. (e.g. a cloth, used for rubbing or wiping) abin shafe.

2. (india-rubber) danḳo, dankon gamji, alibida ; rubber-vine chiwo, chuwo ; indiarubber trees yamji, ganji (K.), cf. durumi, baure, bore (S.), chediya, kawuri, wa, taba-ni-kasamu.

ruby, n. yakutu*

rudder, paddle used as a, n. matuki.

rug, a woollen sleeping r., n. kilishi.

ruin, tr. v., to spoil, destroy lata; to be ruined or to fall into $r$. (of a house, etc.) roshe, rushi; participial n. and pres. form rushewa.

ruins, coll. (of a place, town) kufai, pl. kufaifai, kofai, kango; falling into r. $r u$ shewa.

rule, n., government, royal sway sarauta; an established mode of procedure tada, pl. tadodi, ada, kaida.

rule, v. (to hold sway as a king) mallaka, mallaki, mallake, yin sarauta, chude, umarche; (tc decide, order authoritatively' hukumta, e.g. he ruled that we should do this ya hukumta mu yi haka.

ruler, n. mai-mallaka, masarauchi, mahukumchi, hākimi, pl. hakimai; (king) sarki or sariki, pl. sarakuna or sara. kai.

rumour, rigima, waiwai.

run, intr. v. gudu; (to melt) narku; to r. away gudu, guje, tsire; to r. away quickly sheka; to outrun tsire; to r. out (to come to an end) kare; of water, to r. over (to overflow) tuda, tude; at a r. a guje; the following expres. sions are used to denote to r. fast zura da gudu, sheka da gudu, karta da gudu, fashe da gudu, tantala da gudu, gudu kar, ruga da gudu; running away tawaga. runaway, n. 1. (of slaves) gujajje, pl. gudaddu.

2. (in war) maguji or muguji.

runner, a r. in front of a horse gurguri, zagi. rush, intr. v. kutsa; to r., e.g. out of a crowd ruza. rust, n. tsatsa. rust, intr. v. yin tsatsa. 
custling, e.g. of wind in trees kaya-kaya; r. of grass sǔkunsǔkun.

sabbath, n. 1. (in the scriptural sense = Saturday) assabat, assibit, ranan assabat.

2. (Sunday) lahadi, ranan lahadi.

sabre, n., see sword.

sack, n., a largeskins. or bag for cowries ǰ̌ka, jǔkka, pl. jikkuna, kwasubro, buhu (Z.), birgami, buigame these are not used as water skins for which see under skin; a skin s. for loading camels, donkeys, etc. waga, kyankyandi, gurara, kaiwa*; a s. made of network raga, pl. ragogi; a large s. of salt (one donkey load) lange, pl. langaye, see bag.

ack, tr. v. (to pillage or plunder a place or town) kwache, e.g. he took and sacked the town ya chi garin nan ya kwache dukiyassu duka.

ack, (of a town) n. buruntu. acred, adj. (connected with religion) na addini, fem. $t a$ addini, e.g. honour s. things and do not ridicule them $k u$ girmama abubuwa na addini kada ku ba su dariya; (holy, pure) tsarki. sacrifice, n. sadaka*, laiya. sad, adj. (depressed, sorrowful); to be s., see sadness; a s. business (causing sorrow or pity) abin tausayi ; a s. business (i.e. bad, wicked) abin mugu.

saddle, n. sirdi, pl. siräde and sirluna, siradda or sirdodi, bukuru, bakuru*; a native s. cloth which is laid on the s. jẹlala, lappa, labba, kafu (S.), mashimfidi; a s. peak kwaclizya, that in front kwachiyar găba, that behind (the cantle) kwachiyar băya; stuffing or panels of a s. zubuka, zabuka; a pack s. with pockets for water pots, etc. mangala; a s. embroidered in gold or silver talha; crupper of a s. jabaya, jakuturi; the leather thong attached to a s. and passed through the ring of the girth kaitara, kaitaro ; ornamental s. Haps zaggin sirdi; a s. of meat takandar nama.

saddle, v. (of camels, etc.) labda, (of horses) damve or darme (S.), sirdi, yin sirdi.

sadness, n. bakin zuchiya; to experience s., to feel sad $j i n$, yin or the forms in "a with the n., e.g. I experience s., . I feel sad ina bakin zuchiya. 
safe, adj., s. from peril amintache, pl. amintattu.

safe conduct, letter of, $\mathbf{n}$. watikal lamuni.

safety, n. (security from harm) lamuni, amana; (deliverance from harm) chira, tsiras, chiraro, tsiraro.

sagacious, adj. da basira, da hankali, mai-hankali.

sagacity, n. basira, hankali.

Sahara, Hamada.

said, it is, determinative or causal phr. wai, e.g. thon art proud because it is s., Thou excellest all kana kumburawa wai ka fi kowa.

saint, (fakir) wali, waliyi, pl. waliyai.

sake, for the s. of, prep. domin, don, garin, sabad da, sabado* or saboda*, e.g. for his s. dominsa, sabili da shi; for the s. of this domin (or don) haka; for the s. of a walk garin yawo; for the $s$. of what? domin mi, don mi, dommi, and sabad da mi.

sale, to expose for s. talla; it is on s., it is for s. a sayas $d a$; on s. sayaru:a, saisuwa; a cheap s. gwanjo; the exhibition of goods for s. kōli; s. on approval chinikin shawara; a s. under a guarantee $u d a^{*} ; \mathrm{a}$ s. in which the buyer is allowed time ti decide whether he will accept the offer remaining oper chinikin zabi.

saleableness, sayuwa.

salesman, n. mai-saida, dar kasuwa.

saline, adj. da gishiri, nє gishiri.

saliva, n. sallabi, miyau, ya (K.), dululu.

salmon, fish resembling, $\mathrm{n}$ faliya.

salt, n. gishiri; prov. a mas may boil horns with his ow s. (i.e. one may do what on likes with one's own) mutun da gishirinsa shi kan dafi lafo; spec. a dark kind 0 s. manda; a s. brough from Asbeu, beza; black s from Bornu manda; har rock s. gallo; an inferio. kind of s. balma; a s. $(0$ natron) used in dyeing as : mordant, also used medi cinally ashauma, ashoma; cake of s. foche, fochen gishir mangul; round flat piece of s. coll. aserimi* ; a load 0 s. cut small bakan gishiri; pyramidal load of s. kantu; small kantu of inferior s. pash a large kantu of s. azurumi a wood ash from which s. i obtained zăkanko*. 
alt-bag, n., long, narrow b. for carrying s. lange, langi; a small s.-bag chukurufa*. altless, adj. babu gishiri; spec. of anything eaten without salt (insipid) da lami.

altness, (brackishness) zartsi. altpetre, n. kanwa; spec. s. used medicinally jan kan$w a$.

alutation, n. gaisuwa, e.g. he paid no heed to my s. bai kula ba da gaisuwata or $b a$ ya karḅa gaisuwata ba; a $\mathrm{s}$. addressed to an important person ingwayya, ungwaiya; a public s. mubaya. The language is rich in expressions of s., e.g. s. to you (Engl. hail! welcome!) pass. a gaishe $(-k a,-k i)-k u$, a tuski; the comrnonest expr. of s. is sanu or rep. sanu sanu and this is most frequently accompanied by a reference to the time of day, or the state and occupation of the person saluted, e.g. good morning (lit. s. to you in the morning) sanu $d a$ safe, good evening sanu da mareche, welcome out of the rain sanu da ruwa; s. to you in your bereavement sanu da kewa; s. to you at your play sanu da wargi; s. to you at your work sanu $d a$ aiki or sanu da aikinku or sanunku da aiki; spec. s. (among moslems) salam; shaking a spear or hand in s. jafi (S.); see also jinjina.

salute, tr. v. gaida, gaishe, gaisa, jinjini, e.g. I saluted the man na gaida mutum; spec. to go to s. (of sacred persons or places) ziyara; to s. several persons in turn gaggaishe.

salvation, n. tsīra, tsīraro, cheto.

same, adj. daya (lit. one), e.g. they are the s. duk daya ne; this is the $\mathrm{s}$. as that wannan daya kaman wanchan; together at the s. time or place gaba dai or gaba daya; the s. hakanan; as a determinative employ demonstrative pronouns, e.g. I saw the s. man yesterday in the market $n a$ gani wannan (or wannan mutum or mutumen nan) jiya chǐkin kasuwa.

sanctify, tr. v. tsarkaka, tsarkaki.

sand, n. rairai, rerai, jiggawa or jigawa; spec. fine s. turbaya, turda (S.); white s. in water yashi; grains of $\mathbf{s}$. barbadi; s. mixed with grain tarke. 
sandal, n. takalmi, pl. takalma, kufita, kufita, kupta, pl. kufitai or kufutai; sandals with red leather tops and hole for toe sambatsai; a light kind of decorated s. tajawankai. sand-fly, filfilwa, fiffilwa, kiyashi, kyashi, kyafirfita. sand-grouse, kwantatoyi, bar$u: a$, ladin rogo.

sand-hill, a, n. jiggawa, jigawa. sand-piper, shärafage (S.).

sangar, shirgiya.

sarcasm, gatse.

sasswood, gwaska.

Satan, pr. n. Shaitan, Shetan or Shaitani.

satchel, n. (leathern) găfaka, lăki.

satin, talashi*, antalashi. satisfaction, n. 1. (of the appetite) koshi.

2. (of the feelings and emotions) dadi, e.g. we felt great s. mun ji dadi dayawa.

3 . see requite.

satisfactory, it is, phr. ya yi. satisfied, to be, intr. v. (of the appetites) koshi, yin koshi, e.g. they ate, they drank and were s. sun chi sun sha sun koshi; (of the emotions) jin dadi ; cf. seq.

satisfied, a being, n. koshi; one who is s., n. kosashe, pl. kosassu. satisfy, tr. v. (of the appetite) kosad da; (to pay claims, etc.) biya, rama.

Saturday, pr. n. of time ăsabat, assabat, ăsabar, ăssibit, ranan assabat.

sauce, n. miya*.

sauciness, taurin ido.

sausage-tree, rahaina.

saunter, to ragaiche, see idle. saunterer, mai-ragaita.

savage, n. (barbarians, uncivilised human beings) baibayi, pl. baibai, babbawa or baubawa.

savage, adj. (barbarian), cf. prec., (cruel) da muni.

savagery, n. (cruelty) muni, zafin rai, keta.

save, tr. v. 1. (to rescue, deliver) chira, chire, chiro or tsirus da, tsarda (K.), tsarshe, tsaras da (Daura), tsirad da, cheche.

2. (of money = to lay by or up) aje.

save, exceptive prep. sai, see but 2 .

saved, to be, intr. v. chira, tsira.

saviour, n. mai-cheto, machechi, pl. macheta.

savoury, adj. gardi, fem. gailiya, da gardi, da zaki; for the opposite quality see insipid. 
əw, n. zarto, sassaka, sasago*, magāgări

aw, to $g \bar{a} g \breve{a r} a$.

awdust, dauso.

ay, tr. v. che with pres. forms chewa, fădi, făda, tăne*, e.g. what do you say? mi ka che? we are saying muna chewa; it is said an che, aka che; he said to them ya che da su, ya fădi ma su; he says, it is said, they s. (used to determine a phr. or clause as uttered or admitted to be true by others, like Engl. fam. 'you know') wai; s. a thing over again tusa; to s. off by heart or rote yin tulawa. aying, n. 1. (something said) magana, pl. maganganu; (a popular s.) sara.

2. participial n. (act of s.) chewa used with pres. forms in $n a$.

cab, n. k̦urji, pl. ḳuraraji, kuraje; also kirchi, gurje, bamḅaroki, gyambo; a s. which has healed up tambo; scabs coll. balli-balli.

cald, tr. v. (i.e. with hot water) sale (K.), swale (S.). icale, n. (as lichen, dandruff) toto, tautau.

scale, to s. a fish kankale, kankare.

scales, n. 1. (of fish) kumba, pl. kumbuna, kumbabi or kumbai, fofon kifi; (of dead alligator) kirgin kăda.

2. (balance) maauna, maauni, magwaji, mizani, magwadi.

scan, v. (to look at with scrutiny) yir kallo, e.g. we walked about scanning everything mun yi yawo muna kallon dukachin abu.

scandal, tségumi, pl. tsegunguma; one who spreads s. mai-tsēgumi, mai-tsēgunchi.

scar, n. (cicatrix) tabo, tambo, kŭfa; scars balli-balli; scars made on face serving as tribal marks shaushawa; see marks.

scatter, v. 1. tr. watsa, wache, watsar da, barbada, walwanche, warwache, warvutsa, rarraba or rarrabi.

2. intr. watse; they scattered or were scattered an watse su.

scattered, particip. pass.watsu. scattering, barbaduwa, kachakacha.

scent, n. 1. (characteristic odour of animals) wari, cf. seq.

2. (a sweet or agreeable odour) ḳamshi, kanshi, ł̣amsa, turare, wardi; a plant the root of which furnishes a s. jiji. 
scent, tr. v. (to recognise by the odour) jin wari; the dog scented the lion kare ya ji warin zaki.

scent-bottle, n. wakiya, wakiyya.

scented, keen-, adj. (of hounds) mai-jin wari.

scheme, $\mathbf{n}$. (artful contrivance) wayo, wayau.

scholar, n. (a great scholar or teacher) mālam, mālami, pl. malamai; masăni, pl. masana; (a pupil) almajiri, pl. almajirai, dan makaranta, makoyi, makoyi, makaranchi; (used adjectively =: learned), maikaratu.

school, n. makaranta.

scissors, n. almakashi; joint of s. gwarmi, kwarmi, pl. kwarmu.

scoff at, to, v. $b a^{\prime} a$ and yin $b a^{\prime} a$. scold, v. yin tsawa, buga tsawa, tsawata $d a$, e.g. he scolded her well ya yi ma ta tsawa dayawa.

scold, a, mai-fütina.

scorch, tr. v. farcha, yin farsa. score, n., of numberlăso, hauya, the latter is esp. used in counting cowries, e.g. he looses two thousand cowries ya bar hauya dari.

scores, to pay off s. rama gaya. scorn, n. gaya, ba'a, bananchi. scorn, v. rena, see despise. scorpion, n. kunāma, pl. ku namomi or kunamai, duwu munumunu.

scourge, n. bulala. scourge, tr. v. yin bulala. scout, n. majewayi, see spy. scowl, intr. v. damre fuska. scramble for anything, v wasashe, wawashe, yasash (S.).

scrambling, wasoso. scrape, tr. v. karkari, (to clean and so polish) gogi o goge, fafe, kwarzane, e.g. h is scraping the axe-handl shina gogewa bakin gatari to s. or s. out rede, tuji tuttuje; to s. up or grub ur e.g. ronts tona, tone; to : out a dish sude.

scraper, a gurzago, gurjago

a s. used in dressing leathe kartaje.

scrapings, e.g. of a dish sudi scratch, tr. v. yin susa, yi $z u z a$, yin farta, gurza, ya yaga; to s. up with the nai] karche, kwarzane.

scratching, susa.

scream, n. ihu, ifuuc, ufi kurūruwa, tsuwa.

scream, intr. v. yin if $u, y i$ tsuwa.

screw, v., to s. up the eye rumchi, rumtse. 
scribe, marubuchi, pl. marubuta.

scum, n. kunfa, kumfa, yana; s. from molten lead käshintăma.

sea, n. gulbi*, kogi*.

seal, n. zobe, zoben shaida, mazubi, hatumi, hatimi, hadufi, tambari.

seal-ring, n. zoben shaida. seam, n. (in cloth) albada, pl. albadu or albadodi, shafi, shafe, pl. shafofi or shafeshafe; spec. a breadth between seams of cloth chiki.

seamless, adj. (applied to cloth) liwasa.

sear, tr. v. (with hot iron, to cauterise) lalas, sa lalas.

search, n. chigiya, chiwirwiri, tsiwurwuri ; to make diligent s. yin chigiya, bada chigiya, b̌̀da.

search, v., to s. after or for nema, bŭda, chigita, nŭfe, nŭfi, nifa* ; to s. for with the hand lalabe, fafake; make search nema.

searching after, n. (desire and object of desire) maradi or muradi.

season, n. 1. gen. (usual or proper time) sa'a, lokachi, loto.

2. (division of the year with respect to weather, etc.) dry (and hot) s. rani; it is the dry s. ya yi rani; the hottest part of dry s., when the rains are beginning $b a$ zara; the wet s. damana, damuna, damina.

\section{seasoning, yakuwa.}

seat, n. mazamni (i.e. spot on which anyone sits), kujera, bige*, turāka (K.); a s. outside a house dakali; judgment s., also s. on which a king is carried about karaga. secede, intr. v. (to separate from, withdraw from) raba and rabu with da or daga.

second, ord. num. na-biyu, fem. ta-biyu, also na-baya, fem. ta-baya.

secrecy, asiri, ashiri*.

secret, n. boya, asiri, kara* ; in

s., see secretly.

secret, adj. na-asiri, fem. taasiri, da asiri; a s. place lalokin asiri; vv. to keep s. rufe, rufa, rufi or rife, $k a-$ rata*; to make s. or to discuss secretly asirta; to talk secrets yin gāna.

secretly, adv. da asiri, a boye; see prec.

section, n. gedawa*. secure, adj., see safety. secure, tr. v. (from danger, harm, etc.), see guard, (fam. to catch, capture, e.g. a prisoner) kama, (to guarantee 
payment of a debt, etc.) see seq.

security, u. 1. (part payment of a debt as s., earnest money) amāna.

2. (a thing left as s., a pledge) jingina.

3. (responsibility for a debt, etc. $=$ guarantee) $l a$ muni, taulahi, tallafi; I stood or went s. na yi lamuni.

sedge, fragrant s. kajiji; wild s. dan tunuga, gemen kusu, aya aya.

sediment, n. gwiba, guibi or guibi.

seduce, tr. v. farke, rude, bāshe.

see, tr. v. gani, gario, often contracted to gan, e.g. I saw her na gan $t a$, also to $g \bar{a}$ which is very commonly used as an imperative, e.g. s. him, or s. here ga shi, yani is also used in a pregnant sense to perceive, recognise, understand; to s. from afar tsinkaya, tsinkayi, hango.

seed, n. gen. (of plants, men, creatures) iri, pl. irare, iriiri; spec. seeds crowded together gurguzu, gurgusu. seedling, shuka, shukakke. seeing, participial n. ganewa. seek, tr. v. (to search for) nema, bìla, e.g. wait till you are sought for sai am bide ka; to s. after (often implying to set the heart upon) dawainiya; to $\mathrm{s}$. again zobe; to $\mathrm{s}$. for tuski, tuske; pregn. s. and return with b̌̆do, e.g. let her be sought and brought here, a bido $t a$; to go to s. and return with nemo.

seen, pass. particip. gananne, fem. gananiya, pl. ganannu. segment, e.g. of a kola-nut azara (Z.), bare (K.).

seize, tr. v. (to lay hold of) $k \bar{a} m a$, intens. kankama, make; to s. (esp. in order to eat) rida; to s. forcibly as in war yin buruntu, kwache ; (to snatch) amshi; to s. and bring kankamo ; to s. in the arms $d a$ dume; to s. a person by the collar dagume.

select, tr. v. zaba, zabe, zabii*, wari, the last often used of choosing out one or more pieces.

selected, pass. particip. $z a-$ babbe, fem. zababba, pl. $\approx \alpha-$ babbu.

self, n. expressed by kai and rai with possess. pronouns, I . myself ni da kaina, ni kaina, also less commonly ni raina and raina.

selfishness, kurmusu*. self-laudation, n. kirari. 
sell,-- tr. v. sayas, sayar, and when followed by an object saida or sayas da, saishe, sawo, talla; the last also esp. of having or exposing on or for sale, e.g. good camels are to-day selling in the market rakumma nagargaru ana sayar da su yau chikin kasuwa; in the sense of consenting to s. the pass. of sallama is often used, e.g. I agree to $\mathrm{s}$. = I let it go or you can have it a sallame shi; it is unsaleable ya ki sayuwa.

seller, n. mai-saida, pl. masusaida.

selling, saisuwa, buying and s. saya da sayarwa.

send, tr. v. aika, aike, which also = to s. forth, from or to ; to $\mathrm{s}$. to where the speaker is aiko, (with a person only as obj., lit. to rouse up, to start) $t \bar{a} d a$, e.g. I sent a messenger na tāda manzo; to s. back mayas da, mayar da, yarda; to s. away tayas da; to cast, throw, e.g. a bullet jefa.

sending, n. aike.

senna, n. filasko*.

sense, n. 1. (i.e. good s., understanding) hankali; a man of s. mutum maihankali. 2.(signification) see meaning.

senseless, adj. (stupid, foolish) maras-hankali, magagachi; (insensible, unconscious) see seq.

senses, n. (the faculties of sensation) hankali, e.g. he is in a faint and senseless but in a little while he will come to his s. again shina suma hankalinsa kuwa ya bache amma jima kadan hankalinsa zai komo kuma gare shi.

sensible, adj. (prudent, intelligent) mai-hankali.

sensibly, adv. (with good sense) da hankali.

sent, pass. particip. aikakke, fem. aikakka, pl. aikakku; one s., n. ma-aika, manzo; spec. one s. from God rasulu* sentence, n. (judicial decision) shari'a; to pass s. yin shari'a. sentinel, n. gāta, pl. gataye, bage.

sentry, n., see prec.

sentry-post, mabăga (S.). separate, adj. bambam, akebe, e.g. s. from that bambam daga wanchan.

separate, v. 1. tr. răba and răbi*, rabda, rabshe, kēbe, kebanche, kebanta, wāre.

2. intr. răbu; to s. from zau$d a^{*}$; separating bambaruwa. 
separated, pass. particip. ra$b a b b e$, fem. rababba, pl. rababbu.

separately, adv. dăki dăki. separation, n. răbo, răbuwa, baran-baran.

serene, adj., see calm, clear, quiet.

serious, cf. the matter has become s. magana ta bunk̄āsa. serjeant, saje*. sermon, n. wa'azi. serpent, n., see snake. serval-cat, rabji, rabbi.

servant, n. (not slave) băra, fem. băranya or barainya, pl. bărori and pl. of multitude băruwa or barwa, which implies a large number such as a king would have, dan daki; a female s. maaikiya ; s. of God bawan Allah (lit. slave of God).

serve, v. 1. (of one not a slave) yin barantăka.

2. (of a slave) yin bauta; this is also the proper term (as the more respectful) for to s. God or to s. false gods. service, n. 1. gen. $i b \bar{a} d a$.

2. (of one not a slave) barantăka, that of a slave being bauta (servitude, slavery), hence its use as given in prec. 2.

3. (relig.) s. of God $i b \bar{a} d a$; concr. divine s. (public worship) salla.

servitude, n., see slavery.

sesame, n. ridi, lidi.

set, tr. v. (gen. to place) $s \bar{a}$; intr. (of the sun) fadi, e.g. the sun s. rana ta fadi; combinations of to $s$. with particles, etc. are : to s. apart from raba, to s. aside (to reject) $k i$, to $\mathrm{s}$. aside (to omit for the present) bari, bar; to s. by and to s. down (e.g. on the ground) aje; to s. forth (to exhibit, state) gaya; to s. up tayas, kafa, to s. upon (to assault) yin firmaki; he is s. upon ana yi da shi. setting, the s. of a fractured limb dori; a bone setter mai-dori.

settle, v. 1. tr. (gen. to arrange, set right) gyara; (to pay, liquidate) biya, e.g. I settled the debt na biya bashi; he settled the dispute ya raba gardama.

2. intr. (to alight, or to fix one's habitation or stay) sauka.

seven, card. num. bakwai; s. times sau baku'ai; by sevens bakwai bakwai; s. thousand saba'a.

seventeen, card. num. goma sha bakwai, sha bakwai. 
seventh, ord. num. na-bakwai, fem. ta-bakwai.

seventh, one-s. part subu'i. seventieth, ord. num. nasabaïn, fem. ta-sabaïn.

seventy, card. num. sabaïn. sew, tr. v. dumke, dunke, dum$k a$ or dumki, lāfe.

sewing, u., s. at edge of a garment tindumi; v., to darn or tack in s. yin lalabtu; s. thread mandawari.

sh!.n. (the sound of hissing) shishita.

shackle, v. $s \bar{a}$ with seq. and ma, e.g. we shackled them mun sa ma su malwa; let him be shackled a sa masa gigar. shackles, n. malwa, marwa, gigar, see also fetters.

shade, n. inuwa; a broad s. inuwa mai-fadi; to enjoy the s. of sha inuwa.

shadow, n. inuwa, e.g. a man does not leave his $\mathbf{s}$. behind him mutum bai bari ba inuwa tasa ga baya.

shake, v. 1. tr. gilgiza, girgiza, yin shillu, rauda, e.g. he shook his head ya rauda kai nasa; to $\mathrm{s}$. the head in token of assent kăda kai; to s. as in winnowing tankade, motsa; to s. off, e.g. dust kalkada, kalkade, kankade, karkade and kakkabe; to s. out wal- wache, walwanche, warwache; to $\mathrm{s}$. to and fro yin reto, yin shillu; to s. violently jijiga.

2. intr. motsa, also fig. in the wider sense of being agitated, influenced, moved, e.g. the whole multitude were shaken at the news of war taro duka ya motsa da labarin yaki; to s. (as to tremble, shiver, shudder with cold, etc.) raura.

shaken, pass. part. gilgizazze, fem. gilgizazzaya, pl. gilgizazzu.

shaking, n. (or trembling) raurawa; s. hands ban hannu, masāfĭha.

shall, aux. v. 1. (of futurity) $z a$, e.g. what s. I do now? mi za ni yi yanzu?

2. (of obligation), see must, necessary.

shallow, adj. br (or babu) zurfi, ba mai-zurfi. shambles, n. wurin fawa. shame, n. kumya (S.), kunya (K.), fulako; the parts of s. al'aura ; to feel s. jin kumya; to put to s. $s a(b a$ and $b a d a)$ kumya, kumyata, kumyache, e.g. he put him to open s. ya sa shikumya (abude or) a sarari. shameful, adj. na kumya, da kumya; a s. thing abin kumya. 
shameless, adj. da kuarkwasa, shăkìi, maras-kumya, babu kunya.

shamelessness, n. kolkosa,korkosa, shăkiyanchi, walle. shape, n. (form) kama, sifa. shape, tr.v. (tofashion, create), see make 1 .

share, n., see part, portion. share, tr. v., see divide; spec.

to invite to $s$. in one's food chuna; to s. a house tara gída; a room shared with another dakin taraiya; one who shares abokin taraiya.

sharing, (i.e. possessing in common) taraiya (K.), tarewa (S.).

sharp, adj. 1. (having a fine edge) da kaifi, da chabi.

2. (finely pointed) da tsini, mai-tsini.

sharp, to be chabe, kaifafa.

sharpen, tr. v. wāsa, yin washi, chaḅa, dāda, yin dāại, fiḳa, feḳe, kaifafa, gyarta, e.g. let this knife be sharpened a wāsa wukagga; it is sharpened ta wasu; to s. a sword koda.

sharpening, wāsli.

sharpening swords, a tool for, n. magagari.

sharper, a dan tugu.

shatter, tr. v. (intens.) farfasha or palpashe. shave, v. (with razor) aski, aske, aska, and yin aski.

shaving, verbal n., spec. s. the front of head or so as to leave only a tuft on top of head kwambe; s. one side of the head by a woman as sign of sorrow faskare; baldness caused by s. kundumi; s. the whole head or s. in two longitudinal lines each side of the crown sariya.

shavings, of wood totuwa.

shawl, made in strips, n. alkilla.

she, pers. pron. fem. 1. separate and emphatic ita, e.g. it is s. ita che.

2 . in combination with verbs $t a$, e.g. s. saw him ta gan shi, the woman said no mache ta che a'a.

shea-butter, n. dankon kadanya; the s.-b. tree kar danya; fruit of the s.-b. tree kăde.

sheaf, n. (also bundle of anything) dăme, dămi, pl.damma; spec. s. of arrows shiba*. shear, tr. v. yin sosaiye. shearing, verbal n. sausaye. sheath, n. (for knife, sword) kube.

shed, n. rumbu, rumpa, rumfa, pl. rumfuna, rinfa (K.), esp. used of a s. or booth in a 
market-place; a temporary s. bukka, pl. bukkoki, ambuta, dăbi; a cattle s. garke, garge (S.), zauren shanu. shed, tr. v. (to pour out or down) $z u b a, z u b o$; to s. tears yin hawaye.

sheep, tumkiya, pl. tumāki; a s. with two wattles hanging from lower jaw tumkiya mailawaye (or mailayu).

sheep-fold, n., see fold.

sheet, n. (of paper) taba'al takarda; a winding s. likkafani, kafan.

sheikh, shaihu.

shelf, a alkuki* ; rope supporting a s. ragaya, pl. ragayu ; a s. made with mud zaga. shell, n. (hard covering of fruit, eggs, etc.) kwasfa, kosfa, pl. kwasfofi or kosfofi, kwanso, e.g. break the nut, and peel off the s. $k a$ kariye gujiya ka bare kwasfa; s. of snails katantanwa, alkoto, alkwato, a mussel s. makan$k a v i$; s. of a tortoise kwariya (K.), kwachiya (S.).

shell, tr. v. (to take off the peel or shell) bare, féke (S.), yin fira (or fira).

shell-fish, an edible, n. Kumba, pl. kumbuna or kumbobi, kumbai.

shelter, n. (protection from light and heat) inuwa, (a place of refuge) gidan chira, wurin chira; a rough grass s. sangaya.

shepherd, n. makiyaye, makyayi, pl. makiyaya or makyaya (S.).

sherd, of pots, etc. n. katanga, tsingaro (S.), sakaina, pl. sakainu.

shield, n. gen. garkuwa, pl. garki, garkinne, kariya, also in a loose sense (lit. battle equipment) kayan dāga; spec. a large round $s$. made of skin kŭtufāni; a large white oblong s. like that of the Zulus, usually carried by high officials kwangara; a small s. kunkeli; a s. made of skin makāri, dangi; a s. made from the skin of the white oryx walwaji, wamwaji, pl. walwazoji.

shin-bone, kuabri, kobri, kwauri (K.), pl. ķwabruka, kwobruka, kobruka.

shine, intr. v. $b a$ (or bada) haske, haskaka; the lightning shines brighter than the sun walkiya ta fi rana haske; the sun is shining ana rana. shining, adj. mai-haske. shirking, n. bahilchi. shirk work, v. huji, see idle.

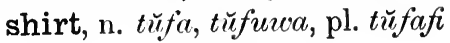


or $t \breve{\text { fof }} f i$ worn under thegown; a shirt with narrow sleeves aganiya, riga, pl. riguna, which sometimes =a large s. ; a small s. $y a$-ch $\breve{k} i$; an inside, pleated s. kwakwata; a s. without arms binjima, bijima; a s. like a tobe but smaller with short sleeves tăgo (S.), pl. tagogi, taguwa (K.), pl.taguwoyi; a s. worn by women shaya; a quilted s. of mail worn by horse soldiers lifidi, lifdi.

shiver, (to tremble, shudder) firgita, firgiche, raura.

shivering, n. makarkata.

shoe, n. takalmi, pl. takalma, wufi*, wupi*; he took off the s. ya fitas da takalmi; a s. strap ma-ballin takalmi; spec. small s. worn inside boots sufadu, pl. sufadai; two odd shoes gamin bauta.

shoot, v. 1. tr. (to hit with a shot, etc.) halbi, harbi; e.g. he was shot aka halbe shi $d a$ bindiga (if with an arrow $d a$ kibiya); cf. the leopard is hard to s. damisa da unyan halbewa; to s. towards the speaker halbo, past particip. shot halbebe.

2. intr. (to discharge a gun) halbi bindiga or buga bindiga.
3. of plants to $\mathrm{s}$. or $\mathrm{s}$. forth yin tofo, sumbula.

shooting, n. (the killing of game) farauta; to go s. yin farauta.

shooting star, n. mashin tamraru.

shoots, of plants yabainya. shopkeeper, sambani, see trader.

shore, $g \bar{a} b a, g \bar{a} c h i$, see bank. short, adj. 1. (of length) găjēre, fem. găjēera and găjēriya, pl. găjēru, also karami (lit. small), cf. guntu; s. sighted garara; to give s. measure bante, tsakare.

2. (of time) kadan, e.g. a s. while jima kadan.

short of, fall, intr. v. kāsa, găza, e.g. thy days are numbered, thou canst not pass them nor come s. of them kwanukanka madudai ne ba ka wuche su ba ka kāsa su.

shortness, n. gajarta, gajerta, hilafa*.

shot, n. (ball, bullet) harsashe, yahaya*.

shoulder, n. kafada, pl. kafadu, kafadodi, kanfăle (S.), karfata, karpata (S.); the two last are especially applied to the shoulders of animals, the part from the 
s. to the elbow damtse, pl. damutsa or damatsu.

shout, n. ifu, wu, guda; see cry. shout, intr. v. yin ifu.

shouting, sowa, sowwa; there was s. ana soyw; much s. sowa sowa.

shove, tr. v., see push.

show, n. (ornamental display) ado.

show, tr. v. (to point out an object, also to inform, explain) gwada, gŏda, nūna, nuni, e.g. he showed me it.

showing, verbal $\mathbf{n}$. in both senses of prec. nunawa.

shrew-mouse, with bad odour jaḅa.

shrike, n. bambami; helmet s. kare-dangi.

shrink, intr. v. (from cold, etc.) firgita; (to shrivel up) takura; to s. from toge ma; they shrank from him sun kare da shi.

shrinking, tsika.

shrivel, intr. v. yin yaushi, kandare; it shrivels up ya yi yaushi.

shrivelling, n. yaushi.

shroud, n. likkafani.

shrub, n., see kaikaya, yadia, biyarana, fidali, etc.; a shrub forming hedges (Jatropha curcas) bi-ni-da-zugu, chi-ni$d a-z u g u$. shudder, intr. v. raura.

shuddering, tsika.

shun, tr. v., see avoid.

shut, tr. v. mufe, rufi or rife, $s \bar{a} d a$, e.g. let not the door be s. kada a rufe kofa; to s. a box, door, etc. yane; to s. up sada, turbude.

shuttle, n. masaka, koshiya; the sliding wooden cylinder which works longitudinally in the s. kwarkwaro.

shy, v., of a horse baude.

sick, adj. da chiwo, marili*; one who is s. mai-chiwo, pl. masu-chiwo, maras-lafiya, majinachi, majinyachi, majiyachi.

sick, be, v. 1. (to be in bad health) jin (or yin) chiwo, also $d a$ chiwo with forms in $n a$, e.g. he is s. shina da chiwo.

2. (to feel nausea) jin kumallo.

sickle, a small semicircular s.,

n. lauje, laushe (Zanf.), magirbi.

sickness, n. chiwo, chiwuta, chivwurwuta, jinya, jinya-jin$y a$; the following words designate special forms: (a cold) mäjina; (a fainting tit) falfrada; (pestilence, plague) alloba, bala'i; (vomiting) amai. side, n. 1. gen. waje, pl. wajeje; 
one on this $\mathrm{s}$. and one on the other s. laya ga wajen ran daya ga wajer chan; from this s. (of a room, glen, etc.) even to that s. dăga sassan nun har ga sassan chan; the right s. wajen dama, duma; the left s. wajen (hauni or) hagum, hagum, hagun; s. of a body (also=edge) kauye; the s. or edge of a stream kauyen ruwa.

2. s. of the body (esp. between the bottom of the ribs and the thigh-bone) kwibi; s. (rib) of an animal awaza, pl. awazzai; on one s. a kauye.

sieve, n. rariya, rairaya, leleya*; a vessel with holes used as a coarse s. $t u$ kunya, matachiya, mararaki, marari*; a s. used for separating gold from sand, etc. matankadi.

sift, to tache, tankade or yin tankade, bakache.

sigh, n. sheda, pl. shedodi.

sigh, intr. v. yin sheda, sinihi*, sinishi*.

sighing, n. ajiyar zuchiya. sight, n. 1. (the faculty of vision) no precise equivalent, turn, e.g. he lost the s. of his eye idonsa ya bache.
2. (the act of seeing, also view) ido, gani thus, in the s. of all men idon duniya; the s. of her will console them ganinta zai ma su hankuri; the s. of them made everybody laugh ganinsu ya sa kowanne dariya; $\operatorname{dim}$ (or dimness of) s. bambarokai; one who has defective s. garara.

sign, n. gen. shaida, pl. shaidodi, which also $=\mathrm{s}$. or mark made by one who cannot write his name; (important or wonderful token, intimation) alama often pronounced halama, pl. alamomi; aya, pl. ayoyi, nūni; a s. adduced or appealed to as a reason or authority dalili.

signet, n. mataushin watika; s. ring zoben shaida.

silence, n. shiriyu, shiru, shiyu, shuru or shu, kurum, kawai, kurumta, kurumchi, zugum (S.); in s. shiriyu, kurum, e.g. leave them in s. $a$ bar su kurum ; to keep s. yin kauai ; he kept s. ya ja bakinsa. silence, to kawaita. silent, adj. kawai or kauwai, jurum.

silent, to be, v. sliriyu, kurum and kawai with $y^{i}$ or 
the forms in $r a$, e.g. be silent! ka yi shiru, kame bakinka; we were s. mun yi kurum; he is s. shina kurum or shina yin kawai.

silently, adv. shiru.

silk, alharini, sirki*, adalashi;

a cord or chain of s. siliya, pl. siliyu and siliyoyi.

silk cotton tree, n. rimi, rini; red-flowered s. c. $t$. gurjiya; the seed of the s. c. t. guriya (S.), anguriya (K.).

silken, adj. na alharini.

silkworm, a species of, $n$. tsamiya.

silly, adj., see fool, foolish.

silver, n. ăzurfa.

silver, adj. na-azurfa, fem. taazurfa.

similar, adj., see like.

similar, to be, v. daidaiche, see under like.

similitude, n. misali; to speak by a s. yin misali.

sin, n. zunufi, zunubi, laifi, pl. laifufuka, kuskuri* ; to commit s., see seq.

sin, intr. v. yin zunubi (or zunufi), yin laifi.

ince, 1. prep. (after, from the time of) tun, e.g. s. your birth tun haifuwarka; s. the commencement of the war tun farawar yaki.

R. H. D.
2. conj. of time (after that, from the time that) $t u n d a$, e.g. s. we learnt that he was an infidel tun da mun sani shi kafiri ne.

3. adv., long s. tun dade, tun dadewa, tuntuni, tuni; how long s.? tun yaushe ? e.g. how long s. did you learn Hausa? tun yaushe ka koyo Hausa?

4. conj. (because) don, zama, e.g. they cannot move since they are lifeless $b a s u$ iya yin motsi ba don ba su da rai.

sincere, adj., see honest.

sing, v. yin waka.

singe, to babbake.

singer, a mounted bambade, pl. bambadawa.

single, adj. barābara; a s. one of a pair, of which one has been lost kangarwa; see alone, one.

singly, adv., e.g. question them

s. (one by one) ka tambaya su daya daya, see also alone. singular, adj. mufuradi, see plural.

sink, n. (a place of filth, also fig.) salga, pl. salgagi. sink, v. 1. intr. (to go under water) nutsa (K.), nuta (S.), nutse, nitso, ninkāaya, e.g. the boat is sinking jirigi 
shina nutsa; to s., i.e. to fall, e.g. of a man wounded or of the sun descending fadi.

2. (to subside) kă $f e$.

3. tr. (to immerse) nuche, nutse; spec. to s. a well gina rijiya.

sinless, adj. maras-laifi.

sinner, n. mai-zunubi.

sip, n. guwa; to take one s. sha daya.

sip, v. kurba.

sipping, n. kurḅi.

sister, n. shikikiya, zumniya (S. and Daura), (usually = younger s.) k̦anuwa; elder s. $y a$.

sit, intr. v. (also to s. down) zamna or zauna; to s. on the ground with legs crossed and elbows on knees gishinkida, kishinkida, gijirta ; to s. with outspread legs tagangana; to s. at ease mimike; to make to s. down zamshe; a sitting place mazauni, $m \alpha$ zamni.

site, n. wuri, pl. wurare; to mark out a s. sha wuri.

six, card. num. shidda; s. times, adv. sau shidda; by sixes or s. each shidda shidda. sixth, adj. na-shidda, fem. tashidda ; one-s. part sudusi*. sixtieth, ord. num. na-sittin, fem. ta-sittin. sixty, card. num. sittin; also gomiya shidda.

size, n. girma employed thus: its fruit is large in s. diyata suna da girma; the s. of the jerboa exceeds that of the mouse kurege ya fi bera gir$m a$; to become (or grow) large in s. yin girma.

skewer, tsinken nama; to fix on a s. soke a tsinke, tsīre*, done.

skilful, adj. (in an art, etc.) goni, gwani, gwanaye, maigwani; (in artifice) maiwayo, pl. masu-wayo, (esp. in war) gardaye.

skilfully, adv. gwani, da gwani, da wayo, da dubara.

skill, n. (in an art or profession) gwani, gwaninta; (in artifice) wayo ; (in contrivance, resource) $d a b \bar{a} r a$ or $d u b \bar{a} r a$; (with implication of opportunity and readiness) tsarafi*.

skim, tr. v. (milk) yāde, kwalfe, kolfe.

skimming, of milk kwalfa, kolfa.

skin, n. gen. fäta, pl. fätuna, pāta, fiska ; (hide) kilāgo, pl. kilagai ; kilabo, agalemi, langabu* ; s. after tanning kir$g i$; cast s. of serpent swaba or saba, zana; he casts his 
s. ya yi swaba; a s. bag or bottle salka, pl. salkuna; a s. used for drawing water from well guga; a covering of skins tunku; a s. wrapper walki.

skin, tr. v. kware, kwari, feda, fede; see also flay.

skink, banded s. (Scinopus fasciatus) damatsiri, tamatsiri (S.) ; red-bellied s. (Mabuia Perrotteti) kulba.

skip, v. (to spring along or over lightly) bira; (to pass over without reading passages in a book) chingara, tsălache. ;kipping, tsalle.

kull, n. kwalluwa, kwakwa luwa, kollo, kwanya, ḳwanyan kai, kashin kai (lit. bone of the head).

kunk, a kind of tunku, see under cat.

ky, n. săma, pl. samaniya or sammai, duniya, gari*.

lacken, v. 1. see loosen.

2. tr. v. (to relax, mitigate) ragi or rage; intr. (to be relaxed, mitigated) ragu, e.g. the heat of the fire slackened zafin wuta ya ragu.

ackness, sainyin jiki.

ander, chimbaya, tsurutu (S.), hardi.

anderer, maradi.

ap, v. kalle. slash, tr. v. (to cut by striking, i.e. not by drawing the edge along, which is yanka) sare. slaughter, tr. v. yanka or yanke, karkăshe, kakkăshe ; to s. animals yin fauta.

slaughter-house, n. wurin fawa, mahauta.

slaughtering, n. fawa.

slave, n. bawa, fem. baiwa, bauya, boya (S.) or bawuya*, pl. bayi or bai; spec. chief s. of a king kachalla, yari; a female s. baiwa (as above), kuyarga or kwiyanga, pl. kuyangai, kuyangi; yan tu$r \bar{a} k a$, (also concubine) sadaka, kwarakwara or kwarkwara, bawan gida; the son of a s. but free bachucheni, dimajo; a s. the offspring of a negro father and Tuarek mother buzu; as. who begs mauro; a s. about 14 years old magudanchi, mugudanchi, pl. magudantai; a strong s. kato, fem. Katuwa; a runaway s. gujajje*; a s. holder mai-bawa; a s. raiding expedition samame, shări; v. to free a s. yanchi; a s. raider mahări.

slavery, n. bauchi, bauta, bawanchi; liberation from s. diyauchi or diyanchi; redemption from s. fansa 
usually pronounced pansa; to redeem from s. yin fansa, bada (or ba) diyauchi, e.g. he freed them from s. ya bada su diyauchi.

slay, tr. v., see kill.

sleep, n. barchi, kwana, kwanchiya; the last s. (death) makarin barchi.

sleep, intr. v. barchi with yi or forms in na, also kwana or kwanche; the former refer rather to the physical condition, the latter convey also the idea of reposing, lying down to s., e.g. we did not hear the howling of the dogs, we were sleeping $b a m u ~ j i$ kukan karnuka muna barchi; we slept at that place mun kwana a urin nan; sleeping kwantawa, kwanchiya; cf. my foot has gone to $\mathrm{s}$. mijiriya ta kama lkafata.

sleepiness, n. gyangyadi; to be overcome by s. yin gyangyada.

sleeping-place, n. makwanche; spec. s.-p. (e.g. in a tree) affording protection from wild beasts saura*.

sleeping sickness, bamota.

sleeve, n. hănnu or hănnun riga; a sleeve-knife the blade of which is worn along or up the s. wukar hănnu. sleight of hand, dabo.

slender, lange lange, see lean slice, a gunduwa.

slide, intr. v., see slip.

slight, adj., see thin.

slight, tr. v. rēna, raina.

slim, shallali.

sling, v., to s. anything oves the shoulder săba .

sling, n. bindo, elawa, maja jaiwa, majejawa, majaujaua majujawa; sword s. hamīla a s. for carrying a child or the back gumya.

slinging, ragaya, rataya. slip, n. (loss of foothold b? sliding) samtsi, santsi, sand (S.) ; to make a s. yiu sam tsi, yin talalabiya, e.g. h made a s. ya yi samtsi.

slip, intr. v. 1. (to lose foot hold by sliding) samtse, yi samtsi, yin talalabiya, gwat chi, tuzga, tuzge, rabkana rafkama; the last also = to $s$ into, e.g. he slipped into th well ya gwabche chikin rijiya to s. as in soft mud kafiya.

2. (to escape hold) kubch sumbule; of things, e.g. th sword slipped from my gi'as takobi ya kubche daga har nuna; of persons (to leav or get away easily fror companions, etc.) zūlke, rabu to try to s. out (used of a 
animal in a trap) kŭbchekübche; of a knot to s. sumbule.

slipperiness, n. samtsi, santsi, sandi (S.), samche, sulḅi, talalabiya.

slippery, adj. dasamtsi, see slip. slipping down or out, participial n. sumbulewa. slit, n., a s. in a seam burāka ; a s. in a stick gebe*. slit, tr. v. keta. slough, n. (cast skin of serpent) swaba or saba; to cast a s. yin swaba.

slow, adj. (one who goes slowly or deliberately) mai-nauwa. slowcoach, madudu (S.), see idle.

slowly, adv. sannu-sannu; very s. sannu-sannu.

slumber, n. and v., see sleep, sleepiness.

slush, tabo, chaḅi, potopoto. sly, adj. da wayo, mai-wayo, pl. masu-wayo; see skilful. imall, adj. Karami, fem. karama, ķaramiya, pl. k̦aramu, ķankane, fem. Lankanuwa, pl. kankana, kanana; smallest auta* ; anything s., n. kima, abuhika,kusugu*; s. quantity of karanchi; s. money (shells) yaskan kurdi (S.).

mall-pox, n. ăgana, ado, zanzana, karambo, yar-rani. smart, a s. fellow dăje, fem. dăjiya, pl. dazoji.

smash, tr. v. (to break to pieces with violence) farfasha, palpashe, ribde, rifde, rubde, rugunguza*, murtsuke. smashed, particip. pass. murjaje, fem. murjajiya, pl. murjaju; murtsukakke, pl.murtsukakku.

smear, tr. v. (e.g. with oil) shāfa, shāfe, yafa*.

smell, n. (odour), an agreeable s. ķamshi; a bad s. doyi, dwai, wari, wardi*; s. of damp fumfuna; an evil s. as of putrefying animal bodies ķarni, ķazni, ḳauri.

smell, tr. v. 1. (to perceive by the sense) $j i$, sunsuna, e.g. I s. the scent of lions $n a$ ji warin zakoki.

2. (to s. at with the intent to enjoy or test) shaka (S.) or sheka (K.) ; to emit a bad

s. yin doyi.

smelt, tr. v. narke.

smile, intr. v. yin murmushi, yin mulmushi.

smite, tr. v., see strike, kill. smith, n., see blacksmith. smithy, măkèra.

smoke, n. hayaki; spec. s. of a conflagration turnuka. smoke, v. 1. (to emit s.) yin hayaki. 
2. (to s. tobacco) shan taba. smooth, adj. $d a$ (samtsi or) santsi, nani.

smooth, tr. v. (of wood, by paring, shaving) sassaka, sabche, sabta, sanche; (by daubing, plastering, etc.) yāạa; to rub s. darje.

smoothed, particip. adj. (by plastering, etc.) yababbe, fem. yabaḅ̣a, pl. yabaḅ̣u.

smoothly, adv. sansamtsa*, sarr*.

smoothness, n. samtsi, santsi, samche.

snail, n. katantanwa, alkoto* snail shell, alkoto (S.).

snake, n. machiji, fem. machijiya, pl. machizzai, igiyar kasa, sago (S.) ; names of different species many of which await identification are: a small s. with a tail which resembles a second head and a double mouth b̌da; a s. which spits like a cat dan mussa; a green s. (Philothamnus semivariegatus) damatsiri, danyen chi . yawa; a black s. masasau; a black cobra from 14 inches to $6 \mathrm{ft}$. in length without spectacles kumurchi, kwamarchi; another species of cobra gamsheka, gamshika, or tamatsiri (in S. this = a skink) ; a black s. about 18 inches long dan mayurji; a puff adder kasa; a long, slender, light-coloured s. kwakiya; a python mesa, muluwa* ; a short black and white viper gajera, kububuwa*; a harmless s. shanono; a yellow viper with flat head injihau, tsada-raki; a poisonous s. sanadi; a brown harmless s. which comes out at daylight tafi ga rana; a large spotted s. tandara; a large s. uwayara; a plant used as antidote to s. bite filasko; a s. charmer gardi, pl. gardawa; turde, pl. turdawa or turdodi; a s. skin swaba or saba, zana*, a water s. ani.

snare, n. hako, pl. hakoki, tarko; to lay a s. yin hako; a bird s. asuta, asibta. snatch, tr. v. kcwache, karḅa, karbi, amshi, fisge or fusge; spec. to s. goods wasashe; to

s. with violence rupta, rupto. snatcher, n. mai-kwachewa. snatching, wasoso, wasaso.

sneeze, intr. v. atisha; sneezing atishawa, furji.

sniff, v. sheḳa, shaka ; to s. up (for the purposes of smelling) id.

snore, intr. v. minshari, hansari, nāsari, hansāri, guarti. 
snort, to sheka hiska. snow, talji* (Ar.).

snuff, n. (powdered tobacco) garin tāba, taban hanchi; taking s. shekawa.

snuff, v., see sniff.

snuff-box, n. batta, pl. battochi. so, adv. (thus) hăka, hăkanan,

e.g. or is it not so? ko ba hăka ba? so it is shi ke nan; kăza, or kăza da kăza is often used in a less demonstrative sense and when something is referred to not named = so and so, e.g. he did so and so ya yi abu kăza; wāne is similarly used of persons, e.g. where is so and so ? ina wāne ; about so much kwatanchin kaza ; so, expressing doubt or some surprise, so! to; so it is ana nan; so that, see under that; so then (therefore), see therefore.

soap, n. sabuni (S.), sabulu (K.), toka ; spec. a superior kind of s. used for washing the face sabunin sălo.

socket, n. kwarmi, pl. kwarmu, gwarmi; s. of the eye gurbin ido; prov. the s. of the eye is not the eye itself gurbin ido ba ido ne ba.

sodomy, ludu, lutsu. soever, affix to words to em- phasise the notion of contingency $k o$ (used as a prefix), e.g. where? ina; wheresoever ko ina; who? which? what? wa, wanne; whosoever, whichsoever, whatsoever kowa, kowanne, e.g. whomsoever you find seize him kowanne .ka samu ka kama shi.

soft, adj. (e.g. of mud, dough, etc., also of cloth) da tafshi, da tabshi, da taushi, da laushi*, labu-labu ; to be or become s. yin tapshi, yin kabushi; of ripe fruit yin tabo (or tambo), e.g. the date is s. dabino ya yi tabo.

soften, tr. v. yin tafshi, $z a b k i$.

softly, lako-lako, săko-săko. softness, kabushi, tabo, tapshi, tafshi, tabshi, taushi, laushi*. soil, n. 1. (ground, land) ḳăsa, pl. kă̌sashe, ķăsaisai; very hard s. tsandauri.

2. see dirt.

soil, tr. v. yin dauda.

sojourn, n. (temporary stay) zama, e.g. how have you been faring during your $\mathrm{s}$. in this town? ina zaman gari?

sojourn, intr. v. (to make a stay) zamna, zauna, e.g. we sojourned there twelve days mun zamna nan kuana goma 
sha biyu, shida or shide (lit. to alight at a place).

sojourner, mai-zamna, pl. masu-zamna.

Sokoto, the town of Sakwato or Sakkwato.

solder, a sort of, (sal-ammonia) sinādari (S.), shinādari (K.), sunādari.

soldier, n. măyaḳi, pl. măyaḳa, dan yaki, pl. yayan (or yan) yaki; askar, pl. askarawa; spec. a s. of a king's bodyguard dogavi, dakāre, dakāra, pl. dakāru ; a foot s. dan la kasa; foot-soldiers coll. kirma, sa'ati* ; see guriguri*.

sole, n. (of the foot) sau, sawu, sauwaiwai, pl. sauwuna, mataki, pl. matakai, tăfin ł̣ăfa.

sole, adj. makadaichi, mukadaichi, s. in its idiomatic use, however, is best expressed by means of sai, e.g. his s. request was this $b a y a$ roko ba sai wannan; our s. food is guinea-corn abinchi namu sai dawa.

solely, adv., see alone.

solid, adj. (sound, trustworthy) ingatachi.

solitary, gwabro*.

some, 1. (used adjectivally and pronominally) wani (often pronounced woni), fem. wata, pl. wadansu, wasu, yasu (S.), wansu; wait, I have something to say bari ina da wani.

2. wani is also used to express the correlatives $\mathrm{s}$. one...another, pl. s....others, also s....s., e.g. s. one said yes, another said no wani ya che $i$ wani ya che a'a.

somersault, the act of turning zuragadauniya, juyen$m \bar{a} s a$ (see under $m \bar{a} s a$ ). sometime, adv. wani yayi. son, n. $d a$, connective dan, pl. yaya, ya, connective yayan and yan, e.g. first-born s. $d a$ nafari; the s. of Amina dan Amina (i.e. Mohammed); used as an expression of regard, e.g. my s. dana; s. of my mother (i.e. friend) dan uwana; also used (as at times in English) to exprass contempt or aversion, e.g. s. of the ignorant (heathen) dan jahili (stronger than jahili alone); s. of the wicked dan mazugu.

song, n. waka, pl. wakoki, wakewake, sara, wasa; v., to sing a s. waka with $y i$ or the forms in $n a$, e.g. I sang them a s. na yi ma su waka; to compose a s. id. ; a religious s. tsāri; foolish songs wakewaken banza.

sonship, n. diyauchi, diyanchi. 
soon, adv. (after a little while) jima kadan, e.g. I shall s. return to you jima kadan ni komo gare ku, cf. also while ; (in a short time, with quickness) maza and frequently maza maza, e.g. I will s. catch him zan kama shi maza maza. soot, finfin(S.), finfini(K.), kunkunniya, kunkumniya (S.). soothsayer, n. boka, pl. bokaye; to act as a s. yin dubi. soothsaying, n. arwa, duba. sorcerer, n. maye, mayi, fem. mayiya, mayya, pl. mayu. sorcery, n. maita, dabu, dabo, kwarche (S.), sihiri, kandu, akokari, tsubu.

sordid, adj., see filthy, base. sore, n. kushe kushe, miki, pl. miyaku, see ulcer, boil; s. on a horse's back getsi. sore, adj., see painful. sores, pl. balli balli. sorrel, red s. yakuwa. sorrow, n. bakin chǐki, mayāta, see affliction, grief. sorrowful, to be, intr. sinihi. sorry, (distressed, pained) $d a$ wahala; to be s. haiya; I am very s. ya bata ma ni zuchiya or zuchiyata ta bache, see grieved; to be or feel s. for, see compassion.

sort, n. iri, pl. irare, launi; see species. sort, tr. v. (to divide, distribute into classes) raba; (to s. out) see choose.

sorted, pass. part. rababbe, fem. rababba, pl. rababbu.

soul, n. rai, pl. rayu, kuruwa, both are used of the disembodied as well as the embodied s.; (the seat of the mental feelings and qualities) rai, e.g. of haughty

s. da girman rai; patient of s. da sanyin rai.

sound, n. (e.g. of bees, a bell, gun, trumpet) amo; a confused s. d̆umi.

sound, adj. (trustworthy) inga. tachi; s. (in health) da lafiya. sound, intr. v. yin ămo.

soup, n. romuwa (S.), rome (K.), miya, ruwan nama; spec. $\mathrm{s}$. in which fura has been made farau farau, faro faro, ruwan fura ; red sorrel, a common ingredient in $\mathrm{s}$. yakuwa; a herb the leaves of which are used in making s. sure.

sour, adj. da tsami; to be s. yamama, yanyama; the soup has gone s. miya ta yi yami. source, n. (spring of water) idon ruwa; s. of a river gindi; (origin, beginning mafari ; (of words, the primitive meaning or derivation) 
gutsu, e.g. what is its s.? minene gutsunsa? (first cause) sababi, e.g. the s. of the illness was this sababin chiwuta ke nan.

sourness, tsami, tsamiya, yami. souse, tr. v. (to immerse) tsoma, nuche (S.), nutsa.

south, n. kŭdu, kŭdus, gǔsum, tsăkar rana; adv. id., e.g. he went s. ya tafi kŭdu. southward, adj. (towards the

s.) gŭsumchi, kudanchi. sovereign, n., see king. sovereignty, n., see kingdom. sow, n. (female of wild swine) gadoniya, gyadainya (S.) ; (of domestic) gursuna mache. sow, tr. v. shipka, shibka, shuka; a hole in which to s. seed sāra.

sower, n. mai-shipka, mashipki.

sowing-time, n. manomi, also fig., e.g. this life is a s.-t. for the future life, ita $d u$ niya nana che manomi a lahira.

space, n. (open, free room) sarari, fage; unoccupied sp. (e.g. on the ground, etc.) fili, pl. filaye, kanwuri, farfajiya, sarari, e.g. there is no $s$. here for my load babu fili a wurin nan ga kayana; in a less precise sense wuri (place) may be used.

spacious, adj. mai-sarari, maiyalwa.

span, n. (a measure of length, i.e. the space between ends of thumb and first finger extended) tăki, dani. sparks, tsartsatsi.

sparrow, n., the African s. magwara.

speak, v. făda and fădi, tăne, zanta (K.), e.g. I s. the truth to you ina făda ma ku gaskiya; (in the sense also of conversation) yin zanche; to s. with zantad $d a$; to s. a language yin magana, e.g. we are able to s. Hausa $m u$ na iya yin maganar Hausa; to s. evil of $b \bar{a} c h i$; to s. evil of behind one's back chimbaya; to s. proudly yin raha; to s. secretly or to $\mathrm{s}$. in whispers rada; speaking $f a$. dalle, see say.

spear, n. mäshi, pl. masusuka, or masu; spec. a long s. not thrown kasausaua; a small s. for throwing hankaltilo; a small s. tied to wrist and which after being thrown is pulled back hargi, pl. harugga; a s. or dart for catching fish hăgu, margi; v. to cast a s. as a sign of 
declaration of war yasda (or yada) mashi; s. throwing năshi, pl. nashe-nashe.

spear, tr. v. soka, soke or soki, halbe, halbior harbi, chăke, e.g. he speared a fish ya soka kifi. spearman, n. mahalbi, pl. mahalba and masu-halbi. species, n. iri, pl. irare, launi, e.g. they had collected stones of various s. suka tattara duwatsu na iri dabam dabam. speckled, adj. (of birds, etc) wake-wake, see spotted. specks, coll. (spots or dots, e.g. on plumage of birds) zane; spec. $\mathrm{s}$. in eyes of blind tsauriya; see spot. spectacles, n. (the optical instrument) minzari*. spectre, n. fatalwa.

speech, n. 1. gen. magana, which can be used in all the following senses.

2. (the uttering of words) fadi, pl. fade-fade, fada, ja$w \bar{a} b i$, e.g. he would hear my s. shi kan ji fadata; until s. be heard (i.e. is ended) har magana a ji ta; confused, noisy s. dumi.

3. (uttered words and so talk, discourse) zanche, kalami*, aljama, aljima, jawabi.

4. (native language) hausa*, pl. harata, halshe, harshe, pl. halshina, halussa (S.), e.g. in the s. of the Fulahs da halshen Fillani; he understands the Hausa s. ya ji maganar Hausa.

speechless, adj., see dumb, silent.

speed, n., see haste.

speedily, adv., see quickly, soon.

spell, n. (charm) magani, pl.

maganguna and magunguna. spend, tr. v. kăshe, kǔsa, kăsa, bātas, (with the idea of waste more or less implied), e.g. he spent much nioney ya kăshe kurdi dayawa; aikata da; to s. time samu; he spent one month ya samu wata guila. spew, v. tofi, kurkure. sphere, azurumi*. spice, hot, n. yaji, chefane (S.) ; cf. kula* ; spices coll. jauwi*; see pepper.

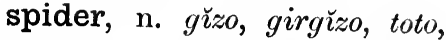
tautau, rozo; female s. koki ; spider's web sumya, shaushaudo (S.), tautauchi, yane, the spider's wife (in stories) koki.

spiderwort, bulasa.

spike, n., an iron s. tsinke, chinke (S.), pl. tsinkai; also = a little s. of straw; s. for making holes in skin, etc. tsiko, pl. tsikuna. 
spill, v. 1. tr. (to let run over) tuddas.

2. intr. tuda or tude.

spilling, barbaduwa.

spin, v. 1. tr. (to twist into thread) zare, zari, yin kadi; to s. yarn sabi*.

2. intr. (to revolve) kewaye, kewayi, e.g. the top spins $m a-$ kodi ya kewaye.

spinach, native s. alayafu, alayapo.

spindle, n. mazari, kadamin abduga; a sort of $\mathrm{s}$. made of skin mataki; a mud ball on a kind of s. used in winding thread gululu.

spine, (backbone) tsatso.

spinning, n. kadi, wădira* uodira*.

spinning round, anything, $n$. makodi, e.g. ball, top, etc.

spinster, n. gwabruwa; an old

s. tuzuruwa.

spirit, n. ruhu*, (soul of man generally, also as the seat of feelings, etc.) see soul, (an immaterial being, a s.) id.; the evil s. eblis, shaitan, shetan, shaitan, shaidane, iblis ; an evil s. aljani, fem. aljana, pl. aljannu, janziri*, janzari*, kankama, kaura; evil spirits coll. jinnu, also the pl. rayuka; (a ghost) see spectre; (mind) zuchiya, e.g. tranquillity or happiness of s. dadin zuchiya; spec. terms connected with popular superstitions are: a s. described as having hair hanging down its face and often appearing in trees dodo, pl. dodani; a s. that renders a man mad or delirious bori; evil s. said to kill mother and child at birth uwayara; an evil s. supposed to injure tamarind and other trees doguwa; an evil s. in form of snake gajimare; persons and esp. women possessed by an evil s. masu-bori or masuboli.

spiritless, adj. $d a$ karamar zuchiya.

spit, n. tsinke.

spit, v. 1. tofa, tofi, fésa, pēsa, furji, furza, kaki; to s. out tofi, tofar da, miyau, yau, tsalga (S.), tsalte, tsarta; to s. out water from the mouth tsartso, see spurt.

2. see pierce.

spite, n. chegi, for s. don chegi. spitting, participial n. fèsawa, feshi, tofi, e.g. s. accompanied by s. of blood fēsawan jini. spittle, n. dalele, salabi, miyau, yau (K.).

splashing, e.g. of water bundum-bundum, funjum, tsin- 
dum, pinjum, jirwaye* ; an exclamation descriptive of $\mathrm{s}$. tsut, tsulut.

spleen, n. (the bodily organ) sefa, saifa, pl. saifoji ; (disease of the s., splenitis) chiwon saifa; trop. (vexation) haushi, e.g. his s. was roused at this ya ji haushin wannan. splendid, adj. (of dress, ornaments, etc.) na ado, fem. ta ado. splendour, n. (of dress, etc.) ădo.

splenitis, n., see spleen.

splinter, n. (e.g. in the skin) sartse.

split, n. $t s \bar{a} g a, t s \bar{a} g i$.

split, tr. v. tsāga, kēta, firda, farde, datse (S.), făsa, the last also used of cold, faskara. splitting, 1. participial n. $k \bar{e}-$ tuwa, fasawa, faskari.

2. adj. mai-fasawa.

spoil, 1. tr. v. (to waste, injure) bāta, bāchi, bāche.

2. intr. (to be spoiled, wasted, etc.) ba ache ; of fruits, etc. (to go bad, rot) riba or ruba.

3. n. and tr. v., see plunder.

spoiled, pass. part. bātache, fem. bātachiya, pl. bāatattu, rubaḅbe, fem. rubaḅbiya, pl. rubabbu; to be s., see spoil 2 . spoils, a half share of $\mathrm{s}$. paid to the leader of an expedition after a raid hamushi. sponge, n., soso (K.), susu (S.), i.e. the fibrous network of the fruit of a species of gourd, the 'loofah' gourd; anything used as a s. abin shafe.

spool, matari.

spoon, n. (made of wood) chokali, ḳoshiya, kwiyafa, kuyafa (S.) ; a s. used for measuring madebi; a large wooden s. moda; spoons made from pumpkin rinds pl. lüddai.

spoor, lawali.

sport, n. (play, diversion) wargi; (mirth, also mirthful contempt) dariya, e.g. we made s. of him mun ba shi dariya; (of the field, as fowling, hunting) farauta. spot, n. tabo, pl. tabuna, tambo (S.), dangole ; a s. or blot, e.g. of ink dole, kyanda, pl. kyandu, zane, pl. zane-zane; (a blemish in an article) aibi, aibu, pl. aibobi, sōfane, pl. sofanai; a s. of grease maski; fig. (moral blemish, fault) aibi, aibu; (a particular locality) wuri, pl. wurare; (speckle) rodi, pl. rode-rode.

spots, having s., adj. wakewake.

spotted, mai-rodi. 
spout, n. mazurari.

sprain, n. targade.

spread, tr. v. (e.g. a cloth, a mat) shimfida ; intr. (to separate, scatter) watse, wache; to s. out, tr. (esp. used of spreading out goods for sale on a mat) shimfida; to s. out (the legs) tantana; to s. out wheat to dry baza; (to expose to view) bayăna or baiyana; intr. to s. out or abroad, increase yado, yadu, malala, nasa.

spring, n., of water, idon ruwa, maromaro, marmaro, marmaru; the mouth of a s. or well bakin rijiya; for other senses see source.

spring, intr. v. 1. see jump.

2. to s. or s. up out of the ground (of seeds, plants) tsǐra, tsĭre, tsirro, chira; (of water) balbadu, barbadu.

sprinkle, to buta, bursuna (K.), fantsama.

sprinkling, n. kurmuwa.

sprout, n. (of guinea-corn, etc.) karmāmi; (of trees) tofo, pl. tofuna; spec. new sprouts after trees, etc. have been cut down kankama; sprouting corn yabanya.

sprout, intr. v. l. (to spring up out of the ground) tšra, tsĭro, tsĭri, see spring.
2. of trees and plants (to put forth buds, leaves, etc.) tofu, yin tofo, yin foge, yin gunda, e.g. the trees s. itatuwa sun tofu; the melon sprouts kabewa tana gunda. sprouting, gauro, gyauro.

spue, v., see spew.

spur, n. Kaimi, pl. ķayame; s. of a cock lăg fa.

spur, i.e. to prick with a s. chăchăka.

spurs, long riding-boot with, n. kufita or kufuta, pl. kufitai, kufutai, kubutai (S.), kuftai (K.).

spurt, to s. out tartso, tudas, fantsama.

spurting, tartsatsi, tudaswa. spy, n. gāta, pl. gataye, majewayi, magewayi, pl. majewaya.

spy, to s. or s. out jewayi, jewaye, leḳa, leḳi, leḳo, yin shigoro.

spying, n. dauraro, dararo, jewaya, shigoro.

square, n., a s. of men kewanya. squash, to (e.g. with the foot) latse, lowatse.

squat, intr. v., to s. down with legs crossed kishinkida, gijirche (S.); to s. on the ground tsugunna.

squatting, n. tsugum; (the body resting upon the inside 
of the thighs with the feet splayed outwards) zaman rakumi; s. with outspread legs tantāna.

squeeze, tr. v. mache, matse, matsa, taushe (S.), tausa (K.), damfare, tsamki, tattara, rumchi, rumtse; to s. a lemon, etc. tatsa, tatse, twatsa, twache. squeezed, pass. particip. taushashe, fem. taushashiya.

squeezing, participial n. taushewa; s. through a narrow place bokoto.

squint, n. idon măge.

squirrel, n. kusum-b̌sa; Afi-ican flying s. beran busa; the spiny ground-squirrel kurēge.

squirt, to tsurara.

stable, n. muri, barga, maiturke; and less precise (a place for horses) shamaki, pl. shamakai, shamakoki.

stable-man, n. dan muri, barga, birga, see also groom. stack, a s. of corn matāra, mataran hatsi.

staff, n. sanda, pl. sanduna; kulki, pl. kulake.

stagger, v. 1. intr. magagi with forms in na, e.g. he was struck by a bullet, he staggered and fell aka halbe shi da bindiga yana magagi ya fadi.
2. (to confuse, perplex) dāme, dāma and pass. to be staggered damu.

staggering, n. (e.g. of a dying man) magagi.

stain, n. (colouring matter), e.g. a red clay used for staining eyelids, etc. koya, kowa ;

a red vegetable $s$. for the teeth kuriya, see dye ; (spot, blemish, fault) aibu, kufa.

stain, v. (to tinge fabrics, etc. with colouring matter), see dye; pass. to be stained (in a wider sense), turn by general terms for 'change' with the appropriate complements, e.g. the field was stained with blood wurin fada ya sauya ja da jini or wurin fada sai jini; the waters were stained all red ruwaye sun sauya ja wur ; to s. the face dambara, dandambara; esp. to s. the face blue dambara.

staining, yanayi.

stairs, pl. n. (steps) mahayi, karangama; see steps.

stake, n. rino, rinu*, shishike (S.); a s. in gambling riko. stalk, n. (of plants) kăra, pl. karare, alkäjiya, tsirgagiya; (of corn, etc.) zangare, zangarniya, pl. zangarnu, karmāmi, firchi; stalks (of 
beans, ground-nuts) harāwa ; stalks of grass used for horses' food tattaka; corn stalks used by tanners karandăfi (S.). stalk, to s. an animal rabe. stall, n. 1. (for cattle) garke, pl. garkuna; s. (or paddock) barga.

2. (a stand in the market) rumbu, rumpa, pl. rumfuna. stallion, angarma, ingarma ; mounting of a mare by a s. nuni.

stammer, intr. v. inina, inna. stammering, n. ininan halshe, kikiniya.

stamp, n. (seal) mazubi, mataushin watika.

stamp, to s. down dăbé, tattaka; stamping down (e.g. a floor) dăbe-dăbe.

stand, on which things are exposed for sale, n., see stall 2. stand, intr. v. tsayi, tsaya or tsai which also=to s. up and to s. still, e.g. s. there till I am ready ka tsayi nan har na yi shiri; to cause to s. still tsaishe; I s. upright na tsaya daidai; to s. by or up for (to aid), see help. standard, n. 1. (of proportion, measure), see measure.

2. (flag of a king) tuta, tuti, pl. tutochi. standing, tsaye. star, n. tamrāro, taurāro (Daura), pl. tamrāru, taurārai, tatsuniya, pl. tatsuniyoyi; spec. the morning s. gamzaki; a shooting s. mashin tamraru.

stare, n. kallo, zuru.

stare, v. also = to s. at (of curiosity) yin kallo; yin zuru, e.g. you keep staring at me ka faye kallona.

starling, dokin buntu; the glossy s. or grakle tsakwaikwaiwa.

start, n. sabko, safko.

start, v. 1. intr. (to move suddenly through fear, etc.) razana or razani; (of a horse) to s. or s. back $z c$ bura; to cause to s. zaburi; (of a restive horse) to s. tuma.

2. intr. (to move off, set out) tashi, sabko, safko, sapko, yin sabko, e.g. he prepared to s. ya sake tashi; tr. (to send off) tada, tayas da, e.g. I started a messenger na tada manzo.

starve, intr. v. (to perish by starvation) mutu da yunwa. state, n. (condition) zama and zamanchi; intr. v. to come into a s. zăma, $\operatorname{zam}$ (S.), zama, e.g. he came into a s. of distress ya zama matsiyachi. 
state, v., see narrate.

statement, e.g. before a judge biyaya.

stay, intr. v. zamna, zauna, sauka; wanzu, which also means to delay; to $s$. at a place (i.e. to rest) yin mugāma; to s. at a place or occupation for a day only yini, e.g. there we s. a day nan mu ke yini laya; I s. at work the whole day ina yini aiki; a s.-at-home (person) kifin rijiya; to s. proceedings tsaida magana; to cause to s. zamnas da, zamshe. iteal, tr. v. sache, yin sata, yin swane (or sane); spec. to $\mathrm{s}$. goods kwache.

tealing, n. (theft) sata, barawonchi, sane, swane, barauchi; s. earnest money chin amana; cattle-s. wăgi*, wŏgi*.

tealth, he went by s. ya yi sanda.

tealthily, sullup.

tealthy, s. walk as of a thief sanda.

team, surachi, tururi.

team-boat, n., a s.-b. is usually designated by Hausas who have seen one by jirigin wuta or jirigin hayaki; a locomotive s.-engine dokin urta. teep, tos. in watertšma, tsoma. teeping, in water tsime, tšmi.

R. H. D. stem, n. (of plants) kara, kare. stepchild, agola, pl. agololi, taliyo.

stepfather, n. uban rana. step-parent, tălafi, taulafi. steps, n. mahayi, tākawa, karangama; spec. s. formed of mud mataki, pl. matakai; s. by which to come down from a place mashidi; s. placed for mounting a horse likkafa* and likkafan doki*. sterile, adj., see barren. steward, n. (manager) wakili; to act as a s. wakilta. stewardship, n. wakilchi. stick, n. sanda, pl. sanduna, kurki, kulki, pl. kulake, kuma; walking s. kandiri, kwagiri; (such as is used by a blind man) jagōra, gucalma; a s. cut from a tree and in this sense usually fem. iche or itache; a thin bending s. tsumanjiya; a heavy s. guduma; a s. carried by porters loko*; a $\mathrm{s}$. used for stirring soup etc. muchiya, maburgi, maburkaki (S.); a crooked s., e.g. one used for pulling down fruit rorami; a s. with a bent handle pauma.

stick, v. 1. tr. (to pierce) soka, soke or soki.

2. intr. to stick fast (e.g. in a narrow passage) yin 
barankam; also s. to or together lazumta, lazumche, kakkafe, like, liki, nana, see adhere, cleave to.

stickiness, yauki, yapki, yabki. stiff, to be, intr. v. gage, gaga, sanķare, sandare, kăge, săge ; of skins etc. kandare (K.), kangare (K.), kangare (S.). still, to be, intr. v. kawaita, pass. impersonal, be still! a kawaita.

still-born, haifuwa bari.

stilt, black-winged s. takabădo, takabarbado (S.).

stilts, kadarko*.

sting, tr. v. halbi, harbi, sāra, tăba, balle, balla.

stinginess, n. kalmashen zuchiya, rowa, tšmi.

sting-ray (Trygon), kunāmar ruwa.

stingy, adj. da rowa, mairowa, bahili*.

stink, n. doyi, dwai, wari; see smell.

stink, intr. v., e.g. they's. suna doyi.

stinking, to become, intr. $v$. zama wari.

stir, v. 1. tr. (for the purpose of mixing) ruda; to s. about in a pot while cooking talga, talgi, tüka.

2. intr. (to move oneself) yin motsi. stirrup, n. likkafa; an iron s. $k e b e^{*}$; leather cords by which the s. hangs kinami; brass stirrups zarnawi.

stock, n. (seed, kind, tribe) iri, pl. irare.

stockade, kăfi, kahi (S.).

stocks, e.g. a $\log$ to which a recaptured slave is fastened turu.

stolen, kwachache; a receiver of s. property dan tugu. stomach, tumbi, pl. tumbuna. stone, n. dutsi, duchi (S.), pl. duwatsu and duwarwatsi*, pa (S.), pl. păni; a flat s. for rolling rice on magurji; a precious s. yakutu*; a white s. zaura*, idon zaura; a s. ball makodi; slinging a s. majaujawa, majajaiwa; a small s. burguje (S.); a stony plain hamād $a^{*}$; a s. in the path kauwa*.

stones, n. in coll. sense, small s. tarki*, tsăkuwa; s. collected together, e.g. round a well marmara; s. used as a support magirkai*. stool, n. kujera.

stoop, intr. v. sunkwiya, sunkuya, tsugunna; one who stoops dukau. stop, full, n. kora. stop, v. 1. tr. (to make or cause to stand still) tsaishe, 
kwăḅe, kwăbaa, kwăḅo, tăre, tăra; s. it with your hand tăre shi da hannu; to s. up a hole like, toshe.

2. intr. (e.g. of one walking, running, etc.) tsayi, tsaya or tsai; (to come to an end) id., e.g. at that point it stopped daga nan ya tsaya; (of a horse etc.) zame.

3. to delay dăde.

4. to s. up duade; stop thief! ku tăre ku tăre; (to stay, stay at, etc.) see stay. tore, n. 1. (a supply laid up) ajiya; a large s. of anything tuli, jibgi.

2. (a place for storing things) vumbu, rufogo, gunsakawa.

tore, tr. v., also to s. up aje ; to s. up goods jibga; to s. up treasure tarkache.

tore-room, n. taska, pl. taskaki, see store 2.

orey, upper, in a house, $\mathrm{n}$. kandaki, pl. kandakun ‘, soro, tsoro.

oring grain, a chamber for, n. rafoniya, pl. rafoni; a large barn for s. g. rufogo, see store 2.

ork, n., black s. kasheri, maijikka; the marabout s. borintumki, babba da jikka; a tall red and white s. tsagagi; the saddle-billed s. or Jabiru, jahirma; rosy s. or African wood-ibis tsagagi; sacred ibis jinjimi; Hadadah ibis rara. storm, n. hădari, pl. hădara ; a whirling dust s. 'guguua, holoko, huluku; a heavy rain s. or rain cloud zirnaniya or zurnaniya.

story, n. kariya*, tatsuniya, pl. tatsuniyoyi (latter also $=\mathrm{a} \mathrm{s}$. told at night, a fireside s.), gātana, riwaya (S.), aljama, aljima; an untrue s. kariya, firc or hira*; the telling of a s. riyaya; a s. (told as an allegory) almara.

stout, adj. 1. (of persons = fat, of things = thick) $d a$ kabri, da kauri.

\section{2. see brave.}

stove, n. murufu, madafi. stow, tr. v. (to lay up) aje. straight, adj. sosai, daidai*, e.g. they followed the s. path sun bi hanya sosai.

strain, tr. v. (to filter) rare, tache; to s. out rare, tarāre, tarāro.

strainer, n. marari, marare. straining, n., a calabash with holes for s. rariya.

strand, e.g. of rope nunki, ninki, rĭbe.

strange, 1. (foreign) bako, fem. 
bakuwa, pl. bakuna, baki and bakokuna.

2. (odd, extraordinary) bako; this notion is also expressed by the n. al'amari (matter) in the pregnant sense of 'a s. matter,' e.g. what a s. thing ! al'amaringa; this s. war wamnan al'amarin yaki. strangeness, n. bakonchi, bakontaka.

stranger, n. bako, fem. bakuua, pl. bakuna, baki and bakgolauna, hadāka, pl. hadāku, ba-ture; to act as a s. yin bakonchi or yin bakontaka; service done to a s. baḳonchi, bakontaka.

strangle, tr. v. shakii, shäkie, makure.

strap, tied to bit, n. kamazuru. stratagem, n. wayo, hila, fila, yaudara, idon-yaki ; to use s. gama with uayo or kai.

straw, n. tsaive; s. hat mala$f a$, malfa, pl. malafuna and malafai, garumfa, garunfa.

stream, n., small running s. malala; a fast flowing $\mathrm{s}$. korama; the hollow of a $\mathrm{s}$. liwazazzabo.

street, n. hanya, pl. lunyoyi, see way.

strength, n. (inherent power or firmness) karfi, karifi, kwarri* ; (power over something else) iko, pl. ikoki; these terms differ as absolute and relative, e.g. s. of mind karifin zuchiya ; he surpassed him in s. ya fi shi karifi; we do this by the s. of a charm muna yin haka da ikon magani, kambi* ; to exceed in s. gāgăra.

strengthen, tr. v. Karfafa. stretch, forth, tr. v. miku, mike; to s. a bow-string tanka; intr. to be stretched forth or out miku; to s. out the hand zurma; to be stretched out (used of a dog' lake (S.) ; stretching one': limbs sleepily on wakin magagin barchi.

stride, chirawa; to s. yin chi rawa, miḳe tsawo.

strife, n. făda, fama; (s. o tongues, contention) haya niya, gardama.

strike, tr. v. māra, see beat and the verbs given uride blow n.; to s. (and so bruise smash)falfasa, bubbuga, ribdt rifile, rubde; to s. a tent nad laima ; to s. with the fist dan kuasa, dankwashe; to s. drum buga, kāda, kwwankuasa striking, tabi; s. repeatedly participial n. marmarauca bйga-bŭga. 
string, n. igiya, pl. igoyi and igiyoyi; siliya, pl. siliyu or siliyoyi ; wadari, pl. wadura; spec. s. for tying up trousers mazargi, zariya; strong white s. made of flax kirtani. strip, n., of cloth kwariya; strips of black leather kuaro; to cut into strips rede.

strip, tr. v. kware, kwari, fige ; to s. (skin of fruits, etc.) bāre, bāra; to s. leaves from a stalk kwolde; to $\mathrm{s}$. off garments tube riguna, debe riguna.

stripe, n. (blow) fig. sanda. stripe, n. (in cloth, blue) saḳi, suaki; stripes (e.g. on a bird, etc.) zane; having stripes, adj. wake-wake; to draw stripes zana, zani.

striped, (cloth) saki-saki. strive, intr. v., see attempt. stroke, n. mari, pl. maremare ; see also blow.

stroke, to, with the hand lriilaya, săha.

strokes, n., see lines. itrong, adj.mai-karifi, pl.masuḳarifi, da ḳurifi, ḳodago, da gazau, da tauri, ishashe, fem. ishashiya, pl. ishashu; very s. kakkarifa; to be s. yin kwāri; he is stronger than I ya buwaye ni; I anı stronger than you na bu- waye ka; spec. s. in war gargami, garkami; very s. (epithet of lion) yadangu; a s. man ḳodago, guarzo, pl. gucaraje; to be s. bunkassa; s. slave kiato, fem. Katurva, pl. katta.

strongly, adv. da karifi. strophanthus, (used for poisoning arrows) kwankwani. strutting, takama; (of a wo. man) made.

stubble, n. kututtura, kututture, kotuttura; the s. of guinea-corn, wheat, etc. tushiyre.

stubborn, adj. mai-kinji, pl. masu-kinji, dataurinzuchiya, da tsayaya.

stubbornness, n. tauri, taurin zuchiya, tsayaya.

study, r. (to endearour diligently) yin anuiya, e.g. s. to follow the true path ku $y i$ anniya ku bi hanyar gaskiya. stumble, intr. v. tuntsure, yin tuntube, yin tangadi; to s. against a stone kăro $d a$ dutsi.

stumbling, n. snnsarifa, sassarifa, shekarakki*, tangadi (K.), tuntube.

stump, n., of tree gutsun itache, gatsa, kori, kwabri, gungume, pl. gumagumai, guntu, kututtura, kotuttura ; a snall 
s. tsatsage; s. of a leg or arm dungu.

stupid, adj. (wanting in sense) maras-hankali.

stutter, intr. v. i’ina.

stuttering, n. i'inar halshe.

sty, n., in the eye hazbiya,

bununuwa.

subdue, tr. v. (to conquer, e.g.

a people) $c h i$.

subject, n. (matter) tada, pl. tadodi, e.g. a s. of enquiry tadat tambaya.

subject to, to be, intr. v. (to

be characteristically prone

to) turn by means of tarka, e.g. he is s. to terror ya tarka razana, see character.

submission, putting earth on the head as a sign of huruwa. submissive, adj.mai-tankwasa. submissiveness, n. tankucasa. submit, intr. v., e.g. I s. myself na tankwasa kaina.

subscription, (e.g. a contribution of food) tarbache.

subside, intr. v. (e.g. of water) kăfe, wuche, fuche; (gen. to abate, lessen) rage, ragi, ragu. substitute for something, $\mathrm{n}$. maimako, maimaki, madadi, madadin*.

suburb, n. unyuке, апуика,

pl. unguwai, ungwanai, ungunnai.

succeed, intr. v. 1. (to be suc- cessful) iyas, iyas da, iyar $d a$, lāarasa, yin zama; impers. it succeeds ya kama, ya yi ; to s. (as heir) $g \bar{a} d a, g \bar{a} j i$ or gāje.

2. to s. (i.e. to take the place of another) maya, mayi; to be succeeded by gada $d a$. success, dache*; (in war), $\mathrm{n}$. năsara and nasarchi; to obtain s. (in war) yin năsara, katari.

successor, mamayi.

such, demonstr. adj. 1. (like that) e.g. we cannot do s. a thing ba mu iya yin abu kaza.

2. (that referred to, the naming of which is avoided by narrator), e.g. ho! (or here !) s. a one ya ka mutum $k a z a$; take this inoney to s. and s. persons ku tafi da kurdin nan ga mutane kaza da kaza. suck, tr. v. tsotsa, tsotse, sha; to s. a lime or lemon sha lemu; (of infants) sha nono; to s. in or up (e.g. as a sponge water), id.

sucked, tsotsatse; a s. lime tsotsatsel lemu.

sucking, tsotso.

suckle, tr. v. (to give suck to) goyo, yin goyo, ba nono.

Sudan, pr. n. Sudan.

sudd, (floating grass) tsamba, damba.

sudden, adj., s. death saukin 
mutuwa; s. action is sometimes expressed by wuf, e.g. he gave a s. jump ya yi wuf; see quick.

suddenly, adv. da sauki, bum, mamaye, mame.

suffer, v. 1. tr. (to endure) jimri; (to allow) bari, bar, e.g. s. me to enter bar ni in shr̆ga, phr. s. me kiyaye ni.

2. intr. (to undergo pain or distress) sha wahala.

suffice, v. isa and ishe.

sufficient, adj. ishashe, fem. ishashiya, pl. ishashu, also expressed by appending the impers. ya isa or ya ishe, e.g. we have s. bread muna da gurasa (ya isa or) ya ishe mu; exclamatory phr. s..! bus, which = say no more !; to be s., see prec.

suffocate, suffocation, v. and n., see choke, choking. sugar, sukur*, takanda*. sugar-cane, n. takanda, răke, arakke (S.), kăran sariki. suicide, kiskansa (S.), kaskansa (K.).

suit, n. (claim at law) kara, q.v.; to make or bring a s. kara and kai kara.

suit, v. gamshe, gama, e.g. it suits me ya yamshe $n i$; this dress does not s. me rigan nan ba ta karbe ni. suitable, adj. daidai. suitor, mai-neman aure. sulk, to dakile. sulphur, fara wuta, kibrit*. sum, n. (aggregate of numbers) kida or kididdiga; (of a statement), see substance. summit, n. kai, koololuwa, tsololuwa, b̌sa; s. of hill kan tudu, tuluwa (K.).

summon, tr. v. kĭra, kiraya or kiraye; to $\mathrm{s}$. to where the speaker is kirawo.

sun, n. fem. rava, ra, pl. ranuka*; the s. rose rana (ta fita or) ta tashi; the s. set rana ta fadi, the $\mathrm{s}$. is about to set rana ta kusa faduwa; heat of the s. gumi.

sunbird, sha kauchi; ruddythroated s. janbarde.

Sunday, n. lahadi, làdi. sunder, tr. v., see divide. sunken eyes, one with, adj. and n. mai-kwarmi*.

sunrise, time of, n. tascuual hantsi; cf. it is s. rana ta fïta chim.

sunset, n. fituru, fadawar (or fieluwar) rana.

sunstroke, n. jiri. superfluity, n. wanji. superior, adj. mafifichi, pl. mrefifite; this is $\mathrm{s}$. to that urenenene mefifichi dăga wanchren; to express "this thing 
or this method is s.' use the impers. yara haka, or guama $h a k \alpha$, lit. it is better so, see also surpass.

superiority, fiyăya, fiyăye. supplicate, tr. v. (to pray earnestly) băra, kīma la afa.

support, n. madogara, makari, tankari; the last also fig., e.g. a king is the s. of the world sariki shi ne tankarin duniya; spec. (pole of house) gimshiki; he called for s. ya buga yaya; see also aid, assistance, help.

support, tr. v. (e.g. as a pole supports a tent) tōkăra, tankare; spec. to s. anything with the hand spread out tallaba; to $\mathrm{s}$. oneself with the palm of the hand dafa.

suppose, v. zăto, zachi, zache, tamaha, kintate.

supposition, vasuwasi.

sure, adj., see trustworthy.

sure, to be or make, v. tabbata, tabbache; I am s. na tabbata.

surely, adv. (certainly) tabbas, ashe, da yaskiya, da graske, gaske, hakika, hakikia ; s. is also idiomatically expressed by the particle sai as well as the v. tabbata, e.g. the people will s. rise mutane sai su tashi; he is s. there ya tabbata nan; you mays. assume that he is an infidel ku tabbata kafiri ne. surety for a debt, n. lamuni; (a person who is s.) mailamuni; to be or become s. lamunta, lamunche; with acc., e.g. we became s. for the merchant muka lamuntr falke.

surfeit, ginsa; to cause s. ginshe.

surging, n., e.g. s. backwards and forwards in battle daukakkeniya.

surpass, tr. v. $f$, yin fifiko, uaye (S.), tsere, dada, e.g. the strength of elephants surpasses that of camels karifin givaye ya fi na rakumma; this surpasses that wannan ya dadi wanchan; to s. anyone at his trade or profession shashe.

surpassing, n. fi, pl. fiye-fiye, fifiko.

surpassing, adj. mafi.

surrender, tr. v. (to give up, resign) sallame.

surround, tr. r. kewaye, kewayi, kewayo.

survivor, the sole $s$, of a family barau. suspect, to tuhuma. suspend, tr. v. rataya, yin rataya. 
suspicion, n. matsina*, tuhuma.

sustain, tr. v., see support.

swagger, to yiu täkama.

swaggering, n rangwada (S.), rangaji (K.), tāḳama, yanga, macle; (used of a woman) alfarma, manti, yatsuna.

swallow, n. tsaitsewa, tsaijewa, tsetsewa, chechewa, chichiya ; the large mosque s. knardodo; the small mosque s. mashirare, masherera.

swallow, tr. v. hade, hadiye; swallowing hadiya; the act of trying to s. kučra.

swamp, n. kăfo, kafau (S.), topki.

sway to and fro, intr. v. ramgaji (K.), rangucala (S.).

swear, intr. v. rantse, ranche, yin rantsuma, sāba, sähi, e.g. I swear by God na rantse da Allah.

sweat, n. and intr. v.; see perspiration, perspire.

sweep, tr. v. shara or share, yin shara.

sweeping, participial n. shara. sweet, adj. (to the taste) $d a$ zaki, tutushi, (nice, agreeable, grateful to any sense or feeling) da dadi.

sweetly, adv. da dadi, e.g. the bird sings s. tsuntsuma tance vaḳa da dadi. sweetmeat, n. allewa, alewa; spec. a s. made from the ayd reed dakuu a.

sweetness, n. (taste) zaki, dadi, the last gen. and of taste too, e.g. thou shalt taste of its s. $z a$ ka sha dadi nata.

swell, intr. v. 1. kumbura or kumbure; (of a sore, etc.) kaba.

2. fig. (to be inflated with pride, etc.) kumbura, e.g. thou swellest with pride because it is said thou excellest all kana kumburawa uai ka fi kowa; the same may be expressed by means of chichilia (lit. be filled with).

swelling, kumburi, kumburiya; (with sickness) kabuua; a s. caused by guinea-worm hangara; a s. on the back doro; a slight s. on the body or itch kazuma, yüda (S.) ; a s. in front of a man's body (elephantiasis) grugi; a s. on hand or foot lakari; a s. on the foot kurkushe; a s. on the throat hangum*; cf. also kuvikuri, kullutu.

swept, pass. part. shararre, fem. shararra, pl. shararru. swim, intr. r. ixo, yin iyo, 
futo, yin linḳāya; I can s. ua iуa ruece.

swimmer, an expert gurunin ruca.

swimming, n. iyo, kurme, linkāya, ninķaya.

swindler, n. mai-zambachi or mai-zambata, mai-zamba.

swine, n. (domestic) gursunu, see pig.

swing to and fro, tr. reta, intr. wo, lilo.

swinging, n. reto, shillo. switch, n. (i.e. one for driving away flies, made from cow's or horse's tail) izya, tsagiya (S.). swoop, (e.g. of a hawk) bura masc., sura.

swoop, to kawo sura.

sword, n. takobi, pl. trekublua, kansăkali; spec. a s. with a broad blade findi; a s. with a double sharp edge tagomers, tryomashi, tremya, tamoyashi; s. with one cutting edge trmalaulo; a cheap, roughly made s. tăma; a rasp for sharpening s. magagari; to draw a s. zare, zucure, zari, takobi; a curved s. worn by Arabs bisalami* ; a wooden

s. pauma.

sword-sling, n. hermilr. synonym, sauwi.

syphilis, n. chiuetan birui, tumjere, kaba, kabune, man- gyau, mingyau, manjau (K.), maigyau. (S.), chusayi (K.); a medicine for s. riga kafi. syrup, n. madya*.

table, n. rumfa, rumpa, pl. rumpuna or rumfuna, maida*. taciturn, adj. (habitually silent) turn by tarka q.v., e.g. he is t. ya tarka (yin kurum, yin shiru, kurum or) shiru.

tackle, n. (implements, instruments, apparatus) kaya, pl. kayayeki or kayayaki.

tail, n. urtsiya; cow's or horse's t. used as a switch izga, tsagiya (S.).

tailor, n. madumki, fem. madumkiya, pl. madumkai.

take, tr. v. gen. (seize, lay hold of) kama, samu, dauka, dauki, loka, dau or do, karḅa, karḅi, amshi, make; to t. (of an object running away, about to escape or resist) kama; (with the added notion of reaching, overtaking, finding, samu; (of taking or picking up an object from the ground, a table, shelf, etc.) dauka, loka, chăfa; to t. up and carry away kuashe; to t. and bring kucaso; (of receiving) karba and especially as an imperative karbo q.v., also 
ungo, ingo (S.); to t. back tumbe ; to t. (conduct, guide) $k a i$; to t. (of game, fish) kama; (of road, way) id., e.g. he took his road (pursued his journey) ya kama hanya; (of medicine) if liquid sha and hade, if solid hade; cf. the fire caught urta ta kama; t. and bring tariyo*, kankamo; to t. a thing to gabata da; to t. away kai, kawa, kauda, kaushe, kawas, kawas da, jüshe, fige or figi, dauka, doka, gushe, jidadda, tafi da, e.g. he took it away ya tafi da shi; fitca da, fishe; to t. away by force kuache or kwashe, amshe; to t. down (gen.) shida or shide, shido; (a tent) nade; to $t$. for oneself dauko; to t. hold of dauka or doka; to t. in (to let or bring in) shigas da; to t. off debe or debo, daibo, fuda, fitas da, fisge, fizge or fusge; (garments) tulye; to t. off garments as sign of grief takaba; to t. off a load, etc. zubda; to t. out fidda, fǐtar da, fĭtas, fütas da, dèbe, dèbo, dība and daibo, fisge, fizge, fusge, tsami; t. up and bring it here! dēbo; to t. a little of gutsura; to t. to oneself karbo ; to t. up dauka or doka; to t. up with hand or spoon mara; to t. a handful dimtso; to t. care, heed or notice of tuna $d a$, kula da; (in proclamations 't. notice that') $\ddot{j}$, jiya, saurara, sorara; he was 'taken in' banza ta shashe shi.

taking away, participial $\mathrm{n}$. karbawa, amshewa.

tale, n. (story) tatsuniya, pl. tatsuniyoyi, riwaya; to tell a t. riya; (of fiction, unreal or false t.) kariya*, fira or hira, see story.

talebearing, annamimi, annamimanchi; telling tales against anyone kwarmăto.

talent, 1., see ability 2.

talk, $\mathrm{n}$. (= con versation, mutual discourse) zanche or zanchi, batu, roshi, and in a less precise sense magana; loud t. lumi, see talking.

talk, v. (converse) zanche, tanka or tamka, the first with forms in $n a$ or with $y i$, e.g. I am talking with my friends ina zanche (or ina yin zanche) de rebokaina, zantave with forms in na, yin batu, yin magana, e.g. we talk in Hausa muna yin maganar. Наиsа; he talks nonsense 
shina magana barkatai; (palaver) al'amari*

talkative, very, adj. maigaraje* (S.).

talkativeness, saniya*, sururi (S.), surutu (K.).

talking, participial n. (conversing) fadi, fade-fade, kuchi, pl. kuche-kuche, zantaua; much t. tankiya; noise of angry or loud t. hargona, haya-haya.

tall, adj. dogo, fem. dogurea, pl. dogaye, zarau, pl. zarazara; the comparative taller and superlative tallest are expr. by $f$, cf. H. Gr. pp. 75 , 76 ; a t. thin man yankare.

\section{tallness, n. tsawo.}

talon, n. akaifa; spec. inside of a bird's t. dunduniya.

\section{tamarind tree, n. tsumiya.}

tame, adj. (subdued, domesticated), no general term, the distinction between $t$. and wild species being sometimes expressed by different words, e.g. t. swine gursunu opp. to hanzir and gyado; t. dog kare and karen gida; $t$. animals bisashen gida.

tame, to lele; the hyena cannot be tamed kura ba ta kiyayuu'a.

tameness, 11. (easy disposition, want of spirit) lalafanchi. tan, tr. v. jemi, jīma, shema, shima, tuje*

tank, n., see cistern.

tanner, n. majemi, pl. majema, mashemi.

tanning, a tree used for, $\mathbf{n}$. bagaruwa, gabaruua, patako, šriri.

tap, to (e.g. a pot) liwankwasa. tapeworm, tsila, tamza, daudachiki.

tarry, intr. v. 1. (to stay) zamra, e.g. we tarried in 'Timbuctoo three months mun zamna chikin T'umbutu wata nku.

2. t. for (to wait for) jira and jirache.

3. (to delay) yin yauchi.

task, n. al'amari, and in a general sense aiki.

tassel, tuntu.

taste, tr. v. 1. (to try the flavour of) dandăna and dandăni, e.g. have you ever tasted pepper? kun tăba dandana barkono?

2. fig. (to experience) sha, e.g. thou shalt taste its sweetness za, ka sha dadi nata; he tasted trouble ya sha wahala.

taste, n. dandăna.

tasteless, adj. lāmi and $d a$ lāmi, da babu zaki.

taster, n. madandani. 
tasty, adj. (of food, etc., nice to taste) da dadi, da zaki.

tattoo, to kaskasta, shaushauta. tattoo marks, akanza, see under marks.

taut, tam, tamau-tamau. tax, n. humushi, haraji; spec. a t. paid on leaving a country garama, fito; the latter also $=a$ t. which used to be paid to the king in the Kano market when buying a slave; a caravan t. fäto; a t. on cows jangali; a t. on an inheritance tirka; see taxes.

tax, to tirkata.

tax-collector, n. mai-karbar garama.

taxes, n. gen. kurdin kasa, jinga; to pay t. yin jinga.

teach, tr. v. koya ma, bada koyo, karantas da, karantasa, karantashe, almajirtad da, sanas da or sanda*.

teacher, n. mai-koya, mai-foro, mafori, shaihu*.

teaching, n. (the act of teaching) koyauca; (doctrine) koya. teal, the whistling t. jalili, kirinjijiya, the latter also $=$ the African tree duck; a species of t. kuarra (S.).

tear, n. (also coll. = tears) hawaye; with tears da hawaye; to shed tears yin hawaye. tear, n. (rent in clothes, etc.) yaguua, dan barki.

tear, tr. v. (clothes, paper, etc.) yaya, yage, tsāga, tsāge, tsagagye, chage, keta, katsa, katse, keche, kiche, murtsuka, barke, barka, karantsaye; to t. out tona and tone; to t. to pieces tsatsaga, fatuttake; to t. up chichira.

tearing, n., e.g. of a gown, barkuwa, karantseyi, ketuwa, tsāga.

tease, to dāme, dāma.

tease, a mai-fitina, mai-ta'radi.

teeth, n., see tooth.

tell, tr. v. (to inform, also to command) fücla or fădi, furta*.

temerity, yadauniya.

temper, n. (disposition) hăli, pl. hălaye; evil t. hălin muyu ; (irritation, passion) haushi, kumchin zuchiya, e.g. he is in a bad t. with you shina jin haushinka.

tempest, n. hadari, zirnaniya ; see storm.

temple, n. (a place of worship) masallachi, pl. masallatai.

tempt, tr. v. l. (to test or put to trial) yin jaraba.

2. (in bad sense, to allure, inislead) rude. 
temptation, n. (trial) jaraba. tempter, n. marude or mairude, pl. maruda.

ten, card. num. goma, pl. gomiya; the latter is sometimes used to express multiples of t., e.g. gomiya uku. tenant, mai-ăro.

tend, tr. v. (to watch cattle) kiwo.

tender, adj. (soft, in a material sense) da tapshi (tabshi or tafshi); to be or to make t. yin tapshi; the t. leaf danye or danyi, pl. danyoyi.

tendon of Achilles, ăgara;

t. of foot matsarbaje (S.).

tent, n. lema, laima, bukka, pl. bukkōki; to pitch a t. kafa lema; to take down a $\mathrm{t}$. năde lema; spec. $t$. of skins or leather only alfarwa, pl. alfaruwa.

tenth, n. of number, 1. (one part of ten) $\breve{s}$ shuri.

2 . (one t. devoted to religious purposes, alms) zakka. tenth, adj. na-goma, fem. tagoma.

tentpole, n. tankari; shikashiki, pl. shikashikai.

terebinth, n. gwinki.

term, n. 1. (limit, end, boundary) iyaka.

2. (the time a thing lasts) zamani. termites, (i.e. white ants) n. găra (also used as coll.), pl. gărani, shinge.

terms, n. pl. (conditions, stipulations) shardi, shartu, sharatsa*.

terrify, tr. v. tsorata, bada tsoro, burga.

terror, n. 1. abstr. (the emotion) tsoro, tsantsanta, matsorachi, razăni.

2. concr. (an object of t.) abin tsoro.

test, n. jaraba.

test, tr. v. dandana, dandani; spec. to t. anything by smelling it sunsuna; to $t$. the weight of a load jijiga.

testament, (with) wasichi*.

testator, wasiya*.

testicles, gwaiwa, marena, tsugau, tsugwaigwai.

testimony, n. shaida, pl. shaidai and shaidodi; to adduce t. kai (and kawo) shaida which also $=$ to bear t., as do shaida and yin shaida, e.g. he bore or gave t. ya shaida or ya yi shaida.

tether, to tie with a long $t$. talala.

thank, tr. v. goda, gode, barka, gaida, gaishe, yin albarka, sa albarka; 'thank you' na gode ma ka or godiya; 'no thank you' albarka. 
thanks, n. pl. godiya ; expressions for to give $t$. are : 1 . (to God) gode, and with yi or pres. forms godiya followed by $m a, g a$ or zuu'a ga, shukra.

2. (to men) gode, yaba; for the Engl. phrase 'thanks' cf. prec.

that, 1. demonstr. pron. pointing out remote object wanchan, fem. wachan, pl. (= those) wadanchan; an emphatic form $=t$. one $u$ anchananka; the following = those as well as t. chan, chana or (in written Hausa) chananka, e.g. t. lion zaki chan; nan is also employed in this sense, e.g. t. business abin nan.

2. rel. pron., see under who.

3. conj. t. (in order t.), t. not (in order $t$. not), see order 3 .

4. Engl. t., as a conjunctive particle, pointing out one sentence or clause as logically the object of another, is unrepresented in Hausa, which expresses such a connection, in nearly every case, by simply placing the dependent after the principal sentence. This is so with verbs of asserting, knowing, perceiving, judging, wishing, commanding, e.g. this woman says t. she will not go on machen nan ta che $b a$ za ta tafiya ba; I said to them t. I did not perceive t. I had been struck by a shot $n a$, fadi ma su ban sani ba aka halbe ni da bindiga; I desire t. you give me my money ina so ka ba ni kurdina; he ordered t. they should be fettered ya hakumche a sa ma su gigar. In the same way may be expressed a consequence, e.g. he terrified him (so) t. he fell down ya tsorata shi ya fadi a kas; he beat it t. it died ya yi ma ta bulala ta mutu; similarly verbs of causing and the like may govern a clause, which takes the emphatic pronouns, expressing the effect, e.g. I will make hin run (= I will cause t. he run) ni sa shi shi gudu; pernit t. I depart bar ni in tafi.

That, used after to say, assert etc. chewa, this use is however very limited, cf. dominchewa.

thatch, grass used for, n. bunı, pl. bunai.

thatch, to, with grass baibaya, 
bebeya, yin jinka, yin kandama.

thatched roof, n. tanka, jinka. thatching, a leaf used for, $n$. fittc; millet stalks used for t. maiua; a grass rope used in t. jiniya.

the (definite article), $-n$, e.g. where is the woman? ina machen?

theatre, n. gidan uasa*. thee, pers. pron., see thou. theft, n. satr, sani or sucane, vallo*.

their, possess. pron. suttixed -su, -nsu, e.g. t. town garivsu; t. wives matayensu; separate, if the object possessed is masc. nasu, if fem. tasu.

them, pers. pron. suffixed to verbs and prepositions as object, e.g. hedestroyed t. yahallaka su; to t. ma su, gare su. then, adv. (at that time) sa'an nan, lokachine nan, yanda, yawan da, yayin da, yaanar; (t. and not till t. or and t.) kana*, kari*, kanda*, e.g. do my work (tirst) and t. do your own ka yi aikina kana ka yi naka; (in that case, in its weakest sense) $f a$, mana, e.g. come, t. zo mana.

thence, adv. dăga chan. there, adv. chan, dăga chan, wori chan, a wuri chan; t. is, t. are, etc. akwai, e.g. t. is a journey before us akwai tafiya găban mu; I went $t$. na tafi gurin.

therefore, don wannan, $f a$, dada.

these, dem. pron., see this. they, pers. pron. prefixed to various forms of past tenses su, sun, suka, suffixed to the aux. verb of the future, e.g. t. will... $z a s u . .$.

thick, adj. da kabri, da kauri.

thief, n. barawo, fem. barauniya, pl. barayi or barai, mai-sane, mai-sata; a t. who comes in the night lkwaro*; a receiver of stolen property dan tugu.

thieving, n. barawonchi, barauchi, sata, sane or swane; secret t. $j a$ chiki.

thigh, n. chinya, pl. chinyoyi, kătara, pl. katatari, karfata.

thin, adj. (tine, as flour, dust, etc.) laushi; (not stout) $b a$ kabri; (lean, emaciated) a rame, shalma, siviri, fem. siririya, e.g. her young were quite t. diyata sai a rame; to become t. rame, yin rama.

thing, n. $a b u$, connective $a b i n$, pl. abubuwa or abu; (in the gen. sense of matter, subject) 
tada, pl. tadodi; things created talikai*.

think, v. (to reflect, ponder) tuna, tunane; to t. of, or about tuna $d a$; (to deem) zato*, zache, tsamāni; (to imagine, expect) tamaha with $y i$ and the pronouns in $n a$.

thinness, silili (S.), siriri (K.).

third, 1. ordinal num. na-uku, fem. ta-uku.

2. fractional num. (one part out of three) sulusi*; two-thirds sulusani* ${ }^{*}$; the $t$. day, i.e. the day after the day after to-morrow gata.

thirst, n. Kishiruwa, kishirwa, kishi; to feel t. jin kishiruwa, jin kishi.

thirsty, adj. da kishiruwa (or kishirwa).

thirteen, cardinal num. goma sha $u k u$, also sha uku.

thirty, card. num. talatin.

this, dem. pronominal adj. wannan, pl. (these) waclannan, wanga, fem. wagga, walya, warga (S., Zanf.), pl. (these) wadanga; nan used for all genders and numbers usually placed after the word to which it refers, e.g. t. woman machen nan; suffixed also to the connective is $g a$, e.g. t. house gidanga; t. town garinga.

thither, adv. of place nan, chan, wurin chan.

thong, leather guru, karho

(S.), kangi*.

thorn, kaya, pl. kayayuwa or kayoyi, karangiya; spec. a tree with white thorns, from fruit of which ink is made farak kaya; a thorny bush sarkakiya.

thorn-apple, (Datura metel) zakami, haukat yaro, babba juji.

those, demonstr. pron., see that 1.

thou, pers. pron. separate and emphatic kai, fem. $k i$ or $k e$; prefixed to past and suffixed to fut. auxiliary $k a$, fem. $k i$, e.g. t., $\mathrm{O}$ woman ke mache; t. wilt return here $z a k a$ komo; t. wast stung by a scorpion an halbe $k a d a k u$ nama; the above also = thee after prepositions and tr. verbs, e.g. along with thee tare $d a k a i$; to thee ma ka; I saw thee (fem.) na gan ki.

though, conj. ko da, sai dai. thought, n. tunani, tunane, lunani*, pl. tunanu, zăto, tamaha, ruva*.

thousand, num. dubu, zambar,

R. H. D. 
alif; a t. cubits mil* (S.); two t. alfin, alfyan.

thread, n. zăre, mandawari; spec. very fine t. arafiya; coarse t. buruda.

thread, v., to t. beads zura duwatsu.

threadbare, jula-jula. thread-worm, kwaraba. threat, empty, n. narko (S.), kyachewa, alwashi, kuri (S.), ruba (K.).

threaten, v. yinn kurari, kyaclue (S.).

threatening, n. kurari.

three, card. num. uku, talāta; the latter in counting cowries often stands for $t$. thousand; t. days ago wanshekaranjiya. thresh, tr. v. dăka, dandaka, daddaka, sussuka, chasa. thresher, n. mai-taki.

threshing-floor, n. masussuka, wurin sussuka, mabuga, mabugiya, pl. mabugai, făḳo, fagye.

threshold, i.e. a raised ridge in front of a door, n. garama, dan-garama.

thrice, numeral adv. sau (or so) $u k u$, guda uku.

thrive, v. (to prosper)yin arziki. throat, n. makwaruwa (S.), maḳwarua (K.), maḳōgwaro, makoshi; swelling on t. makoko, hangum; a sore t. mashako. throne, n. kujeran sariki, kujera, kursiyi, al'arshi; heir to the t. majiran gado.

throng, n. taro, pl. tarori, see crowd.

throttle, tr. v. murda, makure. throttler, n. murdago, mirdago.

throw, n. chăka.

throw, tr. v. yas, yasda, jefa, jefi, jefe, jefo, e.g. he throws stones ya jefa duwatsu; to t., e.g. a spear chăka, năsa, năshe; to t. away yas, yasda, yāda, zubas*, zubas da*, wulga, wurga, kayas, kayas $\dot{d} a$, watsar $d a$, e.g. he threw away his gun and fled ya yasda bindiga ya gudu; to t. back mayas*; t. out (also= to cast out, overthrow) jefas $d a(\mathrm{~K})$, jefad da (S.), jefashe (Zanf.) ; to t. with dice jefa kuriya; spec. to t. (food) into the mouth hamfude, hamfudi; to t. up and catch chafi. thrower, a champion t. sarikin jifa.

throwing, n. jâf $a$, năshi, pl. nashe-nashe; t. away wulgi, wurgi.

thrush, a yellow-breasted chat t. gabachara, gwanno.

thrust, tr. v., see push; to t. through (pierce) soka, soke or soki, e.g. he t. their chiet 
through with a spear ya soka babbansu da mashi.

thumb, n. babban yatsa.

thunder, n. tsawa; distant rolling t. chidda; a burst of t. or thunder-bolt arādu. thunder, to yin arädu.

Thursday, n. alhamis or ranar alhamis.

thus, adv. (in this or that way or manner) hăka, hăkanan, kaza; the last is also used (see under so, such) where the speaker mentions the way or manner, but the actual author of the account avoids it, e.g. he said the king spoke (t., or) t. and t. ya che sariki ya fadi kăza da kăza; (in a weak sense $=$ so then) $f a$. thy, possess. pron. suffixed $-k a$, $-n k a$, fem. $-k i,-n k i$, e.g. t. wife matakka, t. husband mijinki; separate, if the object possessed is masc. naka, naki, if fem. taka, taki.

thyself, 1. reflexive kanka, fem. kanki.

2. emphatic kai da kanka, fem. ke (or ki) da kanki; see self.

ick, (insect) kaska.

ickle, to tsikara (K.), tsakara (S.).

ickling, tsikari (K.), tsakari (S.). tidings, n., see news.

tie, tr. v. damre, daure, damra, darmi (S.), tanka, tanke, rataya, balla, sarkafe; to t. up together layache (K.), goya, goye; spec. to t. up kumsa, kumshe, to t. the hands together bankare; to t. grass in thatching tsāra, tsāre; to t. two pieces of string together kulla; to be tied together kullu; to t. in a knot kumbuche; to t. up a bag tsuke; tied up kumshashe, fem. kumshashiya, pl. kumshashu. tied, participial adj. sassabta, ballu.

tiger-fish, (Hydrocyon lineatus) tsagye; a species of t.-f. kawara (Alestes dentex).

tiger-nut, aya.

tight, adj.(used of a string) kyar,

(taut) tam, tamau-tamau.

tightness, runtsi.

till, prep. and conj., see until. till, tr. v. noma, nomi or nome, maimai.

tiller, n. (i.e. of the ground) mai-noma or mai-nomi, pl. masu-noma.

tilt, to $t$. anything up against

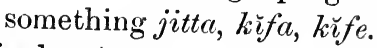

Timbuctoo, pr. n. Tumbutu. time, n. lōkachi, wakati, wakti*, wakachi, sa'a, yayi, zamani, zamanu*; a short t. zamani 
kădan, jĭmawa; at that t. lokachin nan, sa'an nan; at the $t$. when he returned here lokachin da (or sa'an da) ya dawayo; at what t.? wache sa'a? some t. wani yayi; (period, age) yayi, zamani, e.g. in the $t$. of the prophet ga yayin annabi or zamanin annabi; his t. is passed (i.e. he is old) yayinsa ya wuche; (set t. or proper occasion) loto, wakati, wakti*; every t. wakati duka; by (or about) this t. warhăka; at any t. ko yaushe; at what t. (when) yanda; at what t.? yaushe? before-time wuri; in former times or some $t$. ago da wuri or dauri; from a long t. dadadde; from what t.? daga yaushe? since what t.? tun yaushe? until what t.? har yaushe? one at a t. gŭda gŭda; length of t. tsawa or tsawo; I have not t. to $b a n i$ da dama; what t. is it? karife nawa? do not come before your t. kăda ka rŭgaya lokachinka; see also times, hour. times, pl. (of repetition) sau or so, gŭda, e.g. five t. sau biyar, or gŭda biyar; how many t.? gŭda nawa? timid, adj. matsorachi. tin, n. chinkal, sinādari* ${ }^{*}$, shin $\bar{a}-$

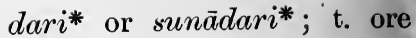
kuza.

tinder, n. alfawami. tinge, tr. v. rini, rina. tinged, pass. particip. rinanne, fem. rinanna, pl. rinannu. tinkle, n. dirdindin. tip, n. (of the finger) dan yatsa, (of the ear) dan kunne. tire, v. intr. (to be fatigued, weary) ğăje, găji, jin găjiya, dăgagaji, e.g. he was tired with travelling ya găji da tafiya; we are tired with over-work muna jin găjiya da yawan aiki; to be tired of waiting kosa.

tithe, n. 1. (tenth part) ushuri.

2. t. or tithes (one-tenth devoted to religious purposes, alms) zăka.

title, n. (name, appellation) suna, pl. sunuwa or sunanaki to, 1. prep. $g a$, with pronoun gare, used of both persons and things, e.g. he came tc me ya zaka gare $n i$; neal to the bank of the river kusc ga bakin ruwa; wa (no before personal pronouns specially used after verbs t. tell ; do not tell anyone kăd ka gaya wa kowa; ma, ap plied not to persons but $t$ things, mostly to pronoun e.g. to me $m a n i$, also mini 
to thee $m a k a$; $m a$ sometimes expresses the datives of advantage and interest, e.g. grant to me an abatement ka yi ma ni rangwame; $a$, found in a few phrases, e.g. he fell to the ground ya fadi a kasa or a kas, sometimes prefixed to gare, e.g. to thee $a$ gare $k a=$ gare $k a$; after verbs of motion etc. the English to may be wholly unrepresented, e.g. he went to his house ya tafi gidansa; they swam and came to land sun iyo sun kai ḳasa.

2. conj. (in order that, so that, so as to) in placed immediately before the verb and rarely used except with the 1st person, see under order 3 .

toad, n. pasha, kwado.

to-and-fro, going t. yauchi.

tobacco, n. $t \bar{a} b a$, t.-pipe $t u$ kunyar tāba; to smoke t. shan $t \bar{a} b a$; a stick of rolled t. sandan $t \bar{a} b a$; seed of $\mathbf{t}$. plant tamna-gardi.

tobe, n. riga, pl. riguna; spec. a black or blue t. rigal saki; a $t$. of black or shiny blue cloth kore; a red t. jabba*; a white t. gare, pl. garuruka, girke; a white t. with short, lined body and wide single skirt kwakwata, kwakota; embroidery on a t. sharaba, tambari; the pattern on front of a t. fuskar riga, kwashe, linzamin riga, mumbari; double thickness of cloth in a t. sabăda; for various kinds of tobes see under riga. to-day, adv. yau, also pronounced yo ; existing t. maiyau.

toddle (or to walk on all fours), intr. v. dǔbo dǔbo.

toe, n. yatsa, pl. yatsotsi or yatsu, yatsa na lafa; big t. babban yatsa; spec. a disease of the toes kudumbiya, kumbudiya*.

together, adv. tare, gaba dai, gaba daya, jeni; t. with tare da, gami da, game da; v. to put t. tara; to put up t., to gather t. gangama; to be gathered $t$. (to assemble) taru; to come t. with violence kara or karo; to go t. tare, hăda tafiya, e.g. we will all go t. duka za mu tare; keep together! ku tafi jeni; collecting t. jama' $a$; a hundred rose up t. zango ya tashi tsaitsaye.

toil, n. (fatigue) ta'ba*.

toil, intr. v., see labour, e.g he toils after vanity shina dawaniya da abin wofi. 
token, n. shaida, pl. shaidai and shaidodi.

toll, n. humushi (lit. one-fifth), see tax.

tomato, n., the bitter native t. gauta, pl. gautaye, gautan kura, kulufita* ; a plant with a fruit like large t. yalo, pl. yaluna.

tomb, n. kushewa or kusheya*, pl. kusheyi, kushewoyi, wurin kushewa, wurin bisne, kăbari, $k a b r i$.

to-morrow, n. gobe, kashegari (K.), wanshekare (S.), cf. prov. yau da gobe kayan Allah; the day after t. $j \bar{\imath} b i$, the day after $j \bar{\imath} b i$ is called gata, that after gata, i.e. the third day after t. chitta. tongs, n. awartaki, hantsaki. tongue, n. 1. (the bodily member) halshe, harshe, pl. halshina, halussa.

2. (a particular language) see language 2.

too, adv. 1. (likewise) kuwa, kuma, ma.

2. (more than enough) express by the verbs faye and buwaye, e.g. it was t. severe for me ya faye ni karifi; he was t. big ya faye yirma; he was $t$. much for me ya buwaye $n i$; t. much ya faye yawa. tools, n. pl. kaya or the pl. kayayeki.

tooth, n. hauri, hakeri, pl. haǩra, zaga, pl. zagogi; a molar t. matamni, pl. matamna; back teeth turame* spec. a tree the bristles of which are used for rubbing the teeth dashi ; t.-gaping, n., used of one who has lost two teeth gibi, e.g. shina gibi i; a t. that has been filed fike; eye t. gaboba; a wide space between two front teeth wushiriya.

toothless, adj. mai-dasashi. top, n. kai, pl. kanuwa, kawana and kawuna, kōroruwa, tsololo, tsororo, pl. tsololuwa, tuluwa (K.), b̌sa; on the t. of a kan, b̌sa or a b̌sa; a spinning t. makodi*. toper, a mashayi, pl. mashaya. topple over, to, intr. v. yin kunduma.

torch, n. bakin wuta; a display of torches wowo (K.), wauwo (S.).

torment, n. tsanani; spec. place of $t$. for unbelievers gumki*, gamki*, gwauki*; to suffer t. jin tsananta. torment, tr. v. tsananta, tsane, tsani, tsananche, hăsada, arja (K.), alja (S.). tornado, n. hadari. 
torrent, n. Korama; noise of a rushing t. bandam-bandam. tortoise, n., a land t. with convex shell kunkuru; a water t. with flat shell or mud turtle kififiya, yuma (S.); a small t. kafarji*, farkaji; the shell of a $t$. kwachiya, kwariya.

toss, tr. v. (of cattle, etc. when butting or goring) tunkuda, tunkwiya.

total, n. dokachi (sum or amount reached by reckoning), see calculation 2.

totter, to, adj. (applied to the walk of the old or blind) kǔtup kǔtup; (of walls, etc.) karkache.

touch, tr. v. tăba, tăbi; to engage slightly in, id., e.g. he just touched the work ya tăba yin aiki.

towards, prep. ga, before pronouns gare, e.g. some men are coming t. us wadansu mutane suna zakuwa gare mu. towel, n. bante, banche, pl. bantuna, kalkăfi.

tower, bene; a watch t. $m a$ băga (S.).

town, n., a large, walled $t$. birni, pl. birane or birnuwa; a small, unwalled t. gari, pl. garuruwa and garigaru; a quarter of a t. shiya, pl. shiyoyi, unguwa; a frontier t. kain iyaka.

toy, n. (plaything) abin wargi. track, n. (beaten path) tafarki, pl. tafarkoki; a broad beaten t. rimai, godabe; (a spoor) lawali; let him not go back on his tracks kăda ya bi sawunsa na da.

trade, n. chiniki, juura, korami, sana'a, fatauchi.

trade, intr. v. yin chiniki; to

t. successfully chin kasuwa. trader, n. falke, fem. falkiya, pl. fatake, mai-fatauchi, maichiniki, mai-dillanchi*, sambani, tajiri, dan kasuwa, mashimfidi.

trading, n. fatauchi, dillanchi; corn t. kwarami, traders in corn yan kwarami.

tradition, n. (doctrine orally handed down) sunna, tariyo*. traduce, tr. v., see calum. niate.

trample, tr. v. taka, bijigi, intensive form tattaka or tattake, e.g. let us not t. it under foot kada mu tattake shi.

transform, tr. v. riǩ̀da, sauya and sawaya, e.g. by the power of a charm he transformed himself into an elephant da ikon magani ya sauya kansa giwa. 
transformed, pass. particip. rikidadde, fem. rikidaddiya, pl. rikidaddu; to be t. sauya and sawaya, mayas da, rikida, e.g. he was t. into a sheep ya sauya tumkiya; she was t. into something or other $t a$ mayas da wani abu, see also change 3.

transgress, intr. v. (to do wrong) yin laifi, (to commit sin) yin zunufi.

translate, v. mayas $d a$, see interpret 1 .

translated, pass. particip. sauyayye, fem. sauyayya, pl. sauyayyu.

transport, n., oxen used for $t$. takarkari, pl. takarkarai.

trap, n. hako, pl. hakoki, fig. (a thing leading into harm or error) id. ; a t. consisting of a hole in the ground burma or buma*, mashako; a t. for wild animals tarko, pl. tarkuna, burma; to lay or set a t. hako with yi or the forms in $n a$; a fish t. sankuja (K.); a t. consisting of a hole and noose taskira.

travail, n. 1. (severe labour) see toil.

2. (pains of childbirth) wahalan haifuwa, nakudar haifuwa; to be in t. nakuda. travel, intr. v. tafi; also tafiya with $y i$ and the forms in $n a$, e.g. as we were travelling much rain fell da muna tafiya an yi ruwa dayawa; spec. money paid to a king for permission to t. garama; to t. hard yin haramat tafiya. traveller, fellow, n. abokin tafiya, maraki.

travelling, n. tafe, pl. tafifiya. travelling-ant, $n$. (or driverant) kwarkwasa, kwalkwasa ; a red t.-a. makwaiwa.

treachery, tsēgumi, pl. tseyunguma, yaudara, kissa. tread, v., to t. down taka, taki, take, intens. tattaka, tattake, bijigi, dăbe; to t. upon (to crush) latse.

treasure, n. wada, wada'a, taska; treasures ajiya, azawa; royal t. stored up kambi*; spec. chamber for storing $t$. rafoniya, pl. rafoni; to lay up t. taskache; t.-trove galala. treasury, n. taska, pl. taskoki. tree, n. itache, iche (the former is sometimes used as a plural of iche esp. in Sokoto), pl. itatuwa; in this sense the word is masc., a stick cut from a t., i.e. itache is usually regarded as fem.; a dried-up, withered t. koren itache; a t. used to hang meat on 
jigo, pl. jiguna; a pair of trees so planted as to grow into one găminbauta; a bent t. kwandariya, kondariya.

The following are some of the more common names of trees found in Nigeria: various species of ficus, e.g. chediya, gamji, durumi, ķawuri, shirinya, uwar yara, wa, rubiya; various species of acacia, e.g. gawo, dakwara, farak kaya, tawasa, dorowa, gabaruwa, bayaruwa, dundu, kiriya; the baobab t. kuka; various species of euphorbia, e.g. kumkumiya, fida-sartse, fida sarde (S.), kirana, kyanara (S.), tinya; the copaiba t. kadaura, maje; a t. with yellow hard-shelled edible fruit (Strychnos spinosa) $k 0$ kiya; the bloodwood or African rosewood t. madobiya; a t. (Vitex cienkowskii) from the fruit of which molasses are made dinya; a t. (Detarium Senegalense) from which molasses and gum are obtained taura; the 'ebony tree' kainya or kanya; a tall, straight t. dilo; a large t. with flat, winged fruit(Terminalia macroptera) baushe; a t. with yellow plum-like fruit (Spondias) danya; a large, bushy t. (Zizyphus spinaChristi) with red edible berries kurna; a t. with long thorns, white flowers and edible leaves chizaki; a t. (Zizyphus jujuba) the fruit of which is made into cakes magariya; a small t. with reddish wood and edible leaves (a chew-stick) marke; a sinall t. from which blacksmith's charcoal is made kirya, kariya ; a t. from the bark of which small ropes are made tawatsa; the silk-cotton $t$. (Eriodendron orientale) rimi, pl. rimaye; a red-flowered silk-cotton t. gurijiya; a t. the leaves of which furnish a yellow stain and, mixed with indigo, a green dye magina ; a small t. (Bauhinia reticulata) the leaves of which are often used for wrapping food and the bark of which is used as a stain to darken lips kalgo or kargo; a t., with reddish bark (Hymenocardia acida), used for shed supports etc. janyaro; a t. (African bdellium) the bristles of which are used as a tooth-brush dashi; a large t. the aromatic bark of which is ground up as a medicine fasa-kwariya or pasa-kwari; 
a t. with fragrant flowers and leaves and a black or purple berry (Eugenia owariensis) malmo, marmo; the horseradish tree (Moringa pterygosperma) zogalagandi; a small t. with yellow blossoms, an infusion of its leaves (Cassia goratensis) used by women near childbirth runhu.

trek, to yin tafe.

tremble, intr. v. (with terror; cold, etc.) firgita, raura, zazzaga.

trembling, participial n. (from terror, cold, etc.) raurawa, kaduwa, adj. form makarkata, makyarkyata; t. all over zazzagawa; t. (from excitement, agitation) karăya.

trench, a hafaru*.

trespass, intr. v., e.g. on a forbidden area kutsa, see transgress.

trial, n. (a putting to the proof, testing) jarabi, jaraba; to make t. of, v. yin jaraba.

tribal marks, $\mathrm{n}$ pl. (cut on face) shaushawa, kyaskyastu (K.), kyakkyastu (S.), (cut from corners of the mouth) yambaka, see also hawayen zaki.

tribe, n. iri, pl. irare, kauwi*, kabila.

tribunal, n. ưrin shari'a. tributary, adj., a t. stream hannun rafi.

tribute, n. humushi, gandu, tuda, biko, jiziya (S.), kurdin kasa ; t. money kurdin gan$d u$; spec. t. paid by the heathen tara, tar̆o ; see tax. trick, n. (dexterous artifice) wayo ; tricks wasa-wasa. trickery, n. (fraudulent deception) barkwanchi.

trickle, to tarāra, tarāro, zurare, see leak.

trim, tr. v. (to put in order) gyarta.

trinkets, coll. kayan ado; see ornament.

trip, intr. v. tuntsure, yin tuntube, the last is used as a tr. and intr. v.; to t. a person up tade.

Tripoli, pr. n. Tarabulus or birnin Tarabulus.

triumph, n., see victory. trodden down, takakke, fem. takakka, pl. takakku. trombone, kakaki*. troop, n., see company. trot, intr. v. (of a horse) kilisa. trotting, rishi, sakaraftu, sassaka.

trouble, n. (distress) wahala, hawăla, tsananta, kinḳe, alale, sanadi, sawarwari, tono ; to be in t. yin wahala; to feel t. jin wahala, tangara*. 
trouble, n., one who is in t. mai-wahala.

trouble, v. tr. wahalda, wahalsa, wahalshe, tsananche, tsananta, hasada, alale, arkăna, gayara, kinḳe, sawarwara, shamache, shamata, fitina, haiyata; do not t. (i.e. feel distressed) kada $k a w a-$ halda kanka; (as a polite exp. = spare yourself the t.) kiyaye kanka.

troublesome, adj. da wuya. trough, n. komi, jirigi, jirgi, pl. jirage.

trousers, n. (i.e. the loose, baggy native t.) wando, pl. wanduna, buje (K.), dunhu; two pieces of cloth sewn on at the bottom of native $t$. kamun kăfa; trouser-string mazargi; t. embroidered up to the top wando mai-kamu; a fold in the waist of $t$. through which the cord (zariya) runs kubaka.

true, adj. gen. da gaskiya, da gaske, gaskiya and gaske, (of persons, veracious, sound, honest) mai-gaskiya, (faithful) salihi*; t. as an adverbial phr. (i.e. quite right) ainin as well as the words given in seq.

truly, adv. da gaskiya, da gaske, gaskiya, gaske, ashe, ainin, hakīka, aiwa, ainin, wallahi, labudda.

trumpet, n. kafo, pl. kafoni or kafuna, kakaki.

trumpeter, n. mai-kafo, maibusa, mai-shantu (lit.blower); a mounted t. masarchi.

trunk, n. 1. (a small box, usually of leather) sanduki, sanduki (S.), pl. sandukai.

2. (proboscis of elephant) hănnun giwa.

3. (the $t$. of a tree) kore or koren itache, kututtura. trust, n. (confidence, certainty of safety) amāna, shaduda or saduda, dangana, (a deposit of money etc.) sabtu, saptu, sautu, sotu; he betrayed t. ya chinye amāna, I left money with them on t. na yi ma su sabtu.

trust, intr. v., or t. in (i.e. rely on) dōgara, dangana, shaduda or saduda, ingata*, sakankanche, I t. in God ina dangana da (or ga) Allah; follow Mohammed, t. in him ku bi Muhammadu ku sakankanche.

trustee, n. madaukan bashi. trustworthy, adj. (to be relied on, depended on) yardaji, ingatachi*, tabbatache, fem. tabbatachiya, e.g. this account is t. wannan labari ingatachi; 
t. language magana tabbatachiya.

trustworthiness, inganchi. truth, n. gaskiya ; to speak the t. ba gaskiya; to establish the t. gaskata or gaskanta. try, tr. v. (make trial of), see trial; (endeavour) yin kokari, taba kokari; t. diligently to follow his tradition $k u$ bada kokarinku ga sunna tai. tsetse-fly, tsando, aworo.

Tuarek, n. gent. Azbin, Asbin, Ba-Azbine, pl. Azbinawa, Asbinawa.

Tuesday, n. ranar talata. tuft of hair, n., a t. on the head tukku, tukkuwa; t. o. $h$. in the middle of the head zanko; see hair; t. of grain geza, pl. gezuna, tuntu.

tug, tr. v. (to haul along) $j a$; see draw.

tumour, kurji, gyambo, jambade, see abscess.

tumult, n. (noisy clamour of a multitude) hargowa; t. (e.g. of war) farmaki, rigima, falmaki.

turban, n.rawani, pl.rawunna; spec. a white muslin $t$. with red edges zabuta; t. of white muslin harsa, hassa; white stuff for making $t$. mabaras; a variegated cloth used for making turbans, barmushi; twisting of a double black and white t. round the head barna, funi; a black and white t. mahawara; the winding of a t. nannăde.

turkey, n. talotalo.

turmeric, gangamau, ganga$m u$.

turn in, a, at the edge of a garment, n. shafi.

turn, v. l. tr. (to move round) maida; to t. away from juya $m a$; to t. the head away from kau da kai; to t. back, or t. over juya; to t. upside down jiche, jichi, jirkiche, kĭfa (K.); to t. over (e.g. a mat, piece of cloth etc. for the purpose of folding) linke or nimka; to t. round, or t. over bankada, bankade, kífa, kuffe; intr. to t. aside (off the road, or out of the way) ratsa, rache, ratse, baudi, karkache, e.g. we t. aside from Kano mun ratsa Kano; to t. back tankwashe; to t. over kewaye or kewayi; to t. round (to revolve) id., e.g. my head turned round (of giddiness etc.) kaina ya kevaye; to t. round (of a single change of position) waiwaya, waiga, e.g. when he called me I turned round and saw him 
da ya kira ni na waiwaya na gan shi; to t. out (to become eventually) füta, e.g. he turned out well ya fúta nagari.

2. (to change or change into) tr. and intr., seechange. turning, participial n. juyawa, jujuyau: waiwayawa, waige (K.), pl, waige-waige.

turtle, n. yuma (S.); mud t. kififiya.

turtle-dove, n. kurchiya, pl. kurchecheki and kurchiyoyi, uala, pl. walu.

tusk, n. zaga; an elephant's t. haurin giwa, hauri; cf. ivory. tweezers, matsefata.

twelfth, ord. num. na-goma sha biyu, fem. ta-goma sha biyu. twelve, card. num. goma sha biyu, also sha biyu; t. times sau goma sha biyu.

twentieth, ord. num. na-ishirin or na-ashirin, fem. ta-ishirin. twenty, card. num. ishirin, ashirin; in counting by twenties hauya and lăso (= a score) are especially employed, e.g. hauya $u k u=$ sittin.

twice, numeral adv. sau biyu. twig, n. tsumanjiya, tsumajiya, tsumagiya, reshe, rishe, kivare. twilight, n. (that before dawn) jijifi also jifjif, alfijir. twinkling of an eye, $n$ moment of time) kyaptawan ido or keptawa da gani.

twins, n. pl. tugwaye, tawaye, spec. next child born after twins gambo, gumbo*.

twist, tr. v. gusda, kitso (e.g. the hair); to t. the neck nadige (K.), murda, murde (K.), mircle (S.), murgude, kwakwume; to t. thread, etc. murje, burka, năde, yin nădi, lauya; (in plaiting rope, etc.) tubka, tufka, tupka, tumka, tukka, darza; intens. form mummurda; twisting cotton round a pin before spinning kulla.

twisted, adj. a murgude.

twisting, n. nădi; t. of strands into threads třka, tukg̣a. two, card. num. biyu; by twos biyu biyu; t. hundred dari biyu or metin; t. thousand alfin.

tying, kumshi, see tie. tyranny, alfarma, yaji.

udder, n. nono, pl. nonuwa, hantsa.

ugliness, kwarjini, muni, mugunta.

ugly, adj. da kwarjini, mammuna, mummuna, da muni. ulcer, n. gyambo, pl. gyambuna, mele; corneal ulcer hakiya; see scab. 
umbrella, n. lema*, laima*, tuta* or tuti*, pl. tutochi. unabashed, da kwarkwasa. unable, to be găza, kasa; I am

u. to go na găza tafiya; they were $\mathrm{u}$. to overcome sun gaza isa; buwaya, e.g. I am u. to do it na buwaya.

unalloyed, adj. safi; see unmixed.

unbaked, an u. pot danyen kasko.

unbecoming, adj. haram, ba daidai; e.g. he did what was u. ya yi abin da ba daidai ba. unbeliever, n. käafiri, pl. käfirai, kāfirawa; to become an u. kafirta.

unbind, tr. v. kunche, kunchi, kwanche.

unbound, pass. part. kwanche, fem. kwanchiya, pl. kuntu. uncertain, adj. da zuchiya

biyu; I am u. ina da zuchiya biyu; to be u. yin tantama. uncertainty, n. (a state of doubt) kokanto, tambaba, tantama, tachetache.

unchaste, adj., see profligate. unchastity, n. zallantaka. uncle, maternal, n. rāfani, kawu; (father's brother) $b \bar{a}$ bani.

unclean, adj. (dirty, foul) da dauda, kazāmi; ceremonially u. haram, da haram. uncleanness, n. (in a physical sense) dauda; (in a wider sense) kazamta, ḳazanta, tozari, jăraba, jaïra, janaba. uncooked, adj. danye; $\mathrm{u}$. flesh nama danye.

uncover, tr. v. yaye.

under, adv. and prep. kalkashin (S.), k̦arkashin (K.), kas. underneath, adv., cf. preceding.

understand, v. ji, fahimta or fahumta*, hankalta, yin tšmi, e.g. I u. your words, I u. quite well na $\dddot{j} i \mathrm{ma}$. ganakka sarai; he understood (i.e. you need say no more) ya yi kărin magana; to $\mathrm{u}$. well intens. sansanche; to fail to u. gigiche or gigi, rudi*, gagata, the last taking $d a$ before object, e.g. I failed to $\mathrm{u}$. it na gagata $\mathrm{da}$ shi. understanding, n. 1. (comprehending, comprehension) $f a$ himchi, jiyayya, tsĭmi, kari ; (knowledge, cleverness) azanchi; lack of u. gigi, see also ability.

2. (a good u.) jiyayya. undo, tr. v., see untie; (to annul, render vain) wofinta; (to ruin) bata.

undress, v. debe or debo, tube, fitas $d a$ all with riguna, etc. 
undressed, pass. particip., see naked.

uneven, adj. (of a surface) $d a$ kurzuna, see rough.

unfasten, to balle.

ungird, tr. v. sunche, e.g. he ungirded his camel ya sunche rakuminsa.

ungrateful, adj. butulu, maibutulchi.

unintelligible talk, baubawa, bobawa.

unique, adj. kadaichi.

unit, gŭda.

unite, tr. v. gama; intr., to u. closely garwaya.

unity, n. dayanchi*; spec. to profess the $u$. of God tauhida* or tauhidi*.

unkind, magaya, magauchi, pl. magata.

unlawful, adj. da haram or haram; n., anything u. or what is u. haram or haramu, abin haram, shirku; u. gain or profit haramiya.

unless, conj. sai, sai ko, e.g. he is not without reason, u. he refuses to listen to that which thou showest to him ba shi rasa huja ba sai ya ki jin abin da ka nuna mai.

unload, tr. v. gen. shida or shide; to $\mathrm{u}$. camels, etc sabka, sabki, sapka, safka, sauka, sauki. unloose, katsi, see untie. unlucky, something u. shu'umi. unmixed, adj. (pure from admixture) tsalka, tsatsalka, safi, ǩŭna; u. water kŭna ruwa. unprofitable, adj. babu anfani, da babu anfani, banza, babu riba.

unravelled, to become u. warwari.

unripe, adj. danye or danyi, pl. danyoyi, danyu; u. fruit jimḅiri (S.).

unsaleable, ya ki sayuwa.

untidiness, barkatai; cf. everything in his house is untidy duka gidansa barkatai ya ke.

untie, tr. v. kunta, kunche, kwanche (K.), sunche or sinche, balle, katsi, bainye, banye. untied, pass. particip. kunche, kwanche, fem. kunchiya, pl. kuntu.

until, till, prep. and conj. har, hal, kamin, prep., e.g. he followed the true path u. now ya bi hanyar gaskiya har yanzu; conj., e.g. let them quarrel $u$. they are tired $a$ bar su su facla har su gaji; sai, prep. with nouns of time, e.g. u. to-morrow sai gobe; u. evening sai mareche; these expressions are elliptical, some such v. as wait, etc. 
being understood before them, as is the case also when sai is used as a conj., e.g. give up delaying $u$. you are old bari jira sai ka tsufa; kana, kan*, kanda, kamin, conj. $=$ then and not $u$. then, so that the corresponding English sentence contains a negative, e.g. don't eat our bread $\mathrm{u}$. you have eaten your own ka chi gurasanka kana ka chi tamu.

untimely, an u. birth kwatan$\tan w a^{*}$.

unto, prep. (a strengthened form of to) $g a$; with pronouns gare, zuwa, ya zuwa; in correlative expressions combined with har, e.g. from this border unto that daga iyakan nan har ga iyaka chan.

untrue, adj. kakari*; the n. kariya (=Engl. 'a story') is constantly used in this sense, e.g. whether true or $u$. I do not know gaskiya ko kariya ban sani ba.

untrustworthy, an u. person danyen kasko (lit. an unbaked pot).

unwell, adj. rashin lafiya, maras-lafiya; see ill.

up, adv. (upwards, aloft) b̌sa, a bisa, daf; e.g. the falcon soared up shafo ya tashi b̆̌sa; he climbed $u$. the tree ya hau itache daf daf.

uphold, tr. v. (to support, e.g.

as a tent-pole) tokăra.

upon, prep. b̌sa or a b̌sa, which may also be followed by ga ; e.g. u. it b̌sa garesa ; he got $\mathrm{u}$. the horse ya hau b̌san (or b̌sa ga) doki.

upright, e.g. I stood u. na tsaya daidai.

uproot, to tumbuke.

upset, v. 1. tr. jirkiche, jiche, jichi, kifa (K.), birkichi or birkiche; to u. (so as to spill water, etc.) $z u b d a, z u b d a m a$, dole, kikkifa.

2. intr., to $u$. or to be $u$. (of men, etc.) tuntsure; (of a boat)durimi,divimi, dulmiye. upside down, to turn, tr. v. jirkiche, jiche, jichi, shiche, shida.

urinate, intr. v. yin bawali, yin bowali, yin boli, yin fitsari. urine, n. fitsari, bawali, bowali, boli.

us, pers. pron. obj. mu suffixed to verbs and prepositions, e.g. he called u. ya kira mu; to u. ma mu, or with assimilation mumu.

usage, n. (custom) ada, ta'ada, tada (S.), pl. tadodi, see custom. 
use, n. (utility, advantage, profit, gain) anfāni; e.g. what is the $\mathrm{u}$. of ink? tadawa minene anfäninta? of $\mathrm{u}$. da anfäni; of no u. babu anfäni; a man of no u. mutumen vofi; I am making u. of him ina moronsa.

use, tr. v. (toemploy), nogeneral term, e.g. they u. flesh for food abinchinsu nama; they u. skins only for clothing rigunansu duka sai da fata; they u. force suna yin tilas; he can $u$. the axe shina iya yin aiki da gatari; (to make u. of, i.e. profit by) anfāni, anfäne; (to be wont) verbal forms with kan, e.g. he used to come home at night shi kan tafo gida da dare; to be used to (to be accustomed to) saba da ; e.g. camels are used to men rakumma sun saba da mutane; which do you u.? wanne ka ke moro?

useful, adj. da anfiani, maianfāni; it is u. shinada akiba. useless, adj. babu anfäni, banza; u. toil wata reran. uselessly, to work, intr. v. sunkwiya or sunkuya.

uselessness, n. wofi.

usury, fifiko*.

aterus, mahaifa.

itility, n., see use.

R. H. D. uvula, beli, belu, hakin wuyg, kucarlon halshe.

vaccination, dashin yar-rani. vagabond, adj. grejeje, dan karma.

vagabondage, magi.

vagina, tsēle, farji.

vain, adj. (empty, worthless) banza, kakari, amère; in v. barna (K.), banna (S.) ; (conceited) see conceit.

valiant, mai-yaji.

valley, kwari, kware (S.), n, see ravine.

value, n. (estimated worth in money) daraja, antaya, see price.

vanity, n. (emptiness, worth lessness) kakari, abin wofi; (conceit, foolishness) wauta, fadin kai, see conceit.

vapour, n. (mist, fog) hazo; v. rising in hot sun kawalwalniya.

variance, n. (dissension, disagreement), see discord. variation, n., see difference. various, adj. labam dabam, daban daban, e.g. v. things are sold in the market abubuwa dabam dabam a sayas da su chikin kasura. vase for scent, n. wakiya.

vaunt, to ranguada (S.), rangaji (K.). 
veal, n. naman maraki.

vegetable-marrow, kabushi, ruguguwa.

veil, n., long v. lulluḅi, lullube or lillibi, zane*; a v. worn over the mouth and hanging down in front $a m \bar{a}$ wali.

veil, tr. v. lulluba; refl. to v. oneself, id.

vein, n. jijiya, pl. jiwoji or jijiyoyi, majināya (K.); veins coll. dagura.

velvet cloth, kind of, n. kadamiskin, karamiskin, mulufi, yapki, yauki.

velvet-mite, karamiskin, karamuskin, karmuskin.

vendor, of small goods clan kōli. venereal disease, brsim, min-

yau, piyauka.

vengeance, to take, v. rama.

Venus, (the planet) n. matan wata, lit. the wife of the moon. verandah, shirai, shirayi. verify, to hakikanta. verily, adv. hakika, an che, ai, da gaskiya, see truly. vermin, see tick, etc. verse, a v. of the Koran, $n$. aya, pl. ayoyi; verses of a song tsarin maganganu. vertigo, n., see giddiness. very, adv. dayawa, most frequently with the expression thrown into a nominal form, e.g. he was v. fearful ya $j i$ tsoro dayawa, etc.; sometimes this idea is expressed by repetition, e.g. v. fast, or v. quickly maza maza; v. slowly or v. quietly sannu sannu; spec. v. red ja wur ; v. black baki kirin, baki wur; v. white fari fat; v. much (of habitual actions) is often expressed by v. faye, e.g. dogs bark v. much at nightkarnuka sun faye hafshi da dare.

vessel, n. 1. (utensil for holding anything) tukunya, pl. tukane or tukwane; a v. made of clay kasko, pl. kasake; a v. made of skin tandu; spec. a glass v. tangaram.

2. see boat.

vex, tr. v. wahalshe, refl. to v. oneself wahalda.

vexation, n.haushi; see anger. vexed, to be, intr. v. jin haushi, e.g. he is v. with me yana jin. haushina; phr. my heart is v. zuchiyata ta tafasa. vice, n. 1. (profligacy) zina.

2. (a defect, blemish) aibi, aibu.

vicinity, habarra (Ar.).

victory, n. nasara, nasarchi, bijinta; to gain a v. nasara with $y i$ or samu, e.g. he gained a v. ya yi (or ya samu nasara. 
victuals, n. abinchi, turo, chima, chimaka.

view, n., see sight 2.

vigorous, karsani.

vile, adj. kazami, duniya*.

village, n. ḳauye, pl. ḳauyuka, unguwa, anguzva.

villain, n. mai-masifa, mugun mutum.

villainy, n. (mischief, wickedness) masifa, mugunta, sheyartaka, shège*.

vine, wild v. ayana, dafara, tsibiri kinkini, chibrikinkini; edible-stemmed v. (Vitisquadrangularis) dadori; rubber v. alubada, alibada, chiwo.

vinegar, n. ruvan tsami, yami. violate, to $t \bar{a} k \alpha$.

violence, n. (i.e. tyrannical or wrongful v.) tsanani; (physical force) karifi, e.g. by v. (by force) da karifi, da tilas. violin, a musical instrument resembling a goge*.

viper, gajerc, injihau, tsadaraki, kububuwa, sha-nono, see snake.

virago, kazgama.

virgin, n. buduruwa, pl. buduruwai, kurḳiya, pl. ḳurḳoḳi, kurkiyoyi, bikira, sagara.

virginity, budurchi, buduruwanchi.

visible, to become (of a star) keto, bullo*. vision, n., see sight 1 .

visit, tr. v. jaurayi; spec. of a religious $v$. to a shrine or holy person ziyara, ziyarche. visitor, $\mathrm{n}$. (guest or stranger) bako, fem.bakuwa, pl. bakuna, baki or bakokuna.

vital, a v. spot makăsa. vizier, uaziri*.

voice, loud, n. muriya, pl. muriyoyi.

void, to make, tr. v. wofinta.

vomit, v. yin amai, (to dribble)

tumbudi, amaye, gātse.

vomiting, gashi, (e.g. after drinking poison) barā.

voracious, see greedy.

voracity, n. zouari, zuari, zari. vowels, n. hajatı*; points or

v. placed above or below letters wasali.

vulture, n. angulu, agulu, cugulu, fem. angula, agula, pl. angullai; the crested eagle angulun kucakua; the fishing v. jayaki, meke, maiki, maikiya, mikiya.

wag the head, to, v. (in token of assent) gyăda kai, also kăda kai; to w. or move the head (in token of dissent) kauda kai.

wage war, to, v. yin yaki.

wages, coll. lada, jinga, alāro, ijāra; one who pays w. mai- 
jinga ; to pay w. yin jinga, ijarta; a w.-earner dan ijāra, dan jinga.

wagtail, madikin ḳasa.

wail, n. kuka.

wail, v. kuka with $y i$ or the forms in $n a$.

waist, dunu.

wait, intr. v. gen. expressed by means of $j \check{m} a$, e.g. w. a little jima kădan, or jim kădan; w. a while sai anjima; to w. a short timejinjima; where the meaning is obvious tsaya (stop) is often used; to w. for jira, ǰrache, jirata, jiraya (S.), tsumaya (K.), yin jinkiri, dakata, dakanta, e.g. I waited for you na dakanta ma ku, yin dāko; to w., i.e. to linger dăde.

wait, lying in, n. fako, aranfaki, kwanto; a place for lying in w. mafaka.

wait, to lie in, intr. v. yin fako. waiting, dakachi, dāko, jinkiri, tsayi.

wake, to, intr. v. (to cease to sleep) falka; tr., to w. one up tada, tayas, falkad da.

wale, made by a whip etc., $\mathrm{n}$. kulu, pl. kulayi.

walk, n. (pathway) hanya, pl. hanyoyi; also tig. of the religious w., e.g. to follow the true w. bi hanyan gaskiya. walk, intr. v. (to move slowly on foot) yin yawo; this is used of the act of walking itself and of promenading, or taking a w.; very frequently in this sense the phr. shan iska (lit. to drink the wind) is combined with yawo or tafi, e.g. we walked for an airing muka yi yawo shan iska; to w. about zago; to w. backwards and forwards zago, jawagi* ; to w. on all fours rarrafe; to w. on tiptoe sanda; to w. proudly takama; to try to w. (to toddle) of infants dubbo dubbo.

walking, verbal n. yauwa; w. fast or excitedly gagawa; w. up and down in weaving wadari.

walking-stick, gwalma.

wall, n. katanga, garu, ringa (Z.), shirgiya, barza, e.g. if he comes out his wits are at the house wall (i.e. at home) idan ya fito hankalinsa da barza; the w. of a house built of mud bango, pl. ban gaye or banguna; the inner w. of a house kwasandi; a w. round a town ganwa; the grass covering of a w. to keep off rain boto.

wand, carried by officials, $n$. rukuke. 
wander, to, intr. v. ; fig. to w. from (to stray from) a path sau hanya or tafarki; to w. aimlessly shishigh

wanderer, landi*.

wandering, n. yauma; w. of aniunals matataki.

wane, intr. v. ragu, e.g. the day wanes (or is on the w.) rance ta ragu.

want, n. 1. (need, lack) rashi; w. of health rashin lafiya.

2. (penury) talauchi, see poverty ; v., to be in w. of rasa, e.g. he is not in w. of an excuse ba shi rasa huja ba. want, to, 1. (to be without) tr. v. rasa, kasa.

2. (to desire) so, e.g. I w. you to give me money ina so ka ba ni kurdi.

wanting, particip. (lacking, devoid of) prefix maras-, e.g. w. sense maras-hankali; w. strength maras-karifi; w. (in the sense of short) hilafa*.

wanton, n., see profligate. wantonness, n., see vice 1 . war, n. yaki, pl. yakuna or yakoki, gāba*, zaman; spec. a holy w. jihädi, jahādi; a civil w. bascesa; a proclamation of w. tăgara; a charm for protection in w. maganin yaki; a day fixed for w. ranar gamu; a large bird whose cry is considered an omen of war zakaran dawaki; v., to make or wage w. yin yaki; instruments of w. kayan dāya. warbler, grass w. purpur, sarikin kadi.

ward off, to, tr. v. tsc̆ra, tsări, tsăre, tsăro, tsărīma, kāre.

warm, to, tr. v. $z \bar{a} f a f a$; to $\mathrm{w}$. the hands yase hronnu; refl. to w. oneself at a fire, and intr. to become w. jin wutr; to w. up food drumama.

warm, adj. mai-dumi, see hot. warmth, dumi.

warn, tr. v. harbarta, kadarta, gargăda, also yalkadi with $y i$ or the forms in $n a$.

warning, n. galkadi, yaryadi, kashedi, habartawa*.

warrior, n. mayaki, gungama, jajirma*, zarumi, zarmi, pl. zarumaze or zarumai, $j a$ rimi*, sadauki, sha-bauje; fig. (lit. a large snake) gamsheka, gamshika; (lit. a black snake) mascusau* ; a boastful w. gugara*; a chief w. rago*; a strong w. gizgari*; w. without load, i.e. carrying only arms sunkuru* ; see soldier. wart-hog, alhanzir, hanzir, durungu.

wash, tr. v. wanke or wanka; in pregn. sense w. and bring back wanko; to w. over wivh 
water yafa, yafo; w. well kwala, kwara, wanke kalai. washed, pass. part. uankakke, fem. wankakka, pl. wankakku. washing, n., w. (ablution) alwalla.

washing, w. away zarni. wasp, n. zirnako, jinako, zinako, damafifito, rina; the mason w. zanzaro, zazaro (S.).

waste, n. 1. (destruction, harm, loss) barna, banna.

2. (wilderness) daji.

waste, tr. v. (to spoil, destroy) bāta, bătas, banna; to w. money (i.e. dissipate, squander) bätas (and kăshe) kurdidi; to lay w. yin kadaita. wasted, pass. part. batache, fem. batachiya, pl. batattu; v., to be w. (i.e. spent) bache, e.g. the ink is w. (i.e. dissipated, dried up) tadawa ta bache; (of man, with disease) yankwane, see emaciated. waster, raggo, see idle. watch, n. (time-piece) loto*, $s a^{6} a *$.

watch, v. tsăra, tsări, tsăre, tsc̆ro and tsc̆rìma, kŭlo, yin shigoro, zura ido; to w. carefully duba, dubo; to w. cattle kiwo.

watching, shigoro. watch-tower, mab̆gya (S.). water, n. ruwa, pl. ruwaye, ruwaiwai; cold w. ruwan sanyi; hot w. ruwan zafi, ruwan dumi; drinking w. ruwan sha; rain w. ruwan Allah or ruwan sama; a sip of w. guwa; a beam for drawing w. jigo, pl. jiguna, kutara*; splash of w. funjum, bundum-bundum ; v., to draw w. jan ruwa, kwalfa, dèbe and tèbo ruwa, dauka ruwa; pure w. Kuna ruwa; to make w. yin fitsari, boli; muddy w. gurbatachen ruwa; w. which wells slowly up ruuan jura; still w. kurıma; the sound of running $w$. kur-kur-kur, war-war-war.

water, to (i.e. to give to drink) shäida.

water-buck, ambeche, dodōka, yakumba, gwambaza.

water-cress, lafuwa.

water-fowl, a black w.-f. $d i$ milmilo, dumulmuli (S.).

watering, shadawa. water-lily, bădo, ḳola (S.). water-pot, n. tulu, pl. tuluna; spec. pumpkin or gourd from which w.-pots are made düma, pl. dumaimai, dumame, gyandama, jallo (K.).

waterproof, riyar ruwa.

waterside, n. (watering-place) mashaya.

waterspout, indararo (S.). 
watery, adj. da ruwa.

wattles of a cock, n. lebatu, laibatu.

wave, tr. v. (to move to and fro) yin shillo, reto; she is waving her kerchief tana gilgiza kallabinta.

waves, $\mathbf{n}$., of water rakumman mus; heat $\mathrm{w}$. in the air diyal rana.

waving, shillo.

wax, n. gabduwa* (from the ear) daudan kunne; see beeswax.

wax-bill, (bird) asisi, baiwar Allah.

way, n. (road and also fig. of religion, etc.) hanya, pl. hareyoyi, tafarki, pl. tafarkoki, bübe, turba, p!. turbobi; (of temper, character) hali, pl. halai, e.g. that is his w. halinsa ke nan; in this w. hakanga, see thus; v., to go out of the w. (to make room for) ratse; to lose the $\mathrm{w}$. ratsa (or ratse) hanya, karkache; to build or construct a w. gina hanya and gen. to prepare a w. gyara hanya; phr. I know my w. about na sani duniya.

we, pers. pron. nominative sep., e.g. all we or we all mu duka; we two mu biyu; prefixed to past tenses, e.g. we saw him mun gan shi; suffixed to auxiliary of the future and to the passives, e.g. we will go together za mu tare; we were driven out aka fitas da mu. weak, adj. rashin karifi, maraskarifi, babu karifi, kumāma, raunana, dagogo (Kats.).

weakness, n. kumamanchi, ramni.

wealth, n. gatanchi, tajivchi, see property, riches. wealthy, adj., see rich 1. wean, tr. v. yin yaye. weapon, mahalbiyi, see arms. wear, tr. v. sa* (lit. put on)

used with riga etc.

weariness, n. yajiya, gajewa, gajiyawa, angaje.

weary, adj. da grăjiya; v., to feel w. jin yăjiya.

weather, fine, n. duniyg dadi; it will be fair w. $\approx a a y i$ sarari; the w. is bad to-day yau ba sarari ba.

weave, v. saka; a frame used in weaving through which the warp threads pass after leaving the allera, masefi.

weaver, n. ag. masaki, ma. saka; weaver's loom takala; weaver's shuttle masaka.

weaver-bird, the yellow w.-b. jira; the Jong-tailed w.-b. (Vidua principalis) zulaidu, zulaidi, sometimes called 
sarikin tsuntsaye; the blackheaded yellow w.-b. kābare; the black-headed w. finch shaida.

weaving, sâka; to walk up and down for purposes of w. wadari; the pulley on a loom on which the peddles work chikalkora; the wooden board to which the unwoven thread of the warp is fastened kunkuru; the revolving cage on which the spun yarn is wound before w. yaro-ba-kiwuya.

web, spider's, n. sumya, shanshando (S.).

wedding, n., see marriage; w. festivities amarchi.

Wednesday, n. ranal laraba, laraba, larba.

weed, tr. v. yin tsintsuwan chiyawa.

week, this day w. yăda yau : to-morrow w. yăda gobe.

weep, intr. v. yin hawaye; seè cry.

weevil, a small w. which eats corn kun-ki $i$-chi*.

weigh, tr. v. auna, auni, awuna, yin awo, guada; actions are weighed ayuka awonsu.

weighing, verbal n., anything for w. with abin awo; anything used for w. ma-auna. weight, n. 1. (measured heaviness) awo; for particular measures of w. see miskal, rotal ${ }^{*}$; v., to feel in order to discover the $w$. of a thing jinjini; giving short w. $t s \alpha-$ kure.

2. (heaviness) nauyi, nau$w a^{*}$.

weighty, adj. (heavy) da nauyi.

welcome, interj. used as a salutation on meeting after a long time marhaba, măraba, barka da zuwa, barka da yini; see also under sanu.

welcome, tr. v. (to receive as a guest) shide, marhabshe, tarairaiya, tarba, tarbi.

well, n. rijiya, pl. riyoji or rijiyoyi; a deep w. rijiya $d a$ zurfi, tuimniya; spec. a beam for drawing water out of a w. jigo, pl. jiguna; v., to dig a w. gina rijiya; falling in of a w. burma.

well, to w. out tsatsăfa.

well, adj. 1. (right, proper, advantageous) da kyau.

2. (in good health) $d a$ lafiya and lafiya, e.g. are you w.? kana lafiya? quite w. sai lafiya or lafiya lau; he came back here w. ya komo lafiya; to be w. yin lafiya.

3. adverbial expressions 
are: (of approbation) w. $d a$ kyau; (of doubt, hesitation) w.! to, aya, aiya; as w. as (together with) tare $d a$; w. then (introducing a statement) dăga nan.

west, n. yamma, mayariba. westward, adv. yammachi. wet, n. (rain) ruwa; cf. seq. wet, to be, intr. v. (of the weather) e.g. it is w. ana ruua; it was very w. an yi ruwa dayawa; (to become wet) jiki; (to be wetted or put in water) a jika tsantsama, suma (S.); to be very w. juḳa sharkap.

wet-season, n. damăna or damuna; to pass the w.-s. yin damăna; see under rainy.

what, pron. 1. dependent relative (that which) abin da, e.g. I see what you want na gani abin da ka ke so.

2. interrog. what? mi, me, mine and minene, e.g. what has happened to you? mi ya same ka? what shall we do? $m i z a$ mu yi? also adj. $w a$, wanene, fem. wache, wacheche, pl. suvo, suwane and surcenene, e.g. what is his name? wa sunansa? what kind of bird is this? uanne irin tsuntsuwa ke nan? see under who. whatever, indef. rel. pron. komi, e.g. whatever begins will come to an end komi ya faru za shi shi kare ne.

whatsoever, indef. rel. pron. komine, e.g. wh. you do, it will be of no use komine $k a$ yi babu anfani.

wheat, n. alkama; w. in good condition alkama tsari; tuft of w. geza, pl. gezuna; ear of w. kube, see ear.

wheel, n. rumbuwa*, vjala*, keke.

whelp, n. kwikuyo or kurkwiyo, pl. kwikuye.

when, adv. 1. rel. $d \alpha$, yanda, yawanda, yaushe, saban da, lokachin da, ran da, kagada (S.), idan or izan, kădan, kan, kamin, kur* or kul*.

2. interrog. when? yaushe, wache sa'a, wanne lokachi; since wh.? tun yaushe, dăga yaushe; until wh.? har yaushe? whence? dăga ina?

whenever, adv. ko yaushe, e.g. wh. he gets up he falls down again ko yaushe shi tashi ya fodi kumu.

where, adv. 1. rel. inda, wurin $d a$.

2. interrog. where? ina? wherefore? adv. domi? dommi or domin $m i$ ? see why. wherever, adv. kö̈na. 
whether...or, correlatives yalla...ko, ko...ko.

which, see who.

while, a little, n. jima kadan and $j i m$ kadan.

while, adv. rel. tun da, e.g. while they were speaking together I ran off tun $d a$ suna yin magana na tafi da gudu; wh. they were about to kill him a wonderful thing happened tun $d a z a$ su $k a$ she shi abin mamaki ya faru. whip, n. (of skin) kurfu, pl. kurafu, bulala, pl. bulalai.

whip, tr. v. yin bulala, yin kurfu, e.g. he whipped them ya yi ma su bulala.

whirling, n. juyi.

whirlwind, n. guguwa, used esp. for dust storm.

whiskers, saje, pl. sajoji; w. and moustache washefe.

whisper, intr. v. rada, chimbaya, both esp. in bad sense. whisperer, n. ag. mai-rada. whispering, n. rada. whistle, n., made of horn kwabura (K.), kwabira (S.). whistle, intr. v. (with the lips) yin fèto, yin fìto.

whistling, participial n. $f \bar{e}-$ duwa, fito, feto, shewa.

white, adj. fări, fem. făra, farfara, pl. fărare, făru-făru or farfaru; very wh. fări fat; a wh. (i.e. one of a wh. race) ba-ture.

whiten, to faranta.

whitened, pass. particip. făraya, pl. fărayu.

whitish, (i.e. dirty white) fori fari.

who, pron. 1. rel. (also which, the objective whom, and the rel. that) wanda, fem. wadda, pl. wadlanda, also simply $d a$; the possess. whose is expressed by the foregoing with the corresponding possess. pron. suffixed to the object possessed, e.g. the man whose camel I killed mutum wanda na kashe rakuminsa.

2. pronominal interrogative who? (also = which ?) $w \alpha$, wane and wanene, fem. wache, wacheche, pl. suwa, suwane, e.g. who is this? wa ke nan; who are you? wanene kai; which are they? suwane ne; which of them? wane chikin su; which woman among them? wache chikin su; who is this? wanene wannan; the possess. whose? is expressed by placing the name of the object possessed in the connective before the interrog., e.g. whose daughter art thou? (i.e. who is thy mother?) diyar wacheche ki ke; whose son is 
he? dan wa shi ke; whose horse is this? dokin wa kenan.

3 . the adjectival interrogative forms are wanne, fem. wache, pl.wădanne; who is he? wanne shi; what woman is it that has come? wache mache che wannan wadda ta zo; what men are these? wadanne mutane ke nan.

whoever, indef. pron. kowa, duka wannan $d a$; see soever. whole, n. dukachi, dukanta, e.g. the w. of mankind $d o-$ kachin mutane.

whom, rel. and interrog. pron., see who.

whore, n. shakaliya, pl. shakalai, karuwa.

whoredom, n. shakalchi, karuwanchi.

whose, possess. rel. and interrog. pron., see who.

why, dependent rel. adv. domi, dommi, don mi, domin mi, he did not tell us why he did this thing $b a$ ya fadi ma mu domi ya yi abin nan; interrog. why? domi, dommi or domin mi, sabilin mi, mi ya sa, sabad da mi.

wick, n., lamp w. made of twisted cotton lagwami, lagwari.

wicked, adj. mugu, fem. mugunya, pl. miyagu; a w. person mugun mutum, malalachi.

wickedness, n. mugunta, lābo, shegantaka.

wide, adj. da fādi, maifadi, bikiki, da faski; n., a w. place yalwa ; it is two cubits w. fadinsa (=its width) kamu biyu.

wide-opened, adj.kurkurkur*. widow, n. zauwara, zaura, gwabruwa, jaura, bazawara, gwamruwa, pl. gwamraye; a w. during her time of retreat tăkaba.

widower, gwabro, gwauro, gwamro, jauri, zauri.

widow-finch, zulaidu. widowhood, zauwarchi.

width, n. fadi, faski, e.g. its w. is this fadinsa ke nan.

wife, n. mata, pl. mataye; spec. chief w. uwar gida or uwal gidu; w. of a polygamist kishiya (q.v.), pl. kishiyoyi; a favourite w. mowa. wild, adj., see tame 1 . wilderness, n. daji, dăwa, see desert.

wile, n., see stratagem. will, n. 1. (assent, consentand so, permission) yarda, (pleasure, wish, determination) turn, e.g. work your w. ku yi abin da ku ke so.

2. (testament) wasich $i *$ 
will, v. 1. (of consent, also willingness) yarda.

2. as auxiliary of the fut. $z a$, e.g. I w. run $z a n i$ gudu; he w. return here za shi komo. willow, rimni, ba ruwana. win, v. (in gambling) kasa, chi, e.g. I w. na chi.

wind, n. iska or hiska, pl. iskoki or hiskoki, holoko*; a dusty w. malalo ; the Harmattan w. iskan buda; the w. is now blowing hard iska yana busawa yanzu da karifi; to break w. yin tusa.

wind, tr. v.murda, murde (K.), mirda, mirde (S.) ; to w. thread wadarta; intr. (to coil) nade.

winding-sheet, n. likafani, likkafani.

window, n. (i.e. a hole to look out) sakata, taga (K.), pl. tagaigai; dan kofa.

wind-pipe, n. muriya, pl. muriyoyi, janai, janyaro. wine, palm-, n. bam, bami. wing, n. (of bird) fifike, fikafike, pl. fikafikai, fukafuki, pl. fukafukai, faifeto, fefeto; w. of an insect kallemu (K.); flapping of w. fuffuka, pupuka.

winged, adj. mai-fefeto.

wink, v. kyabta (or kyapta) ido, jafache, rumtsa; to w. with one eye yin kanne. winking, participial n. kyabtawa, kyaptawa, kanne.

winnow, v. tankada and yin tankade, bakache, sheka, shi$k a$.

winnower, n. ag. mai-bakache, mashekiya*.

winnowing, tankade.

winter-season, $b \bar{u} d a$.

wipe, tr. v. shafe, karta (K.), karche (S.), katse; wiping (e.g. of a dish) katsa; anything used for wiping abin shafe.

wisdom, n. 1. (sagacious insight) lura, budi, hikima*.

2. (prudence, good sense) hankali.

wise, adj. in sense of prec. 1 . mai-lura; in that of prec. 2. da hankali.

wish, n. abin so, fata ; a strong w. guri*; unless I w. sai na ga dama.

wish, tr. v. so, nufe or nifa; to w. for fache; to w. rather $f i$ so, e.g. I w. this rather than that na fi so wannon da wanchan.

wit, cf. I am at my wits' end dabara ta kare.

witchcraft, n., see sorcery. with, prep. 1. instrumental, $d a$, e.g. they slashed him w. a sword suka sare shi da takobi. 
2. comitative, de which is commonly used with verbs of motion, e.g. go off $w$. it (take it away) tafi da shi; (in company w.) tare $d a$; (near, by) wuri na or wurin, gun, e.g. w. the king vouri ne (or wurin) sariki; thou must seek knowledge w. the Mallams kai dai a nemi shivi gun mallamai ; (of competition and contest) $d a$, e.g. he fought $w$. a certain man ya yi fada da vani mutum; he made war w. Kaffi ya yi yaki da Kafi.

withdraw, tr. v. kauda, kaushe, turje, turjo; to w. the hand danko; intr, to w. from (to move away from) gusa, yulgusa or gurgusa, toge ma, kude (S.); to w. into shelter noke.

wither, v. yaushi, tsotse and tsotsi, kuvake*; (of plants) yankwane.

withered, pass. part. shanyayye, fem. shanyayya, shanyаyуu ; spec. w. branches kuvabruka; w. tree koren itcule.

withering, n. yaushi. withhold, tr. v. hana. within, prep. chǔkin or dăga chǐkin, tsakan*; from w. dăga chı̌kin. without, prep. 1. (devoid of, wanting) $b a$, babu, bamda, e.g. w. doubt babu shakka, babu wawa; with the prefix maras-compounds are formed equivalent to the English prepositional phrase, e.g. w. shame marcs-kumya; v., to be w. rasa, tafe, tafi, tabe, kasa.

2. (not within) see outside.

witness, n. 1. (testimony) shaida, pl. shaidri and shaidodi; eye-w. shaidar ido; false w. shaidar zur.

2. (a person who testifies) mai-shaida, pl. masu-shaida; v., to bear w. shaida with $y i$ or the forms in $n a$; to bring or adduce w. kai (or kawo) shaida; to bear false w. damre magana.

wizard, n. maye or mayi, fem. mayya, boka, pl. bokaye.

woe! interj. wai, tir, e.g. w. is me! wai niya; w. unto you! tir da ku; see alas.

wolf, an animal resembling a w. (the hunting dog), n. kyarkechi, kyalkechi, kirikinji, kilikinji.

woman, n. mache, pl. mata, mutumniya; young w. yarinya, pl. yammata; a bad w. karuwa, shakaliya; a w. 
without a husband bazawara; a woman's loin-cloth fatari ; an old w. gyatuma, gome, yakumbre.

womanliness, wanchi.

wonder, n. 1. (the feeling) woba*.

2. (something wonderful, a w.) mamaki and abine mamaki, ajaba, ajub, karāma.

wonder, intr. v. yin wola, jin mamaki, saurara*.

wonderful, adj. da mamaki. wont, n. (= habit) tada, ada, e.g. this is their w. $t a-$ darsu ke ran; v., to be w., see accustom 2.

wood, n. 1. (forest) rukuki.

2 . (the material of trees) itache and iche; a little piece of w. dan itache; spec. a long piece of $w$. tied behind the ear as a punishment for thieving kangalai.

woodpecker, green makokofo, makokofi.

wool, n. mulufi or malufi, ulu, sufi, rero*.

woollen, adj. da (or na) mulufi or malufi; woollen cloth mulufi or malufi.

word, n. magana, pl. maganyamu, zanche, pl. zantatuka, kalma, kalami*, karātu; pleasant words (lit. ear broth) romon kunne. work, n. (employment, business, labour) aiki, shăyali, shugala*, pl. shagulgula, tsur$f a$; concr. (a production, an act, a w.) aiki, pl. aikoki; net-work aikin raya; a bad w. aiki mugu; a day's w. wunin aiki; v., to refuse to w. or to shirk w. ki wuya, huji; to start w. kama aiki. work, intr. v. aiki with yi and the forms in $n a$; to w. diligently yin sawabe; to w. uselessly. sunkwiya or sunkuya; n. unwillingness to $\mathrm{w}$. sassauchi.

working, n. (action, operative power) $y i *$ q.v.

workman, n. ag. maaikachi, pl. macikata.

workshop, n. maaikachi*. world, n. duniya; the next w. lahira, yidan gobe. worm, n., an earth-w. tana, pl. tamu, tsutsa; earth-worms abin kăsa; thread-w. kuaraba; tape-w. tsilla; guinea-w. kurkunu, girgamu; worms in horses or asses coll. čzumaki, ăzurmaki.

worry, tr. v. wahalshe, dāme; he worried people beyond endurance ya chika dama mutane.

worse, comp. adj. mafi mugunta daga. 
worship, n. (religion, creed) addini*; (divine service) salla; Mohammedan w..musulumchi.

worth, (deserts) chinchinta.

worthless, adj. banza, la'ane, fern. la'ana, pl. la'anu, lalatache, fem. lalatachiya, pl. lalatattu, amere, wofi, yofi (S.) ; n., a w. fellow !lan banza, wofin mutum; to be w. lalache, tunkushe.

worthy, adj. kirki, kiriki.

wound, n. rauni, makami, miki; scar of a healed w. tabo, tambo.

wound, tr. v. rauni; to w. with a spear chăke.

wounded, pass. part. da rauni. wounding, jinaya.

woven, pass. part. sakakke, fem. sakakkiya, pl. sakaḳku.

wrap, tr. v. yafa, yafo, sunke, kunshe*.

wrapper, n. (goatskin loin w.) walki (S.), warki (K.).

wrapping, grass, for packing salt, etc., n. burdumi.

wrath, n., see anger. wrestle, intr. v. yin kokuwa. wrestler, n. mai-kunche. wrestling, n. kokuwa, kokowa; a. w. game gumaza.

wring, tr. v. murda, e.g. they wrung the fowls' necks suka murda wuyan kaji. wrinkled, to be takura. wrinkling, n. yaushi, yoshi. wrist, n. wuyan hannu, tsintsiyar hannu; w.-bone idone hannu; spec. a w. ornament worn by the heathen warami, pl. waramai; a wristlet made of leather and wood cläya; w. bangles kărau, kambu, kambuwa, warami.

write, v. rubuta, rubutu, yin rubutu, rubuche.

writer, marubuchi, pl. marubuta.

writing, n. abstr. rubutu or rubuchi; a w. board allo; concr. (anything written, a w.) laya, pl. lawaye, layu, takarda, pl. takardu, mbutu, mubuchi, litafi, pl. litattafi, litatafai; a line of $w$. shaIrera, shatsc̆ra; spec. writing from God (used of the Koran, the Psalms or Gospels) $z a$ bura*.

wrong, n. (violation of right) laifi; v., to do w. yin laifi, karkache, e.g. he did me w. ya yi ma nilaifi; I will produce proof so that anyone may see that you are in the w. ni kawo shaida kovea shi gani ku ke da laifi.

yam, n. doya, pl. doyoyi, maguraza; a $\mathrm{y}$. cooked and 
beaten up sakucura: kokó y. gxaza; a kind of $y$. (the. Kaffir potato) rizga; a root resembling a y. tumuku, chakara.

yard, (measure of length) san$d a *$.

yarn, (thick cotton) n. abäwa. yawn, intr. v. $m i k a^{*}$; he does nothing but y. saishina mika. yaws, kyambi (S.).

ye, pers. pron., see you. yea, adv., see yes.

year, n. shekara, pl. shekaru, e.g. how many years old are you? shekarunka nawa or shekara nawa kana da rai or shekara nawa tun haifuvalka; last y., adv. bara, bariya; next y. badi; this y. b̆na; v., to live (so many) years shekara; y. after $\mathrm{y}$. shekara da shekuru.

yeast, n., spec. y. made of acid pulp of the tamarind tsamiya. yellow, adj. rawaya, pl. rau $y u$, spec. y. needlew bernouse yar-rani.

yes, adv. i, na'am, mādalla*, yau*, yo*; to say y. (to assent or consent) kada kai; see certainly.

yesterday, n. jiyc; the day before y. shekaranjiya, three days ago wanshekaranjiya; y. evening jiya da mareche. yet, adv. har yanzu, e.g. is your father y. living? ubanka har yanzu shina da rai; while $\mathrm{y}$. tun da, e.g. while they were y. running tun da suna gudu; not y. tukun, tukuna with $b a$, e.g. he has not $y$. gone away ba ya tafi tukuna ba; $I$ have not $y$. found it ban samu har yau.

yoke, put on necks of slaves, n. karkiya.

yokel, a bagidaje, dan kauye. yolk of egg, n. gwabduwa, guanduwa.

yonder, 1. dem. adj. (also=the one y.) wanchan, fem. wachan, pl. wadannan, chan or cleana, e.g. on the y. side dăga waje chan.

2. adv. (over there) chan, chana, dăga chan, wuri chan. Yoruba people, Hausa name for ayagi, Yaribawa.

you, pers. pron. (also ye) $k u$; to you $m a k u$ or with assimilation muku.

young, adj. 1. (new, fresh, not used of animals or men) sībo, fem. sābuwa, pl. sabui, sabobi, sababi or sabbi.

2. (of animals) $d a$, conn. dan, fem. diya, pl. ya, conn. yan, coll. diya, e.g. a y. lion dan zaki or dan zakanya; y. lions yan zakanya; the 
hyena brought forth her $\mathrm{y}$. kura ta haife diyanta.

3. (of human beings) special terms are used requiring no adj., e.g. a y. lad yaro, pl. yare; a $\mathrm{y}$. woman yarinya, $\mathrm{pl}$ yammata; a y. man, see youth. youngest, adj. auta. youngling, n. (of animals) kwikuyo, labubu, kurkwiyo, kuyikuyu, pl. kwikuye, kuyikuyai.

your, possess. pron. suffixed to a masc. n. $-n k u$, suffixed to a fem. n. $-r k u,-l k u$, e.g. y. king sarikinku; separate, if the object possessed is masc. naku, if fem. taku, if $\mathrm{pl}$. naku.

yours, (the form of prec. employed when the object possessed is not expressly stated but implied) with masc. object naku, fem. taku, pl. naku, e.g. our horses are
- better than y. dewakirmm sun fi naku.

yourself, yourselves, refl. and emphatic pron.; see self. youth, n. 1. abstr. yaranteka, yarinta.

2. concr. (a y. from fourteen to twenty years of age) samrayi, saurayi, sarmayi, pl. samari.

Zaria, the town, Zazzau, Zozo or Zakazak; the people of Z. Zagezagi.

zeal, n. himma, harama, hazama, yaji*; v., to show z. maida (or yin) himma.

zigzagging, kurda nan kurda nan.

zithern, a kind of garaiya, guraiya, karaiya.

zizyphus, n., Z. spina Christi kurna; Z. lotus magariya; Z. mucronata (buffalo-horn) magariyar kura. 


\section{Cambrioge:}

PRINTED BY JOHN CLAY, M.A. AT. THE UNIVERSITY PRESE 


\section{UNIVERSITY PRESS RELATING TO AFRICA}

A History of the Colonization of Africa by Alien Races. By Sir Harry H. Johnstos, G.C.M.G., K.C.B., Hon. Sc.D. Cantab. New Edition, revised throughout and considerably enlarged. Crown 8 vo.

With 8 maps. $8 s$. net. Cambridge Historical Series.

Ethnology of A-Kamba and other East African tribes. By C. W. Hobley, C.M.G., A. M. Inst. C. E. Demy 8ro. With 54 illustrations and a map. $7 s$. 6 d. net.

The Tribes of Northern and Central Kordofán. By H. A. MacMrchael, Sudan Civil Service, late Scholar of Magdalene College, Cambridge. Demy 8vo. With 19 plates. 1os. 6a. net.

Brands used by the Chief Camel-owning Tribes of Kordofán. By the same author. Demy 8 ro. With iz plates. 6s. net. Initia Amharica. An Introduction to spoken Amharic. By

C. H. Armbruster, M.A., Sudan Civil Service. Royal 8 ro.

Part I. Grammar. i $2 s$. net.

Part II. English-Amharic Vocabulary with phrases. 1 ss. net.

Vocabularies of the Kamba and Kikuyu Languages of East Africa. By Hildegarde Hinde (Mirs Sidney L. Hinde). Crown 8vo. 3s. net.

The Masai Language. Grammatical Notes, together with a Vocabulary. Compiled by Hildegarde Hinde. Crown 8 vo. $3 s .6 d$.

A Grammar of the Somali Language with Examples in Prose and Verse. And an account of the Yibir and Midgan Dialects. By J. W. C. KIrk, B.A., King's College, Cambridge, Lieutenant, Duke of Cornwall's Light Infantry and 6th (Somaliland) Battalion, King's African Rifles. Demy 8vo. 7 s. 6 d. net.

The Modern Egyptian Dialect of Arabic. A Grammar, with Exercises, Reading Lessons and Glossaries, from the German of Dr K. Vollers. With numerous additions by the Author. Translated by F. C. Burkitt, M.A. Crown 8vo. ios. 6d.

Dictionary of the Hausa Language. By the Rev. Charles HENRY Robinsox, D.D., sometime Lecturer in Hausa in the University of Cambridge, Honorary Canon of Ripon. Crown 8vo.

Vol. I. Hausa-English. Third edition, revised and enlarged. I2s. net.

Vol. II. English-Hausa. Third edition. 9s. net.

Specimens of Hausa Literature. By the Rev. Charles Henry Robinson, M.A. Small 4 to. Ios. Translation, Transliteration and Notes, without Facsimiles, $s$ s.

\section{Cambridge University Press \\ C. F. Clar, Manager \\ London: Fetter Lane, E.C. \\ Edinburgh : 100, Princes Street}





PLEASE do Not ReMOVE

CARDS OR SLIPS FROM THIS POCKET

\section{UNIVERSITY OF TORONTO LIBRARY}


